Universidade de São Paulo

Escola Superior de Agricultura "Luiz de Queiroz"

Capital empresarial: um estudo de caso para o agronegócio

Sheila Cristina Ferreira Leite

Tese apresentada para obtenção do título de Doutor em

Ciências. Área de concentração: Economia Aplicada

Piracicaba

2008 
Sheila Cristina Ferreira Leite

Bacharel em Ciências Econômicas

\section{Capital empresarial: um estudo de caso para o agronégocio}

Orientador:

Prof. Dr. FERNANDO CURI PERES

Tese apresentada para obtenção do título de Doutor em

Ciências. Área de concentração: Economia Aplicada

Piracicaba

2008 


\section{Dados Internacionais de Catalogação na Publicação (CIP)}

DIVISÃO DE BIBLIOTECA E DOCUMENTAÇÃO - ESALQ/USP

Leite, Sheila Cristina Ferreira

Capital empresarial: um estudo de caso para o agronegócio / Sheila Cristina Ferreira Leite.- - Piracicaba, 2008.

191 p. : il.

Tese (Doutorado) - - Escola Superior de Agricultura Luiz de Queiroz, 2008.

Bibliografia.

1. Agribusiness 2. Capital - Economia 3. Desenvolvimento econômico

4. Empreendedorismo 5. Estudantes universitários I. Título

CDD 332.041

"Permitida a cópia total ou parcial deste documento, desde que citada a fonte - O autor" 
Aos meus pais

DEDICO 


\section{AGRADECIMENTOS}

Ao decorrer de nossa vida vamos descobrindo o valor de agradecer, e ao findar uma etapa como esta, gostaria de deixar os meus sinceros agradecimentos a todos àqueles que me estimularam e colaboraram para que esta tese fosse realizada

Ao professor Fernando Curi Peres, meu orientador, pela tolerância, pelo dinamismo, pelos comentários, sugestões e críticas e pela seriedade e rigor acadêmico.

À todos os demais professores do Departamento de Economia, Administração e Sociologia da Escola Superior de Agricultura “Luiz de Queiroz”, pelos ensinamentos que deles recebi.

Aos funcionários não-docentes do Departamento de Economia, Administração e Sociologia, em especial, Maielli.

Aos pesquisadores do Max Planck Institute of Economics, especialmente Dr. Werner Bönte, Dr. Erik Monsen, Dr. Andrea Conte e Dr. Stephan Heblich, pela inestimável e prestimosa colaboração.

As secretárias Lídia Nobis e Madeleine Schmidt do "Entrepreurship, Growth and Public Police Group” do Max Planck Institute of Economics por toda atenção dispensada durante o período do doutorado sanduíche.

Ao pesquisador Dr. Ron H. M. Bergevoet, pelo seu esforço em colaborar para a execução deste trabalho.

À todos os colegas e amigos, em especial, Margarida, Euro, Rosane, José Geraldo, Sandra e Maurício, pela colaboração, pelo apoio, pela preocupação e pela amizade.

À Deus. 


\section{SUMÁRIO}

RESUMO

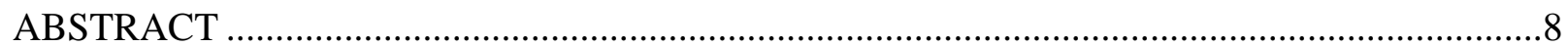

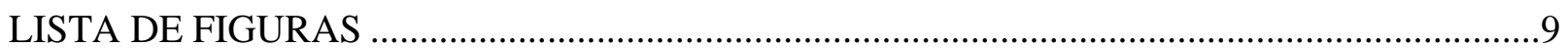

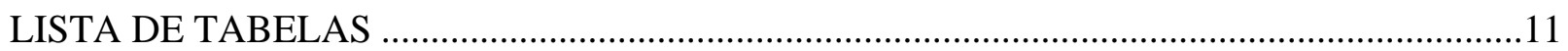

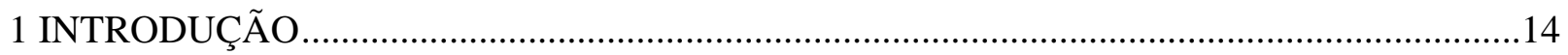

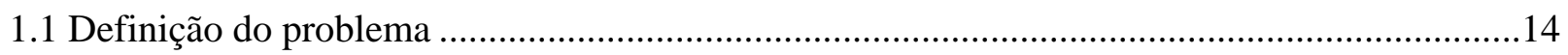

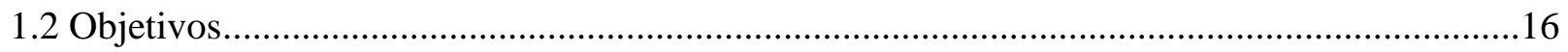

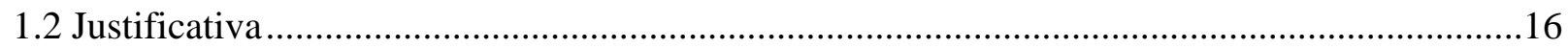

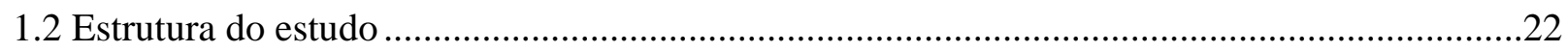

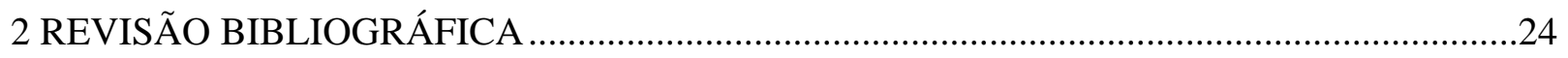

2.1 Fatores de produção....................................................................................24

2.2 Empresário na economia .......................................................................................25

$2.3 \mathrm{O}$ estoque do fator de produção empresário: capital empresarial.........................................30

2.4 Correntes que explicam a oferta de capital empresarial ...................................................34

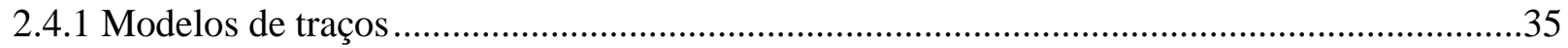

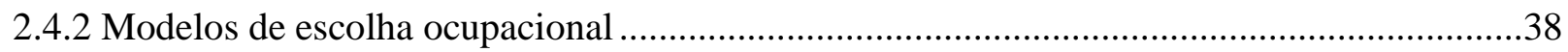

2.4.3 Modelos ambiente-característica dos indivíduos.......................................................45

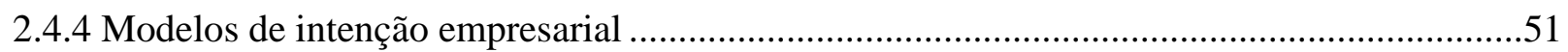

2.4.5 Modelo fundamentado na teoria sócio-cognitiva da carreira ...........................................55

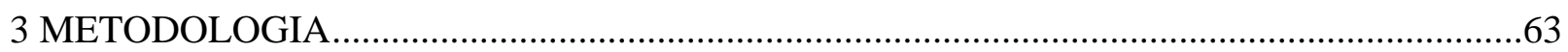

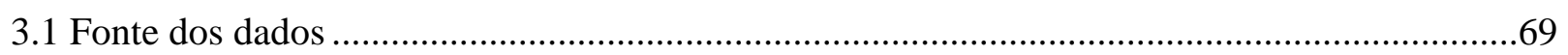

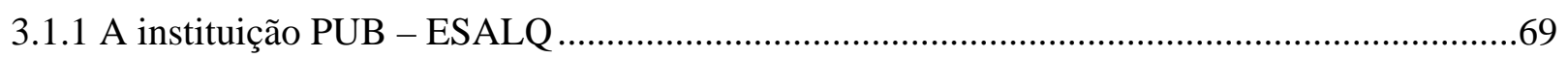

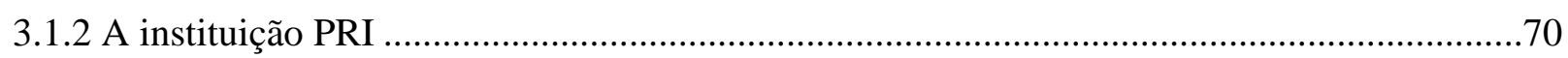

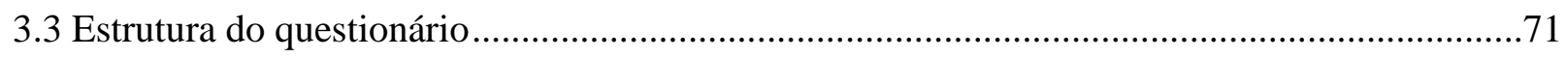

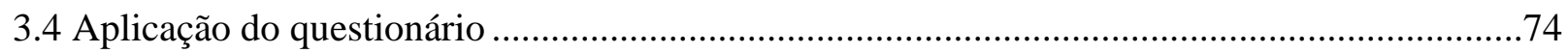

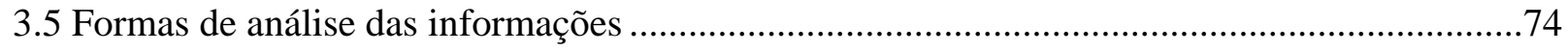

3.6 Caracterização da amostra e Análise estatística dos dados ..............................................75

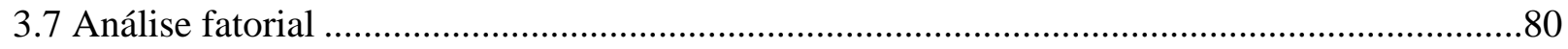

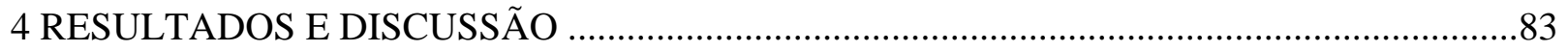

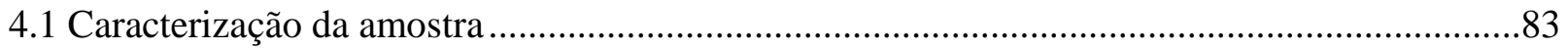




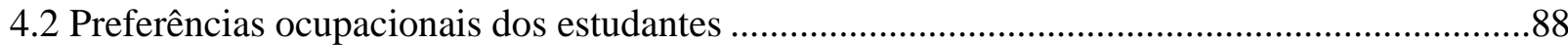

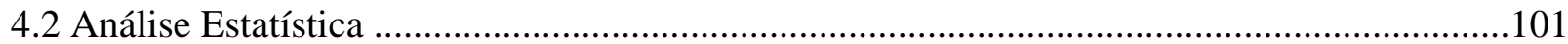

4.2.1 Análise Estatística da amostra de estudantes ingressantes ..............................................102

4.2.2 Análise Estatística da amostra de estudantes formandos.....................................................125

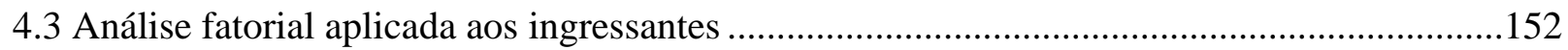

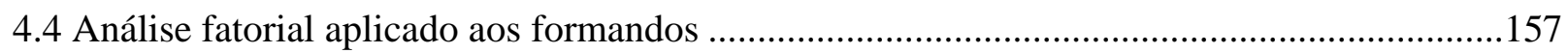

4.5 Empecilhos Contextuais e Expectativas e Facilitadores no curso superior para desempenhar

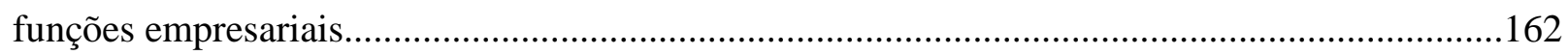

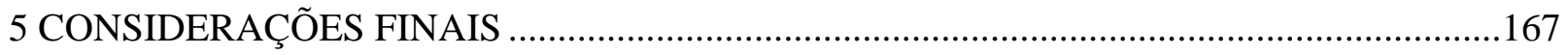

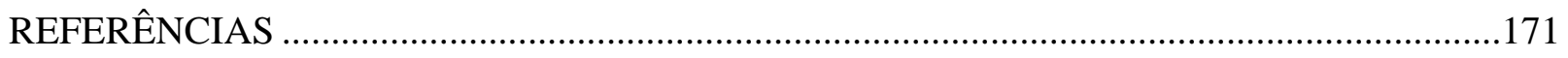

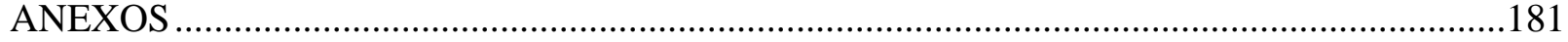




\section{RESUMO}

\section{Capital empresarial: um estudo de caso para o agronegócio}

As discussões econômicas em geral não incluem os empresários, entretanto, este agente é de suma importância para o crescimento e desenvolvimento econômico. Com a aceleração do processo de globalização tende-se a aumentar a demanda por empresários em detrimento da demanda por funcionários. Este trabalho tem como objetivo identificar a existência de um conjunto de características que expliquem o gosto e/ou a intenção de ser empresário versus funcionário entre estudantes que iniciam e terminam seu curso em nível superior. Identifica-se através de um estudo de caso se a educação em nível superior estimula ou não na formação do desejo e da intenção de se tornar empresário. As escolas que compõem o estudo de caso são a Escola Superior de Agricultura "Luiz de Queiroz"- ESALQ e outra escola identificada neste trabalho como PRI. Os dados do trabalho são de fonte primária e foram coletados por meio de 493 questionários aplicados válidos aos estudantes ingressantes e formandos de ambas as escolas. Considerando-se que gosto e intenção são variáveis dependentes e que a primeira estimula a segunda, o questionário foi construído de forma que gosto e intenção sejam variáveis-chave para se entender a formação do estoque de empresários. Definiu-se que os alunos pertencem a três perfis ocupacionais excludentes: funcionário da iniciativa privada, funcionário público e empresário. A identificação do efeito educação é defendida com base no confronto das freqüências das respostas dos estudantes ingressantes e formandos quanto ao seu gosto e sua intenção em desempenhar os perfis ocupacionais considerados. A aplicação do teste de quiquadrado garantiu que as diferenças encontradas nas respostas dos alunos ingressantes e formandos sejam estatisticamente significantes, podendo-se assim inferir o efeito das instituições na formação do desejo e da intenção de atuar como empresário e demais perfis considerados. Outros testes estatísticos não-paramétricos foram realizados com a finalidade de se conhecer os determinantes dos perfis ocupacionais. Ainda, a aplicação da análise fatorial permitiu determinar quais fatores têm maior importância para a formação do desejo dos estudantes ingressantes e formandos por uma ocupação profissional. Como principal resultado encontrado tem-se que as instituições estimulam a formação de desejo e de intenção de ser empresários. Na ESALQ, comparando-se alunos ingressantes e formandos, observa-se que há um aumento do grupo de alunos com gosto e intenção de atuar como empresários. No entanto, dentre eles, verifica-se que há uma parcela dos estudantes formandos que gostariam de ser empresários, mas não têm intenção de atuar como empresários. Possivelmente este resultado deve-se ao fato de a ESALQ treinar seus alunos para serem funcionários da iniciativa privada. Está hipótese é confirmada pela diferença do percentual de formandos com gosto e com intenção de ser funcionários da iniciativa privada. Os formandos da escola PRI não apresentam este comportamento, sendo que o grupo com intenção de atuar como empresário é maior que o grupo com gosto por atividades empresariais.

Palavras-chave: Gosto empresarial; Intenção empresarial; Escolha ocupacional; Educação e escolha ocupacional; Ensino superior e empresários 


\section{ABSTRACT \\ Entrepreneurial capital: a case study for agribusiness}

In general, economic discussions do not consider the existence of entrepreneurs; however, this agent is important for the growth and economical development. Due to the globalization process acceleration there is tendency to increase the demand for entrepreneurs in detriment to demand for employees. The main objective of this study is to identify the existence of characteristics that explain the desire and/or the intention to become either entrepreneur or employee among freshman and near-completion student groups so that a case study could evaluate if undergraduate education stimulates or not the desire and intention formation of becoming an entrepreneur. Two Universities were selected for collecting samples: the first one, "Luiz de Queiroz" College of Agriculture (ESALQ), and the second herein called PRI (ficticious name). After that, the survey has contemplated a number of 493 valid questionnaires applied to both groups of both schools. The survey was elaborated by assuming that desire and intention are dependent variables and that the former stimulates the latter, besides considering that they are key variables to understand the formation of entrepreneurs' figures. It was defined that the students belong to three excluding occupational groups: private initiative employee, civil servant and entrepreneur. Differences between two groups' answer frequency were supposed to be caused by the educational process. Qui-square test has confirmed that the differences found between freshmans' and seniors' answers are statistical significant, which allows to imply that there is an effect of the institutions on the desire and intention formation of becoming an entrepreneur and other considered professions. Non-parametric tests were used aiming to know the determination of occupational choice. Yet, factorial analysis has outlined which factors largely affect the formation of freshmans' and seniors' desire in terms of professional occupation. The results show that higher education institutions stimulate the desire and intention formation of becoming entrepreneurs. The comparison of two groups in ESALQ indicates that there is an increase of the students' group with desire and intention of becoming entrepreneurs. Nevertheless, the outcomes highlight that a fraction of senior students would like to be entrepreneurs, although they are not sure about their chances of effectively becoming ones. This might be verified because ESALQ training possibly drives the students towards to private sector. This hypothesis is confirmed by the difference of the percentage of ESALQ senior student that desires and intends to become employees of whatever private company, whereas PRI senior students behaves differently, given that the intentions of becoming an entrepreneur outnumbers the desiring of owning entrepreneurial activities.

Keywords: Entrepreneurial desire; Entrepreneurial intentions; Occupational choice; Education and Occupational choice; Undergraduate course and entrepreneur 


\section{LISTA DE FIGURAS}

Figura 1 - Brasil: percentual, por nível de escolaridade, do total de desempregados. 21

Figura 2- Esquematização da estrutura do trabalho.

Figura 3 - Linha do tempo dos economistas que analisaram o empresário em seus trabalhos.......26

Figura 4 - Intenção e variáveis que a formam e derivam...........................................................52

Figura 5 - Teoria do comportamento planejado de Ajzen ...........................................................53

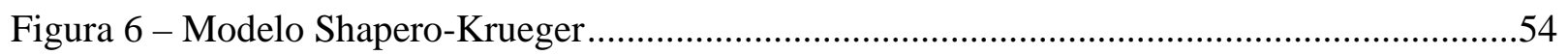

Figura 7 - Modelo dos fatores pessoais, contextuais e experimentais que afetam o comportamento de escolha por uma carreira ............................................................................59

Figura 8 - Esquematização da proposta de Bagozzi (2000).......................................................61

Figura 9 - Modelo explicativo do comportamento empresarial dos indivíduos ............................65

Figura 10 - Esquematização dos fatores que explicam a escolha por uma ocupação profissional.66

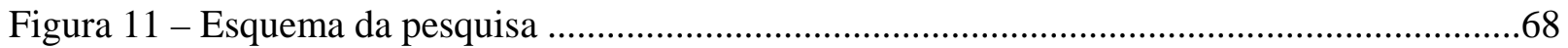

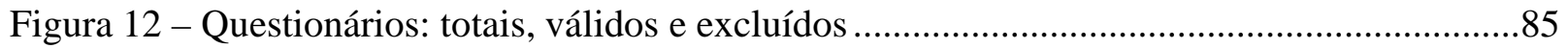

Figura 13 - Cursos: participação dos cursos avaliados dentre os questionários aplicados .............87

Figura 14 - Percentual, por instituição, do perfil ocupacional dos estudantes amostrados ............91

Figura 15 - Percentual do tipo ocupacional dos ingressantes, por curso .....................................95

Figura 16 - Percentual do tipo ocupacional dos alunos formandos, por curso...............................96

Figura 17 - Porcentagem de estudantes ingressantes por opção ocupacional que acredita que ocupará a opção que gostaria de desempenhar

Figura 18 - Porcentagem de formandos por opção ocupacional que acreditam que ocuparão a opção que gostariam de desempenhar 100

Figura 19 - Porcentagem de alunos ingressantes por opção ocupacional e curso considerando-se o gênero 102

Figura 20 - Número de formandos por religião e freqüência ao templo religioso........................104

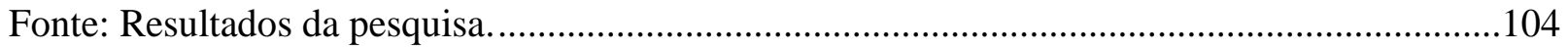

Figura 21 - Porcentagem dos questionários válidos por opção ocupacional e religião considerando-se a freqüência de visita ao templo da religião ....................................................105

Figura 22 - Histograma com curva de ajustamento normal da variável idade............................106

Figura 23 - Boxplots para avaliação da presença de outliers e valores extremos .........................107

Figura 24 - Histograma com curva de ajustamento normal da variável renda ............................108 
Figura 25 - Gosto por preferência ocupacional, por faixa de renda familiar mensal, considerandose o curso

Figura 26 - Disposição a pagar dos alunos ingressantes por um bilhete de loteria, dado o gosto por uma preferência ocupacional, considerando-se a renda familiar mensal

Figura 27 - Valores pagos pelos formandos por um bilhete de loteria dada a renda familiar mensal113 Figura 28- Porcentagem de alunos formandos por opção ocupacional desejada e curso considerando-se o gênero 126

Figura 29- Número de formandos por religião e freqüência ao templo religioso. 129

Figura 30- Porcentagem dos questionários válidos por opção ocupacional e religião considerando-se a freqüência de visita ao templo da religião 130

Figura 31 - Histograma com curva de ajustamento normal da variável idade. 132

Figura 32 - Boxplots para avaliação da presença de outliers e valores extremos 133

Figura 33 - Histograma com curva de ajustamento normal da variável renda 134 Figura 34 - Gosto por preferência ocupacional, por faixa de renda familiar mensal, considerandose o curso .135

Figura 35 - Disposição a pagar dos alunos formandos por um bilhete de loteria, dado o gosto por uma preferência ocupacional, considerando-se a renda familiar mensal 138 Figura 36 - Valores pagos pelos formandos por um bilhete de loteria dada a renda familiar mensal139 


\section{LISTA DE TABELAS}

Tabela 1 - Listagem das questões a ser pesquisadas . .72

Tabela 2 - População e participação na população dos alunos ingressantes e formandos pelas instituições PUB - ESALQ e PRI por curso avaliado . .84

Tabela 3 - Definição do tipo ocupacional dada à primeira opção assinalada .88

Tabela 4 - Percentual da escolha dos estudantes pelos perfis considerados .89

Tabela 5 - Estatística descritiva para a variável idade..... 106

Tabela 6 - Estatística descritiva da disposição a pagar por um bilhete de loteria.....

Tabela 7 - Teste de Normalidade de Kolmogorov - Smirnov para os fatores que impedem com que as preferências ocupacionais dos ingressantes não correspondam às posições que gostariam de ocupar

Tabela 8 - Matriz de resultados do teste de Wilcoxon para a diferença entre os fatores que impedem que a crença não corresponda à preferência ocupacional dos ingressantes 115 Tabela 9 - Teste de Kruskal - Wallis para identificar a influência dos fatores que impedem com que crenças coincidam com a opção que gostaria por perfil ocupacional. .116 Tabela 10 - Teste de Normalidade de Kolmogorov - Smirnov para os fatores que influenciam nas preferências ocupacionais dos ingressantes.

Tabela 11 - Matriz de resultados do teste de Wilcoxon para a diferença entre os fatores que influenciam na decisão de escolha ocupacional

Tabela 12 - Teste de Kruskal - Wallis para identificar a influência dos fatores na decisão de escolha ocupacional.

Tabela 13 - Teste de Normalidade de Kolmogorov - Smirnov para testar distribuição do grau de influência das pessoas do círculo dos ingressantes na decisão de escolha ocupacional. 120 Tabela 14 - Matriz de resultados do teste de Wilcoxon entre o grau de influência das pessoas do círculo dos ingressantes na decisão de escolha ocupacional .

Tabela 15 - Teste de Kruskal - Wallis para identificar a influência dos fatores que influenciam na decisão de escolha ocupacional 122

Tabela 16 - Teste de Normalidade de Kolmogorov - Smirnov para fatores que os ingressantes consideram importantes no curso universitário para auxiliá-los em seu desempenho profissional123 
Tabela 17 - Matriz de resultados do teste de Wilcoxon para fatores que os ingressantes consideram que importantes no curso universitário para auxiliá-los no desempenho profissional124 Tabela 18 - Teste de Kruskal - Wallis para fatores que os ingressantes consideram importantes no curso universitário para auxiliá-los no desempenho profissional.................................................125 Tabela 19 - Estatística descritiva para a variável idade ..........................................................131 Tabela 20 - Estatística descritiva da disposição a pagar por um bilhete de loteria.......................137 Tabela 21 - Teste de Normalidade de Kolmogorov - Smirnov para os fatores que impedem com que as preferências ocupacionais dos formandos não correspondam às posições que gostariam de ocupar

Tabela 22 - Matriz de resultados do teste de Wilcoxon para a diferença entre os fatores que impedem que a crença não corresponda à preferência ocupacional dos formandos 142 Tabela 23 - Teste de Kruskal - Wallis para identificar a influência dos fatores que impedem com que crenças coincidam com a opção que fariam por perfil ocupacional.

Tabela 24 - Teste de Normalidade de Kolmogorov - Smirnov para os fatores que influenciam nas preferências ocupacionais dos formandos 144 Tabela 25 - Matriz de resultados do teste de Wilcoxon para a diferença entre os fatores que influenciam na decisão de escolha ocupacional 145 Tabela 26 - Teste de Kruskal - Wallis para identificar a influência dos fatores na decisão de escolha ocupacional 146 Tabela 27 - Teste de Normalidade de Kolmogorov - Smirnov para testar distribuição do grau de influência das pessoas do círculo dos formandos na decisão de escolha ocupacional 147 Tabela 28 - Matriz de resultados do teste de Wilcoxon entre o grau de influência das pessoas do círculo dos formandos na decisão de escolha ocupacional 148 Tabela 29 - Teste de Kruskal - Wallis para identificar a influência dos fatores que influenciam na decisão de escolha ocupacional Tabela 30 - Teste de Normalidade de Kolmogorov - Smirnov para fatores que os formandos consideram que importantes no curso universitário para auxiliá-los no desempenho profissional150 Tabela 31 - Matriz de resultados do teste de Wilcoxon para fatores que os formandos consideram importantes no curso universitário para auxiliá-los no desempenho profissional. .151 Tabela 32 - Teste de Kruskal - Wallis para fatores que os formandos consideram importantes no curso universitário para auxiliá-los no desempenho profissional. .152 
Tabela 33 - Variância explicada pelos fatores na solução inicial e na solução rotacionada 154

Tabela 34 - Determinação das variáveis componentes em cada fator, após a rotação pelo método Varimax 155

Tabela 35 - Variância explicada pelos fatores na solução inicial e na solução rotacionada 158 Tabela 36 - Determinação das variáveis componentes em cada fator, após a rotação pelo método Varimax

Tabela 37 - Freqüência dos valores assinalados pelos estudantes ingressantes dos fatores que limitam que o gosto se torne intenção 162 Tabela 38 - Freqüência dos valores assinalados pelos estudantes formandos dos fatores que limitam que o gosto se torne intenção .163

Tabela 39 - Freqüência dos valores assinalados pelos estudantes ingressantes de perfil empresarial dos fatores que esperam que facilitem com que o gosto se torne intenção. 164 Tabela 40 - Freqüência dos valores assinalados pelos estudantes formandos com perfil empresarial dos fatores que poderiam tê-los auxiliado no desempenho de atividade empresarial165 


\section{INTRODUÇÃO}

\subsection{Definição do problema}

Neste trabalho buscar-se-á responder à seguinte questão: Quais são os determinantes na preferência e na intenção de se tornar empresário dentre estudantes que iniciaram e estão terminando seu curso superior? A motivação para a realização deste estudo é o fato de este tópico não ter tido a ênfase necessária na literatura, apesar da sua incontestável importância. Ainda, a análise no contexto universitário visa ao conhecimento da relação tipo de educação e formação do estoque de empresários. Supõe-se a existência de um tipo de educação que forme predominantemente funcionários, e é possível ter um modelo de educação que auxilie na formação de empresários. Desta forma, a identificação de tal relacionamento pode auxiliar na busca de um modelo de educação que vise também à formação de empresários.

Ao avaliar os estudos com relação ao empreendedorismo pode-se considerar que há dois níveis de análise. O primeiro relaciona-se com a decisão e a atuação dos indivíduos, sendo que estes podem optar por desenvolver a atividade empresarial individual ou dentro de um grupo. O outro nível trata da análise com foco em firma e indústria, assim como organizações governamentais e não-governamentais; bem como em questões ligadas a espaços, por exemplo: cidades, regiões e países. Sumarizando, os estudos se enquadram ou em nível individual, no qual está inserido este estudo, ou então, no âmbito da firma.

Na literatura há grande discussão acerca de conceitos como capital empresarial, empreendedorismo e empresários. Assim, é oportuno desde já explicitar os conceitos que serão utilizados neste trabalho. O conceito de capital empresarial é uma proposta teórica recente e como tal, vem sendo aperfeiçoada. Na literatura reportada, o primeiro trabalho encontrado sobre o conceito é de 2004 (a), de autoria de Audresch e Keilbach. A partir desse trabalho, aperfeiçoamentos acerca da terminologia vêm sendo realizados, sendo que um dos mais recentes conceitua o capital empresarial como um fator de produção independente, seguindo a proposta de Jean Baptiste Say (AUDRETSCH, HEBLICH e MONSEN, 2007). Ainda na linha de aperfeiçoamento da proposta, Audresch e Monsen (2007) defendem a abordagem em quatro níveis: o individual, a equipe, a organização e a região. No presente estudo, os termos 
empreendedorismo e empresário seguem a proposta utilizada no trabalho de Lazear (2005). Para o autor, empreendedorismo é o processo de reunir fatores de produção necessários de uma forma eficiente. Empresário é o agente que coloca pessoas juntas de uma maneira particular e combinaas com capital físico e idéias para criar novos produtos ou serviços; ou então, produzir algum existente a um custo competitivo.

Um aspecto que deve ser salientado trata de inovação versus imitação. Conforme salientado por Lazear (2005), ao se imaginar empresários de sucesso faz-se a ligação com proposição de novas idéias. No entanto, o autor faz a ressalva que em uma visão generalista de empreendedorismo reduz-se a ênfase em inovação, apesar de inovação não ser inconsistente com o conceito. Neste trabalho, o enfoque se deu na identificação dos determinantes que explicam o gosto e a intenção de estudantes em tornar-se empresários ou funcionários. Assim, dada a sua visão generalista, a questão de inovação não foi incorporada. Entendeu-se que a característica inovativo não pode ser considerada como um ponto de conceituação para ser empresário ou não. Existem empresários que são inovativos, mas também existem funcionários que são inovativos, ou seja, inovação não é um ponto crucial para se definir empresário. Em consonância com este ponto, ao inquirir os estudantes quanto ao seu gosto e a sua intenção de ser empresário ou empregado, não foi avaliado se o estudante era inovativo ou não. Buscou-se identificar se o estudante tinha desejo e/ou intenção de ser empresário, independentemente de sua possível atuação ser inovativa, ou se iria imitar algo já existente.

Sintetizando, no presente estudo visa-se identificar quais fatores influenciam e afetam a pretensão de ser empresário entre estudantes universitários ingressantes e estudantes formandos. O conhecimento de tais determinantes pode auxiliar na identificação de como estimular a formação de estoque de capital empresarial dentre esta população estudada. O capital empresarial, em todos os níveis de análise, é de suma importância para o desenvolvimento econômico, entretanto, seus determinantes são pouco conhecidos. Este tema começou nas últimas décadas a ganhar espaço nas discussões acadêmicas e é relevante nas discussões científicas, sobretudo as de cunho econômico. 


\subsection{Objetivos}

O presente estudo procura investigar a existência de um conjunto de características que expliquem o gosto e/ou a intenção de ser empresário versus funcionário entre estudantes que iniciam e terminam seu curso em nível superior.

- $\quad$ Descrever fatores que explicam a opção por ser empresário;

- Identificar se ao longo do curso superior há mudança no gosto e na intenção dos estudantes em, possivelmente, se tornarem empresários; e

- Determinar quais fatores têm maior influência na intensão dos estudantes em não ser empresário.

\subsection{Justificativa}

O estudo do capital empresarial em qualquer setor da economia é relevante por este ser um dos fatores que explicam o crescimento e o desenvolvimento econômico. A visão de que o crescimento econômico advém somente do aumento dos capitais físico, financeiro e natural não é mais válida. Os capitais social, humano e empresarial também são estoques que explicam os diferentes graus de crescimento econômico em certas regiões. No entanto, apesar da clara influência do capital empresarial no processo de crescimento, somente alguns pensadores trataram do assunto no campo das ciências econômicas. Observa-se que nas demais ciências sociais, em geral, a pesquisa sobre tal recurso não tem ainda grande ênfase, apesar da sua incontestável importância. Djankov et al. (2004) afirmam que na área de administração encontrase uma vasta literatura, principalmente aplicada a países desenvolvidos; entretanto, verifica-se que esses estudos apresentam limitação quanto à teoria e ao rigor de análise empírica.

O problema da escassez de pesquisas com relação ao desenvolvimento de uma teoria sobre capital empresarial tem diversas implicações. Do ponto de vista macroeconômico, a consideração de análises deste tipo de capital possivelmente permitirá melhor entendimento do processo de crescimento. Além desta hipótese acerca da sua relevância sob uma ótica de compreensão de crescimento econômico, o capital empresarial em um ambiente globalizado tem relevo também. É incontestável a mudança na estrutura de empregos dos países em que a busca por redução de 
custos conduz ao aumento no número dos processos de parcerias. Tais parcerias implicam na necessidade dos indivíduos atuarem como empresários; assim, há uma substituição da demanda por empregados pela demanda por empresários. Desta forma, dada a importância do capital empresarial é necessário identificar e conhecer o comportamento dos seus determinantes.

O potencial do poder explicativo do capital empresarial na teoria do crescimento econômico deve ser investigado. Em um breve resumo da discussão acerca do processo de crescimento econômico verifica-se que tal estudo data do início do tratamento da economia como ciência. No entanto, na literatura, é considerado que o estabelecimento da teoria do crescimento como uma área de estudo independente teve início com os trabalhos de Harrod e de Domar, no final da primeira metade do século XX (BRESSER-PEREIRA, 1975; SOLOW, 1994; DUARTE, 2003). Contudo, a apresentação de modelos matemáticos remonta à proposta de Solow (1956), e a partir daí, em ondas, vêm sendo verificadas tentativas de aperfeiçoamento da teoria de crescimento econômico.

O modelo proposto por Solow (1956), denominado modelo de crescimento exógeno, explica o crescimento como resultado da acumulação de capital e mudanças tecnológicas autônomas. O modelo está fundamentado em uma função de produção dependente do estoque de capital e trabalho. O conceito de capital adotado pelo autor é o neoclássico, ou seja, bens compostos acumulados pela população. Tal conceito de capital é passível de contestação, sendo que a denominada Controvérsia do Capital é uma representação da discussão sobre a utilização desta conceitualização de capital. Robinson (1953) questiona vários pontos do conceito, como por exemplo, a unidade em que é mensurado, uma vez que a acumulação conduz à idéia de quantidade física.

Uma segunda geração de modelo, denominado endógeno, surgiu com os trabalhos de Romer (1986) e Lucas (1988). Os autores constataram empiricamente que o poder explicativo do modelo proposto por Solow (1956), quando aplicado às diversas economias, não pode ser considerado bom. Desta forma, eles sugerem que seja discutida a interpretação sobre o papel da tecnologia, uma vez que para Solow (1956) é uma variável exogenamente determinada. Os modelos propostos pela vertente endógena assumem que o conhecimento é um fator de produção, assim, incorporam o capital humano como proxy para este fator de produção nas funções de produção. O capital humano representa o estoque de conhecimento produtivo e criativo dos indivíduos (EHRLICH, 2007). 
A busca por aperfeiçoamento dos modelos de crescimento econômico, vem mais recentemente, incorporando às análises um tipo de capital adicional. Este capital é denominado social, sendo oportuno salientar que a sua definição é fruto de grande discussão na literatura. Visando apresentar um conceito deste tipo de capital, far-se-á referência a um conceito citado por García et al. (2006), cuja proposição é do Grupo de estudo em capital social da Universidade de Michigan. Tal conceito proposto pelo grupo considera capital social como o resultado de relacionamentos sociais, sendo composto pelas expectativas de benefício derivados do tratamento preferencial entre indivíduos ou grupos. García et al. (2006) enfatizam que em consonância com este conceito, as relações sociais são um ativo; assim, a discussão da dimensão econômica com respeito a este tipo de capital é pertinente. Os autores ainda salientam que há carência de estudos que abordem o capital social como um recurso que é acumulado, dada a decisão de investimento de agentes racionais.

Sintetizando, atualmente existe uma controvérsia na teoria do crescimento econômico, pois há autores que entendem a variável tecnologia como endógena, e outros que entendem esta variável como exógena. A dúvida acerca da inclusão do capital humano nos modelos de crescimento foi solucionada com o trabalho de Mankiw, Romer e Weil (1992). Os autores, ao incorporarem o capital humano em um modelo exógeno, obtiveram como resultado o aumento do seu poder explicativo. A incorporação, bem como a forma de incluir o capital social nas funções de produção, é outro ponto discutido. Desta forma, fica evidenciado que na recente teoria do crescimento econômico há muito a ser identificado e discutido, a fim de que os modelos melhor se ajustem aos fatos estilizados. Dentro desta proposta de aperfeiçoamento, são plausíveis as considerações sobre o papel do capital empresarial, em função do poder explicativo dos diferentes níveis de crescimento. No entanto, é necessário que os determinantes do capital empresarial sejam identificados.

No presente estudo sugere-se que seja aprofundada a investigação acerca do papel do capital empresarial como um dos tipos de capitais que explicam o processo de crescimento. Considerando tal sugestão, este estudo contribui para a discussão ao pretender identificar e conhecer determinantes do capital empresarial. Um dos níveis deste tipo de capital é o individual; assim, discussões que visem conhecer o processo de formação do gosto e da intenção do indivíduo de se tornar empresário são relevantes. Desta forma, tal conhecimento possibilita o planejamento e a implementação de medidas que visem estimular a formação deste tipo de 
estoque. Entretanto, na literatura reportada não são encontrados muitos estudos desta natureza aplicados ao Brasil. As origens e os fatores que afetam o recurso empresarial brasileiro são pouco conhecidos. Essa carência de estudos resulta em prejuízo para o planejamento e para a implementação de políticas que visem estimular o crescimento e o desenvolvimento através de estratégias empresariais.

Os empresários, no contexto de mudanças que a economia vem passando, são cada vez mais importantes para um bom desempenho da economia. Um exemplo de atividade econômica que cada dia mais necessita de empresários é a agricultura. Considerando-se a importância da agricultura para a economia brasileira enfatiza-se que o conhecimento dos determinantes do estoque de capital empresarial é mais relevante. As diversas crises e transformações pelas quais vem passando essa atividade reflete a necessidade de mudança de postura dos produtores agrícolas. Somente a postura de especialista não garante a sobrevivência deles. Bergevoet (2005) salienta que até recentemente um fazendeiro poderia atingir posição de sucesso se tivesse habilidade e experiência nas atividades da propriedade, além de capacidade de implementação e de controle das atividades. Atualmente, entretanto, além desses papéis é necessário que os proprietários rurais também tenham a competência para tomar decisões estratégicas. Tal competência é uma condição para a sobrevivência do produtor rural, principalmente por este ser o elo da cadeia produtiva que opera em uma estrutura de mercado mais próxima da denominada “competição perfeita”.

O movimento mundial de globalização é um fator que acentua a relevância da discussão acerca do capital empresarial. O crescente processo de globalização implicou em acentuamento das transformações na maneira de realizar os negócios e na estrutura interna das empresas. Uma dessas transformações foi o aumento do processo de terceirização, com o objetivo de transferência de riscos, mas que também visa ganhos de qualidade e eficiência. Entretanto, conforme assinalado por Peres e Canziani (2005), trata-se de uma forma de organização e gestão do trabalho utilizada na agropecuária há muito tempo. A tradicional parceria presente na agropecuária é a terceirização, que passou a ser utilizada nos setores industriais e de serviços, notando-se, assim, uma diferença de nomenclatura. O setor primário, por operar em uma estrutura de mercado que tende à competição perfeita, sempre buscou formas de gestão que permitissem ganhos de eficiência. Contudo, não discutindo denominações utilizadas pelas atividades econômicas, um dos efeitos da parceria é a redução do número de postos de trabalho assalariado. 
Em contrapartida, há aumento da demanda por recurso empresarial, o que conduz à necessidade de indivíduos com as qualificações específicas para serem empresários.

A mudança da estrutura de emprego, isto é, menor demanda por empregados, ainda não tem grande impacto para os portadores de diploma de nível superior. Uma pesquisa realizada pela Organização para a Cooperação e Desenvolvimento Econômico - OCDE, revelou que a probabilidade de desemprego para os portadores de diploma superior se mantém constante (DEUTSCHE WELLE, 2007). Um aspecto relevante apontado nesse estudo diz respeito ao impacto do desemprego para os menos qualificados, dado o aumento do nível educacional da população. Citam-se como exemplo países como a França, a Irlanda e a Coréia do Sul, que no período de 1995 a 2004 apresentaram aumento significativo do nível educacional, houve ou a redução ou a constância do nível de desemprego dentre os menos qualificados. Enquanto em países como a Alemanha, a República Tcheca e a Eslováquia houve pequena elevação do nível educacional, verifica-se que o nível de desemprego aumentou para os menos qualificados. Conclui-se que a elevação do nível de educação tem impacto no nível de desemprego dos menos qualificados, entretanto, o mecanismo que explica tal resultado não foi explicado no texto consultado. No caso do Brasil, conforme Figura 1, observa-se que no período avaliado houve aumento, em pequena magnitude, do desemprego dentre aqueles que têm diploma em nível superior. No entanto, o nível de desemprego, assim como nos países avaliados pelo estudo da OECD, é pequeno quando comparado com os menos qualificados. 


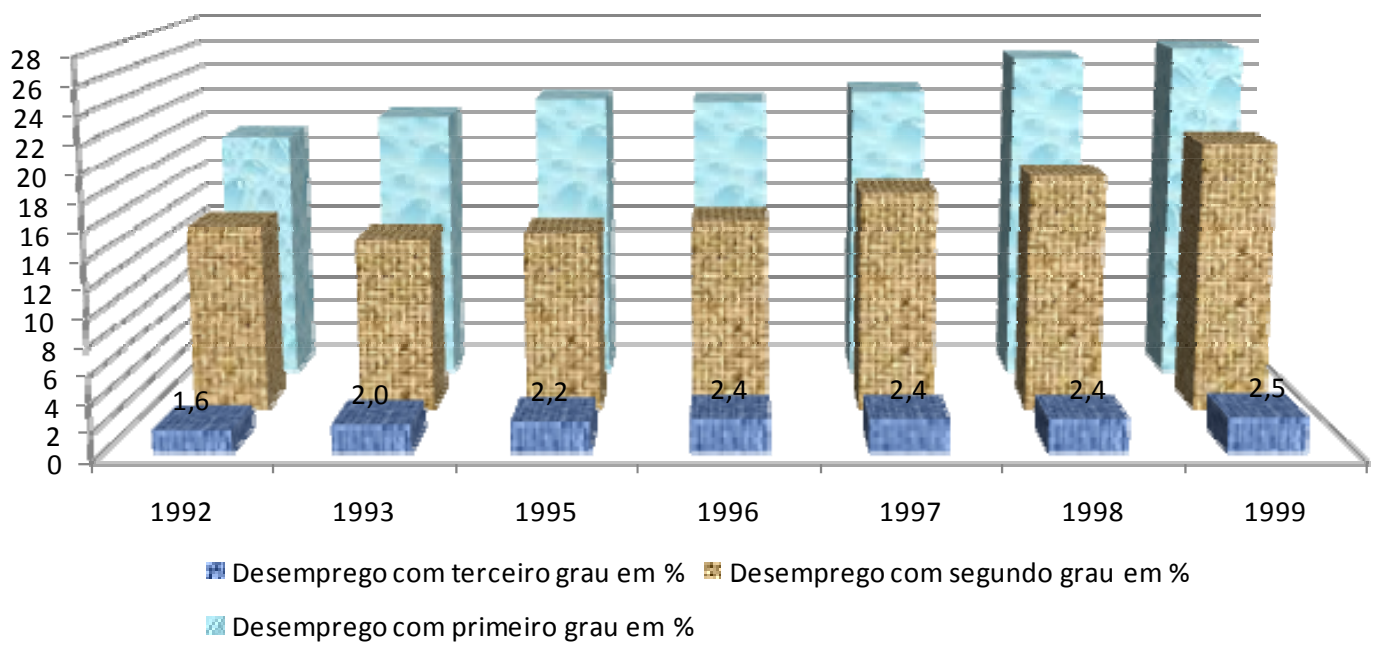

Figura 1 - Brasil: percentual, por nível de escolaridade, do total de desempregados Fonte: World development indicators (2005)

O menor nível de desemprego dentre os portadores de diploma de nível superior não implica em não se preocupar em buscar entender e, conseqüentemente, estimular que estes estejam aptos a identificar novas oportunidades. Como já salientado, é importante para o crescimento da economia a presença de empresários. Phelps (2006) enfatizou que a economia brasileira pode acelerar seu crescimento, entretanto, os empecilhos para isso eram as instituições e a cultura econômica que inibem inovações. O economista chama a atenção para o capitalismo dinâmico, em que o empresário é incentivado a investir e inovar sem encontrar obstáculos com relação a questões burocráticas, institucionais e corporativas. Phelps (2006) fez a ressalva que não defende um Estado zero, ausência de impostos, mas que o setor privado tem que contar com condições para ser dinâmico. Desta forma, mesmo que o índice de desemprego para os portadores de diploma superior seja menor comparativamente aos menos qualificados, é relevante que se identifique a formação do gosto, da intenção, do comportamento e os resultados para se tornarem empresários.

Em síntese, para se buscar entender os determinantes da opção ocupacional empresário em detrimento de empregado existem principalmente duas justificativas. Uma é que as diversas mudanças que vêm ocorrendo no mundo têm como uma das conseqüências a realocação dos fatores de produção nos processos produtivos. Outra, é a importância da utilização de estratégias para formar um capital empresarial competente para se atingir maiores índices de crescimento. 
Com relação à primeira razão, tem-se que a tendência é que sejam usados menos intensivamente os fatores recursos naturais e trabalho, substituindo-os pelos outros fatores de produção. Tal processo tem como resultado a modernização da organização de produção e das relações trabalhistas, visando ao aumento da produtividade e da rentabilidade, uma vez que a forma de alocação dos fatores de produção tem influencia direta nos preços dos fatores e nos custos de produção. Desta forma, o recurso empresarial ganha relevo, já que é responsável pela organização dos demais fatores de produção, e os resultados positivos ou negativos de sua atuação dependem da sua eficácia. Já na questão de crescimento, tem-se que a elaboração e a implementação de estratégias de desenvolvimento, as quais objetivem formar um capital empresarial capaz de identificar oportunidades, são alternativas que cada vez mais serão necessárias para minimizar as desigualdades. A relevância de optar por esta estratégia é evidenciada pelas colocações de Petrin (2005) e Hazell \& Haddad (2001). Petrin (2005) assinala que a não existência de bons empresários compromete o sucesso de políticas de desenvolvimento fundamentadas em outros aspectos, como crédito. A autora cita que evidências sugerem que a injeção de capitais externos em regiões social e economicamente deprimidas não resulta em áreas desenvolvidas. Já Hazell e Haddad (2001) fazem referência à mudança do papel da pesquisa pública agrícola, mas que pode ser extrapolada para diversas áreas. Os autores enfatizam que as questões relacionadas com a produtividade estão sendo realizadas pelo setor privado. Desta forma, o setor público pode contribuir para o crescimento e desenvolvimento rural por intermédio da implementação de políticas que visem à qualidade do capital empresarial agrícola.

\subsection{Estrutura do estudo}

O trabalho é apresentado em cinco partes descritas na Figura 2: 


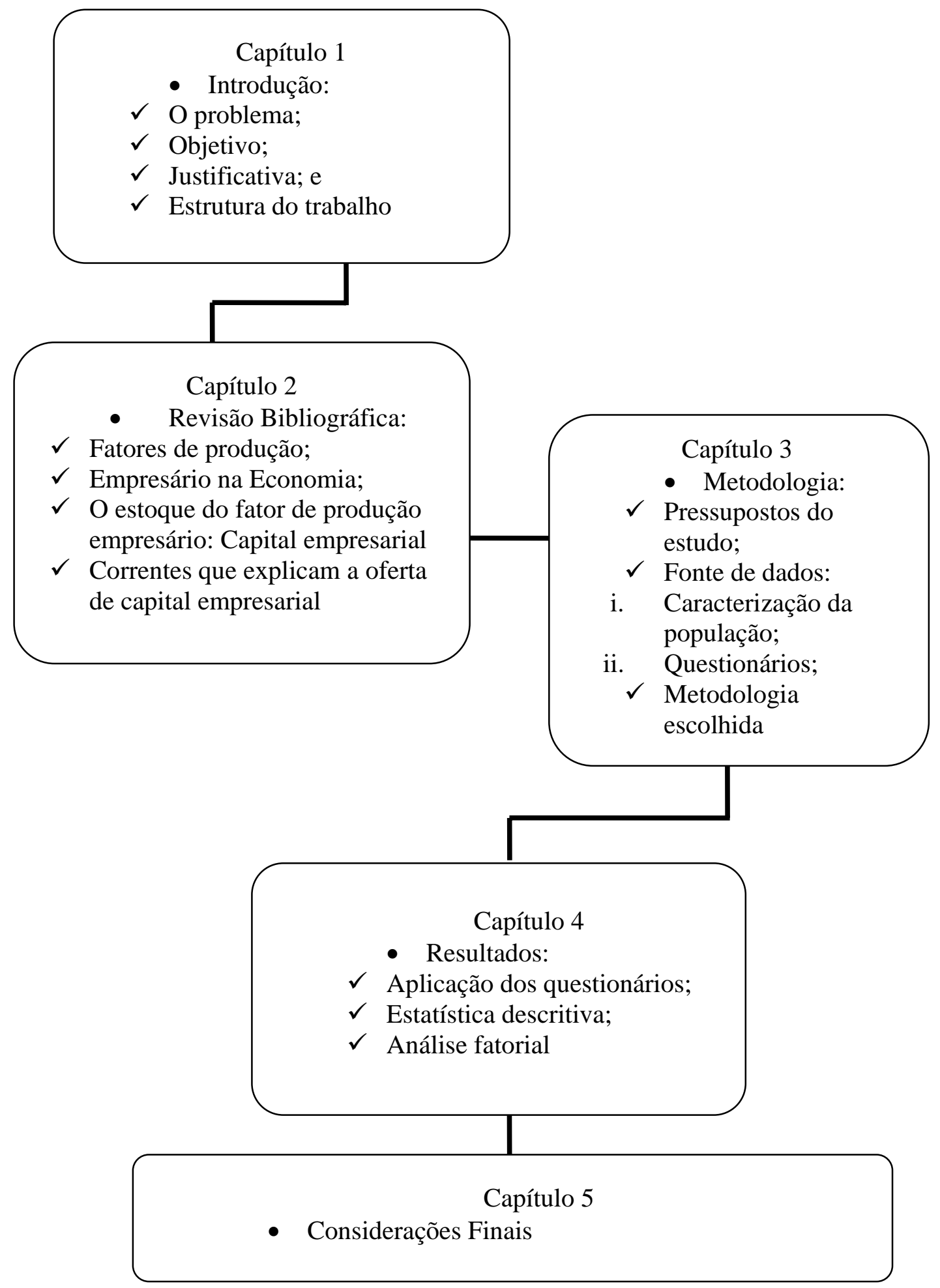

Figura 2- Esquematização da estrutura do trabalho

Fonte: Elaborado pela autora 


\section{REVISÃO BIBLIOGRÁFICA}

\subsection{Fatores de produção}

A discussão acerca da classificação do que constitui fator de produção na economia não é unanimidade na teoria econômica. Em geral, foram poucos os economistas que consideraram aspectos humanos ligados à empresa, além dos trabalhadores, como fator de produção. Isto acarreta em que o empresário e o capital empreendedor, dentro das discussões econômicas, sejam relegados muitas vezes a um segundo plano nas ciências econômicas. Jean Baptiste Say (1890) foi um dos primeiros economistas que propôs que se considere, ao invés de trabalhadores, o fator de produção indústria humana (AUDRETSCH, HEBLICH e MONSEN, 2007). A defesa de Say era que este fator incluía três componentes importantes, resultantes da existência da divisão do trabalho. Estes componentes são os pesquisadores, os empresários e os trabalhadores. Aos primeiros cabia o desenvolvimento de invenções; enquanto os empresários seriam responsáveis por comercializar as invenções; assim, estas passam a ser inovações. O terceiro componente do fator de produção indústria humana eram os trabalhadores, que produziam os produtos. A proposta da Say pode ser associada à defesa da existência de um capital empreendedor, uma vez que o empresário é tanto relacionado ao capital empreendedor quanto ao fator de produção indústria humana.

Em geral, os economistas clássicos, com exceção de Say, descreviam como requisitos de produção os fatores terra, mão-de-obra e capital. Assim, nota-se que os empresários estavam ausentes das análises econômicas, apesar de ser necessário a existência de um agente responsável por organizar estes fatores para produção de bens e serviços e, acima de tudo, incorrer nos riscos necessários. John Stuart Mill considerava que as formas de remuneração a cada detentor desses requisitos eram aluguéis ou rendas, salários e lucros, respectivamente. O lucro era composto dos seguintes componentes: juros, seguros e salários de superintendentes ou gerentes (WARBURTON, 1928). Entretanto, tal classificação era adequada à economia do século XIX, conforme enfatizado por Warburton (1928). Mesmo com a ressalva feita por Warburton quanto à adequação da proposta ao seu tempo, observa-se que a questão referente aos componentes do lucro é passível de ser contestada. Considerar os componentes defendidos por Mill como elementos do lucro revela uma confusão entre a remuneração do que seria capital e de um fator 
de produção, não considerado, em geral, pelos clássicos. É preciso considerar a existência de uma agente responsável pela organização dos demais fatores de produção a fim de ser ter produtos.

A partir do século XX nota-se que as principais obras de economia passaram a não mais seguir tais terminologias econômicas dos clássicos. Warburton (1928) fez uma análise das principais obras do final do século XIX e início do século XX, encontrando uma variedade de abordagens. Por exemplo, Marshall, em sua obra "Princípios de Economia”, 1890, além de substituir o termo requisito de produção por fatores ou agentes de produção, afirma que “... por vezes é melhor admitir organização como um agente de produção a parte e distinto”. Pigou argumentava que tomadores de incerteza deveriam ser considerados um fator de produção. Broucke e Bye consideravam empresa como um fator de produção e, para Turner, o empresário seria um quarto fator de produção (WARBURTON, 1928). Desta forma, verifica-se a partir daí preocupação de alguns economistas quanto à necessidade de se incorporar como um agente de produção a atividade empresarial.

Sumarizando, a existência de uma forma de remuneração denominada lucro é reconhecida pela teoria econômica. No entanto, ainda não há unanimidade da existência de um fator de produção associado à organização dos demais fatores de produção e que incorre em riscos oriundos do processo empresarial. Reconhecendo-se que há um fator de produção responsável pela organização dos demais fatores, o lucro seria a forma de remuneração a este fator.

\subsection{Empresário na economia}

O empresário ou a indústria humana, ou qualquer outra denominação que busque associar a atividade de coordenação dos demais fatores de produção, em geral, não é considerado um fator de produção independente. Esta limitação persiste ao se verificar que o empresário não é incorporado de nenhuma forma à maioria dos modelos econômicos formais. Baumol (1968) chama a atenção para esta questão satirizando que "a firma teórica não tem empresário - o príncipe da Dinamarca foi omitido das discussões de Hamlet” (BAUMOL, 1968, p. 66). Se na década de 60 do século passado Baumol já assinalava esta limitação, Audretsch, Heblisch e Monsen (2007) citam o referido autor e assinalam que recentemente o problema persevera.

Ao longo da história do pensamento econômico, não se pode afirmar que o empresário esteve completamente fora das discussões econômicas. Alguns economistas abordaram o 
conceito econômico de empresário, entretanto, é consenso de que o papel do recurso empresarial na teoria econômica não foi destacado devidamente (PAULA et al.., 2000; CORRÊA; BÊRNI, 2000; IBRAHIM; VYAKARNAM, 2003). Na Figura 3 apresenta-se uma linha do tempo com alguns dos pensadores que discutiram o conceito empresário em suas obras e são referenciados neste item.

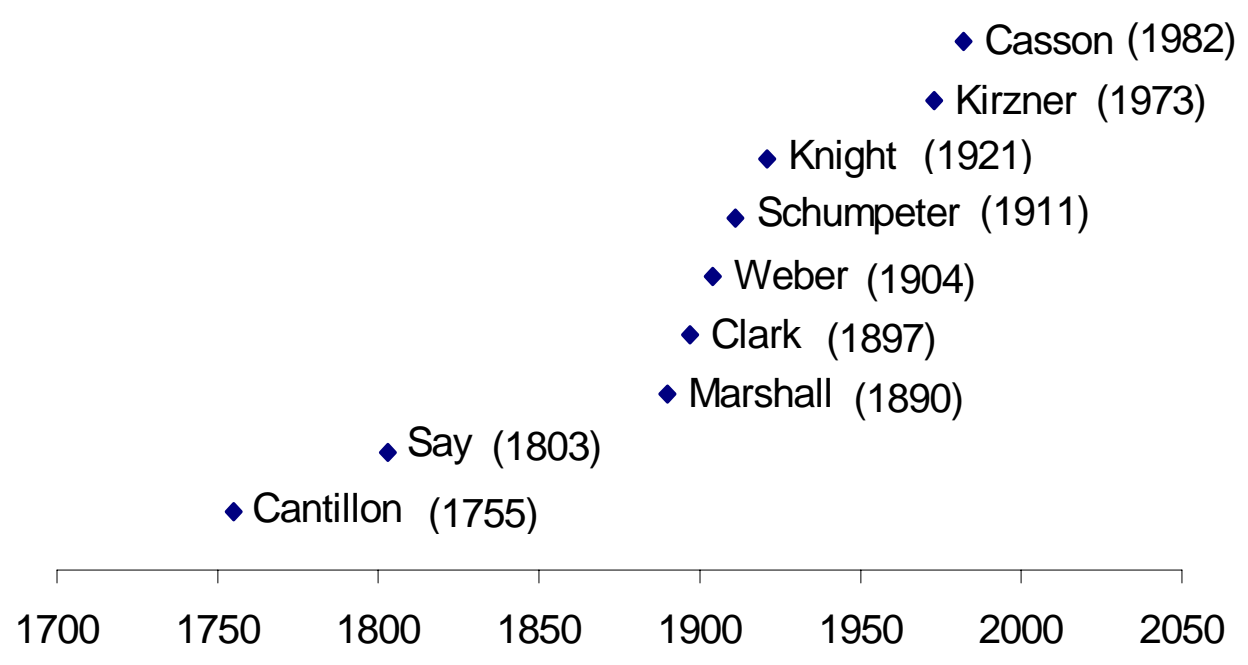

Figura 3 - Linha do tempo dos economistas que analisaram o empresário em seus trabalhos Fonte: Elaborado pela autora.

O primeiro economista a referir-se à questão foi Cantillon, em seu Ensaio sobre a Natureza do Comércio em Geral, publicado em 1755 (VAN PRAAG, 1999; PAULA et al.., 2000). O autor tem o empresário como um arbitrador que assume riscos com função de equilibrar o sistema econômico. A incerteza tem o papel de garantir a existência deste agente.

De acordo com Paula et al.. (2000), depois de Cantillon foi Say quem reconheceu a função econômica dos empresários. Para Say, os empresários eram agentes que organizavam e utilizavam os demais insumos, viabilizando a produção de bens e serviços. A partir da receita da venda de seus produtos, os empresários remuneravam os demais fatores de produção, tais como juros ao capital, rendas aos recursos naturais e salários à mão-de-obra. Após o pagamento desses fatores, a diferença remunerava a sua atividade. 
A abordagem do conceito de empresário pela escola clássica não recebeu significativo destaque. Knight (1971) explica que na escola clássica inglesa considerava-se como única a figura do empresário e do proprietário do capital. Isto devido à existência de poucas grandes empresas, as quais utilizavam predominantemente capitais próprios, recorrendo ao mercado para aquisição de mão-de-obra e terra. Desta forma, o autor salienta ser comum o lucro referindo-se tanto à remuneração do empresário, quanto à propriedade do capital; apesar de Adam Smith e seus seguidores reconhecerem que havia outros elementos fazendo parte dos lucros, além dos juros.

Na escola neoclássica, as contribuições ao debate da questão empresário versus economia foram realizadas até os anos 30 do século XX. Marshall, Edgeworth, Pigou e Clark são exemplos de pensadores neoclássicos que abordaram tal assunto em suas análises econômicas. No entanto, a generalização dos Modelos de Equilíbrio Geral à análise neoclássica resultou no desenvolvimento de modelos que não incorporam a variável empresário. A existência de empresário nas discussões modernas dessa escola é comprometida por alguns aspectos, tais como as pressuposições que fundamentam os modelos de Equilíbrio Geral e a não exploração do processo de ajustamento dinâmico que conduz ao equilíbrio (VAN PRAAG, 1999). Ibrahim e Vyakarnam (2003) enfatizam que, apesar de estar sendo realizados consideráveis refinamentos nos modelos do mainstream, a questão é que a estrutura fundamentada em equilíbrio geral está intacta.

Há diversas críticas na literatura em relação à ausência de abordagem na moderna teoria neoclássica do fator empresário. Para Baumol (1968) a carência de debate sobre tal assunto na escola é resultado da busca de simplificações nas modelagens. O autor salienta que a falta do recurso empresário na moderna teoria neoclássica se dá pelo fato de os modelos serem instrumento de otimização de problemas bem definidos. Desta forma, não é necessária a incorporação de empresários para solucioná-los. O autor afirma ainda que na teoria neoclássica o que se tem é a existência de um grupo de gerenciamento, cujo papel é de uma calculadora passiva reagindo a mudanças exógenas. No entanto, Baumol (1968) aponta que o ponto crítico dessas simplificações está no conceito neoclássico de homo oeconomicus como um mero hedonista.

A discussão de Marshall sobre os empresários é a mais importante dentre os representantes da escola neoclássica que discutiram o assunto (VAN PRAAG, 1999). Em seu tratado sobre Princípios de Economia, Marshall adota a classificação dos fatores de produção como sendo 
quatro; entretanto, o quarto fator é denominado como organização. Para Marshall o empresário tem como funções abastecer o mercado com produtos, bem como prover a sociedade com inovações e progresso. O pensador, em consonância com as pressuposições da teoria neoclássica, assinala que o empresário, ao buscar a minimização de custos, necessita ser inovativo.

Ainda evidenciando o pensamento acerca do empresário nas primeiras gerações da escola neoclássica é oportuno salientar a visão do economista americano John Bates Clark. Este economista conceituava o empresário como tendo a função de utilizar tanto capital, quanto trabalho, conseguindo com que o produto dessa interação de fatores de produção tivesse um valor maior que o custo dos elementos que o compunham (TUTTLE, 1927). Uma questão discutível acerca do conceito de Clark é com o fato de o produto ter maior valor do que seu custo. É evidente que para a formação de lucro esta é uma condição necessária, assim como para a sobrevivência da firma no longo prazo. Entretanto, dependendo da estratégia do empresário, isto nem sempre acontece, como exemplo, citam-se as estratégias de aumento de participação no mercado e a redução do número de concorrentes. Desta forma, a falta de lucro não invalida um agente ser classificado como um empresário.

É destacado na literatura o conceito de Schumpeter acerca do empresário como um inovador, o que implica que nem todo proprietário de empresa é um empresário. Para este pensador, o empresário rompe um estado de equilíbrio e inicia um movimento que resulta em uma posição melhor no final do processo dinâmico (VAN PRAAG, 1999; PAULA et al.., 2000). Segundo Casson (2005), a visão de Schumpeter acerca do empresário é que se trata de um herói motivado por sonho, pela vontade de construir um reino privado e pela necessidade de provar ser superior aos demais. A partir de uma combinação de idéias econômicas e psicológicas, Schumpeter utiliza o empreendedorismo para explicar mudanças estruturais, crescimento econômico e ciclos econômicos (SCHUMPETER, 1961). Eisenhauer (1995) assinala que apesar de serem incontestáveis as contribuições de Schumpeter como economista, na sua definição, um empresário não seria incentivado pelo prêmio econômico. Na visão de Schumpeter são os fatores psicológicos que motivam um indivíduo a ser empresário (SCHUMPETER, 1961).

Brouwer (2002) faz referência à discussão de Max Weber acerca do papel do empresário para o desenvolvimento econômico. A teoria de Weber é de que a ética protestante consiste em um fator de desenvolvimento econômico. Isto seria a explicação do crescimento da Holanda, Inglaterra e colônias americanas com presença de Puritanos e Calvinistas. Para Brouwer (2002), a 
teoria de Schumpeter pode ser vista como uma crítica implícita à teoria de Max Weber acerca da importância da ética Protestante, enquanto o livro de Weber sobre organização econômica e social pode ser reputado como uma crítica às colocações de Schumpeter.

Outro pensador que contribui com a discussão do papel dos empresários na economia é Knigth. A teoria knigthiana pode ser considerada como um refinamento das idéias de Cantillon, uma vez que o autor considera que todos que têm um rendimento incerto, correndo risco ao comprar a um preço conhecido e vender a um preço incerto (PAULA et al.., 2000). Brouwer (2002) enfatiza que Knight esclarece alguns pontos da discussão entre Weber e Schumpeter ao considerar que a incerteza, ao invés da racionalidade de Weber ou da inovação de Schumpeter, é um aspecto importante que norteia a tomada de decisão do empresário. Outro ponto de destaque da teoria de Knigth é a diferenciação de risco de incerteza. Considera-se o primeiro como passível de mensuração, enquanto a incerteza, por desconhecimento da distribuição de probabilidades, não é possível de ser mensurada. Desta forma, o empresário de Knight é aquele que toma decisões (do que e como fazer) assumindo risco. De acordo com Van Praag (1999), outro aspecto de importância está relacionado com a análise das características e das motivações necessárias para se tornar um empresário de sucesso. Este agente garante a remuneração aos demais fatores de produção, sendo a sua remuneração, além do lucro, o prestígio e a satisfação.

Na escola austríaca é oportuno salientar a abordagem de Kirzner acerca do empresário. Para esse economista, o empresário tem uma posição de pivô no processo de mercado. Os empresários buscam identificar oportunidades de lucro, forçando o mercado a tender ao equilíbrio, uma vez que o equilíbrio para a escola austríaca não é atingível (VAN PRAAG, 1999). Skuras e Stathopoulou (2000) enfatizam que a conceituação proposta por Kirzner é mais focada no processo empresarial. Para este economista, empresário é o que identifica oportunidades, não necessariamente organizando os fatores produtivos. A questão chave do conceito proposto por Kirzner é a informação; a existência de assimetria de informação possibilita que indivíduos mais alertas possam realizar lucro. A alertividade desses indivíduos pode ser um fator natural, ou então, em razão da busca por lucro.

A definição proposta por Casson enfatiza o ponto comum de todas as abordagens do conceito de empresário defendidas desde a discussão de Cantillon. Casson (2005) define empresário como o agente tomador de decisões a fim de lidar com novidades e problemas complexos. Para o autor, tomar decisões significa fazer opções bem sucedidas quando não se tem 
disponível nenhum modelo ou regra, ou então, quando informações relevantes não são conhecidas ou são incompletas.

Sintetizando, verifica-se que o conceito de empresário não é único nas ciências econômicas. Analisando as definições propostas pelos pensadores econômicos, nota-se que não existe consenso entre eles a respeito do que seja um empresário. Um aspecto que possivelmente interfere nesta falta de consenso é que se trata de um conceito multidisciplinar. As definições não conseguem refletir esse aspecto, sendo estas conceituadas de perspectivas particulares e assim, a depender da ótica de observação, são deficientes. Conforme enfatizado por Audretsch e Keilbach (2004b) essa variedade de abordagem dos conceitos conduz a diferentes resultados de estudos aplicados. Desta maneira, torna-se relevante definir o conceito buscando-se atender tal aspecto multidisciplinar a fim de possibilitar o planejamento e a implementação de políticas eficientes de capacitação do capital empresarial, bem como entender o seu papel no desenvolvimento. Ainda, a discussão do conceito deve atentar ao fato de não se fundamentar em aspectos relacionados a características comportamentais de indivíduos que dirigem negócios bem sucedidos. O conceito deve analisar os aspectos envolvidos em todas as fases da decisão de se tornar empresário, inclusive os de cunho econômico.

\section{$2.3 \mathrm{O}$ estoque do fator de produção empresário: capital empresarial}

O termo capital empresarial não é comum na teoria econômica, possivelmente pela carência de mais discussões acerca da origem e do papel do empresário na economia. Nos últimos anos, há uma proposta que visa suprir a lacuna das discussões e dos modelos econômicos com relação à ausência dos componentes da atividade empresarial. Tal proposta é a definição do conceito de capital empreendedor e de métodos para mensurá-lo. Considerando-se que o conceito de capital empreendedor é multiníveis e um dos níveis de análise é o individual, usa-se neste trabalho o termo capital empresarial. O conceito de capital empreendedor, bem como sua evolução, está brevemente apresentado neste item, cabendo enfatizar que o capital empreendedor não pode ser entendido como sinônimo do capital empresarial. O capital empreendedor tem enfoque mais amplo, conforme será discutido. Já capital empresarial aqui apresentado é um conceito com foco nas etapas do processo de decisão do indivíduo de se tornar empresário. 
A proposta do capital empreendedor data do século XXI e visa suprir a lacuna com respeito ao relacionamento da atividade empresarial com economia. Os pesquisadores Audretsch e Keilbach (2004a) apresentaram a proposta deste capital conceituando-o como a dotação regional de fatores que incentivam a criação de novos negócios. Os fatores considerados como importantes foram os indivíduos dispostos a tomar risco, o ambiente encorajador (por exemplo, um ambiente inovativo), a existência de uma rede de relações formais e informais, a aceitabilidade social da atividade e a existência de bancos e de capital de investimento dispostos a dividir os riscos e os benefícios envolvidos. Tais autores defendem que os modelos de crescimento econômico podem aumentar seu poder explicativo se passarem a incorporar o capital empresarial nas funções de produção explicativas dos determinantes do crescimento.

O artigo de Audretsch e Keilbach (2004a), que apresenta a proposta do capital empreendedor como uma variável explicativa relevante do crescimento econômico, além de teórico, é também aplicado. Em seu estudo é estimado para 327 regiões da Alemanha uma função de produção do tipo Cobb-Douglas a fim de identificar se o capital empreendedor tem impacto positivo no nível de produção. Esta regressão tem como variáveis explicativas o estoque de capital utilizado no setor manufatureiro, número de empregados passíveis de receber seguro social, número de empregados dos setores privado e público de pesquisa e variáveis para captar o capital empreendedor. Os autores utilizaram três tipos de medidas a fim de captar o capital empreendedor, a taxa de novas empresas abertas, a taxa de novas empresas de alta tecnologia abertas e a taxa de empresas de informação e comunicação abertas. As duas últimas medidas foram utilizadas para analisar a questão de inovação que alguns estudiosos defendem estar relacionada com a discussão sobre capital empreendedor. Um dos resultados encontrados no estudo foi que o capital empreendedor tem maior poder explicativo do que o conhecimento, evidenciando-se, assim, a necessidade de se conhecer os componentes deste tipo de capital.

Na mesma linha de defesa do capital empreendedor foi publicado, também em 2004, outro trabalho que visava ao aperfeiçoamento do conceito de capital empreendedor. Audretsch e Keilbach (2004b) acrescentam que o capital empreendedor é um sub-componente do capital social que estimula a atividade empresarial e inclui fatores legais, institucionais e sociais. Os autores salientam que não pode haver confusão entre os conceitos capital empreendedor e capital social, isto é, não se deve entender que são o mesmo conceito. Um dos pontos que distinguem capital social do capital empreendedor é que alguns fatores do primeiro conduzem ao 
empreendedorismo. O impacto do capital social no capital empreendedor depende de orientação específica do primeiro para estimular o segundo tipo de capital, uma vez que o capital social pode ser direcionado para a manutenção do status quo da sociedade. Já o capital empreendedor tem impactos positivos na atividade empresarial. Desta forma, trata-se de dois tipos distintos de capital, sendo que capital social pode inibir o capital empreendedor, enquanto o capital empreendedor incorpora os aspectos do capital social, que estimulam a atividade empresarial.

Um conceito recente, como o capital empreendedor, passa por diversos aperfeiçoamentos à medida que é apresentado à sociedade científica. Audretsch e Monsen (2007) ampliam a definição considerando que há vários níveis de análise possíveis, mas que se referem a um mesmo conceito, o de capital empreendedor. Os níveis de análise são o econômico, organizacional, time e individual. A análise em nível econômico faz menção aos fatores relacionados ao capital social que promovem a atividade empresarial em uma região econômica ou em uma indústria. Com respeito ao nível de organização, associa-se a fatores organizacionais relacionados ao capital social que influenciam e formam organizações que estimulam a criação de novas unidades de negócios. O nível time está relacionado com fatores interpessoais que estimulam e formam times de gerentes e funcionários que se comportam empresarialmente. $\mathrm{O}$ capital empreendedor em nível individual é definido como os fatores pessoais relacionados ao capital social que influenciam e formam processos de cognição e atitude em empresários, gerentes e funcionários com a finalidade de descobrir, criar e perseguir oportunidades empresariais. Desta forma, apesar de especificar em níveis a forma de abordagem do capital empresarial, o conceito parte da consideração de que o capital empresarial é um sub-componente do capital social.

A visão de que o capital empresarial é um sub-componente do capital social é passível de contestação. Em consonância com esta assertiva, o capital empreendedor é conceituado por Audretsch, Heblich e Monsen (2007) como um fator de produção independente, não como um sub-componente do capital social. Este fator de produção independente combina criativamente e gera os demais tipos de capital. Esta proposta de conceitualização do capital empreendedor vai de encontro com a definição de Jean Baptiste Say, que fala da existência de um fator de produção mais amplo, denominado de indústria humana, ao invés do fator de produção trabalhador. Os autores fazem a ressalva que apesar de ser um fator independente, está associado com interações sociais entre os agentes. O modelo multiníveis é mantido pela proposta de Audretsch, Heblich e 
Monsen (2007), sendo que as definições de Audretsch e Monsen (2007) para os níveis de análise são corrigidas. Elimina-se a definição dos fatores relacionados ao capital social como estimuladores do capital empreendedor, dado que o capital empreendedor é visto como independente. Desta forma, por exemplo, o capital empreendedor em nível individual é definido como aqueles fatores pessoais que influenciam e formam processos cognitivos e atitudes em empresários, gerentes e funcionários de maneira a estimulá-los a descobrir, criar e perseguir oportunidades empresariais. Audretsch, Heblich e Monsen (2007) enfatizam que o indivíduo é o elemento básico da rede social e o capital empreendedor dos indivíduos é entendido como percepção, coragem e atitude. A fonte de energia para a oferta dos demais níveis de análise, ou seja, o time, a organização e a região é o capital empreendedor dos indivíduos. Desta forma, temse que o estímulo do capital empreendedor dos indivíduos acarreta na variação do capital empreendedor em todos os demais níveis. Por fim, é apontado neste estudo que o mesmo impacta a pesquisa atual pela defesa do empresário como o centro da atividade econômica e a fonte fundamental de energia para o sistema econômico.

Adicionalmente à discussão de capital empreendedor encontram-se na literatura trabalhos que apresentam o conceito de capital empresarial. Um dos estudos que trata do conceito de capital empresarial é o de Erikson (2002), que busca investigar o relacionamento entre dois conceitos fundamentais. O primeiro é que capital empresarial é uma função multiplicativa de competência empresarial e compromisso empresarial. Alternativamente, existe também o conceito de que este capital possa ser entendido como o valor presente do comportamento empresarial futuro. Assim, o autor afirma que é plausível a união das visões de capital empresarial, dado que os efeitos da competência e do compromisso empresarial traduzem-se em comportamento empresarial futuro. A parte aplicada do estudo foi implementada por meio de questionários que foram respondidos por estudantes e, assim, o capital empresarial reflete o potencial futuro comportamento empresarial de indivíduos ou time. Uma das considerações do autor é que a partir dos resultados para as instituições sociais e educacionais deve-se focar no treinamento dos componentes da equação que conceitua o capital empresarial, isto é, competência e compromisso empresarial.

O conceito capital empresarial é utilizado no trabalho de Firkin (2001), que propõe uma abordagem teórica fundamentada na definição de capital. O autor apresenta o conceito de capital associado a riqueza monetária, entretanto, faz a ressalva que é possível incorporar elementos não 
monetários ao conceito. Tal consideração torna o emprego de capital mais apropriado para a questão do processo empresarial. Isto porque, segundo o autor, apesar de as questões de cunho financeiro serem geralmente consideradas como aspectos mais sensíveis no processo empresarial, na verdade, as questões não monetárias são as de maior relevância. Como conceito de capital empresarial, Firkin (2001) defende que se trata de uma mistura de várias formas de capital, enfatizando que a conversibilidade do capital de Bourdieu garante a transformação de um tipo de capital em outro. O ponto chave da proposta de Firkin (2001) refere-se à visão de que a análise de um tipo de capital não deve ser realizada de forma isolada; o inter-relacionamento entre os capitais deve ser considerado. Assim, o capital pessoal de um indivíduo, constituído do capital econômico e social, que é composto de network e orientação familiar e capital humano; e capital pessoal, formado por capital humano e cultural, podem ser convertidos para propostas empresariais. Tal conversão é possível, dada a conversibilidade do capital, mas influenciado pela existência de circunstâncias incentivadoras.

Em resumo, verifica-se na literatura correntes que visam tentar corrigir a ausência do empresário e análise do empreendedorismo na economia. Há propostas intituladas de capital empresarial, mas estas podem ser consideradas reducionistas ao focarem-se somente no empresário. A proposta de capital empreendedor, em razão do seu modelo multiníveis, mostra-se mais adequada, apesar de ser ainda um conceito em desenvolvimento. A visão de que o capital empreendedor é um fator independente em que o empresário é a mola propulsora do sistema econômico representa uma proposta refinada e holística. A proposta de capital empresarial pode ser também considerada como um sub-componente do capital empreendedor.

\subsection{Correntes que explicam a oferta de capital empresarial}

Os empresários são a centelha do sistema econômico; assim, a identificação dos aspectos que determinam a escolha de ser empresário ou empregado é um tópico relevante na pesquisa econômica. Tal assunto é multidisciplinar, o que representa maior dificuldade na elaboração de modelos que reflitam tal aspecto, e não apenas abordem o assunto de uma perspectiva particular. Encontram-se correntes que defendem que os empresários nascem empresários, e outras que afirmam ser possível criar empresários. Tais visões são de suma relevância para a implementação de políticas de desenvolvimento, fundamentadas em promoção do recurso empresarial; afinal, se 
empresários nascem empresários, então, conforme assinalado por Boettke e Coyne (2003), as políticas deveriam apenas ter o papel de criar um ambiente institucional propício para a atuação dos empresários. É apresentado no próximo item a citação de algumas correntes que visam explicar a oferta de empresários na economia.

\subsubsection{Modelos de traços}

Em consonância com a visão de que os empresários nascem empresários, a abordagem da psicologia da personalidade fundamenta-se na teoria dos traços para compreender a oferta de empresários. Traço é entendido como qualidade ou característica da personalidade de um indivíduo que se manifesta na maioria dos contextos sociais e pessoais. Assim, busca-se identificar, por meio de testes, quais traços são comuns entre indivíduos que desejam ser ou já são empresários. São diversos os autores que seguem essa linha de pensamento. Como exemplo, citam-se os estudos de Green et al.. (1996), Kon (1996), Brandstätter (1997), Lumpkin e Erdogan (1999), Littunen (2000), e Beugelsdijk \& Noorderhaven (2005).

A linha de abordagem psicológica da existência de empresários assinala que as principais características da personalidade de um empresário são: desejo por independência, locus interno de controle, criatividade, propensão a tomar risco, necessidade de realização, autoconfiança, entre outros. Esses estudos baseiam-se em técnicas de estatística descritiva e de econometria para mostrar que empresários são indivíduos que apresentam uma combinação especial de traços de personalidade, distinguindo-os da maioria da população. Tal afirmativa, com relação à oferta de empresários, é encontrada nos pensadores clássicos como Say, Schumpeter e Knight. Estes colocavam que a oferta de empresários é restrita pelo fato de apresentarem um conjunto de qualidades raras. Schumpeter acreditava que, apesar de os empresários apresentarem uma combinação rara, havia a possibilidade de ensinar os indivíduos que não apresentavam tal conjunto de características a se tornarem empresários.

Há diversas críticas na literatura a respeito da abordagem psicológica da existência dos empresários. Em primeiro lugar, tem-se a questão de causalidade ou de efeito ao se ter um comportamento. Tais estudos não podem afirmar se o conjunto de traços encontrados é a causa ou o efeito de ser empresário. Associado a essa ambigüidade, tem-se ainda que característica não é uma variável medida objetivamente, tratando-se de interpretações das pessoas analisadas. 
Conforme Brandstätter (1997), é assumido que os traços são preferencialmente causa do empreendedorismo. Isto devido a dois fatores: primeiro, ao fato de os indivíduos escolherem e adaptarem o ambiente conforme suas preferências, as quais são influenciadas pela personalidade. Segundo, pelo ambiente ser ajustado e modelado por predisposição genética.

A linha de explicação psicológica do surgimento de empresários busca na genética argumentação para sustentar sua validade. Brandstätter (1997) defende que as diferenças encontradas quando se avaliam os traços dos empresários podem ser entendidas como a causa de $50 \%$ das características de personalidade serem transmitidas por genes. Este campo de pesquisa, interação entre genética e psicologia, vem se desenvolvendo. Os resultados recentes encontrados pelos pesquisadores dessa área revelam que a genética também influencia na personalidade. Entretanto, não é possível definir a preponderância do fator genético sobre os fatores ambientais. É oportuno salientar que a personalidade é resultado tanto do genótipo, isto é, patrimônio genético, quanto do ambiente, não se podendo definir qual dos fatores tem maior importância. Conforme Volpi (2004), o elemento genético da personalidade, que corresponde ao temperamento, não pode ser apreendido, tampouco educado. Segundo o autor, certos aspectos do temperamento podem ser amenizados através do caráter.

A discussão de traços comuns sugerindo a existência de uma personalidade empresarial possivelmente é deficiente para explicar a oferta de empresários. Volpi (2004) enfatiza que embora seja possível encontrarem-se indivíduos com traços semelhantes, a personalidade é única. O autor afirma que a personalidade sustenta-se em uma estrutura biopsicossocial, sendo dinâmica, adaptável e mutável. Assim, ao definir um conjunto de traços como explicativo da oferta de empresários pode-se estar propondo uma explicação para a decisão de ser empresário, possivelmente incompleta. Campbell (1992) ressalta que a visão da escolha de ser empresário ser considerada ou uma capacidade psicológica, como talento musical ou poético, ou um comportamento social desviante, gera uma limitação das explicações, das predições e das políticas que visem encorajar o empreendedorismo. O autor enfatiza que a discussão deve buscar os fatores econômicos que motivem a decisão de ser empresário, em vez de se fundamentar em pressuposições de características pessoais únicas, condições sociais ou preferência por risco.

A influência dos fatores sociais na personalidade é um ponto relevante na discussão acerca da idéia de que empresários nascem empresários, em razão do seu papel na formação da personalidade humana. O estudo de Mead (2001) analisou o comportamento de duas tribos 
indígenas da Guiné com características étnicas iguais e que viviam em um mesmo ambiente. Apesar das similaridades, o comportamento dos membros das tribos é diferente. Encontra-se em uma um comportamento mais hostil e competitivo, enquanto em outra se encontra mais pacificidade e cooperação. Desta maneira, fica evidenciada a relevância na personalidade de aspectos como: cultura, hábitos familiares, grupos sociais, escola, responsabilidade, moral e ética, entre outros.

O trabalho multidisciplinar de Knudsen et al.. (2006) faz referência ao papel do ambiente e de experiências durante a infância no desenvolvimento das habilidades sociais e cognitivas das pessoas adultas. As capacidades cognitivas, sociais e emocionais são apontadas pelos estudos sobre capital humano como relevantes na produtividade econômica de um adulto. A partir da apresentação de resultados de pesquisas, os autores apresentam que um ambiente adverso implica em redução das capacidades cognitivas e sociais dos indivíduos. Entende-se como características de ambiente adverso o baixo nível de renda, pais com nível educacional baixo, pais com problemas mentais, privação social ou negligência, exposição à violência, entre outros. Durante o período pré-natal até os primeiros anos de vida, os circuitos neurais podem ser modificados por experiências, o que ocasionará que alguns genes são ativados ou desativados, ou então ajustados. Essas modificações acarretam mudanças no processamento de informações pelo circuito neural, entre outras. Os autores salientam que traços como gostos por aventura e ansiedade são influenciados pela experiência durante a infância, e não geneticamente. Com o passar dos anos, a flexibilidade de modificação dos circuitos neurais se reduz; desta forma, os autores defendem que para melhorar a qualidade da força produtiva deve-se priorizar investimento em crianças que vivem em ambientes adversos durante o período da infância.

O surgimento de empresários é um processo complexo para ser analisado por um método simples e fixo como o que fundamenta a teoria dos traços. Ainda, a defesa que a oferta de empresários não pode ser alterada é invalidada por estudos como o de Knudsen et al.. (2006), que indicam que traços podem ser modelados por experiências. A aplicação da teoria dos traços para explicar a oferta de empresários tem como resultado um perfil de indivíduo difícil de ser encontrado na sociedade. Em consonância com esse problema, a proposta de Bygrave e Hofer (1991) é que as análises tenham como foco o processo empresarial e não a característica do agente. Desta forma, podem contribuir para o entendimento do surgimento de empresários de 
forma realística, já que o perfil do indivíduo elaborado pela teoria dos traços seria de um super homem especial.

\subsubsection{Modelos de escolha ocupacional}

A corrente que considera que empresários podem ser feitos não define de forma unânime quais fatores influenciam a escolha desta opção em contraste com a de ser funcionário. O desafio dessa linha é identificar quais condições propiciam o aparecimento de empresários. No entanto, há convergência entre os pesquisadores de que é possível estimular a oferta de empresários através de programas de treinamento e políticas de incentivos ao empreendedorismo. Os trabalhos nessa linha já identificaram como fatores que estimulam a existência de empresários o capital, a experiência profissional, o conhecimento (o que fazer, como fazer e por que fazer), a idade, a família, a transferência intergeracional de capital, a existência de rede social, as instituições e estabilidade macroeconômica, entre outros.

Uma abordagem utilizada pela corrente que acredita que a oferta de empresário pode ser estimulada fundamenta-se em modelos de escolha ocupacional. Os modelos de escolha ocupacional têm como pressuposto que os indivíduos escolhem uma ocupação considerando a maximização de uma função utilidade. Esta função tem como argumentos os valores presentes líquidos dos ganhos de um conjunto de ocupações. Blau et al.. (1956) propõem a discussão da estrutura conceitual dos modelos de escolha ocupacional em razão de defenderem que o desenvolvimento de uma teoria científica depende de pesquisa empírica sistemática. Os autores apresentam uma abordagem multidisciplinar conjunta da escolha dos indivíduos por uma ocupação, por até aquele momento as abordagens psicológica, econômica e sociológica avaliarem as variáveis relacionadas aos seus campos de atuação. Tal procedimento, segundo os autores, não explicava a escolha ocupacional, ou então, resultava em defender uma explicação confusa da questão.

Os modelos de escolha ocupacional têm como pressuposto o fato de a escolha ser norteada por dois conjuntos interrelacionados. Um conjunto refere-se à avaliação das remunerações das várias alternativas existentes, e o outro é composto pela avaliação das chances de ser capaz de atuar em cada alternativa. A escolha reflete uma hierarquização entre as expectativas e as 
preferências dos indivíduos. Assim, a maximização do valor esperado da remuneração considera tais conjuntos.

Seguindo a linha de modelagem de escolha ocupacional, Eisenhauer (1995) busca discutir os motivos econômicos que levam um indivíduo a preferir ser empresário a funcionário. O trabalho deste pesquisador busca integrar três escolas de discussão do conceito de empresário na construção do modelo de decisão ocupacional. As escolas são: a de Chicago, representada pela discussão de Knight e Schultz, a Alemã, representada por Schumpeter e a austríaca, representada por von Misses e Kirzner. A proposta do autor é um modelo em que a decisão ocupacional é função da comparação entre a remuneração de ser empresário e o salário de ser empregado e as condições de trabalho assalariado. É discutido que o modelo incorpore um vetor de características pessoais e psicológicas e um vetor de fatores externos, constituído por fatores econômicos preponderantes na escolha. Entretanto, na modelagem o primeiro vetor é desconsiderado por tratar-se de variáveis subjetivas e de difícil mensuração. Desta forma, é avaliado um modelo probit cuja variável dependente é iniciar ou não um negócio que não seja agrícola e, variáveis independentes como o salário, a taxa de desemprego, a riqueza inicial do indivíduo, taxa de juros, seguro-desemprego, condições de trabalho assalariado e idade. Os resultados encontrados são que taxa de juros e idade são variáveis não relevantes para explicar a escolha. Os autores apresentam algumas possíveis justificativas para esse resultado como proxies ruins para avaliar a renda futura descontada ou os empresários não terem um horizonte de planejamento de longo prazo. As demais variáveis analisadas foram estatisticamente significativas para explicar a probabilidade de escolha em ser empresário.

A incorporação de parâmetros relacionados a aspectos específicos aos modelos de escolha ocupacional busca avaliar a influência de tal aspecto na escolha dos indivíduos. Clemens (2002) avalia a influência da preferência por status social na escolha ocupacional sob condições de risco. Considerando os ganhos de ser empresário e a renda esperada, o indivíduo escolhe entre ofertar unidades de trabalho e receber um salário com menor risco envolvido ou então, ter uma renda variável e tolerar todos os riscos envolvidos na produção. A autora mensura a preferência por status social através da renda relativa esperada, que é a razão entre a renda individual esperada e a renda média agregada. Desta maneira, uma razão alta implica em um maior nível de utilidade derivada do status social. Os resultados obtidos por estatística comparativa indicam que em sociedades com maior grau de aversão ao risco um número maior de indivíduos escolhe ser 
empresário quando comparado à sociedade risco neutro. Em sociedade risco neutro o status não afeta o equilíbrio de distribuição entre empresários e funcionários. Há um trade-off positivo entre status e risco, e status e escolha por risco e a renda média e a utilidade esperada são maiores em sociedades que preferem status social.

A questão de avaliar a relevância da restrição de crédito na escolha ocupacional é testada no trabalho de Evans e Jovanovic (1989). Sob consideração da diferença de conceito de empresário defendida por Knigth e Schumpeter, os autores buscam verificar o papel da restrição de crédito em um modelo de escolha ocupacional. Os resultados das regressões estimadas validaram a hipótese de que a restrição de capital é um fator limitante para os indivíduos optarem por ser empresários. Os indivíduos de famílias mais ricas são mais propensos a ser empresários. Os autores argumentam que este resultado não indica que riqueza implica em melhores empresários, mas sinaliza que o capital é essencial para iniciar-se um negócio. A influência da restrição de crédito na escolha ocupacional é citada pelos autores como uma explicação para os resultados encontrados no estudo de Evans e Leighton (1989) cuja probabilidade de ser tornar empresário é constante, considerando-se a idade.

Uma proposta teórica é construída e testada por Blanchflower e Oswald (1998) com vistas a discutir os fatores que influenciam na oferta de empreendedorismo. Os autores ressaltam que tal tópico é reconhecido como importante na literatura, entretanto, é pouco compreendido. O modelo teórico desenvolvido no trabalho é uma abordagem microeconômica da escolha de ser empregado ou funcionário por indivíduos que têm restrição de capital. O estudo foi realizado com uma amostra de pessoas que nasceram na Grã Bretanha entre três e nove de março de 1958, e foram entrevistados nas idades de 7, 11, 16, 23 e 33 anos. Os resultados econométricos do modelo proposto indicaram que as variáveis psicológicas têm pouca importância na explicação dos indivíduos que optam por ser empresários. O empecilho de se tornar empresário é a restrição de crédito, sendo que o recebimento de herança aumenta a probabilidade de escolha de ser empresário. Outro resultado é que o nível de satisfação, tanto profissional quanto pessoal, é maior entre os que se tornaram empresários.

A análise da influência de variáveis relacionadas à atividade ocupacional na opção de ser empresário é a proposta do trabalho de Douglas e Shepherd (2002). Os autores defendem que a escolha ocupacional é resultado da utilidade esperada da renda e da utilidade, ou desutilidade, do esforço de trabalho, exposição ao risco, independência e outras condições do trabalho. Assim, 
eles avaliam a influência da renda, o esforço de trabalho, risco e independência através do método de análise conjunta e por regressões. Esforço de trabalho é conceituado como o gasto de esforço físico e mental ao exercer uma função, sendo mensurado por horas de trabalho e intensidade de trabalho. A hipótese é que indivíduos mais tolerantes ao esforço têm maior probabilidade de se tornar empresários. Com relação ao risco, eles defendem que uma maior tolerância a risco implica em menor desutilidade quando o indivíduo é exposto a esse risco. Os autores citam o resultado do trabalho de Rees e Shah (1986) que encontram que a variância dos rendimentos dos empresários é cerca de três vezes maior que a de um funcionário. Desta forma, Douglas e Shepherd (2002) têm como hipótese que uma maior tolerância ao risco aumenta a probabilidade de um indivíduo ser empresário. A tolerância ao risco é refletida por uma menor taxa marginal de substituição entre risco e renda quando se compara à taxa de uma pessoa avessa ao risco. Os resultados indicam que renda, risco e independência têm influência na escolha, sendo que a renda tem maior influência. Os indivíduos que preferem maiores riscos e mais autonomia são mais propensos a ser empresários. O esforço não foi relevante para explicá-los, o que possivelmente reflete que os indivíduos esperam que maior renda implique em maior esforço.

O estudo de King (1974) visa incorporar à análise de escolha ocupacional dois aspectos que se inter-relacionam: o grau de aversão ao risco e a riqueza familiar. No modelo de escolha ocupacional avaliado a renda é uma variável aleatória, assim, o elemento risco é incorporado. O autor defende a incorporação do elemento risco em razão da variância de renda dentro de um grupo educacional ser maior do que a variância entre grupos, controlando idade. Tal diferença é ressaltada pelo autor e justificada como reflexo da diferença de habilidade; entretanto, os escassos estudos empíricos não comprovam a hipótese. O resultado do estudo de King (1974) revela que as ocupações com maior exposição ao risco oferecem maiores rendas e indivíduos de famílias ricas optam por ocupações de maior risco. Estes resultados sugerem a relevância da estrutura familiar e a transferência de desigualdade entre gerações. $\mathrm{O}$ autor assinala que a estrutura familiar possivelmente condiciona a escolha ocupacional de forma independente das forças de mercado. Ele sugere que seja investigado o relacionamento entre aversão a risco e riqueza da família. Outro ponto ressaltado por King (1974) é que o mecanismo de perpetuação das desigualdades de renda opera através da existência de imperfeições de mercado e pela riqueza familiar. As imperfeições de mercado acarretam em variação na quantidade e na qualidade da educação, enquanto a riqueza familiar influencia na preferência ocupacional. 
Os modelos de escolha ocupacional podem ter sua modelagem simplificada, como assinalou Campbell (1992). O autor propôs um modelo similar ao modelo de migração de Todaro e o modelo de decisão empresarial de Casson sob a consideração que apesar de outros fatores serem relevantes, a discussão dos determinantes econômicos deve ser realizada. A pressuposição do autor é que os trabalhadores também correm riscos, assim, a renda líquida esperada ao se optar por uma ocupação é determinada pela diferença entre o produto da probabilidade de sucesso de ser empresário e a renda média do empresário; e o produto da probabilidade do tempo de permanência como funcionário e o salário médio. Os resultados da modelagem sugerida pelo autor foram obtidos por estática comparativa e revelam que a variação da probabilidade de sucesso, ceteris paribus, resulta em variação do incentivo ao optar-se por ser empresário. O efeito da variação da probabilidade de sucesso e do diferencial entre renda de empresários e funcionários, na opção ocupacional, depende do comportamento com relação ao risco dos indivíduos. Os indivíduos avessos ao risco deverão ser mais afetados pela variação da probabilidade de sucesso, enquanto tal variação não sortirá tamanho estímulo nos indivíduos propensos ao risco. A variação no diferencial entre a remuneração de empresário e de funcionário acarreta em maior impacto na decisão dos indivíduos avessos ao risco em se tornar um empresário.

Na literatura econômica há diversas críticas à modelagem de comportamento fundamentada em funções de utilidade. Pelaez e Sbicca (2000) assinalam que um aspecto a ser questionado é a fundamentação da racionalidade maximizadora no individualismo metodológico. O individualismo metodológico é uma teoria em que o homem é a unidade de análise fundamental. Desta forma, se o sistema social é considerado como a soma dos indivíduos que o compõem, os efeitos das interações entre os indivíduos são abstraídos das análises. Tal visão social implica em reducionismo teórico. Os autores ressaltam que a escolha racional, ao ser vista da ótica do agente individual, não considera as forças sociais que influenciam no comportamento do agente. Ainda, a teoria é deficiente por não discutir como as preferências são formadas, uma vez que os agentes são maximizadores de suas preferências. Entretanto, os mesmos enfatizam que não se pregoa o holismo, mas a seleção dos determinantes do comportamento econômico que explicam o fenômeno. Assim, como o comportamento econômico não é somente influenciado pelo desejo de otimizar, outros aspectos devem ser considerados. 
A racionalidade limitada é uma abordagem considerada como um aspecto que a teoria deveria ter como pressuposto. Pelaez e Sbicca (2000) citam que Simon (1980) ressaltava a deficiência da teoria neoclássica para modelar comportamentos, em que o tomador é influenciado por percepção e cognição. A teoria neoclássica, segundo o autor citado, é uma teoria de um indivíduo que escolhe entre alternativas fixas e conhecidas, além das conseqüências das escolhas serem também conhecidas. Desta forma, o avanço na teoria teria como pressuposto que as alternativas não são dadas e que as conseqüências das alternativas nem sempre são conhecidas. Assim, dada a falta de conhecimento dos agentes, estes têm uma racionalidade limitada, o que implica na busca de soluções satisfatórias e não necessariamente ótimas.

Um conceito sugerido como relevante na análise da decisão de ser empresário em detrimento de ser funcionário é o de utilidade processual. A utilidade processual é a utilidade oriunda do processo que leva ao resultado, assim, o empresário não obtém utilidade unicamente da renda, mas também do processo que resulta na renda. Ou seja, a liberdade proporcionada por ser empresário é também um fator determinante na escolha. Dessa forma, pode haver indivíduos que mesmo podendo ser empresários escolherão ser funcionários por preferirem estar em níveis hierárquicos. Esse conceito é discutido por Fuchs-Shündeln (2005), que busca em seu estudo analisar se as preferências que norteiam a utilidade processual de empresários são homogêneas. Entretanto, seus resultados não fornecem evidência que a preferência processual tenha um papel significativo na escolha de ser empresário. Mas, o autor sugere que as pesquisas nesse sentido sejam aprofundadas. Considerando as limitações da abordagem da utilidade como somente derivada do resultado, tal proposta representa um avanço teórico a ser considerado.

A teoria da utilidade esperada é assinalada por Bianchi e Muramatsu (2005) como deficiente para explicar vários tipos de comportamentos econômicos. No trabalho, as autoras discutem a necessidade de aperfeiçoamento teórico para avaliar escolhas denominadas de planos e compromissos. A partir da crítica de que a teoria convencional é fundamentada em um conjunto mínimo de axiomas de racionalidade, a proposta do trabalho é um modelo de escolha em que é possível um tratamento sistemático da ordenação das preferências e incorporação de objetivos imensuráveis. As autoras discutem que as decisões humanas podem ser influenciadas por questões como preferências morais. Desta forma, a visão tradicional de utilidade advinda somente da preferência por auto-interesse é superada por um modelo lexicográfico em que as preferências são meta-ordenadas. Entretanto, as autoras salientam que há dificuldades 
relacionadas com a tratabilidade formal. Apesar da diferença de assuntos, Filler (1986) diz que a escolha ocupacional não reflete somente a maximização de utilidade, reflete também a possibilidade de acesso à ocupação. $\mathrm{O}$ autor assinala que fatores como raça, gênero e classe social são determinantes da escolha ocupacional. No estudo de Filler (1986) há discussão acerca do gênero, que o autor defende que são necessárias maiores evidências para ser vista como uma questão de discriminação.

A interação entre economia e psicologia, denominada de economia comportamental, é um campo que ressalta as limitações da abordagem teórica tradicional da economia. Vigna (2007) assinala que na economia os modelos comportamentais são simples, mas como pressupostos rigorosos. Os estudos de economia comportamental vêm demonstrando que os agentes divergem das atitudes consideradas como padrão. Vigna (2007) enfatiza que os principais aspectos que infringem a realidade são a preferência não padrão, crença não padrão e tomada de decisão não padrão. Os aspectos que indicam que a preferência é não padrão devem-se a: questão do tempo, autocontrole, atitude em relação ao risco e questões de cunho social. Com relação à crença tem-se a influência da autoconfiança, lei dos números pequenos e viés de projeção. No tocante a tomada de decisão tem-se a influência da atenção limitada, efeito de menu, persuasão, pressão social e emoção, que modificam este comportamento, portanto, a realidade nem sempre condiz com o que a economia assume em seus modelos. Vigna (2007) cita diversos experimentos laboratoriais conduzidos que testam as hipóteses da teoria econômica e tem este resultado como, por exemplo, o de Táler, em que os indivíduos são tempo-incoerentes, o de Charness e Rabin, que mostram a preocupação pelo bem-estar de outros, o de Kahneman e Tversky, que demonstram que a atitude para risco depende da disposição e de pontos de referência. O autor cita ainda os estudos em que a racionalidade é violada, como o de Camerer e Lovallo, em que a superestimação da habilidade é a razão da violação, e o de Read e van Leeuwen, em que a superestimação da situação no momento da decisão é o motivo da não racionalidade pressuposta. Assim, como são resultados de experimentos, o autor salienta que as situações de mercado são, em várias situações, afetadas por estes comportamentos, o que valida a necessidade de reavaliação dos modelos econômicos. A integração entre economia e psicologia parece ser a solução para a construção de modelos mais realísticos.

Em resumo, a aplicação da abordagem da teoria de escolha ocupacional para analisar a decisão de ser empresário é passível de críticas. Tais críticas advêm da interação entre economia 
e o caráter quantitativo desta abordagem. Ao formular funções matemáticas para explicar o comportamento humano, a complexidade da escolha é abstraída. Tal abstração resulta em explicações incompletas, podendo até mesmo ser errôneas. Assim, uma ciência como a economia, que visa compreender o processo de escolha dos indivíduos dado incentivos, afasta-se do seu objetivo.

\subsubsection{Modelos ambiente-característica dos indivíduos}

A abordagem com ênfase em questões do ambiente e características de formação e situação dos indivíduos é uma alternativa para tratar do problema de escolha de ser empresário. Mazzarol (1999) assinala que o papel do ambiente é uma abordagem de maior viabilidade para tratar desta discussão. O autor ressalta que a proposta de enfatizar a análise do ambiente para discutir o assunto está associada com a teoria econômica. A decisão de se tornar empresário, tanto em mercados que tendem a ser perfeitos quanto imperfeitos, ocorre se no longo prazo houver expectativa que os lucros excedam os custos marginais médios. A perpetuação desse cenário é resultante da atuação de forças exógenas que resultam em alterações autônomas do ambiente. Assim, o surgimento de empresas é resultante de forças externas e de informação. Ou seja, o ambiente, bem como os atributos que permitam o entendimento de informações, são determinantes na opção por ser empresário.

A falta de consenso dentre os pesquisadores da linha que considera que a oferta de empresários pode ser estimulada resulta em trabalhos que testam a influência de várias variáveis. Esses trabalhos buscam identificar se a variável analisada influencia ou não na origem e nos fatores que afetam o capital empresarial. Tais pesquisas, em geral, utilizam para as análises métodos econométricos ou de análise fatorial a fim de identificar a significância estatística das variáveis na oferta de empresários.

Há autores que, buscando abordar o assunto de forma multidisciplinar, consideram que a oferta de empresário é resultado da interação de vários fatores. Um exemplo de trabalho que segue essa suposição é o de Cuevas e Carrasco (2001). Os autores ressaltam que os determinantes da oferta empresarial são: características pessoais, contexto econômico, contexto social e familiar, formação e experiência profissional e ação institucional. O ponto crítico do trabalho é determinar relevantes variáveis que sejam relacionadas com as características pessoais. Conforme 
já discutido, não se pode estabelecer se aspectos enfatizados pelos autores como locus interno de controle, iniciativa, autoconfiança, motivação, persuasão, capacidade de negociação, entre outros, são a causa ou o efeito de na escolha de ser empresário.

Um exemplo de trabalho que visa identificar os determinantes que incentivam a oferta de empresários é o de Van Praag e Van Ophem (1995). Os autores partem da pressuposição de que oportunidade e disposição são condições necessárias e, juntas, são condições suficientes para que um indivíduo opte por ser empresário. Nesse trabalho, define-se oportunidade como a possibilidade de se tornar um empresário, caso deseje e, disposição como avaliação do indivíduo ser empresário versus ser funcionário, em situações idênticas. A variável oportunidade foi representada por capital inicial, habilidade empresarial e ambiente macroeconômico. Como resultado, entre outros, encontraram que oportunidade é o gargalo para o aumento da oferta de empresários. Os autores inferem que é possível, através de um modelo educacional, estimular o capital empresarial. Tal conclusão é fundamentada ao se observar a substitubilidade entre capital e habilidade.

A educação é uma variável discutida na literatura acerca da sua influência na variação da oferta de empresários. Um modelo educacional voltado para estimular a decisão de ser empresário é visto como uma forma eficiente de estimular o crescimento do número de empresários, considerando-se que ser empresário não se trata de uma condição inata. Entretanto, Machaba e Lazenby (2005) chamam a atenção para a questão de os modelos educacionais existentes normalmente ensinarem as crianças que tudo no mundo pode ser agendado, assim, a lealdade e a passividade são premiadas. Tais fundamentos fazem com que as crianças sejam inibidas quanto à opção de empreender.

A necessidade de ajustamento dos currículos escolares do Brasil é um ponto há muito discutido na literatura. Tal mudança é ainda mais relevante para a educação rural. Peres (2005) salienta o problema com relação à qualidade da educação formal nos meios rurais do Brasil. A baixa qualidade do ensino nas escolas rurais acarreta a formação de um recurso empresarial com formação formal deficiente, ou então, em aceleramento do processo de migração. Algumas crianças mudam para as cidades a fim de ter educação de melhor qualidade. Considerando a baixa taxa de migração para zonas rurais, há perda de recurso com capacitação.

Os currículos das escolas também representam um problema para a capacitação de empresários rurais. Peres (2005b) enfatiza também que outro problema com respeito à educação 
formal rural é a falta de foco no desenvolvimento de elementos que preparem os alunos para serem empreendedores. Albuquerque (1985) chama a atenção para a necessidade de adaptação dos currículos escolares dos cursos de administração com ênfase rural a fim de reduzir o gargalo administrativo. Segundo o autor, a falta de capacidade administrativa nos estratos médios de produtores rurais é um dos problemas mais visíveis vivenciados na atividade agrícola. Desta forma, tem-se que dado o cenário de mudanças pela qual o meio rural passa, o recurso empresarial agrícola brasileiro encontra dificuldade para gerir o negócio sustentavelmente em razão de carência de conhecimento, habilidade e atitude.

Postigo e Tamborini (2005) discutem o papel da educação empreendedora nas universidades argentinas. Os autores, a partir de entrevistas, buscaram analisar no país a evolução e o estado atual da educação empreendedora. Como resultados encontram que se trata de uma estratégia de longo prazo, mas com efeito positivo no sentido de melhorar a imagem da sociedade acerca dos empresários e na difusão de modelos de gestão. Os autores enfatizam que uma das conseqüências da implementação de programas de educação empreendedora é a redução do custo de oportunidade de seguir a carreira de empresário.

A relevância do fator educacional na decisão e no desempenho do capital empresarial pode estar associada à qualidade do capital humano. Klein e Cook (2006) propõem que as teorias de Schultz sejam analisadas, pois podem trazer contribuições para o questionamento teórico do empresário na economia. Schultz (1975) considera que a habilidade empresarial é uma forma de capital humano, conseqüentemente, pode ser aumentada por educação, treinamento e experiência. O autor afirma que uma forma de aumentar o estoque de capital empresarial seria através de migração de pessoas com experiência e habilidade empresariais. Ainda, Schultz exemplifica citando o caso da agricultura brasileira, em que os japoneses têm mais sucesso que os agricultores brasileiros, por serem mais educados e terem maior habilidade para lidar com cenários em que há modernização.

O efeito da educação no desempenho dos empresários é controverso nas pesquisas sobre os fatores que afetam o capital empresarial. Van der Sluis e Van Praag (2004) revisaram diversos trabalhos nessa linha e constataram que há um problema de viés de estimação nos estudos. Os vieses identificados resultam da existência de um relacionamento endógeno entre educação e performance e o fato de os modelos não incorporarem variáveis não observáveis como habilidade e motivação. Os autores propõem diversas estratégias para tratar os vieses identificados nos 
estudos reportados. Os resultados encontrados pelos autores foram, entre outros, que os maiores retornos em razão de educação dos empresários não constituem um tipo de prêmio de risco e educação é um instrumento importante para influenciar os empregados e a performance dos empresários. Outra conclusão que os autores citam ser fundamentada no trabalho de Parker e Van Praag (2004) é que o desempenho dos empresários, em razão do maior nível educacional, parece aumentar se houver restrição de capital. Os autores justificam tal assertiva porque o fator educação reduz as restrições ao acesso de capital e tem efeito direto na performance dos empresários.

O fator cultural também é destacado na literatura como de relevância para explicar as origens e o desempenho do capital empresarial. Mehra (2002) enfatiza que o espírito empresarial dos produtores rurais indianos é influenciado pela sua rede de comunicação e pelo contexto sócio-cultural das vilas indianas. Davidsson e Wiklund (1995) citam diversos trabalhos na literatura que enfatizam que, aproximadamente, 70 \% da variação da oferta de empresários são explicadas por diferenças de características econômicas e sócio-demográficas entre as regiões. Tal ponto remonta à discussão de Max Weber sobre desenvolvimento econômico e características culturais da sociedade.

O conhecimento dos fatores culturais que influenciam no capital empresarial é relevante para a elaboração e a implementação de políticas que visem ao estimulo deste tipo de capital. Os valores de uma sociedade são difíceis de ser mudados, assim, se esses valores tiverem maior influência, a efetividade das políticas será reduzida. Entretanto, se crenças for um aspecto preponderante, a implementação de políticas não será prejudicada, uma vez que é possível mudar uma crença mais facilmente que um valor. Davidsson e Wiklund (1995) buscam investigar essa questão na Suécia, entretanto, como as diferenças culturais são pequenas no país, não encontram essas variáveis como significante na explicação da oferta de empresários. Todavia, considerandose a diversidade cultural do Brasil, esse aspecto possivelmente tem implicações relevantes na discussão sobre as origens e os fatores que afetam o capital empresarial do país.

A migração merece destaque como determinante do capital empresarial, principalmente, em países como o Brasil, que apresentam intensos fluxos migratórios. NDoen et al.. (2005) discutem a questão de migração entre empresários para países em desenvolvimento. Os autores visam explicar a migração de empresários fundamentados em uma abordagem estrutural e cultural. Tal abordagem considera que a escolha de empresários por determinada área é influenciada por 
fatores como o grau de competição, o acesso ao mercado e ao capital, a concentração de nicho de mercado, a cultura local, a rede de contato, a experiência empresarial e migratória, a idade, a educação e o período de permanência. Ou seja, a opção dos empresários em migrar é influenciada pelo capital empresarial da região. Dessa forma, tem-se uma relação bidirecional quando há bons empresários migrantes em uma região, uma vez que fatores estruturais e culturais da região atraíram os empresários e a região apresenta capital empresarial de boa qualidade em razão de ter bons empresários.

Nas discussões acerca do recurso empresarial a idade dos empresários teria influência na oferta desse fator de produção. Dollinger et al.. (2005) realizaram um estudo exploratório sobre empresários comparando empresários jovens e mais experientes e encontraram que a idade afeta a tomada de decisão e o desempenho dos empresários. Os autores discutem em um contexto americano não agrícola que o número de pessoas não jovens que estão se tornando empresários vem aumentando. Tal aspecto é uma questão que deve ser investigada a fim de se determinar o comportamento e as conseqüências do ingresso desse perfil de empresários. Desta forma, idade é uma variável relevante para a análise do capital empresarial. Lauwere et al.. (2002) estudaram o capital empresarial agrícola holandês considerando que a orientação social, quando comparada ao objetivo de crescimento, é mais importante para o desempenho. Os autores encontraram que os empresários rurais mais idosos apresentam maiores níveis de orientação social quando comparados aos mais jovens.

A família é outra variável avaliada na literatura que visa identificar o que faz um indivíduo ser empresário. A questão familiar é relevante tanto pela transferência de capital humano quanto de capital não humano. Lentz e Laband (1990) chamam a atenção para a questão de desempenho empresarial e herança. Eles apresentam evidências de que a segunda geração de empresários de uma família apresenta vantagens comparativas em relação à primeira. Outro ponto é que dada a formação e a experiência formal serem, em certo grau, substituíveis por experiência informal tem-se que as taxas de retorno da educação para empresários podem não ser altas. Os autores assinalam que no caso rural, a exposição das crianças à atividade dos pais é ainda maior, em razão de as crianças terem quase total acesso ao local de trabalho dos pais. Segundo Lentz e Laband (1990) a transferência de capital físico tem menor importância que a transferência do capital humano. Essa discussão é de relevância para se analisar o capital empresarial para a 
agricultura no Brasil, já que há significativo número de empresários rurais que são oriundos de famílias de proprietários rurais.

Risco e incertezas são pontos críticos da atividade empresarial, o que acarreta ser necessário incorporar tais variáveis em modelagens que visem analisar a oferta de empresários. Sonkkila (2002) define incerteza referindo-se a circunstâncias nas quais as conseqüências das decisões não são conhecidas precisamente pelo tomador de decisão, enquanto risco refere-se a fatores que podem trazer prejuízos em conseqüência da decisão ser realizada em um cenário de incerteza. O autor defende que os produtores rurais enfrentam riscos de produção, mercado, financeiro, tecnológico, acidente, institucional e humano. Na literatura sobre empresários há controvérsias se o empresário é um individuo avesso ou não ao risco. Diversos trabalhos defendem que os empresários não são indivíduos tomadores de risco, dado que um bom empresário avalia todos os riscos envolvidos na atividade para decidir ou não entrar, bem como agir de forma a minimizar as possíveis perdas. Ainda, com respeito à discussão de empresário e risco tem-se a crítica de Schumpeter ao conceito de Knigth. Skuras e Stathopoulou (2000) assinalam que Schumpeter argumenta que o conceito knigthiano é deficiente por não distinguir empresário e proprietário do recurso produtivo. Desta forma, a questão do risco toma relevo na conceituação de empresário proposta por Knigth, quando na visão schumpeteriana o risco não é uma variável relevante, a menos que empresário e proprietário do fator produtivo seja o mesmo indivíduo.

A proposta de Schultz de relacionar o empreendedorismo com a teoria do capital humano contesta a visão de relacionamento entre risco e empresário (SKURAS e STATHOPOULOU, 2000). De acordo com os autores, este economista fez algumas críticas à discussão acerca de empresário, como a questão do conceito ser restrito a um homem que realiza negócios, a desconsideração das diferenças alocativas entre os empresários, entre outros. Schultz defende que o empreendedorismo é a habilidade para lidar com o desequilíbrio. Em consonância com sua proposta teórica, Schultz enfatiza o papel da educação na melhora da habilidade de percepção e reação a situações de desequilíbrio. Outro ponto assinalado é a discussão de Shultz quanto à visão da remuneração dos empresários ser entendida como um prêmio ao risco incorrido. Skuras e Stathopoulou (2000) citam que, na visão de Schultz, a ligação entre risco e empresário é falha, pois outras pessoas que não são empresários podem também assumir alto nível de risco e incerteza. 
Considerando-se que a percepção quanto a risco é um aspecto relevante na determinação da decisão de ser empresário ocorre dificuldade na mensuração da propensão a risco dos agentes. De acordo com Dacorso (2000) há duas teorias para se buscar mensurar a tolerância a risco pelos agentes: a teoria da utilidade esperada e a teoria da perspectiva. O autor cita a sugestão de Clemens (1996), a qual é fundamentada na teoria da utilidade esperada e é simples de ser aplicada. Tal sugestão é avaliar a resposta à seguinte pergunta: Quanto o agente estaria disposto a arriscar, tendo $50 \%$ de chance de triplicar o seu dinheiro (recuperar o dinheiro investido e receber o dobro de prêmio) e 50\% de chance de perder tudo o que investiu? A propensão é representada pelo maior valor que o agente está disposto a arriscar.

Em síntese, tem-se na abordagem microeconômica da discussão sobre as origens e os fatores que afetam o capital empresarial uma corrente que explica a oferta de empresários sob uma ótica psicológica. A análise dos resultados das pesquisas dessa corrente indica a existência de um indivíduo dotado de qualidades excepcionais, dificilmente encontradas no mundo real. Alternativamente, há a abordagem de que é possível, através de estímulos, aumentar quantitativa e qualitativamente a oferta de empresários. Arzeni et al.. (2001) citam diversos autores na literatura que defendem que a variação da oferta empresarial agrícola deve se fundamentar em quatro fatores chaves. Esses fatores são o capital humano, o capital físico e financeiro, a existência de instituições de mercado e ambiente político favorável.

\subsubsection{Modelos de intenção empresarial}

A psicologia social dá suporte a uma das correntes de pensamento que buscam entender e predizer a escolha de ser empresário. As pesquisas em intenção da psicologia social são utilizadas por alguns autores tanto em trabalhos de escolha ocupacional em geral quanto em modelos específicos em empreendedorismo. Na literatura reportada, os trabalhos que se fundamentam na estrutura teórica de intenção utilizam a abordagem de Ajzen e/ou de proposta de Shapero.

A justificativa para se utilizar os modelos de intenção é que optar por desempenhar atividades empresariais é um comportamento planejado. Em geral, as pessoas analisam diversos fatores antes de iniciar seus negócios. Na literatura psicológica, intenção tem provado ser o um preditor parcimonioso de comportamento planejado, principalmente se o comportamento é raro, difícil de ser observado, ou envolve tempo para se manifestar. De acordo com o autor, 
empreendedorismo é um exemplo de opção ocupacional que modelos de intenção têm um bom ajustamento.

O conceito de intenção mais comumente encontrado é de que se trata do grau de comprometimento dos indivíduos a fim de alcançar um comportamento orientado futuro. Aplicado ao âmbito empresarial, o significado de intenção é um comportamento específico orientado para se iniciar um negócio. A relação entre intenção e determinantes e conseqüência está apresentada na Figura 4.

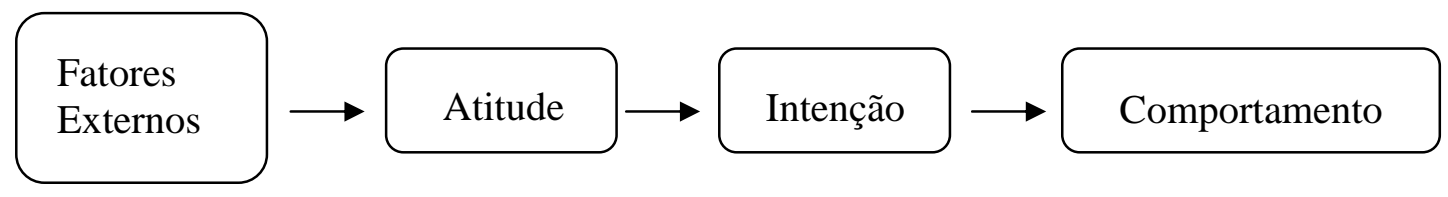

Figura 4 - Intenção e variáveis que a formam e derivam

Fonte: Elaboração da autora

A intenção é a variável chave nos modelos que visam explicar situações práticas consideradas que exigem uma decisão anterior, isto é, representam um comportamento planejado. Observa-se na Figura 4 que a intenção é considerada neste seqüenciamento como um preditor robusto de comportamento. As atitudes para se atingir um comportamento afetam primeiramente a intenção; assim, o comportamento é influenciado indiretamente por atitudes. Ainda, forças exógenas têm um impacto em comportamento e intenções de forma também indireta por meio das atitudes. O modelo atitude-intenção-comportamento dá fundamentação a alguns estudos que visam entender a preferência ocupacional. Um exemplo é a utilização da teoria do comportamento planejado de Ajzen nos trabalhos que visam entender a escolha profissional. Este autor formulou uma teoria do comportamento planejado que propõe que três constructos relacionados à atitude explicam a intenção. Na Figura 5 é apresentado o modelo de intenção fundamentado na proposta de Ajzen. 


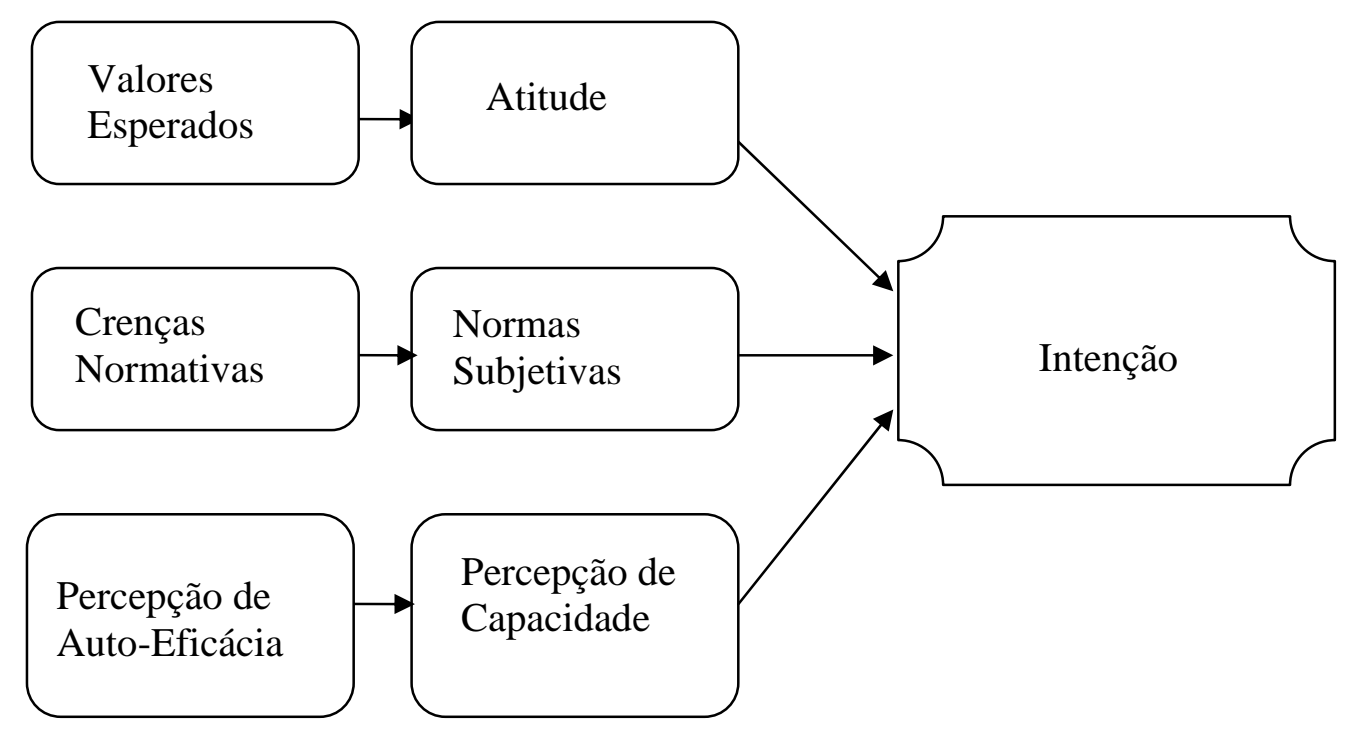

Figura 5 - Teoria do comportamento planejado de Ajzen

Fonte: Krueger, Reilly e Carsrud (2000)

A intenção no modelo de Ajzen é formada por três constructos e estes são determinados por outros três elementos. Krueger, Reilly e Carsrud (2000) apresentam um resumo dos determinantes da intenção na proposta de Ajzen. Segundo os autores, o constructo atitude visa incorporar o desejo de ter um determinado comportamento e que é determinado por expectativas e crenças acerca do impacto dos resultados oriundos de um comportamento. Com respeito ao elemento normas subjetivas o objetivo é considerar no modelo a opinião das implicações em se ter um determinado comportamento, como por exemplo, a influência da família na escolha de um indivíduo por uma determinada ocupação. As normas são subjetivas; assim, são resultado do incentivo de pessoas influentes. Os autores citam Shapero (1982), que enfatiza que poucos estudos enfatizam as normas e os valores providos por membros do círculo de influência, a maioria dos trabalhos focam no fluxo de recursos e de informações. Por último, Krueger, Reilly e Carsrud (2000) apresentam o conceito e a importância da incorporação nos modelos do constructo percepção de capacidade e percepção de autoeficácia. Estes elementos buscam adicionar a questão de percepção de controle comportamental, isto é, percepção da capacidade de executar um comportamento. Os autores citam vários trabalhos na literatura que enfatizam a importância do reconhecimento pelos indivíduos da sua autoeficácia para o desempenho de atividades empresariais. Em um exemplo, cita-se o trabalho de Bandura (1986), em que a 
autoeficácia é definida como o começar e persistir com um comportamento em situação de incerteza, ter objetivos ambiciosos e redução do medo de fracasso.

A proposta de Shapero é bastante similar ao modelo de Ajzen, entretanto, foi adaptada com a pretensão de ser mais apropriada ao contexto empresarial. Krueger (1993) assinala que o modelo de evento empresarial de Shapero assume duas premissas, a primeira, que iniciar um negócio depende da percepção de uma oportunidade crível e ainda, é necessário alguma situação que force este comportamento. Krueger, Reilly e Carsrud (2000) explicam que o modelo de Shapero assume que o comportamento humano é inercial até que algum evento interrompa ou force a inércia. Os autores sintetizam o modelo de Shapero a partir da citação de Katz, que afirma que diante de forças que causem distúrbio à inércia os agentes escolhem a melhor oportunidade dentre um conjunto de alternativas. A escolha de comportamento é função da viabilidade das alternativas e da propensão a agir. A viabilidade depende da interpretação de que o comportamento é desejável e possível. Na Figura 6 é apresentado modelo de Shapero.

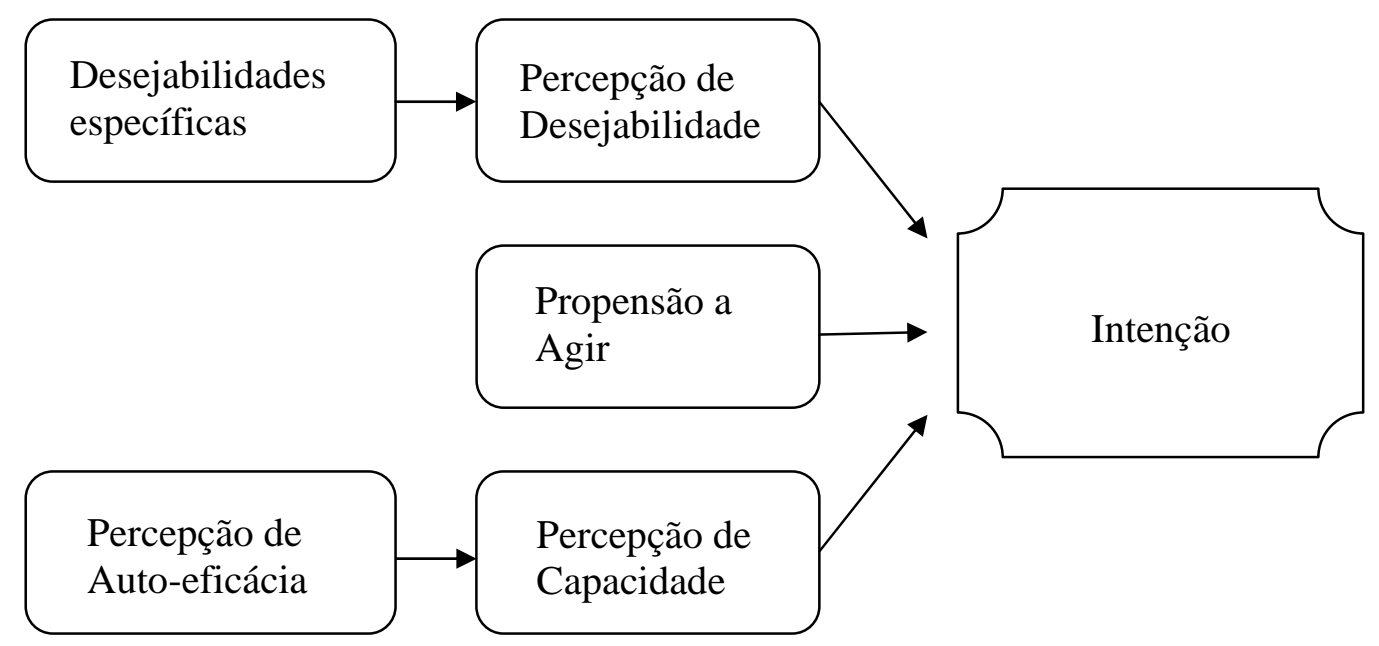

Figura 6 - Modelo Shapero-Krueger

Fonte: Krueger, Reilly e Carsrud (2000)

O modelo de Shapero é formado por três constructos e as influências exógenas influenciam dois destes constructos, relacionados com percepção, que determinam a intenção. O constructo percepção de desejabilidade refere-se ao interesse de iniciar um negócio, enquanto percepção de capacidade é o grau em que o agente acredita ser capaz de iniciar um negócio. O teste empírico 
sugerido por Shapero é a utilização de questões com oito itens, com o objetivo de investigar diferentes aspectos de percepção de desejabilidade e de capacidade. Com respeito ao constructo propensão a agir, refere-se à disposição do indivíduo para agir em uma decisão, isto é, a determinação de intentar. Shapero sugere que empiricamente medidas de lócus interno de controle sejam utilizadas; entretanto, gerentes e empresários têm medidas similares (KRUEGER, REILLY e CARSRUD, 2000).

O confronto das propostas de Ajzen e Shapero indica que os modelos são similares. Os modelos preocupam-se com a questão de percepção dos agentes, sendo a principal diferença a incorporação por Shapero da propensão a agir. Segundo Krueger, Reilly e Carsrud (2000) isso representa um avanço, pois há referências na literatura de casos em que não havia a intenção de se tornar empresário, mas o agente se tornou empresário, ou seja, intenção difere de comportamento. Os estudos que utilizam tais referenciais como o de Krueger, Reilly e Carsrud (2000), que confrontam a aplicabilidade das duas teorias para explicar o comportamento empresarial dentre estudantes universitários que estão terminando seus cursos, teve como resultado que o modelo de Shapero ajusta-se melhor. No entanto, é ressaltada a necessidade de refinamentos para um melhor poder de explicação de ambos os modelos. Outro ponto que chama a atenção é o papel do desejo em influenciar a intenção. Este fator, o desejo por desempenhar uma ocupação profissional, tem um papel que pode ser considerado coadjuvante nos modelos apresentados. A importância da elaboração de modelos em que desejo e emoção têm papel também de protagonista é enfatizado por Bagozzi (2000), em sua análise aplicada ao questionamento do uso da teoria econômica tradicional para o contexto de escolha dos consumidores por bens e serviços. Segundo o autor, o desejo e a emoção são importantes antecedentes da decisão e do comportamento dos indivíduos; assim, justifica-se que os modelos de escolha dos consumidores considerem estes aspectos como de suma relevância.

\subsubsection{Modelo fundamentado na teoria sócio-cognitiva da carreira}

A última teoria que é apresentada neste item é a teoria sócio-cognitiva da carreira, proposta por Lent et al.. (1994). De acordo com Silva (2005), esta teoria tem uma história recente que remonta a trabalhos iniciados por Hackett e Betz na década de oitenta do século XX. A proposta formal data de 1994, com a publicação da monografia intitulada "Buscando a unificação da teoria 
cognitiva social da carreira e interesse, escolha e performance acadêmica” por Lent, Brown e Hackett. É apropriado enfatizar o conceito de cognição a fim de clarificar o entendimento desta corrente teórica. A palavra cognição tem origem do latim cognitione, que significa aquisição de conhecimento através da percepção. Na literatura encontram-se definições como ato ou processo de conhecer, que envolve atenção, percepção, memória, raciocínio, juízo, imaginação, pensamento ou linguagem. Ainda, a capacidade de processar informações, de reagir ao que percebemos no mundo e em nós mesmos (SANTOS, 2007).

A proposta de Lent et al.. (1994) é de elaborar uma teoria que integre a proposta da teoria cognitiva social geral e os modelos que existem de escolha de carreira. O objetivo do trabalho é entender três elos relacionados a aspectos do desenvolvimento de carreira de uma perspectiva de cognição social. Os elos são a formação de interesse por uma determinada carreira, a seleção de opções de escolha de área de estudo e de preferência ocupacional e o desempenho e a persistência no prosseguimento de uma área de estudo e carreira.

A teoria sócio-cognitiva da carreira reconhece que existe uma interação entre as pessoas, o ambiente e o comportamento; assim, fundamenta-se no modelo proposto por Bandura, denominado reciprocidade triádica. Desta forma, tem-se que os atributos pessoais, como estados cognitivos e afetivos internos e atributos físicos, os fatores ambientais externos e o comportamento explicito, isto é, distintos de qualidades internas e físicas são elementos que operam como mecanismos interligados, cuja direção de influência é bidirecional. Lent et al.. (1994) salientam que Osipow afirma que a maioria dos modelos de desenvolvimento de carreira descrevem que a escolha é determinada por pessoa e ambiente, porém, a relação entre as variáveis é parcialmente bidirecional. Ainda, os autores citam que Bandura enfatiza que o comportamento é resultado da interação entre pessoa e ambiente. Desta maneira, a crítica e o avanço da proposta de Lent et al.., fundamentada na teoria de Bandura, reside em que o comportamento não é um produto da interação entre pessoa e ambiente, além de que, se trata de relacionamentos bidirecionais, e não parcialmente bidirecionais.

A teoria cognitiva de Bandura reconhece vários tipos de mecanismos sócio-cognitivos que determinam o sistema tríadico, como por exemplo, processos cognitivos, vicariantes, autoregulatórios e auto-reflexivos. A proposta de Lent et al.. (1994) considera dentre os mecanismos sócio-cognitivos a auto-eficácia, a expectativa de resultados e os objetivos como componentes importantes da explicação da escolha por uma ocupação. 
A auto-eficácia é um aspecto que é realçado na maioria dos modelos de escolha ocupacional. Este componente é definido no modelo a partir da definição de Bandura e significa o reconhecimento dos indivíduos das suas capacidades para organizar e executar as medidas necessárias para atingir os tipos de desempenho designados. A auto-eficácia tem como característica ser um conjunto de crenças ativas e dinâmicas, que são específicas para se desempenhar um comportamento e interagem complexamente com outros indivíduos, comportamentos e fatores contextuais.

A expectativa de resultado é outro componente que compõe o modelo de sócio-cognição da carreira. A opinião pessoal sobre resultados prováveis de um comportamento é a definição para este componente. Lent et al.. (1994) citam que Bandura classifica em diversos tipos a expectativa de resultado, por exemplo, antecipação de condições físicas tangíveis (questão monetária, etc), social (aprovação), auto-avaliadoras (satisfação). E que a atuação dos indivíduos depende de dois aspectos, a auto-eficácia e expectativa de resultados; entretanto, o primeiro aspecto tem maior influência no comportamento. O último elemento da proposta de Lent et al.. (1994) são os objetivos, que são ubíquos e, geralmente implícitos nas decisões, porém, são mecanismos que motivam o processo e o desempenho da decisão. O comportamento não é uma resposta mecânica a forças determinísticas, pois os objetivos ajudam a orientar e a organizar o comportamento.

A proposta de Lent et al.. (1994) também incorpora no modelo a influência de fatores genéticos, habilidades e condições do ambiente na formação de interesse por uma carreira. Este modelo de Lent et al.. (1994) vai além do estudo da formação de interesse por uma carreira, a proposta visa entender também a intenção, o comportamento e o desempenho. A partir da formação do interesse têm-se os outros focos de entendimento da teoria que são a intenção, o comportamento e o desempenho. Interesse é definido como o gosto, a antipatia e a indiferença por uma ocupação e promove o envolvimento e a busca de aquisição de habilidades relacionadas ao campo de interesse. Sinteticamente, o modelo fundamentado na teoria sócio-cognitiva da carreira descreve que o interesse conduz à intenção; a conseqüência de ter intenção é o aumento da probabilidade de um comportamento. A decisão de ter um comportamento acarreta uma performance, que pode ser um sucesso ou uma falha, daí o agente pode persistir ou não na escolha. Na Figura 7 é apresentada esquematicamente a proposta de Lent et al.. (1994).

As proposições quanto aos relacionamentos do modelo da teoria sócio-cognitiva da carreira são em número de doze. Citar-se-ão algumas dessas: 
- O interesse de um indivíduo por um campo do conhecimento ou carreira em qualquer momento é reflexo de sua crença de auto-eficácia e de expectativa de resultados;

- Interesse ocupacional de um indivíduo é também influenciado por suas habilidades, mas mediadas pelas crenças de auto-eficácia;

- Crença da auto-eficácia afeta intenção e comportamento tanto direta quanto indiretamente;

- Expectativa de resultado afeta intenção e comportamento tanto direta quanto indiretamente;

- Indivíduos aspirarão a desenvolver uma ocupação que seja consistente com seus interesses principais;

- Interesse afeta comportamento tanto direta quanto indiretamente;

- Crenças de auto-eficácia são resultado de exposição a experiências, estímulos e visão da sociedade, etc. 


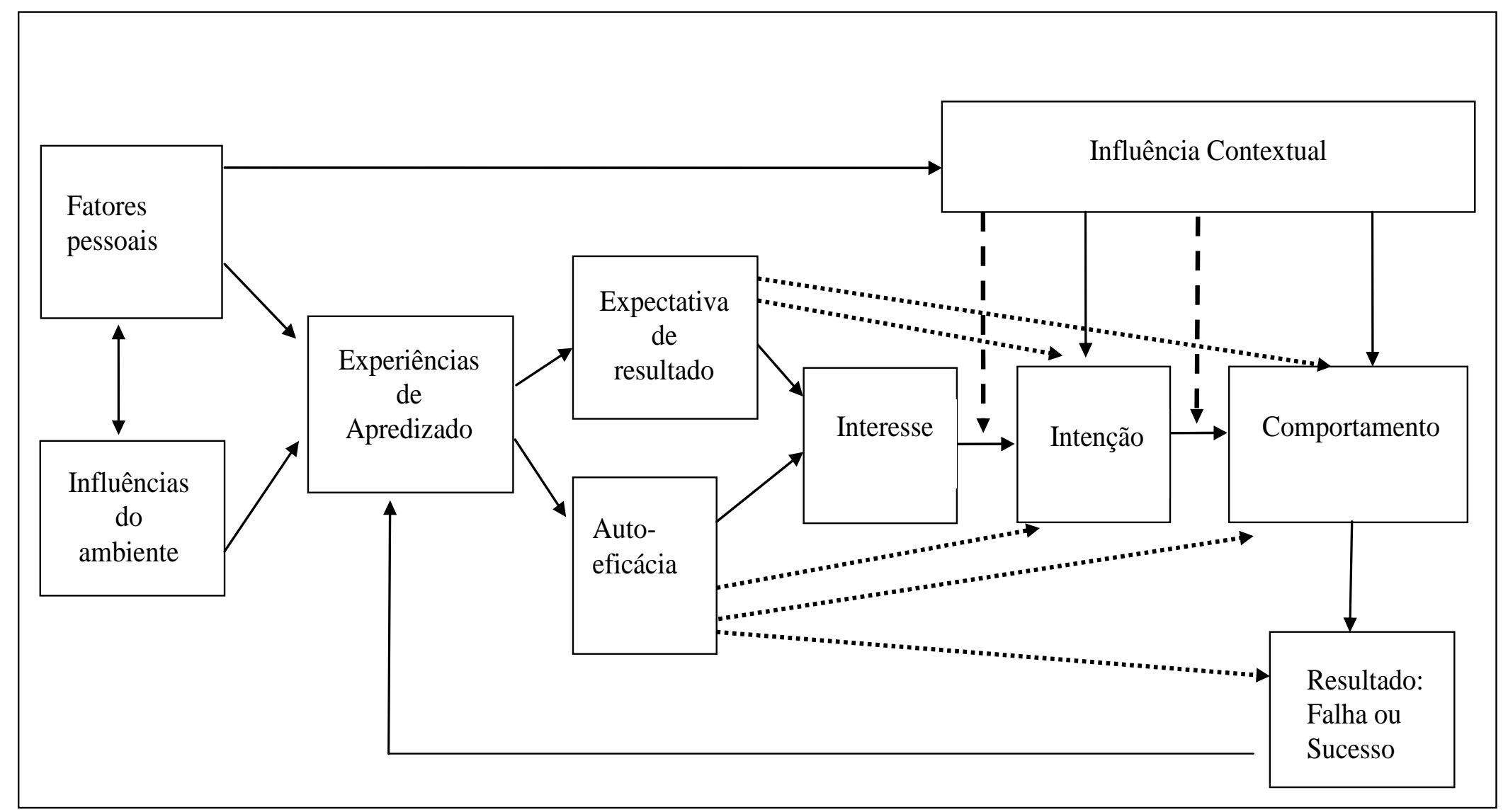

Figura 7 - Modelo dos fatores pessoais, contextuais e experimentais que afetam o comportamento de escolha por uma carreira Fonte: Lent et al.. (1994) 
A reciprocidade triádica proposta por Bandura define que há relação de causalidade bidirecional entre as variáveis. O modelo proposto por Lent et al.. (1994), apesar de considerar a reciprocidade triádica de Bandura, não considera a bidirecionalidade. No entanto, Lent et al.. (1994) ressaltam que reconhece que pessoa, comportamento e contexto influenciam uns aos outros e em qualquer momento algumas variáveis podem ter um peso de influência maior do que as demais. Como exemplo, os autores citam que condições sócio-econômicas como pobreza extrema podem afetar a escolha por uma carreira por ter impacto em componentes da proposta como oportunidade de aprendizado.

A maioria das abordagens tendem a ser reducionistas ao focarem uma disciplina do conhecimento humano. Isto compromete os resultados, quando aplicadas ao mundo real. Lent et al.. (1994) fazem o apontamento de que uma variedade de fatores importantes como condições econômicas e sociais afetam o poder explicativo do modelo. Ainda, os autores assinalam a necessidade de haver uma convergência entre as teorias, ao invés de uma proliferação delas.

A incorporação do fator interesse pode ser vista como um avanço desta proposta e revela que é apropriada para ser utilizada em análises econômicas. Conforme ressaltado pelos autores desta teoria, um dos calcanhares de Aquiles é a abstenção de questões econômicas. Por sua vez, um questionamento que vem ganhando espaço na economia é a questão da incorporação de emoção e desejo aos modelos econômicos. Bagozzi (2000), em seu trabalho de crítica à teoria do comportamento do consumidor, enfatiza que é necessário que a especificação científica de comportamento na teoria econômica seja revista. O autor apresenta uma sugestão de modelo que se fundamenta na filosofia da mente e na atitude, e nos modelos de psicologia social e marketing de comportamento intencional. Na

Figura 8, é apresentado um esquema sintético das variáveis- chave da proposta de Bagozzi (2000). 


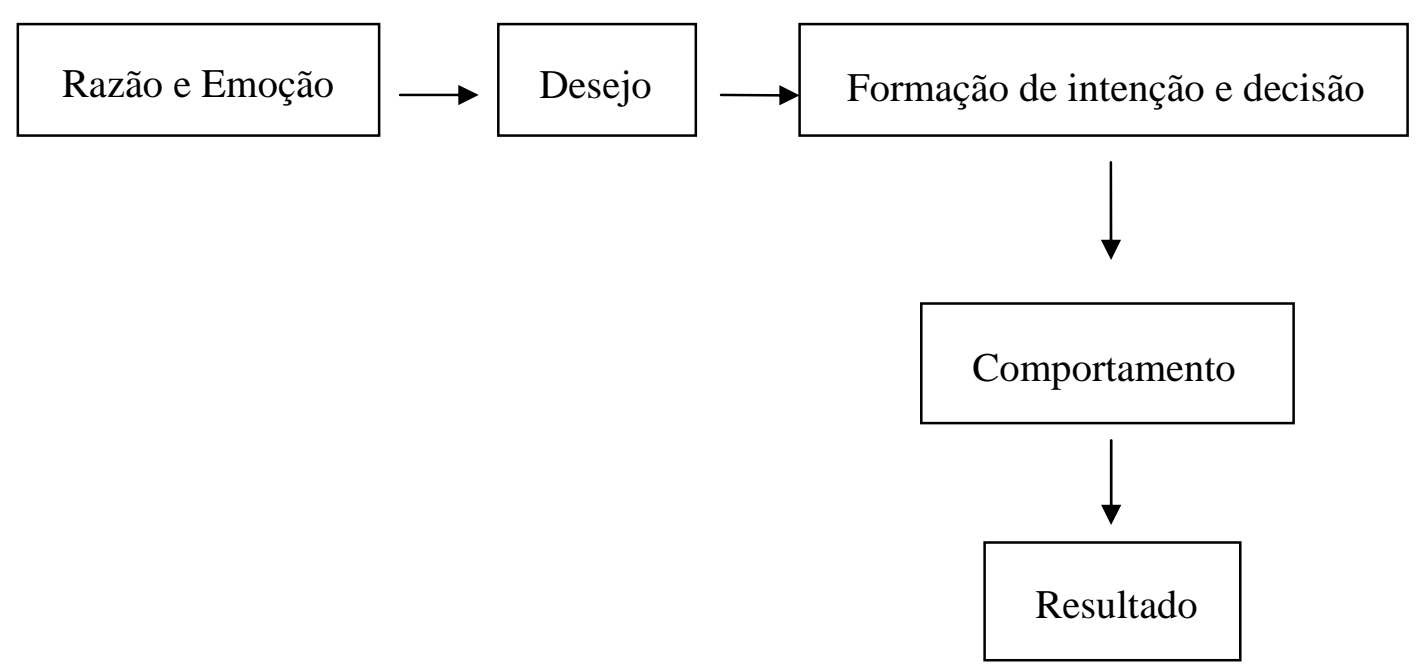

Figura 8 - Esquematização da proposta de Bagozzi (2000)

Fonte: Elaborado pela autora.

Bagozzi (2000) enfatiza que emoção é um ingrediente presente na tomada de decisão, entretanto, o relacionamento entre emoção e tomada de decisão é um aspecto negligenciado e evitado pelos economistas. O autor, em seu trabalho aplicado ao contexto do consumidor, sugere que a inclusão de razão e motivação para consumir implicaria em maior aderência dos modelos ao cotidiano. Considera-se como razões para consumir processos cognitivos que consistem em diversas avaliações racionais. No modelo proposto por Bagozzi (2000) este aspecto é representado por atitudes e normas subjetivas. Atitudes são reações pessoais a um produto ou serviço e normas subjetivas englobam aspectos interpessoais do consumo. O componente motivação para consumir é formado pelas emoções antecipadas, que são as avaliações das reações emocionais para se alcançar ou não um objetivo. Outro motivador para se tomar uma decisão é o desejo.

O desejo tem um papel central na escolha de objetivos, e produz a intenção de se ter um comportamento (BAGOZZI, 2000). O autor cita que alguns filósofos afirmam que o desejo tem um relacionamento particular com a intenção, motivando uma tomada de decisão ou então, formando uma intenção de agir. É sintetizado no trabalho que desejo funciona como uma representação mental de auto-satisfação que estimula a tomada de decisão.

Resumindo, o modelo de teoria sócio-cognitiva da carreira é uma proposta em desenvolvimento, cujos autores sugerem que necessita de questionamento minucioso. Essa 
proposta foi formulada para a escolha de uma carreira, não fazendo nenhuma menção à questão de empreendedorismo. No entanto, representa um avanço ao buscar incorporar ao modelo um antecedente plausível à intenção, diferenciando-se, assim, das propostas de Ajzen e de Shapero, cujo foco é a intenção. Em outra via, diversos economistas independentemente vêm apontando a necessidade tanto da revisão dos modelos comportamentais adotados na análise econômica quanto da incorporação de todos os aspectos relacionados à atividade empresarial na análise econômica. O que os economistas visam é a elaboração de modelos que melhor se ajustem à realidade, a fim de que as análises, predições e tentativas de estímulo ao crescimento sejam mais eficientes. Desta forma, a adaptação de modelos como o proposto pela teoria sócio-cognitiva da carreira a questionamentos de cunho empresarial pela ciência econômica não representa um erro. 


\section{METODOLOGIA}

Neste trabalho adotou-se classificação de quatro fatores de produção e quatro formas de remuneração deles. Entende-se como fatores de produção: capital natural, mão-de-obra, capitais físicos e financeiros e empresários, sendo, respectivamente, as formas de remunerações: aluguéis, salários, juros e lucros. Tal opção é defendida por se considerar que a distribuição funcional da renda gerada pela produção deve remunerar todos os fatores envolvidos. Então, é questionável que existam três fatores de produção e quatro formas de remuneração. Além disso, considera-se plausível a proposta de Say, citada por Audretsch, Heblich e Monsen (2007), que afirma existir um fator denominado indústria humana, que é composto por empresários, pesquisadores e trabalhadores.

Neste estudo buscou-se avaliar o fator de produção empresário, enfatizando o papel do ensino superior na formação do gosto e da intenção de atuar como empresário. Para tal escolheuse entrevistar os formandos e ingressantes de uma tradicional escola de ensino de agricultura em nível superior, a Escola Superior de Agricultura “Luiz de Queiroz”, que foi denominada de escola PUB - ESALQ. Com o papel de ser um grupo controle, também foram entrevistados os alunos de outra instituição de ensino superior, a ser denominada de escola PRI. Esta é um grupo controle na análise dos resultados, já que, nela, não há enfoque no ensino de questões agrícolas em seus cursos.

O conceito de empresário a ser utilizado no estudo abstrai da ótica de separar empresário de inovador, considerando-se que ser inovativo não é condição necessária para ser empresário. É oportuno salientar que a inovação é importante dado, pois em uma economia capitalista a sobrevivência dos empresários está associada com a necessidade contínua de diferenciação. No entanto, defende-se que a inovação está ligada ao resultado e não à formação da vontade e da intenção. O empresário é considerado como aquele que coordena os demais fatores de produção, a saber: terra, capitais físicos e financeiros e mão-de-obra. A forma como a coordenação se dá não diferencia se ela é inovativa ou imitativa.

O presente estudo fundamentou-se na abordagem que defende ser possível existirem empresários a partir de estímulos. Considerando-se as deficiências relacionadas com a abordagem psicológica das origens e com os fatores que afetam o capital empresarial, a coleta de dados não se limitou às questões relacionadas a traços de personalidade. Entretanto, considera-se que o 
gosto é um aspecto que explica a intenção de ser empresário. Desta forma, as propostas de Lent et al.. (1994) do modelo fundamentado na teoria sócio-cognitiva da carreira e as discussões de Bagozzi (2000) acerca da importância da consideração do desejo nos modelos econômicos guiam este estudo.

O esquema apresentado na Figura 9 é inspirado nos modelos de Lent et al.. (1994) e Bagozzi (2000). O modelo de Lent et al.. (1994) foi adaptado, incorporando a influência das forças situacionais no resultado e explicitado o papel do feedback das experiências. Esta mudança é feita com base na proposta de Bagozzi (2000). Acredita-se que tal adaptação resulta em uma melhor aplicação do modelo de Lent ao contexto empresarial. 


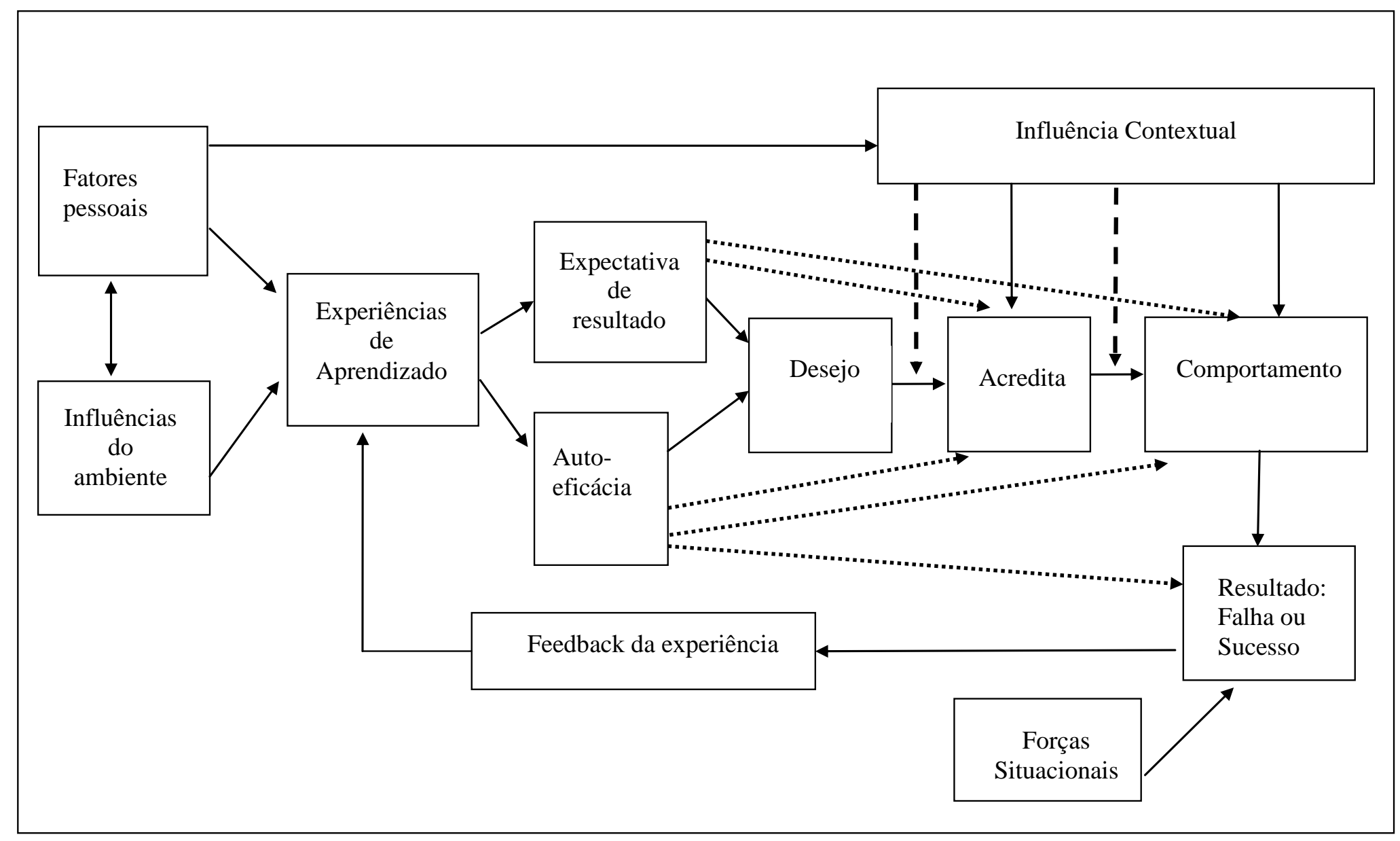

Figura 9 - Modelo explicativo do comportamento empresarial dos indivíduos

Fonte: Elaborado pela autora 
A Figura 9, conforme já salientado, é inspirada nos modelos de Lent et al.. (1994) e Bagozzi (2000). A abordagem de Lent et al.. (1994) difere dos modelos propostos por Ajzens e Shapero por enfatizarem a importância do desejo. Conforme já discutido, a proposta de Bagozzi (2000) é aplicada ao contexto de escolha dos consumidores, mas faz a ressalva de que os modelos econômicos estão incompletos. A tentativa de desprover da ciência econômica a questão de moral e ética falha, pois os seres humanos pensam e agem de acordo com seus valores. Assim, a economia positiva, representada pelos modelos neoclássicos, fornece explicações incompletas, e a proposta de Bagozzi visa iniciar uma discussão de aperfeiçoamento dos modelos. O desejo pode ser considerado como interesse; assim, casam-se as propostas de Lent et al.. (1994) e Bagozzi (2000). Neste trabalho ainda considera-se que o gosto é sinônimo dos dois termos, e assim o gosto é o ponto inicial para o entendimento de um comportamento, conforme se verifica na Figura 10.

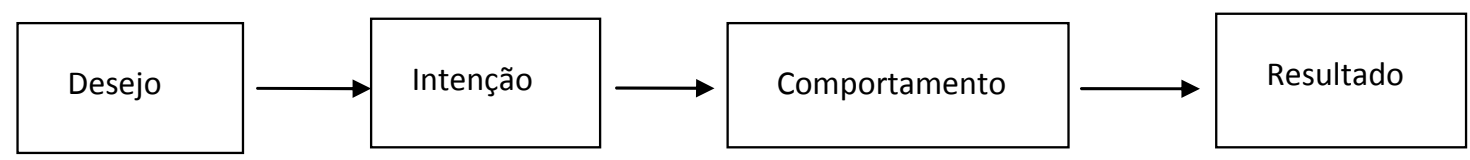

Figura 10 - Esquematização dos fatores que explicam a escolha por uma ocupação profissional Fonte: Elaborado pela autora

A proposta deste estudo visa entender os fatores que influenciam nestes relacionamentos e ainda analisar a questão de o gosto ser um bom preditor de intenção, mas nem sempre há total correlação entre as variáveis. Assim, existem aspectos que podem representar obstáculos ou ser empecilhos para que o gosto corresponda à intenção.

É oportuno salientar alguns aspectos metodológicos da pesquisa a fim de minimizar interpretações errôneas. Em primeiro lugar, por restrição de tempo, são avaliados os constructos da Figura 10 referentes ao desejo e à intenção. Neste estudo, desejo é sinônimo de gosto e intenção é sinônimo de acreditar. A pesquisa é realizada em duas dimensões, a dos ingressantes e a dos formandos. O papel da educação no gosto e na intenção, ou seja, a identificação do tipo de treinamento formal dado pelo ensino superior é avaliada entre estes grupos. Desta forma, se houver diferenças entre os ingressantes e formandos estas são atribuídas ao tipo de treinamento recebido no ensino de nível superior. O que valida esta suposição é a existência de processo 
seletivo para a admissão dos alunos. Assim, acredita-se que o material humano seja o mesmo e que as diferenças, se existirem entre as expectativas, seriam originárias do foco do treinamento.

No desenho do questionário acreditou-se que os relacionamentos constantes na Figura 11 seriam pertinentes. As análises a ser realizadas verificam se os relacionamentos apresentados na Figura 11 se realizam; em caso positivo, como influenciam e se há diferença entre os tipos ocupacionais. Como tipos ocupacionais foram considerados funcionários da iniciativa privada, funcionários da esfera pública e empresários. O desencontro com a proposta apresentada na Figura 9 se deu em razão do conhecimento posterior da proposta de Lent et al..(1994). Assim, se buscará adaptar, na medida do possível, o questionário para a verificação da validade da proposta de Lent et al..(1994), verificando os relacionamentos e o comportamento das variáveis do questionário. 


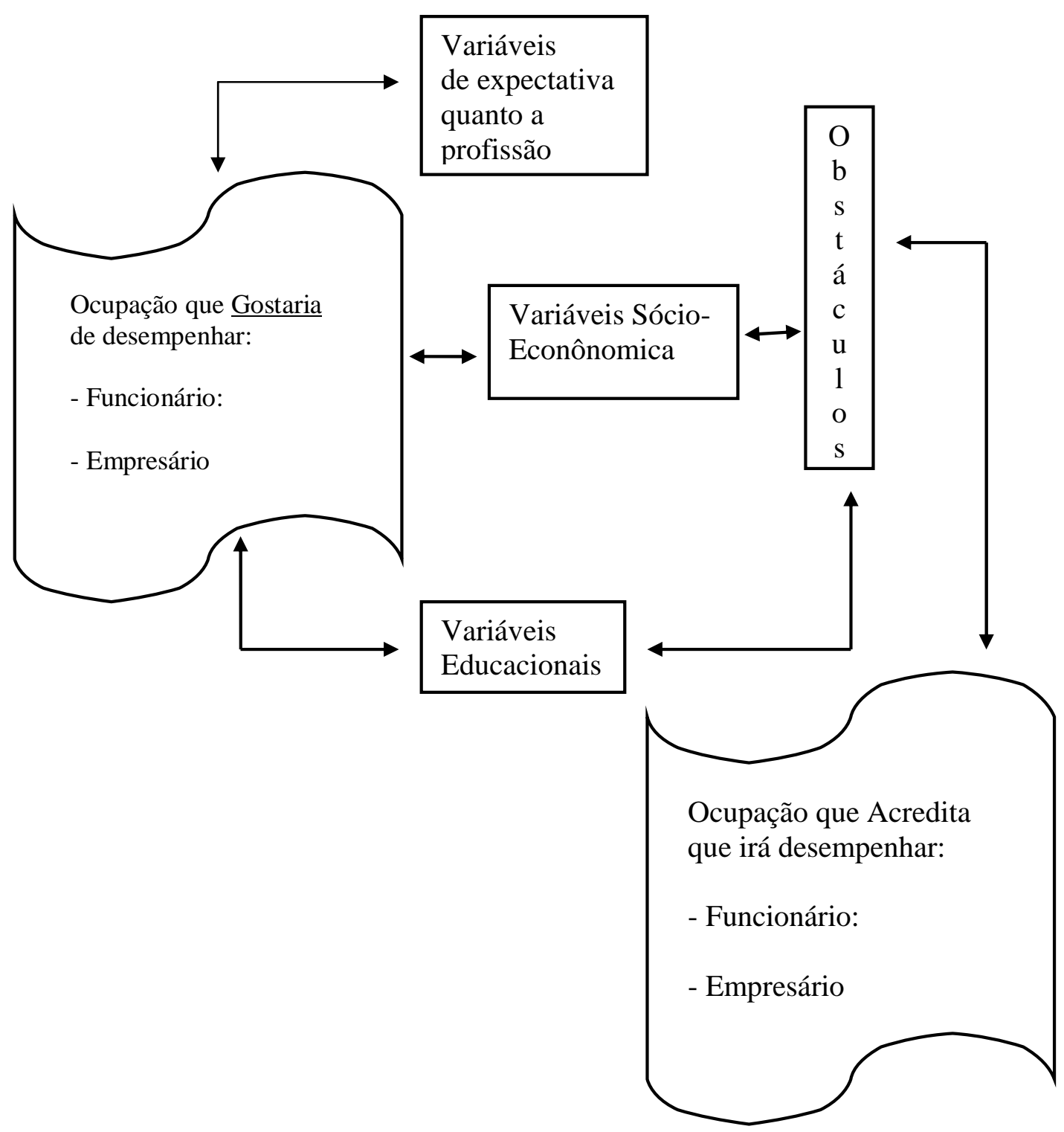

Figura 11 - Esquema da pesquisa

Fonte: Elaborado pela autora

Na Figura 11 verifica-se que o gosto por uma ocupação profissional é fruto da influência de variáveis que refletem o seu perfil sócio-econômico, de expectativas quanto ao exercício da profissão e de variáveis relacionadas à questão educacional. Observa-se que a relação de causalidade é bidirecional. A possível diferença entre gosto e crença é atribuída à existência de obstáculos como questões político-econômicas e questões relativas a recursos financeiros. Cabe 
salientar que os obstáculos são também resultados de questões pessoais dos indivíduos, como orientação familiar, e aspectos educacionais, como, por exemplo, treinamento formal deficiente.

\subsection{Fonte dos dados}

A origem dos dados da pesquisa foi de fonte primária, sendo que o nome de uma das instituições não foi divulgado. Desta forma, foram aplicados questionários em formandos e em ingressantes, a fim de se verificar os determinantes da formação de gosto, se o gosto corresponde à intenção, o efeito da educação na decisão de escolha ocupacional, as expectativas dos formandos com relação à ocupação que desempenharão e se o treinamento dado pelo ensino superior é um facilitador no desenvolvimento de competências empresariais.

\subsubsection{A instituição PUB - ESALQ}

Uma das instituições em que foi feito o estudo de caso é a Escola Superior de Agricultura “Luiz de Queiroz” - ESALQ, aqui denominada de PUB - ESALQ. Esta instituição é tradicional no ensino de ciências agrárias no país, e segundo Ferraro (2005), é uma das importantes instituições que auxiliaram na modernização da agricultura. Este autor afirma que a modernização da agricultura no início do século XX necessitava de aspectos tais como desenvolver processos científicos, novas tecnologias, difusão destes novos procedimentos através da mídia de então e formação de pessoal qualificado para suprir a demanda existente em quase todos os setores ligados à agricultura. Ferraro (2005) cita que Murari (2002) enfatiza que era necessário, naquela época, o desenvolvimento de um novo tipo de fazendeiro que fosse um profissional de ação, inteligente, enérgico, empreendedor e ativo, que olhasse para a crise não como uma situação desastrosa, já que dispunha de conhecimento técnico para enfrentá-la.

A ESALQ foi inaugurada em 3 de Junho de 1901, data da primeira matrícula. No primeiro ano de atividades tinha 11 alunos e 3 ouvintes, e em agosto de 2007 havia em nível de graduação 1.932 alunos matriculados e 11.178 alunos formados, sendo que são admitidos 390 alunos anualmente através de exame vestibular. Os cursos que a escola tem atualmente, em nível de graduação, são: Ciências Biológicas, Ciências dos Alimentos, Ciências Econômicas, Engenharia Agronômica, Engenharia Florestal e Gestão Ambiental. Cabe salientar que na escola é 
disponibilizada uma disciplina denominada de Formação Empreendedorial: Inovação e Criação de Novos Negócios.

\subsubsection{A instituição PRI}

O estudo de caso foi realizado também em uma escola privada denominada neste estudo de PRI. Esta escola foi iniciada nos anos 60, sendo os primeiros cursos: Economia, Administração e Ciências Contábeis e, posteriormente, se tornou universidade. A escola PRI oferece cerca de 30 cursos em nível superior. Os questionários foram aplicados nos cursos de Administração de Empresa tanto diurno quanto noturno e no curso de Ciências Econômicas. Nesta instituição, são oferecidos para os cursos de Administração as disciplinas Gestão Empreendedora e Criação de Negócios.

\subsection{Questionário}

O questionário elaborado visou identificar e permitir a análise do capital empresarial no agronegócio com destaque no papel da educação superior no desenvolvimento de competências empresariais. Para tanto, o questionário foi aplicado nas duas escolas apresentadas na fonte de dados, a escola PUB - ESALQ e a escola PRI.

O processo de elaboração do questionário envolveu a aplicação de testes com protótipos a fim de identificar problemas quanto à interpretação das questões. Foi simulada a aplicação do questionário no campus da escola PUB - ESALQ com alunos que não eram formandos. Após cada teste, foram realizadas mudanças com o intuito de facilitar o entendimento e a visualização das questões.

A pesquisa foi intitulada de "Pesquisa sobre a expectativa de empregabilidade dos alunos da PUB - ESALQ” e "Pesquisa sobre a expectativa de empregabilidade dos alunos da PRI”. Tal denominação para a pesquisa que trata de capital empresarial foi adotada com o objetivo de reduzir vieses de respostas. Acreditou-se que a utilização do termo empreendedorismo poderia levar a uma tendenciosidade na resposta dos alunos. Desta forma, foi substituído por empregabilidade.

A coleta de dados por meio de questionário é um instrumento muito utilizado em pesquisas sociais, principalmente os que visam analisar comportamentos. Entretanto, conforme afirma 
Chagas (2000), não há uma metodologia para nortear a elaboração deles. O que existe são recomendações a fim de minimizar os problemas na mensuração. Como possíveis problemas da utilização deste instrumento de coleta de dados, o autor cita, por exemplo, a existência de diferenças em razão de fatores pessoais passageiros, a fatores de situação, a variação no método de aplicar o questionário, a amostragem dos itens, a falta de clareza dos instrumentos de pesquisa, a questionários mal elaborados, entre outros.

\subsection{Estrutura do questionário}

O questionário foi composto de três blocos de questões que buscavam, de modo geral, testar se os aspectos discutidos na literatura como relevantes na escolha ocupacional são aplicados ao estudo de caso desta pesquisa. Também buscou-se avaliar os fatores dos perfis ocupacionais.

O questionário foi composto de 17 questões quantitativas e qualitativas, sendo que as últimas correspondem à maior parte do questionário. As qualitativas são nominais e ordinais. No caso das ordinais, a maior parte destas foi mensurada em uma escala de 0 a 10. Esta opção de escala foi adotada por facilitar a resposta por parte dos formandos, dado o costume deles com esta forma de escala, por exemplo, seu desempenho acadêmico é avaliado por este tipo de escala. Os questionários são apresentados no Anexo. Na Tabela 1 é apresentada a estrutura do questionário aplicado. 
Tabela 1 - Listagem das questões a serem pesquisadas

\begin{tabular}{|c|c|c|c|c|}
\hline Bloco & Objetivo & Questão & Natureza & $\begin{array}{c}\text { Valores/Níveis ou } \\
\text { categorias }\end{array}$ \\
\hline \multirow{12}{*}{$\begin{array}{l}\text { Perfil Sócio- } \\
\text { econômico }\end{array}$} & \multirow{12}{*}{$\begin{array}{l}\text { Caracterização } \\
\text { Sócio-Econômica } \\
\text { da população }\end{array}$} & 1 & $\begin{array}{l}\text { Qualitativa } \\
\text { nominal }\end{array}$ & $\begin{array}{c}\text { Masculino } \\
\text { Feminino }\end{array}$ \\
\hline & & 2 & Descritiva & $1^{*}$ \\
\hline & & 3 & $\begin{array}{l}\text { Quantitativa } \\
\text { contínua }\end{array}$ & $1^{*}$ \\
\hline & & 4 & $\begin{array}{l}\text { Qualitativa } \\
\text { nominal }\end{array}$ & Cursos avaliados \\
\hline & & 5 & $\begin{array}{l}\text { Quantitativa } \\
\text { contínua }\end{array}$ & $1^{*}$ \\
\hline & & 6 & $\begin{array}{c}\text { Qualitativa } \\
\text { nominal }\end{array}$ & $1^{*}$ \\
\hline & & 7 & $\begin{array}{c}\text { Qualitativa } \\
\text { ordinal }\end{array}$ & $\begin{array}{l}\text { Nunca, raramente, de } \\
\text { vez em quando, } \\
\text { freqüientemente, } \\
\text { diariamente }\end{array}$ \\
\hline & & 8 & $\begin{array}{l}\text { Qualitativa } \\
\text { nominal }\end{array}$ & $1^{*}$ \\
\hline & & 9 & Descritiva & $1^{*}$ \\
\hline & & 10 & $\begin{array}{l}\text { Qualitativa } \\
\text { nominal }\end{array}$ & $1^{*}$ \\
\hline & & 16 & $\begin{array}{l}\text { Quantitativa } \\
\text { contínua }\end{array}$ & $1^{*}$ \\
\hline & & 17 & $\begin{array}{l}\text { Qualitativa } \\
\text { ordinal }\end{array}$ & $\begin{array}{l}\text { De } 1 \text { a } 4 \text { Sm, de } 5 \text { a } \\
\text { 10, de } 11 \text { a } 15 \text {, de } 16 \text { a } \\
\text { 20, mais de } 20 \mathrm{Sm}\end{array}$ \\
\hline \multirow[t]{2}{*}{$\begin{array}{l}\text { Preferência } \\
\text { profissional }\end{array}$} & \multirow{2}{*}{$\begin{array}{c}\text { Caracterização da } \\
\text { preferência } \\
\text { profissional }\end{array}$} & 11 & $\begin{array}{l}\text { Qualitativa } \\
\text { ordinal }\end{array}$ & De 0 a 8 \\
\hline & & 12 & $\begin{array}{l}\text { Qualitativa } \\
\text { ordinal }\end{array}$ & De 0 a 10 \\
\hline \multirow[t]{3}{*}{ Influência } & \multirow{3}{*}{$\begin{array}{l}\text { Averiguar fatores } \\
\text { que interferem no } \\
\text { gosto pelo tipo de } \\
\text { ocupação }\end{array}$} & 13 & $\begin{array}{l}\text { Qualitativa } \\
\text { ordinal }\end{array}$ & De 0 a 10 \\
\hline & & 14 & $\begin{array}{l}\text { Qualitativa } \\
\text { ordinal }\end{array}$ & De 0 a 10 \\
\hline & & 15 & $\begin{array}{l}\text { Qualitativa } \\
\text { ordinal }\end{array}$ & De 0 a 10 \\
\hline
\end{tabular}

Fonte: Elaborado pela autora.

* Vide questionário no anexo. 
A caracterização do perfil sócio-econômico dos alunos foi realizada na primeira parte, sendo duas questões posicionadas no final do questionário. A decisão de posicionar no final do questionário as questões que visam avaliar o comportamento de risco e a renda familiar foi baseada nas recomendações sobre elaboração de questionários. Ou seja, questões de cunho mais pessoal, sensível ou embaraçoso devem ser feitas no final do questionário, bem como as que classificam social, econômica ou demograficamente os respondentes (CHAGAS, 2000).

O bloco seguinte pode ser considerado como identificação do perfil ocupacional e das dificuldades que podem fazer com que aspirações não se realizem. Na questão 11 era necessário que os estudantes ingressantes e formandos classificassem, por ordem de preferência, as ocupações que acreditam estariam ocupando e que gostariam de ocupar em 7 e 12 anos, respectivamente. A questão seguinte visava identificar os obstáculos que faziam com que as aspirações não correspondessem à crença. É oportuno salientar que a questão 11 é a questão chave da pesquisa, a partir da qual se determinou que os questionários seriam válidos. O critério de exclusão do questionário implica em ordenar os itens desta questão repetindo os números da ordem de preferência. Portanto, os questionários considerados válidos são aqueles em que o aluno não classifica as opções com o mesmo peso de preferência, demonstrando, assim, uma ordenação lógica.

Por último, têm-se a seção que pode ser denominada como influenciadores na decisão. A escolha dos aspectos considerados nesta seção foi fundamentada em discussões realizadas na revisão bibliográfica. Como influenciadores da decisão consideram-se variáveis que, possivelmente, interferem na escolha, por exemplo, as pessoas do círculo social dos alunos, as características da profissão e os aspectos da educação em nível superior. Cabe salientar as diferenças entre os questionários, no caso da escola PUB - ESALQ e PRI. No questionário aplicado aos alunos da PRI foi excluído na questão 11 o item "trabalhando com assistência técnica e extensão rural”. A exclusão deste item se deu em razão de os cursos avaliados na PRI não terem ênfase em agricultura. Já com relação ao questionário aplicado aos ingressantes e formandos foram excluídos dos questionários aplicados aos ingressantes os itens "ter participado da empresa júnior” da questão 13 e disciplinas da questão 15. Ainda foi substituído o termo “professores do curso superior” por professores. 


\subsection{Aplicação do questionário}

Os questionários foram aplicados em duas fases. A primeira fase de aplicação foi realizada no período de novembro de 2006 a janeiro de 2007. A população a ser entrevistada foram os formandos da PUB - ESALQ e da PRI. A PUB - ESALQ é uma tradicional escola brasileira de formação agrícola em nível superior que atualmente têm seis cursos: Ciências Biológicas, Ciências dos Alimentos, Ciências Econômicas, Engenharia Agronômica, Engenharia Florestal e Gestão Ambiental. A aplicação dos questionários na PUB - ESALQ tem como público alvo os formandos e os ingressantes de todos os cursos. A PRI fez parte da população com o papel de ser um grupo controle para a comparação dos resultados encontrados com relação a PUB - ESALQ. A instituição pode ser considerada como um grupo controle por não se tratar de uma escola que visa à formação de pessoas que atuarão com o setor primário da economia. Os formandos da PRI que fazem parte da população da pesquisa são todos os estudantes dos cursos de Administração e de Ciências Econômicas. Na segunda fase, aplicaram-se os questionários aos alunos ingressantes no mês de fevereiro de 2007, na escola PUB - ESALQ, e fevereiro e início de março de 2007, na escola PRI. Os questionários foram aplicados na escola PUB - ESALQ nas aulas inaugurais dos cursos, de modo que os alunos não tivessem nenhum contato com o cotidiano dos cursos. Na escola PRI, o mesmo cuidado foi tomado, nas primeiras aulas foram aplicados os questionários.

O número de questionários a ser aplicado não foi determinado por técnicas de amostragem, dado o objetivo de se entrevistar toda a população de formandos das duas instituições escolhidas. A forma de aplicação do questionário foi por meio de abordagem pessoal aos formandos e também via e-mail; já com relação aos ingressantes, os questionários foram passados em sala de aula.

\subsection{Formas de análise das informações}

Os dados dos questionários foram analisados considerando-se alguns enfoques como, diferenciar o tipo das escolas em público e privado e diferenciar o perfil ocupacional. Os bancos de dados foram tabulados no Excel, pois permitia a exportação para qualquer software específico, e as análises estatísticas foram executadas no software SPSS 14.0. 
A comparação entre os dados foi possível, pois o questionário a ser aplicado foi o mesmo para todos os casos, com exceção dos aspectos já assinalados, como no questionário aplicado aos alunos da PRI, do qual foi excluído da questão 11 o item "trabalhando com assistência técnica e extensão rural”.

\subsection{Caracterização da amostra e Análise estatística dos dados}

Na primeira parte dos resultados é apresentada a caracterização da população em que foi aplicado o questionário.

A análise estatística dos dados foi realizada por meio de tabelas cruzadas, verificação de teste de normalidade, existência de outlier e teste não-paramétricos. A escolha da forma mais apropriada se deu através do tipo de dado a ser analisado. As tabelas cruzadas são indicadas para se analisar o relacionamento de duas ou mais variáveis qualitativas, independentes de serem nominais ou ordinais. É indicado que para variáveis quantitativas deve-se verificar se a variável ajusta-se a uma distribuição normal, e em caso positivo, média e demais medidas estatísticas podem ser analisadas. Já para comparação entre variáveis ordinais o emprego de técnicas não paramétricas é, geralmente, apropriado.

Siegel (1956) afirma que a análise da associação entre variáveis mensuradas por escores difere da aplicação de teste de simples existência de uma associação em determinada população. O autor discute que há dois interesses envolvidos nas análises deste tipo de dado. Primeiro, o interesse de se verificar o grau de associação entre variáveis deste tipo referentes a um grupo de indivíduos. E ainda, o interesse de se afirmar que, se observada alguma associação, esta indica, ou não, probabilidade de associação entre as variáveis na população da qual se extraiu a amostra.

Com o intuito de verificar a existência de diferenças entre as freqüências das respostas dos alunos ingressantes e formandos procedeu-se o teste de Chi-quadrado. A existência de diferenças estatisticamente significativas entre as freqüências das respostas dos estudantes ingressantes e formandos são consideradas como efeitos da educação no estímulo de formação de gosto e crença pelo desempenho das ocupações profissionais consideradas. O teste de qui-quadrado é um teste não-paramétrico que visa testar a hipótese de linha e coluna da tabela cruzada serem independentes. A independência entre linha e colunas significa que não existe diferença estatisticamente significativa entre as freqüências das respostas dos inqueridos. As suposições 
para a aplicação do teste são: os grupos devem ser independentes, os itens de cada grupo são selecionados aleatoriamente, as observações devem ser freqüências ou contagens, cada observação pertence a uma e somente uma categoria. Uma restrição ao uso do teste é que para tabelas de contigências, isto é, tabelas de freqüências cruzadas, de duas variáveis por duas variáveis, é necessário que a freqüência esperada mínima seja igual ou superior a cinco. Nas tabelas de contigência que apresentam dimensões maiores que $2 \times 2$, tem-se que o teste de quiquadrado não pode ser utilizado se mais de $20 \%$ das freqüências esperadas forem inferiores a cinco ou qualquer das freqüências for menor que a unidade (CAMPOS, 1976).

A aplicação do teste de Chi-quadrado, considerando o objetivo desta pesquisa, visa determinar se não há diferença estatisticamente significante entre os alunos ingressantes e formandos da formação do desejo e da intenção. A inexistência de diferença implica que as escolas não estão estimulando a formação de desejo e intenção nos alunos de atuar nas atividades profissionais consideradas. As hipóteses a serem testadas serão:

Ho: não existe diferença entre as freqüências

H1: existe diferença entre as freqüências

Se a hipótese Ho for verdadeira, espera-se que os valores esperados representem a estrutura global da amostra. O cálculo dos valores esperados para cada célula da tabela cruzada é apresentado na eq. (1):

$$
\begin{aligned}
& \text { esperado }=\frac{\text { total_linha } * \text { total_coluna }}{\text { total_geral }}=\text { total_linha } * \frac{\text { total_coluna }}{\text { total_geral }}= \\
& =\text { total_coluna } * \frac{\text { total_linha }}{\text { total_geral }}
\end{aligned}
$$

O cálculo do valor esperado permite testar se há independência entre as variáveis. Para isso, subtrai-se do valor esperado o valor observado a fim de se verificar a distância entre estes. Espera-se que as distâncias sejam as menores possíveis, a fim de existir a independência entre as variáveis. A verificação se as distâncias são grandes ou pequenas é calculada pela eq. (2) que dá o valor do chi-quadrado da amostra.

$$
\chi_{\text {amostra }}^{2}=\sum \frac{(\text { observado }- \text { esperado })^{2}}{\text { esperado }}
$$


Procedendo-se assim, tem-se o valor chi-quadrado da amostra, que seguirá uma distribuição de chi-quadrado com graus de liberdade iguais ao produto do número de linhas menos uma unidade vezes o número de colunas menos uma unidade, conforme pode ser observado abaixo:

$$
\chi_{\text {amostra }}^{2} \sim \chi_{v}^{2}
$$

Em que: $v$ representa o grau de liberdade e é igual a $: \mathrm{v}=\left(\mathrm{n}^{\mathrm{o}} \text { colunas }-1\right)^{*}\left(\mathrm{n}^{\mathrm{o}}\right.$ linha-1)

A verificação da validade da H0 é feita pela aceitação ou rejeição da mesma comparando-se o valor tabelado com o valor calculado pela eq. (2). No caso do estudo, como se empregou o software SPSS 14.0, obteve-se o p-valor, que é um valor mais exato do nível de significância.

A fim de verificar o ajustamento à distribuição normal de variáveis, foi aplicado o teste de Kolmogovov-Smirnov. Este teste avalia se a variável segue uma distribuição normal ou não. Cabe salientar que um valor de p-valor próximo de 0 , no caso deste teste, é indicativo de que os dados não se ajustam à distribuição normal. Em caso de não poder se considerar que os dados sigam distribuição normal, demais testes indicados foram aplicados, como exemplo, a investigação da presença de outliers.

O bloco em que se investigam os fatores influenciadores da decisão ocupacional permite que se verifique o comportamento das médias atribuídas aos itens. Para tal proposta procedeu-se a verificação do possível ajustamento à distribuição normal, e em caso negativo, conforme esperado, serão utilizados testes não paraméticos. Os testes que podem ser aplicados são o teste de Friedman, o teste de Wilconxon e o teste de Krustal-Wallis.

O primeiro teste a ser aplicado é o teste de Friedman, cujo objetivo é testar uma hipótese nula que os tratamentos são iguais entre si, contra a hipótese alternativa de que pelo menos dois tratamentos diferem entre si. De acordo com Pestana e Gangeiro (2000), este teste é adequado quando há três ou mais condições de emparelhamento, sendo a variável classificada em escala. Ainda de acordo com os autores, as respostas dos indivíduos para todas as vaiáveis são comparadas para se identificar diferenças entre os indivíduos com relação a preferências. As hipótese são uma hipótese nula, que considera que os tratamentos são iguais (Ho $=\mathrm{t} 1=\mathrm{t} 2=\ldots=$ tk), e outra alternativa, Ha: pelo menos dois tratamentos diferem entre si.

Sintetizando, o teste de Friedman testa a hipótese de que as médias entre os itens de cada questão não são estatisticamente diferentes entre si, contra a hipótese alternativa de que as respostas diferem no caso de pelo menos duas opções, dentro de cada resposta. Na literatura é assinalado que o teste de Friedman equivale a um teste $\mathrm{F}$ aplicado aos valores atribuídos pelas $\mathrm{k}$ 
amostras (observações) dentro de cada bloco. A utilização do teste de Friedman permite inferir se as k amostras são provenientes de uma mesma população ou de populações análogas, ou então, se provêm de populações distintas.

Campos (1976) apresenta a estatística do teste de Friedman, que é aproximada à distribuição do Qui-Quadrado, representada na eq. (4):

$$
X_{r}^{2}=\frac{12}{n k(k+1)} \sum_{i=1}^{k} R_{i}^{2}-3 n(k+1),
$$

Em que Ri é a soma das ordens atribuídas aos dados do tratamento i, nos n blocos.

Considerando-se um ajuste para o caso de empates entre os tratamentos, é indicado por Campos (1976) o cálculo da estatística, conforme a eq. (5):

$$
\begin{aligned}
& \chi^{2}=\frac{\frac{12}{n k(k+1)} \sum_{i} R_{i}^{2}-3 n(k+1)}{1-\frac{\sum_{j} T_{j}}{n k\left(k^{2}-1\right)}} \\
& \text { com } \\
& T_{j}=\sum_{i} t_{i j}^{3}-k
\end{aligned}
$$

Em que $t_{i j}=$ número de observações empatadas no grupo $i$ do bloco $j$.

Um resultado significativo do teste de Friedman viabiliza a identificação de quais fatores diferem quanto ao grau de influência na opção ocupacional. Para tal, optou-se pelo teste de Wilcoxon que possibilita inferir se a média de interferência atribuída, por exemplo, ao item pai difere estatisticamente da média dada a outro item. Este teste tem como hipóteses: $H_{0}: E(X)=$ $E(Y)$ e $H_{a}: E(X) \neq E(Y)$. O valor do teste é calculado com base na diferença $D_{i}=Y_{i}-X_{i}$ e a estatística do teste, havendo empates nos resultados é dada por:

$$
T=\frac{W^{+}-W^{-}}{\sqrt{\sum_{i=1}^{n} R_{i}^{2}}}
$$


Em que: $W^{+}$é a soma das ordens que correspondem às diferenças $D_{i}$ positivas; $W$ é a soma das ordens que correspondem a diferenças negativas; $R_{\mathrm{i}}$ é a ordem atribuída a $\left|D_{i}\right|$.

A existência de empate implica em outra estatística do teste, que é dada por:

$$
T=\frac{W^{+}-\frac{n(n+1)}{4}}{\sqrt{n(n+1)(2 n+1) / 24}}
$$

É oportuno salientar que havendo empates ou para grandes amostras a distribuição de T tende à distribuição normal.

A estatística de Kruskal-Wallis é outro teste não paramétrico utilizado com o intuito de testar a hipótese de igualdade com respeito à localização. Outra interpretação é que o teste averigua se k amostras independentes são provenientes de uma mesma população, ou provêm de populações distintas (Campos, 1976). Por exemplo, o perfil empresário interfere de forma diferente dos demais perfis. As hipóteses deste teste são: Ho: as k distribuições têm o mesmo parâmetro de localização; Ha: pelo menos uma das k populações têm um parâmetro de localização superior ou inferior ao das outras.

Campos (1976) discute que se o teste for aplicado a apenas 3 grupos com dimensão menor ou igual a 5, os respectivos valores podem ser obtidos junto a tabelas específicas. No caso de haver mais de três amostras independentes faz-se uma aproximação à distribuição do QuiQuadrado com (k-1) graus de liberdade. O teste é definido por:

$$
\begin{gathered}
H=\frac{12}{n(n+1)} \times \sum_{j}^{k} \frac{R_{j}^{2}}{n_{j}}-3(n+1), \text { caso não existam empates } \\
H_{E}=\frac{H}{1-\frac{\sum_{i}^{k}\left(t_{i}^{3}-t_{i}\right)}{n^{3}-n}} \text {, caso ocorram empates entre os resultados }
\end{gathered}
$$

Em que: $n$ = dimensão da amostra; $k$ = número de grupos; $R_{j}=$ ordenações da categoria j; $t_{i}$ = número de observações empatadas de cada categoria $\mathrm{i}$. 


\subsection{Análise fatorial}

A análise fatorial é uma técnica que permite que se reduza o número original de variáveis e se detectem estruturas nos dados. Considerando as questões que compõem o questionário aplicado aos estudantes, a análise fatorial foi utilizada a fim de reduzir a dimensão das informações, de tal maneira que os fatores extraídos possam explicar as variáveis originais. O histórico deste método inicia-se com os trabalhos de Karl Pearson em 1901 e Charles Spearman em 1904 para a elaboração de um índice de inteligência. Em 1947, Thurstone retomou a idéia dos precursores e desenvolveu a análise fatorial. Desde então, diversas áreas do conhecimento utilizam do método de análise fatorial (REIS, 1997).

Johnson e Wichern (2002) assinalam que o modelo fatorial para a i-ésima variável pode ser expresso algebricamente da seguinte forma:

$$
Y_{i}-\mu_{i}=l_{i 1} F_{1}+l_{i 2} F_{2}+\ldots+l_{i m} F_{i m}+\varepsilon_{i}
$$

Em que: $\mu_{i}$ é a média da variável i; $F_{j}$ representa o j-ésimo fator comum nãocorrelacionado, com média zero e variância unitária; $l_{i j}$ é o fator de carga da i-ésima variável no j-ésimo fator e $\varepsilon_{i}$ é o termo de erro, com média zero, que capta a variação específica em $Y_{i}$ não explicada pelos fatores comuns.

O modelo fatorial implica a seguinte estrutura de covariâncias para a i-ésima variável:

$$
\begin{gathered}
\operatorname{Var}\left(Y_{i}\right)=l_{i 1}^{2}+l_{i 2}^{2}+\ldots+l_{i m}^{2}+\Psi_{i} \\
\operatorname{Cov}\left(Y_{i}, Y_{k}\right)=l_{i 1} l_{k 1}+\ldots+l_{i m} l_{k m} \\
\operatorname{Cov}\left(Y_{i}, F_{j}\right)=l_{i j} \quad i=1,2, \ldots, p \quad \text { e } \quad j=1,2, \ldots, m
\end{gathered}
$$

Em que: a porção $\left(l_{i 1}^{2}+l_{i 2}^{2}+\ldots+l_{i m}^{2}\right)$ explicada pelos $m$ fatores comuns é chamada de i-ésima comunalidade (indica a proporção da variância total da variável que é explicada pelo conjunto de fatores comuns) e a porção $\Psi_{i}$ é chamada de variância específica. 
As cargas fatoriais estimadas podem ser obtidas por vários métodos, neste trabalho foi utilizado o método mais comumente empregado, que é o dos componentes principais, e a rotação ortogonal foi realizada pelo método Varimax. A decisão pelo método de componentes principais se deu por não pressupor que as variáveis sejam normalmente distribuídas. Já a rotação Varimax visa que se maximizem as correlações de cada variável com um fator.

A escolha das variáveis que farão parte da solução é realizada pela análise da matriz de anti-imagem e das comunalidades. A primeira é uma medida da adequação da variável ao modelo fatorial, sendo que valores pequenos na diagonal da matriz sugerem a eliminação da variável. A comunalidade da variável é a variância total desta explicada pelo fator, isto é, a parcela da variância da variável que é partilhada ao menos com outra do conjunto. A decisão de exclusão da variável segue o mesmo critério dos valores da matriz de anti-imagem, quanto menor, mais indicada é a sua retirada. O confronto da matriz de anti-imagem com as comunalidades pode ser conflitante, neste caso, opta-se por seguir o valor das comunalidades.

A adequação do modelo de análise fatorial é avaliada por meio da estatística de KaiserMeyer-Olkin (KMO) e o teste de esfericidade de Bartlett. O KMO é um indicador que compara a magnitude dos coeficientes de correlação observados com as magnitudes dos coeficientes de correlação parcial e varia entre 0 e 1 . Os valores de KMO inferior a 0,5 indicam que o uso da análise fatorial não é apropriado. Por sua vez, o teste de esfericidade de Bartlett testa a hipótese nula de que a matriz de correlação é uma matriz identidade. A rejeição dessa hipótese implica em se reavaliar a utilização do modelo de análise fatorial aos dados.

O número de fatores necessários para representar o conjunto de dados é determinado a partir da análise da contribuição individual e adicional de cada fator para a variância explicada do conjunto de dados. Na literatura, recomenda-se considerar apenas os fatores cuja raiz característica seja maior que a unidade, isto é, aqueles que correspondem a uma proporção da variância superior àquela atribuída a uma variável isolada.

Após a extração dos fatores é indicada na literatura a necessidade da verificação da consistência interna dos fatores. Define-se como consistência interna dos fatores a parcela de variabilidade das respostas dos inquiridos, que provém das diferenças de respostas dos indivíduos. Pestana e Gangeiro (2000) salientam que a variabilidade das respostas pode ocorrer em razão de confusões de interpretação e não reflexo de opiniões diferentes. A importância de inspeção dos testes de consistência interna é, além da citada, também de avaliar a possibilidade 
de construção e utilização de índices. Os índices são novas variáveis quantitativas que podem ser utilizadas em modelos, como os econométricos. O teste de consistência interna dos fatores a ser realizado neste trabalho é o alpha de Crobach. Este teste pode ser entendido como a correlação esperada entre a escala utilizada e outra escala hipotética do mesmo universo, com número igual de itens que mensuram a mesma característica (PESTANA e GANGEIRO, 2000). O valor do coeficiente do teste alpha de Crobach varia de 0 a 1, sendo que uma boa consistência interna requer valor superior a 0,8 .

Por último, a depender dos valores do teste de alpha de Crobach, pretende-se trabalhar com modelo econométrico denominado probit, a fim de se avaliar o impacto dos fatores na opção ocupacional. Para avaliar este modelo, criar-se-á uma variável denominada empresário, que é igual a 1 se o perfil do estudante é ser empresário, e 0, caso contrário. Observa-se que os perfis ocupacionais foram reduzidos a duas classes, empresários ou não, para simplificar. Uma vez que o foco do estudo é determinante do gosto e da intenção empresarial não faz sentido utilizar modelos complexos para se levar em consideração os três perfis considerados nas demais análises, a saber: funcionário da iniciativa privada, funcionário público e empresário. Em razão de o modelo econométrico probit ser comumente utilizado dispensam-se discussões metodológicas a respeito dele. 


\section{RESULTADOS E DISCUSSÃO}

\subsection{Caracterização da amostra}

A amostra a ser estudada é composta por dois grupos de estudantes, um grupo que estava iniciando seu curso universitário e outro que estava terminando seu curso superior. Este último grupo é constituído por indivíduos que estavam diante da decisão de escolha da atividade ocupacional. Ainda vale lembrar que a amostra foi composta por duas instituições, uma denominada de PUB - ESALQ, e outra denominada de PRI.

Os questionários foram aplicados ao grupo de iniciantes no final de fevereiro de 2007 e início de março de 2007, nos primeiros dias das atividades letivas das universidades. Foram aplicados 405 questionários em ambas as escolas, todos pessoalmente. A população de alunos era de 348 na escola PUB - ESALQ, e 228 na escola PRI, assim totalizando 576 discentes. É oportuno salientar que na PUB - ESALQ são admitidos anualmente 390 estudantes; entretanto, com a não matrícula de alguns alunos na primeira chamada, no momento da aplicação dos questionários nesta instituição havia 348 alunos matriculados.

Os alunos formandos das escolas PUB - ESALQ e PRI responderam os questionários no período de novembro de 2006 a janeiro de 2007. No total foram aplicados 209 questionários, tanto pessoalmente quanto via e-mail. A população de formandos pela instituição PUB - ESALQ é estimada em 204 alunos em nível de bacharelado e 22 alunos em licenciatura. Enquanto na instituição PRI o número de formandos é de aproximadamente de 140 alunos. Cabe salientar que o grupo composto pelos bacharéis não é excludente do de licenciados. Na Tabela 2 apresenta-se o total de estudantes ingressantes e formandos e a participação deles em cada curso no total estimado de formandos. 
Tabela 2 - População e participação na população dos alunos ingressantes e formandos pelas instituições PUB - ESALQ e PRI, por curso avaliado

\begin{tabular}{|c|c|c|c|c|}
\hline Curso & $\begin{array}{c}\text { Total de } \\
\text { alunos } \\
\text { ingressantes } \\
\end{array}$ & $\begin{array}{l}\text { Total estimado } \\
\text { de alunos } \\
\text { formandos } \\
\end{array}$ & $\begin{array}{c}\text { Participação do total } \\
\text { de ingressantes na } \\
\text { população }\end{array}$ & $\begin{array}{c}\text { Participação do total } \\
\text { de formandos na } \\
\text { população }\end{array}$ \\
\hline \multicolumn{5}{|l|}{ Ciências } \\
\hline \multicolumn{5}{|l|}{ Biológicas - } \\
\hline Bacharelado & 22 & 7 & 3,82 & 1,91 \\
\hline \multicolumn{5}{|l|}{ Ciências } \\
\hline \multicolumn{5}{|l|}{ Biológicas - } \\
\hline Licenciatura & & 13 & & 3,55 \\
\hline \multicolumn{5}{|l|}{ Ciências dos } \\
\hline Alimentos & 33 & 29 & 5,73 & 7,92 \\
\hline \multicolumn{5}{|l|}{ Ciências } \\
\hline Econômicas & 35 & 14 & 6,08 & 3,83 \\
\hline \multicolumn{5}{|l|}{ Engenharia } \\
\hline Agronômica & 186 & 110 & 32,29 & 30,05 \\
\hline \multicolumn{5}{|l|}{$\begin{array}{l}\text { Só Licenciatura } \\
\text { em Ciências }\end{array}$} \\
\hline \multicolumn{5}{|l|}{ Agrárias } \\
\hline Agronômica) & - & 7 & 0,00 & 1,91 \\
\hline \multicolumn{5}{|l|}{ Engenharia } \\
\hline Florestal & 38 & 23 & 6,60 & 6,28 \\
\hline \multicolumn{5}{|l|}{$\begin{array}{l}\text { Só Licenciatura } \\
\text { em Ciências }\end{array}$} \\
\hline \multicolumn{5}{|l|}{ Agrária } \\
\hline \multicolumn{5}{|l|}{ (Engenharia } \\
\hline Florestal) & - & 2 & 0,00 & 0,55 \\
\hline Gestão Ambiental & 34 & 21 & 5,90 & 5,74 \\
\hline \multicolumn{5}{|l|}{$\begin{array}{l}\text { Sub-total de } \\
\text { formandos pela }\end{array}$} \\
\hline PUB - ESALQ & 348 & 226 & 60,42 & 61,75 \\
\hline \multicolumn{5}{|l|}{ Administração - } \\
\hline Diurno PRI & 64 & 42 & 11,11 & 11,48 \\
\hline \multicolumn{5}{|l|}{ Administração - } \\
\hline Noturno PRI & 134 & 70 & 23,26 & 19,13 \\
\hline \multicolumn{5}{|l|}{ Ciências } \\
\hline Econômicas - PRI & 30 & 28 & 5,21 & 7,65 \\
\hline \multicolumn{5}{|l|}{$\begin{array}{l}\text { Sub-total de } \\
\text { formandos pela }\end{array}$} \\
\hline PRI & 228 & 140 & 39,58 & 38,25 \\
\hline População total & 576 & 366 & 100,00 & 100,00 \\
\hline
\end{tabular}


A determinação do número de questionários a ser aplicado, em princípio, seria igual ao número de alunos das instituições, entretanto, dada a dificuldade de encontrá-los, não foi possível aplicar questionários a toda população. Em virtude de respostas errôneas, alguns dos questionários aplicados não foram considerados como válidos. Foram invalidados dentre os estudantes ingressantes da instituição PUB - ESALQ em torno de 21,8\%, com relação aos questionários aplicados na instituição, e 14,6\% do total de questionários, enquanto da PRI aproximadamente 13,4\% dos questionários da instituição e 4,45\% do total de questionários. Com respeito aos discentes formandos, foram desconsiderados na escola PUB - ESALQ em torno de 15,7\% dos questionários aplicados e 9,7 \% do total de questionários aplicados, e na escola PRI foram 29,3\% dentre os questionários da escola e 11,5\% do total. Desta forma, o número de questionários aplicados válidos totalizou 328 dentre os ingressantes e 165 dentre os formandos. Assim, da população de estudantes ingressantes tem-se 56,9\% da população analisada, sendo a representatividade da amostra de estudantes formandos igual a 45\% da população. Na Figura 12, observa-se os totais de questionários aplicados, válidos e invalidados por grupo analisado e instituição.

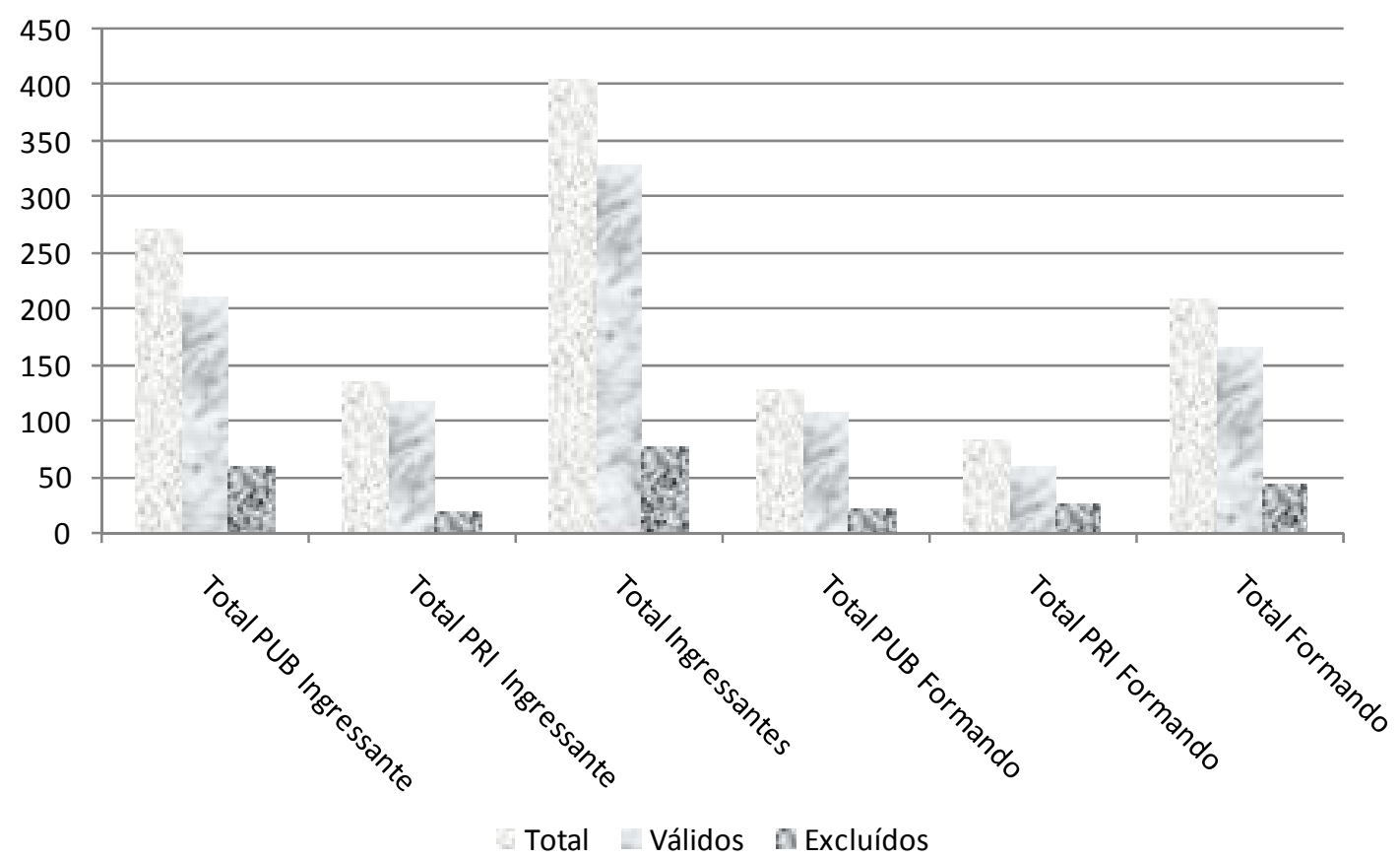

Figura 12 - Questionários: totais, válidos e excluídos

Fonte: Resultado da pesquisa 
O critério de exclusão dos questionários foi a resposta correta à questão 11, que trata da ordenação das opções de ocupação profissional. Os questionários considerados válidos são aqueles em que não havia repetição de números, refletindo assim, uma ordenação lógica das preferências. Considerando-se o índice de perda de questionários, em torno de 19\% entre os ingressantes e $21 \%$ entre os formandos, nota-se uma dificuldade por parte dos alunos em ordenar sua preferência ocupacional. Cabe salientar que devido à alta taxa de questionários invalidados na primeira fase, a aplicação entre os formandos, na fase subseqüente, isto é, a aplicação entre os ingressantes, foi enfatizado na entrega dos questionários que os alunos tomassem cuidado em não repetir números no ordenamento das opções da questão 11. No entanto, mesmo com a explicação adicional a taxa não apresentou significativa redução, indicando, assim, dificuldade na identificação das atividades que são preferidas.

A participação de cada curso dentre os questionários aplicados válidos dos alunos ingressantes e dos alunos formandos está apresentada na Figura 13. 
Alunos Ingressantes

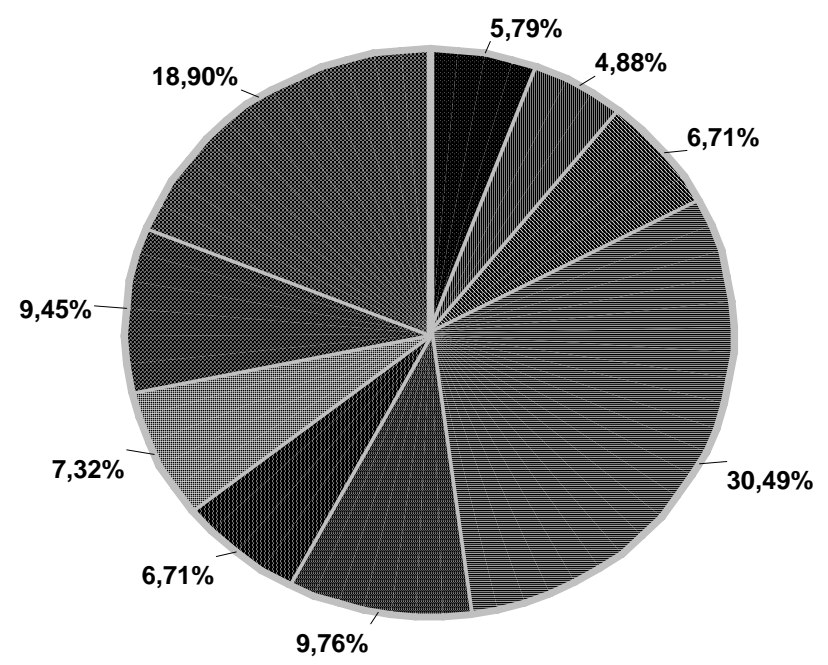

Alunos Formandos

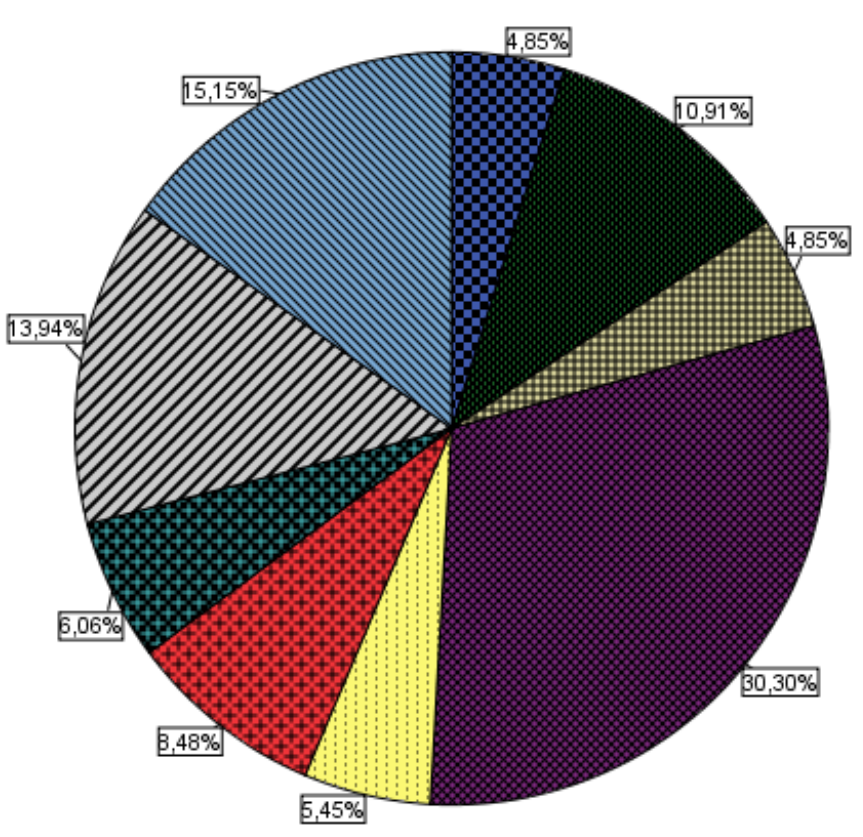

Curso

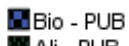

Ali - PUB

田Eco - PUB

Agro - PUB

田Ges - PUB

ECo - PRI

ZAdm Diur - PR

$\mathbb{N}$ Adm_N - PRI

Figura 13 - Cursos: participação dos cursos avaliados dentre os questionários aplicados Fonte: Resultados da pesquisa 


\subsection{Preferências ocupacionais dos estudantes}

A exclusão de questionários sob o critério adotado de ordenação sem repetição permitiu a descrição da amostra por uma variável denominada tipo. Esta variável qualitativa representa três categorias: funcionários de iniciativa privada, funcionário público e empresário. A construção da variável tipo foi realizada a partir da crença dos ingressantes e formandos quanto à ocupação que estarão ocupando em, respectivamente, 12 e 7 anos. A ocupação que foi elencada como a primeira opção dentre as alternativas do questionário determinou a classificação como funcionário de iniciativa privada ou funcionário público ou empresário. Na Tabela 3 apresenta-se a relação primeira escolha e classificação do tipo ocupacional.

Tabela 3 - Definição do tipo ocupacional dada à primeira opção assinalada

\begin{tabular}{lc}
\hline \multicolumn{1}{c}{ Ocupação } & Tipo Ocupacional \\
\hline Trabalhando numa empresa nacional ou multinacional & Funcionário da iniciativa privada \\
Trabalhando num instituto de pesquisa & Funcionário Público \\
Trabalhando numa universidade ou escola técnica & Funcionário Público \\
Trabalhando com assistência técnica e extensão rural & Funcionário Público \\
Trabalhando em outra atividade do setor público & Funcionário Público \\
Gerindo um negócio seu que não tenha sócios & Empresário \\
Gerindo negócio(s) de sua família & Empresário \\
Sócio de um negócio & Empresário
\end{tabular}

Fonte: Elaborado pela autora

Na Tabela 3 está associada a escolha pela ocupação e a determinação do tipo ocupacional. Por exemplo, o estudante que escolheu como primeira opção a alternativa trabalhando em uma empresa nacional ou multinacional foi classificado como funcionário de iniciativa privada. Cabe salientar que com a proposta metodológica, há diferença entre o significado de gosto e de crença; assim, pode não haver correspondência entre o perfil de gosto ocupacional e o perfil de crença ocupacional.

O desejo dos estudantes ingressantes é predominantemente ser funcionário da iniciativa privada, em torno de 44,8\%. O grupo daqueles que gostariam de ser funcionários públicos é o segundo maior, com 33,5\%, e com menor percentual, em torno de $21,6 \%$ tem-se o grupo 
daqueles que têm como desejo desempenhar atividades empresariais. Com relação à crença do que estarão desempenhando no futuro, os estudantes ingressantes mantiveram o mesmo ordenamento do que desejam. No entanto, com relação aos funcionários da iniciativa privada e funcionário público houve variação dos percentuais. Com a crença de que serão funcionários da iniciativa privada houve redução, em torno de 40,9\% dos estudantes declararam que acreditam que estarão ocupando posições como funcionários no setor privado. Já com respeito à crença de serem funcionários públicos, o grupo aumentou, em torno de 37,5\% acreditam que estarão prestando serviço para o setor público. O grupo com interesse em primeiro lugar de desempenhar atividades empresariais manteve-se com o mesmo percentual daqueles com o gosto de serem empresários.

A análise da preferência ocupacional entre os formandos apresentou resultados diferentes dos ingressantes tanto na ótica de gosto como na de intenção. Com relação ao gosto, o maior grupo é composto por aqueles que têm como primeira opção ser funcionários públicos, em torno de 40,6\%, seguidos pelos que gostariam de ser empresários, cerca de 36,4\% e com menor participação é o desempenho de atividades como funcionário do setor privado, cerca de 23,0\%. A crença dos formandos não segue o comportamento da amostra dos alunos ingressantes, em que houve aumento com respeito ao desempenho de funções no setor público. Houve uma redução de significativa magnitude entre os formandos quanto a trabalharem no setor público, em torno de 23,6\% acreditam que estarão trabalhando como funcionários públicos. A maior parte dos formandos acreditam que estarão trabalhando como funcionários do setor privado, em torno de 42,4\%. O grupo daqueles que acreditam que estarão desempenhando atividades empresariais apresentou redução em relação ao gosto, em torno de 33,9\% dos estudantes acreditam que serão empresários. Na Tabela 4 apresentam-se estes resultados.

Tabela 4 - Percentual da escolha dos estudantes pelos perfis considerados

\begin{tabular}{lcccc}
\hline \multirow{2}{*}{ Perfil Ocupacional } & \multicolumn{2}{c}{ Alunos Ingressantes } & \multicolumn{2}{c}{ Alunos Formandos } \\
\cline { 2 - 5 } & Gosto & Acredita & Gosto & Acredita \\
\hline Funcionário Privado & $44,8 \%$ & $40,9 \%$ & $23,0 \%$ & $42,4 \%$ \\
Funcionário Público & $33,5 \%$ & $37,5 \%$ & $40,6 \%$ & $23,6 \%$ \\
Empresário & $21,6 \%$ & $21,6 \%$ & $36,4 \%$ & $33,9 \%$ \\
\hline
\end{tabular}

Fonte: Resultado da pesquisa 
A análise dos dados revela que durante o período em que ficam no curso superior há uma mudança no gosto e na crença dos estudantes. Tal afirmação é feita com base nos resultados do teste de qui-quadrado, que indicaram que as diferenças são estatisticamente significativas. O valor do teste de qui-quadrado para as freqüências associadas ao gosto foi igual a 24,362; assim com ao nível de signficância de $1 \%$ rejeita-se a hipótese de que não há diferença entre os estudantes ingressantes e formandos quanto à formação do desejo pelas ocupações profissionais consideradas. Com relação à crença, teve-se resultado semelhante, o valor do teste de quiquadrado foi igual a 12,926. Como o nível de significância do teste de qui-quadrado para a crença foi de 0,002, valor inferior a 0,01, rejeita-se a hipótese de que as freqüências não são significantemente diferentes. O percentual associado ao gosto por atividades empresariais aumentou, entretanto, se os estudantes ingressantes gostam da idéia e acreditam que serão empresários, o mesmo não acontece com os formandos. Alguns dos formandos gostariam de ser empresários, mas não acreditam que serão.

A análise pormenorizada dos perfis ocupacionais dos estudantes ingressantes e formandos, tanto por instituição quanto por curso é discutida a seguir. Na Figura 14 apresenta-se o perfil ocupacional que a amostra de estudantes ingressantes e formandos gostariam e acreditam ocupar por instituição. 
Gosto: Alunos Ingressantes

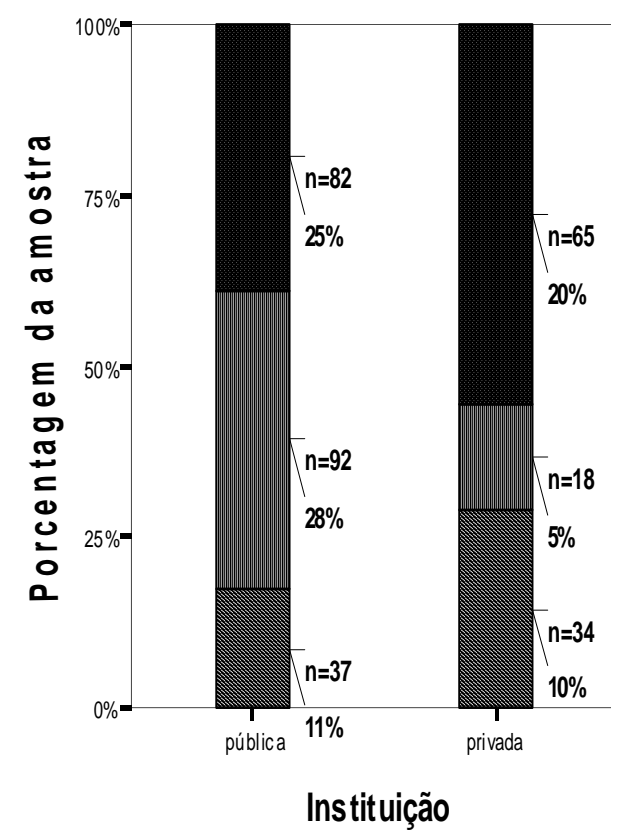

Gosto: Alunos Formandos

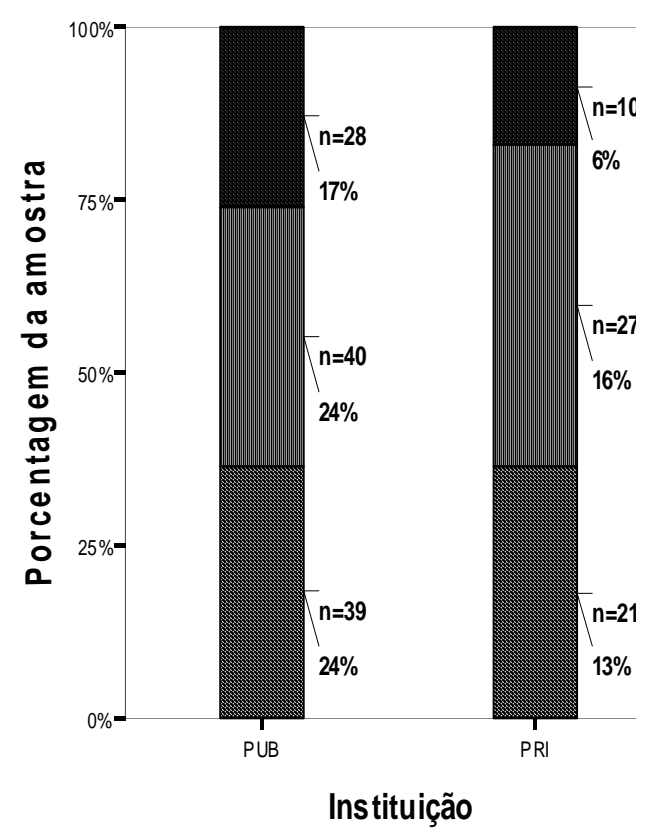

Acredita: Alunos Ingressantes

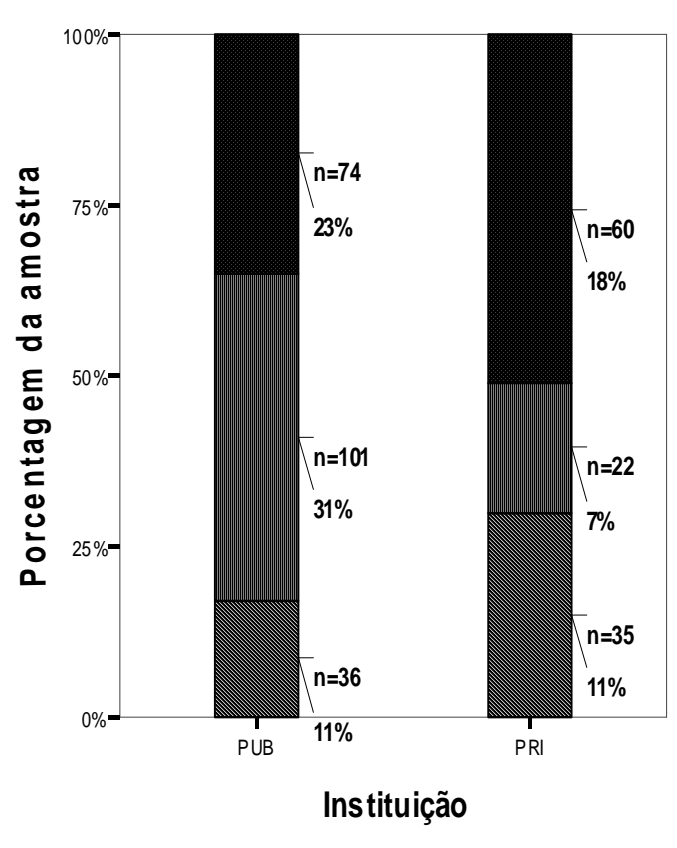

Acredita: Alunos Formandos

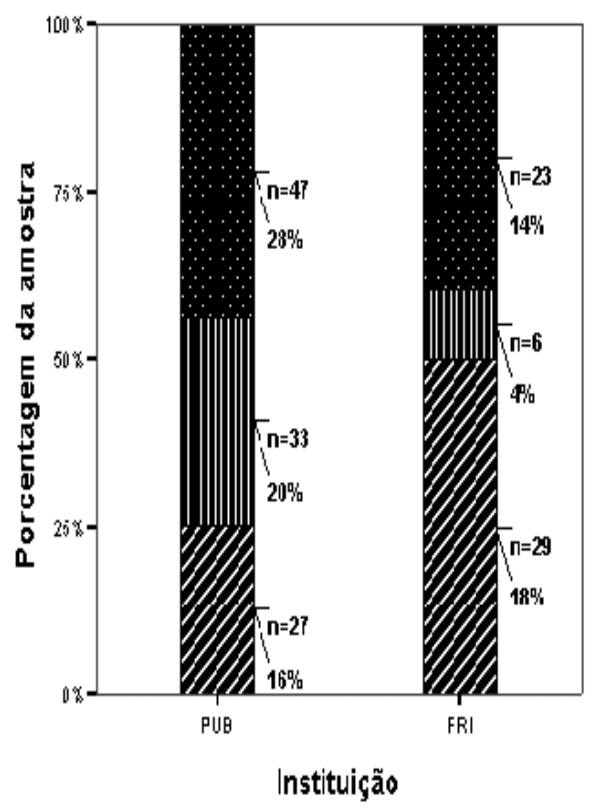

Tipo Ocupacional

$\because$ Funcionário Iniciativa Privada III Funcionário Público T/. Empresario

Figura 14 - Percentual, por instituição, do perfil ocupacional dos estudantes amostrados 
Na Figura 14 estão apresentados os gostos e as crenças dos estudantes ingressantes e formandos com relação a sua ocupação profissional no futuro. Em primeiro lugar, os rótulos de percentuais associados às barras são referentes ao total da amostra, assim, dos ingressantes consideram-se 328 observações, e dos formandos, 165 observações. Na instituição PUB ESALQ verifica-se a atração de indivíduos que desejam ser funcionários públicos, em torno de 43,6\% dentre os ingressantes nesta instituição declararam que gostariam de desempenhar atividades relacionadas a cargos públicos. O grupo dos que desejariam ser funcionários da iniciativa privada contém 38,7\% dos alunos ingressantes. O percentual daqueles que gostariam de desempenhar atividade empresarial é o menor dentre as demais ocupações, aproximadamente 17,5\% de alunos ingressantes da instituição PUB - ESALQ gostariam de ser empresários. Com relação à crença, verifica-se que o percentual de alunos que acreditam que se tornarão funcionários públicos após terminarem seus cursos universitários aumenta aproximadamente quatro pontos percentuais. O grupo que acredita que serão empresários é estável, havendo uma redução de 0,5 pontos percentuais, assim como aqueles que acreditam que trabalharão para a iniciativa privada como funcionários.

Os desejos e crenças dos alunos que ingressam na instituição PRI são diferentes daqueles que iniciam seu curso na instituição PUB - ESALQ. Com relação ao gosto destes alunos, o maior grupo é formado por aqueles que desejam ser funcionários da iniciativa privada, em torno de 55,5\% da amostra dos alunos da PRI. O segundo grupo em representatividade é constituído pelos que gostariam de desempenhar atividades empresariais, aproximadamente 29,0\%. Enquanto o grupo com aqueles com o desejo de ser funcionário público são em torno de 15,4\%, percentual em muito inferior quando comparado ao verificado na instituição PUB - ESALQ. A crença dos alunos ingressantes da instituição PRI manteve sem significativas alterações na participação por tipo ocupacional. Os que acreditam que serão empresários são em torno de 29,9\%, os que acreditam que serão funcionários da iniciativa privada, em torno de 51,9\%,e os com crença que conseguirão um cargo público perfazem 18,8\%.

A análise dos desejos e das crenças dentre os alunos formandos revelou algumas mudanças quando comparadas aos desejos e às crenças dos alunos ingressantes. Na instituição PUB ESALQ os formandos que gostariam de conseguir um cargo público continuaram a ser o maior grupo, em torno de $37,4 \%$. O segundo maior grupo passou a ser representado por aqueles que gostariam de ser empresários, aproximadamente 36,5\%. Já os que gostariam de ser funcionários 
da iniciativa privada são em torno de 26,2\%. Com respeito ao que acreditam, dentre os alunos da escola PUB - ESALQ, o grupo com maior percentual é dos que acreditam que estarão ocupando posições como funcionários da iniciativa privada, em torno de 43,9\%. Os que acreditam que estarão atuando para o setor público são em torno de 30,9\% e atuando como empresário 25,2\%. Assim, nota-se que comparando-se os resultados entre os ingressantes e formandos da escola PUB - ESALQ houve um significativo aumento dos percentuais associados ao empreendedorismo, apesar de ainda não representar o maior grupo. No entanto, se dentre os ingressantes os resultados referentes ao gosto e à crença de ser empresário apresenta redução em pequena magnitude, com respeito aos formandos o diferencial é maior, em torno de 11,3 pontos percentuais. Os cargos públicos continuam a ser desejados por muitos estudantes da escola PUB ESALQ, mas nota-se uma descrença quanto à intenção de ocupá-los. Ainda, observa-se que uma parcela dos estudantes formandos possivelmente desempenhará uma atividade para a qual não tem vontade. Os resultados relacionados ao gosto de atuar como funcionário na iniciativa privada e à intensão de atuar como funcionário na iniciativa privada são de magnitudes diferentes. O percentual daqueles que gostariam é de 26,2\%, e o valor referente à crença de que estarão atuando na iniciativa privada é igual a 43,9\%. Uma hipótese aventada para explicar este resultado é que o treinamento oferecido pela ESALQ tem um padrão de excelência que é fundamental para a atuação na iniciativa privada. Assim, os estudantes têm a expectativa de que não enfrentarão dificuldades em atuar como funcionários da iniciativa privada, mesmo tendo outras preferências ocupacionais.

Com respeito aos alunos que estavam concluindo seus cursos superiores na instituição PRI, a ocupação mais desejada entre os estudantes desta escola é associada ao setor público. O grupo que deseja ter um cargo público representa em torno de 46,5\% da amostra dos alunos desta universidade. Com segunda maior participação, estão aqueles que gostariam de desenvolver atividades empresariais, em torno de 36,2\%. A preferência por trabalhar como funcionário da iniciativa privada tem menor desejabilidade entre os formandos, aproximadamente 17,2\%. Observa-se que com relação à crença, o maior grupo é dos que acreditam que desempenharão atividades empresariais, 50\%, seguidos por trabalhar como funcionário da iniciativa privada, 39,6\%, e por último, cargos públicos, com 10,4\%. A comparação entre o gosto e a crença dos formandos da PRI revela que há uma descrença quanto à possibilidade de que o desejo se torne intenção entre aqueles que gostariam de serem funcionários públicos. Além disso, verifica-se um 
aumento da crença de se tornar um empresário, bem como de ocupar um cargo de funcionário da iniciativa privada.

A comparação entre as escolas PUB - ESALQ e PRI revela que existem processos similares entre os alunos de ambas as escolas. Esta afirmação é defendida com base nos resultados do teste de qui-quadrado para as freqüências das respostas dos alunos da escola PUB - ESALQ e PRI. Considerando os alunos ingressantes e formandos da escola PUB - ESALQ tem-se que o valor do teste de qui-quadrado com relação ao gosto pelas ocupações profissionais consideradas foi igual a 14,595. Com respeito à crença, o valor do teste de qui-quadrado foi igual a 8,740. As relações consideradas entre o gosto e crença dos alunos ingressantes e formandos da escola PUB - ESALQ são estatisticamente significantes ao nível de significância de 0,001 e 0,013, respectivamente. Desta forma, as relações com relação ao gosto são significantes ao nível de 1\%, e referentes à crença ao nível de 5\%. Os resultados do teste de qui-quadrado para os alunos ingressantes e formandos da escola PRI para o gosto por ocupações profissionais consideradas foi de 28,561, e para a crença, igual a 7,117. A hipótese de que as freqüências das respostas para o gosto e a crença não são diferentes é rejeitada ao nível de significância de 1\% e 5\%, respectivamente. Dados os resultados do teste de qui-quadrado que confirmam que há diferença entre as freqüências obtidas, afirma-se que o percentual daqueles que gostariam de ter uma atividade empresarial aumentou em ambas as escolas quando se comparam ingressantes e formandos. No entanto, quando são analisados os fatores "gostaria" e "acredita”, nota-se que na escola PUB ESALQ tanto entre ingressantes quanto entre formandos há redução daqueles que gostariam para os que acreditam que desempenharão uma atividade empresarial. Mas, dentre os alunos da escola PRI há uma aumento quando se compara o grupo que desejaria e o grupo que acredita que estará desenvolvendo uma atividade empresarial. Com respeito aos cargos públicos verifica-se que se dentre os ingressantes a crença de conseguir, apesar de não desejarem é maior, já dentre os formandos tal visão não se verifica, a comparação entre desejo e crença revela uma redução da participação. O trabalho como funcionário da iniciativa privada para os formandos representa um refúgio, já que, apesar de não desejarem, muitos acreditam que ocuparão posições de funcionário do setor privado. O diferencial entre o gosto e a crença entre os formandos de ocupar uma posição como funcionário no setor privado é na escola PUB - ESALQ de 17,7 pontos percentuais e na escola PRI de 22,4\%. 
Na Figura 15 são apresentados os resultados dos perfis ocupacionais por curso entre os ingressantes.

\section{Gostaria}

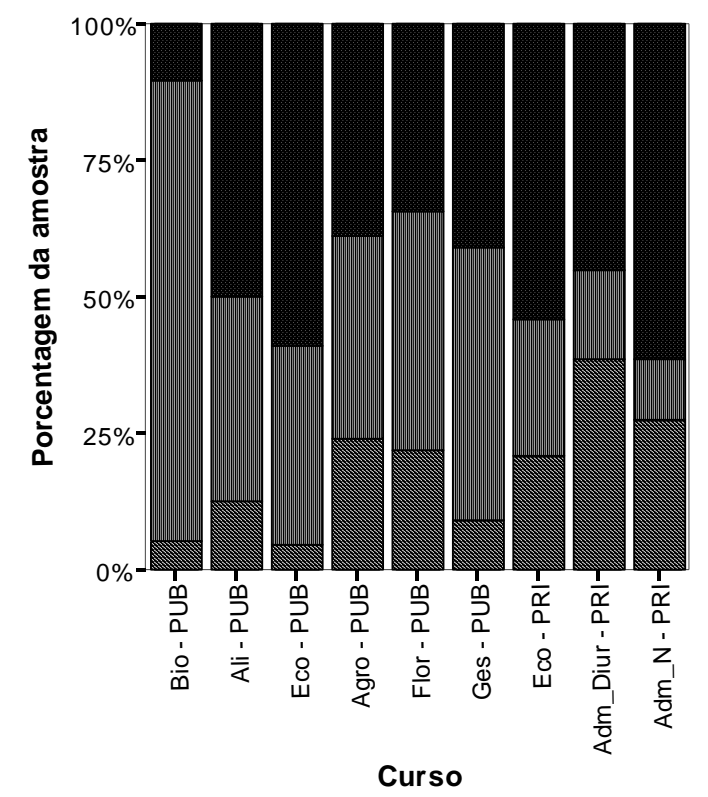

Acredita
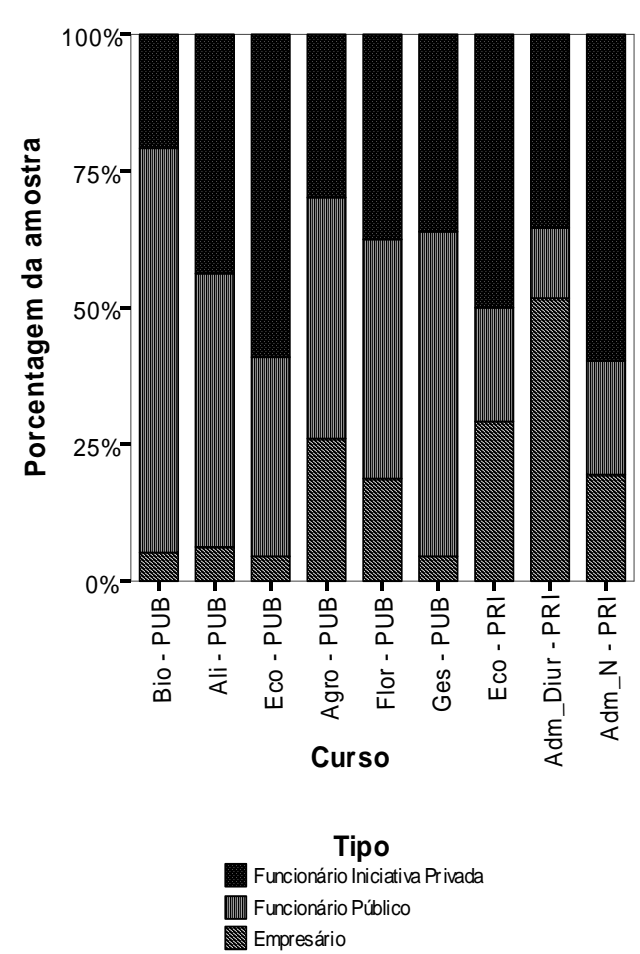

Figura 15 - Percentual do tipo ocupacional dos ingressantes, por curso Fonte: Resultado da pesquisa

O curso que reúne o maior número de estudantes ingressantes com gosto e intenção de desempenhar atividades empresariais é o curso de Administração Diurna da escola PRI, com respectivamente, 38,7\% e 51,6\%. Na universidade PUB - ESALQ os cursos com maior número de ingressantes com desejo e crença de serem empresários são Eng. Agronômica e Eng. Florestal. Dos alunos ingressantes em Engenharia Agronômica, 24\% têm o desejo de atuar com empresários e 26\% acreditam que serão empresários. No curso de Ciências Biológicas encontrase o maior percentual de ingressantes com aspiração e intenção de serem funcionários públicos, respectivamente, 84,2\% e 73,7\%. O perfil profissional dos estudantes de Ciências Econômicas 
entre as universidades PUB - ESALQ e PRI são diferentes. Na universidade PRI há maior número de estudantes ingressantes neste curso com desejo e intenção de ser empresários. Comparando os percentuais das escolas PRI e PUB - ESALQ, o gosto por atividades empresariais nas escolas é respectivamente, 20,8\% e 4,5\%, e de crença nas escolas PRI e PUB - ESALQ, respectivamente, $29,2 \%$ e $4,5 \%$.

Na Figura 16 está a análise do perfil profissional dos formandos considerando-se o curso superior deles.

Gostaria

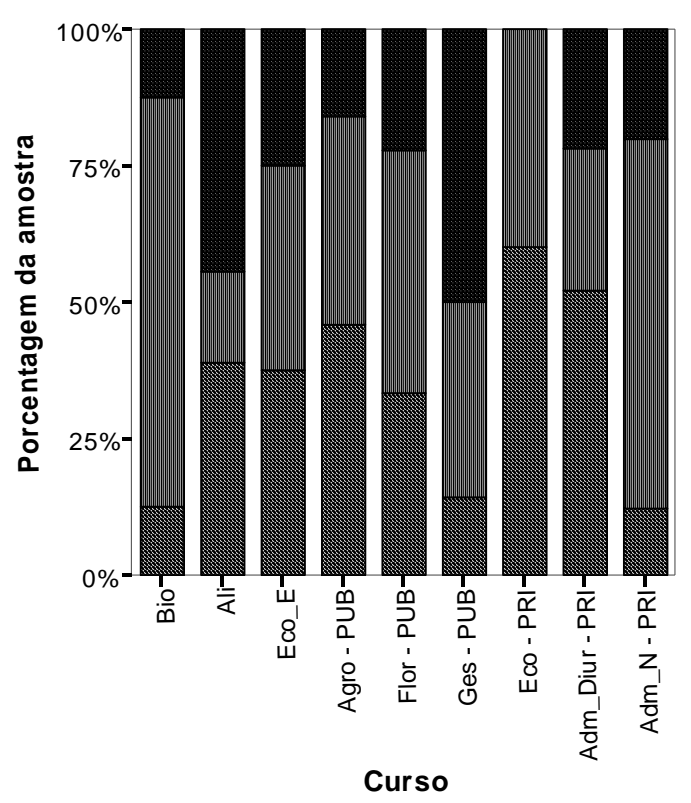

Acredita
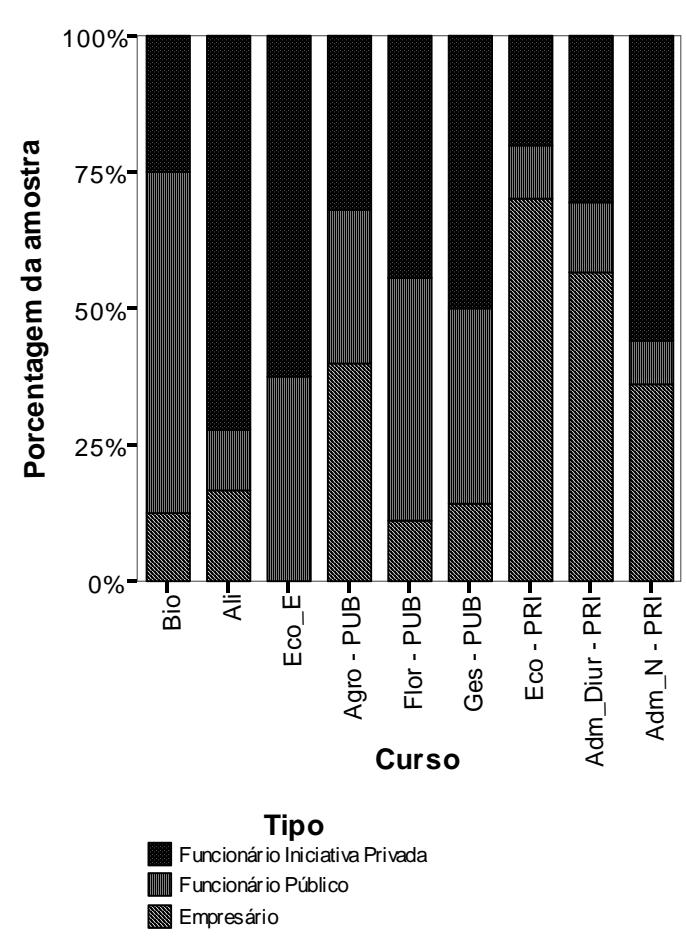

Figura 16 - Percentual do tipo ocupacional dos alunos formandos, por curso

O curso de Economia da escola PUB - ESALQ há estudantes de economia que gostariam de desenvolver atividades empresariais, 37,5\%, entretanto, nenhum desses indivíduos tem intenção de desenvolver atividades empresariais. Comparando-se os resultados com os estudantes de Ciências Econômicas da universidade PRI verifica-se um diferencial de perfil, pois nesta, além de 
o percentual de estudantes formandos que gostariam de ser empresários ser superior ao da escola PUB - ESALQ, o número de estudantes de acreditam que serão empresários é ainda maior do que aqueles que gostariam de ser. O curso de Ciências Econômicas da escola PRI destaca-se em comparação com os demais cursos no número de formandos em relação ao gosto, 60\%, e a intenção, 70\%, de serem empresários. Na escola PUB - ESALQ verifica-se que tanto entre os que desejam quanto os que acreditam o maior percentual de estudantes é do curso de Engenharia Agronômica, respectivamente, 46\% e 40\%.

Utilizando-se o teste de qui-quadrado para a freqüência das respostas dos alunos ingressantes e formandos de Agronomia com relação a gosto e crença pelas ocupações consideradas, rejeita-se a hipótese de não diferença para as freqüências com relação ao gosto. Mas, para a crença, não se rejeita a hipótese de não haver diferença entre as freqüências das respostas dos alunos do curso de Agronomia. O nível de significância do teste de qui-quadrado para a freqüência das respostas dos alunos ingressantes e formandos com relação ao gosto foi igual a 0,005 , enquanto para a crença foi de 0,112 . Assim, se para a formação do gosto dos alunos de Agronomia pode-se afirmar que a escola PUB - ESALQ tem influência, o mesmo não se pode concluir com relação à influência da escola PUB - ESALQ na formação da crença dos alunos deste curso. A análise do teste de qui-quadrado da freqüência das respostas dos alunos da escola PRI, considerando o curso, só foi possível para o gosto e a intenção dos alunos do curso de Administração Noturna. Para os cursos de Administração Diurna foi possível considerar os resultados do teste de qui-quadrado para o gosto pelas ocupações profissionais consideradas. Os resultados do teste de qui-quadrado para a crença dos estudantes do curso de Administração Diurna e Ciências Econômicas não foram apresentados. O motivo é que nestes cursos encontraram-se freqüências esperadas inferiores a cinco em mais de $20 \%$ das células de contagem das freqüências. Conforme apresentado na metodologia, tal resultado viola o pressuposto do teste de qui-quadrado. No curso de Administração Noturna tem-se que a escola PRI influencia na formação do desejo pelas ocupações profissionais dos estudantes. Dado o nível de significância do teste de qui-quadrado de 0,000, rejeita-se a hipótese de não haver diferença entre as freqüências das opções ocupacionais. Mas, para a formação da crença e as freqüências das respostas entre os estudantes ingressantes e formandos não são estatisticamente significativas. O p-valor do teste de qui-quadrado foi igual a 0,148 . 
Nas Figura 17 e Figura 18 estão destacados em quais perfis ocupacionais há maior crença de não ser possível desempenhar a carreira desejada. Em cada uma delas são apresentados dois painéis, o primeiro retrata o percentual da amostra cuja opção ocupacional que acredita desempenhar corresponde à ocupação ocupacional que gostaria de desempenhar, e outro mostra a parcela de estudantes que não estarão desempenhando a atividade que gostariam.
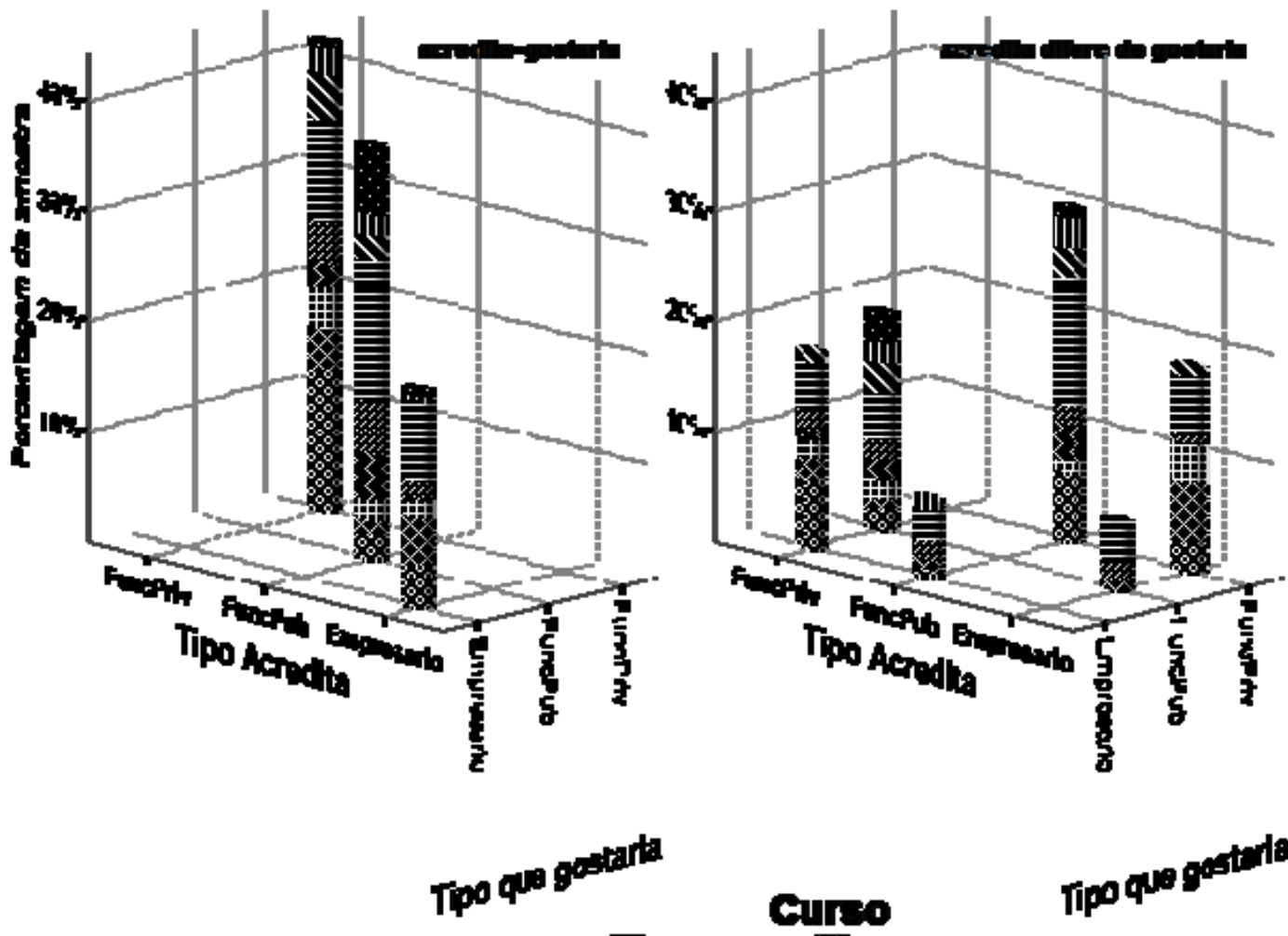

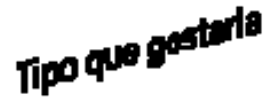

Curso

Tipoq

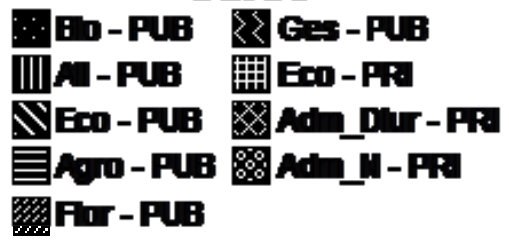

Figura 17 - Porcentagem de estudantes ingressantes por opção ocupacional que acredita que ocupará a opção que gostaria de desempenhar

Fonte: Resultados da pesquisa 
A verificação entre os estudantes que estão iniciando o seu curso universitário se o gosto e a crença por desempenhar uma ocupação no futuro é coincidente revelou que em torno de 65,9\% dos alunos acreditam que conseguirão desempenhar a atividade que gostariam. O maior percentual de correspondência entre gosto e crença está entre aqueles que têm perfil funcionário de iniciativa privada, em torno de 42,6\% daqueles que acreditam que desempenharão a atividade de seu desejo. O grupo que gosta e acredita que desempenhará atividades empresariais é o de menor participação no grupo em que o gosto corresponde à crença, aproximadamente 19,9\%. Comparando-se as escolas PUB - ESALQ e PRI quanto ao número de estudantes que confiam que conseguirão desempenhar a atividade que desejam verifica-se que em ambas as escolas o percentual de estudantes é semelhante. As observações da escola PUB - ESALQ são 211 e destes, 139 acreditam que desempenharão a atividade que gostam, em torno de 65,9\%, e na escola PRI, o resultado foi semelhante, das 117 observações, para 77 o gosto é igual à crença, ou seja, 65,8\%.

Com respeito ao grupo em que não há crença de ser possível atuar na atividade que deseja, há predominância daqueles que gostariam de atuar no setor público. Dos estudantes que gostariam de atuar no setor público e não acreditam que conseguirão, em torno de 75,9\% acreditam que estarão trabalhando como funcionários no setor privado. Do grupo formado por alunos que gostariam de ser empresários, mas não acreditam que serão, em torno de 71,4\% acreditam que estarão trabalhando como funcionários na iniciativa privada. Ainda, tem-se que aproximadamente 38,2\% dos que gostariam de ser funcionários da iniciativa privada acreditam que serão empresários.

O p-valor do teste de qui-quadrado para as freqüências coincidentes das respostas dos alunos ingressantes e formandos quanto ao gosto e à crença por desempenhar uma ocupação pode ser rejeitado ao nível de 15\% de significância. O valor do teste de qui-quadrado foi de 2.364 . O pvalor associado igual a 0,124 para a tabela de contigência que avalia as freqüências das respostas dos estudantes ingressantes e formandos, cuja opção do gosto por desempenhar uma ocupação profissional é igual à opção da atividade que acreditam que desempenharão. Desta forma, as relações discutidas a seguir são estatisticamente significativas ao nível de significância de 15\%. O percentual de estudantes formandos que acreditam que desempenharão a atividade que gostam é menor que o dos estudantes ingressantes. O grupo dentre a amostra de formandos em que gosto e crença são iguais corresponde a 58,8\%. Dentre os estudantes formandos em que há crença de que a atividade desejada será a atividade desempenhada, os que desejam ser empresários 
revelaram maior confiança em desempenhar a atividade que gostariam. O grupo de estudantes formandos que gostariam de ter atividades empresariais e acreditam que desempenharão estas atividades corresponde a 38,1\%. Para os demais perfis houve empate, isto é, 30,9\% dos que gostariam de ser funcionários públicos acreditam que estarão trabalhando no setor público, o mesmo resultado para os de perfil funcionário da iniciativa privada. O grupo de estudantes mais confiantes de que seu desejo será possível é o da escola PUB - ESALQ, dos 107 alunos analisados, para 70 estudantes o gosto é igual crença, em torno de 65,4\%, enquanto da escola PRI, das 58 observações, 27 acreditam que o gosto corresponde à crença. Na Figura 18 são apresentados os resultados dos estudantes formandos.

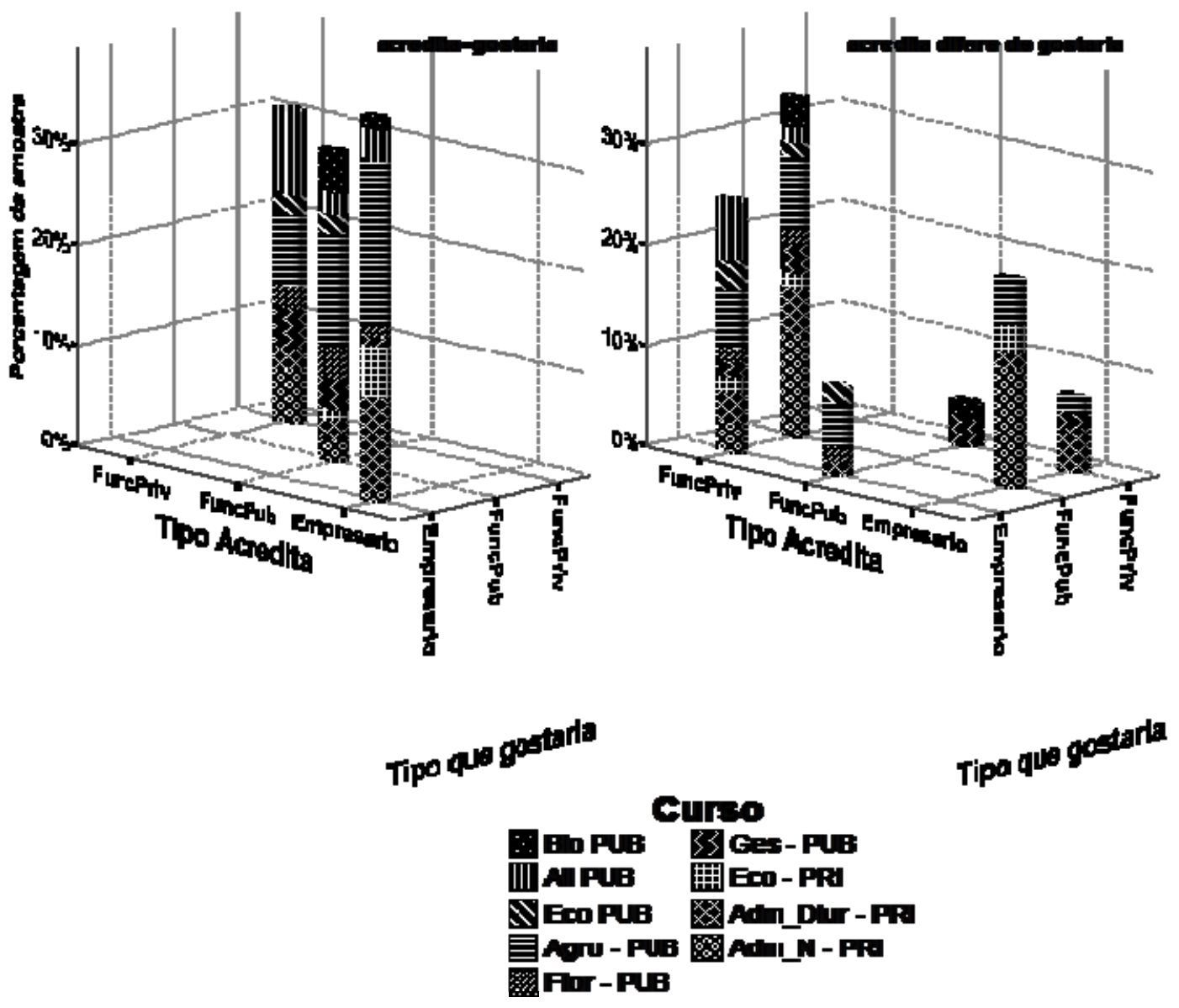

Figura 18 - Porcentagem de formandos por opção ocupacional que acredita que ocupará a opção que gostaria de desempenhar 
No grupo formado por estudantes formandos em que o gosto não corresponde ao que acreditam que estarão ocupando há predominância dos que desejavam ocupar um cargo público. Verifica-se que dentre aqueles que gostariam de ser funcionário público, mas não acreditam que atuarão nesse setor, aproximadamente $62,2 \%$ esperam estar trabalhando na iniciativa privada como funcionários e 37,8\% atuando como empresários. A investigação com relação aos que gostariam de ser empresários, mas não acreditam que serão, indica que 73,9\% acreditam que estarão prestando serviço para a iniciativa privada como funcionários e 26,1\% que estarão no serviço público. O maior número de estudantes que gostariam de serem empresários, mas não acreditam que serão é encontrado na escola PUB - ESALQ. O número de estudantes formandos da escola PUB - ESALQ que gostariam de ser empresários é igual a 39, destes, 43,6\% não acreditam que atuarão como empresários. O gosto pelo perfil empresarial foi identificado em 21 estudantes da escola PRI, destes, 28,5\% não acreditam que atuarão como empresários.

Procedendo à análise por curso, encontrou-se que na escola PUB - ESALQ, formandos do curso de Engenharia Agronômica são os que têm maior confiança de poder exercer seu gosto por atividades empresariais. No curso de Engenharia Agronômica o percentual daqueles que gostariam, mas não acreditam ser possível ser empresário é de 30,4\%. Nos cursos de Ciências Econômicas, Engenharia Florestal, Ciências dos Alimentos, Gestão ambiental da escola PUB ESALQ verifica-se que o percentual de descrença quanto à realização de seu desejo de ser empresário é de, respectivamente, 100\%, 66,6\%, 57,1\% e 50,0\%. Na escola PRI observa-se que nos cursos de Administração Noturna, Administração Diurna e Ciências Econômicas o percentual de descrença quanto a atuar como empresário, apesar de desejar sê-lo, é respectivamente, 66,7\%, $25,0 \%$ e $16,7 \%$.

\subsection{Análise Estatística}

As análises das variáveis qualitativas consideradas na coleta de dados são apresentadas a seguir. O objetivo destas é apresentar o perfil ocupacional por curso avaliado, considerando-se as variáveis indicadas na literatura como relevantes na escolha ocupacional dos indivíduos. Esta análise é apresentada separadamente para os alunos ingressantes e para os alunos formandos. 


\subsubsection{Análise Estatística da amostra de estudantes ingressantes}

Com respeito à variável gênero verifica-se que as mulheres não são a maioria dentre os formandos, entretanto, a diferença entre homens e mulheres não é discrepante. A participação das mulheres no total de formandos é de 45,1\%. Entretanto, verifica-se que em cursos como Ciências dos Alimentos, Ciências Biológicas e Gestão Ambiental há predominância de mulheres, respectivamente 87,5\%, 68,4\% e 59,1\%. Na Figura 19 apresenta-se a distribuição, por curso, do interesse por uma ocupação profissional, considerando-se o gênero.

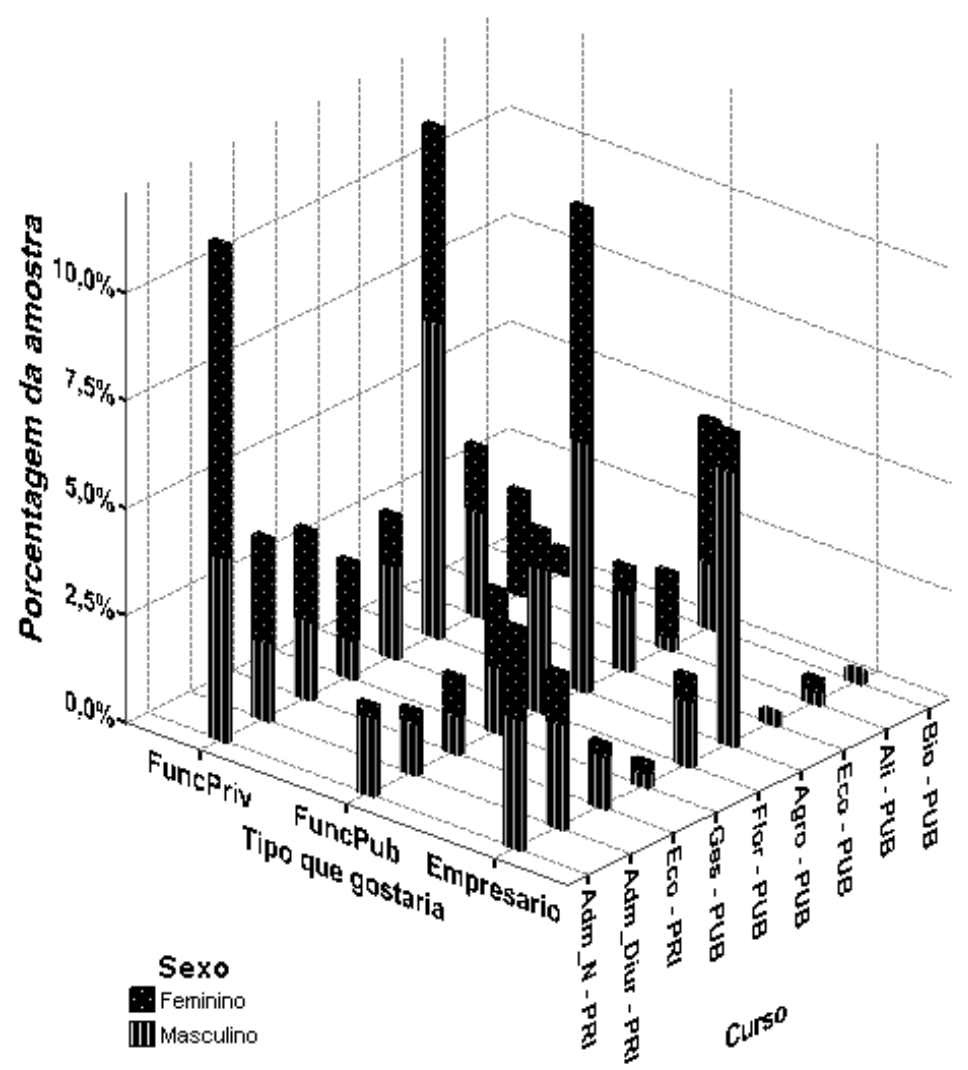

Figura 19 - Porcentagem de alunos ingressantes por opção ocupacional que gostaria de desempenhar e curso considerando-se o gênero

Fonte: Resultados da pesquisa.

$\mathrm{Na}$ literatura é discutido que as mulheres têm menor preferência por ocupações empresariais quando comparadas aos homens. Os motivos apontados são diversos, desde questões relacionadas à percepção de auto-eficácia até discriminação. Considerando-se o gênero feminino, as mulheres têm preferência por ocupar cargos na iniciativa privada como funcionários, 
seguido por serviços públicos e empresariais, respectivamente, 53,4\%, 33,8\% e 12,8\%. Dos 71 estudantes que apontaram o desejo de ser empresários, as mulheres representam 26,8\%. O gênero masculino segue uma ordem de preferência igual ao das mulheres, porém, há maior equilíbrio na distribuição. Entre os homens verifica-se que 37,8\% têm preferência por ser funcionário da iniciativa privada, 33,3\% por ser funcionários público e 28,9\% por ser empresário.

Analisando-se a crença de se tornar empresário no futuro, por gênero, verifica-se que há uma pequena variação nos percentuais. Com relação ao gênero, no grupo em que acreditam que serão empresários, em torno de 33,8\% são mulheres. A maioria das mulheres acreditam que atuarão como empregadas da iniciativa privada, 43,9\%, seguido por serviço público, 39,9\% e atividades empresariais, $16,2 \%$. A comparação entre o gosto por atuar na iniciativa privada como funcionário e a crença de trabalhar no setor privado como funcionário apresentou redução, sendo que a maior parte daquelas que acreditam não ser possível atuar na atividade desejada acredita que trabalhará no serviço público. O acréscimo na atividade empresarial, quando comparado ao percentual que gostaria e o que acredita foi de 3,4 pontos percentuais. O gênero masculino também apresentou mudança de comportamento quando se compara o gosto com a crença. A distribuição da crença entre os perfis profissionais é de 38,3\% na iniciativa privada como funcionários, 35,6\% no serviço público e 26,1\% em atividades empresariais. No grupo com alunos que acreditam que serão empresários, também com 71 observações, a participação masculina se reduziu, sendo igual a $66,2 \%$. Tal resultado contraria a literatura, uma vez que uma das defesas utilizadas para justificar o menor número de mulheres que optam por ser empresárias é a de que não têm auto-confiança; os homens teriam maior auto-confiança.

Com relação à cidade de origem dos estudantes o maior percentual é de estudantes de Piracicaba. As cidades com maior número de estudantes são Piracicaba, São Paulo e Campinas, com respectivamente; 22,6\%, 15,2\% e 4,9\%. A maioria dos estudantes são naturais de São Paulo, em torno de 92,1\%; os estados que seguem em maior participação são Minas Gerais, com 3,0\% e Paraná, com 1,8\%. Dos alunos piracicabanos, a maior parte está se formando pela PRI, em torno de $75 \%$.

Outra variável avaliada no questionário foi referente à religiosidade dos alunos ingressantes. Os alunos que se declaram católicos foram maioria, 66,5\%, seguidos por evangélicos, 10,4\%. Na Figura 20 é apresentada a contagem das declarações dos formandos associando a freqüência com que visitam o templo da religião que declaram seguir. 


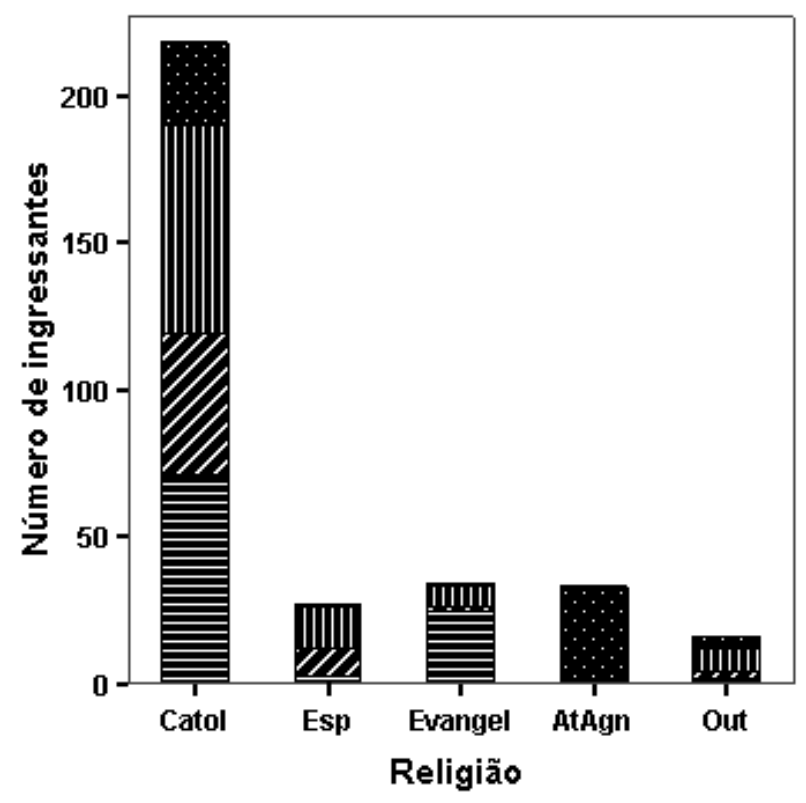

Freqüência de visita ao templo

$\therefore$ Nunca

IIII Raramente

7 De vez em quando

EFrequentemente

Diariamente

Figura 20 - Número de formandos por religião e freqüência ao templo religioso Fonte: Resultados da pesquisa.

O número de católicos que nunca freqüentam, ou então, raramente vão ao templo da religião é de magnitude significante, aproximadamente 45,4\%. Entre os evangélicos, em torno de 70,6\% vão freqüentemente ao templo de sua denominação. Na Figura 21 estão os percentuais dos questionários válidos levando em consideração o relacionamento entre as variáveis conhecer a influência da religião e freqüência de visita ao templo religioso. Do grupo dos 71 estudantes que gostariam de ser empresários, 64,8\% declararam-se católicos. No grupo dos 218 estudantes que se declararam católicos, a preferência é por desempenhar atividades como funcionários na iniciativa privada como funcionários, em torno de 49,5\%. O grupo que se declara ateu ou agnóstico é o com menor interesse em desempenhar atividades empresariais, em torno de 15,2\% dos pertencentes a este grupo gostariam de ser empresários. Entre ateus e agnósticos, 60,6\% gostariam de ocupar cargos públicos. 


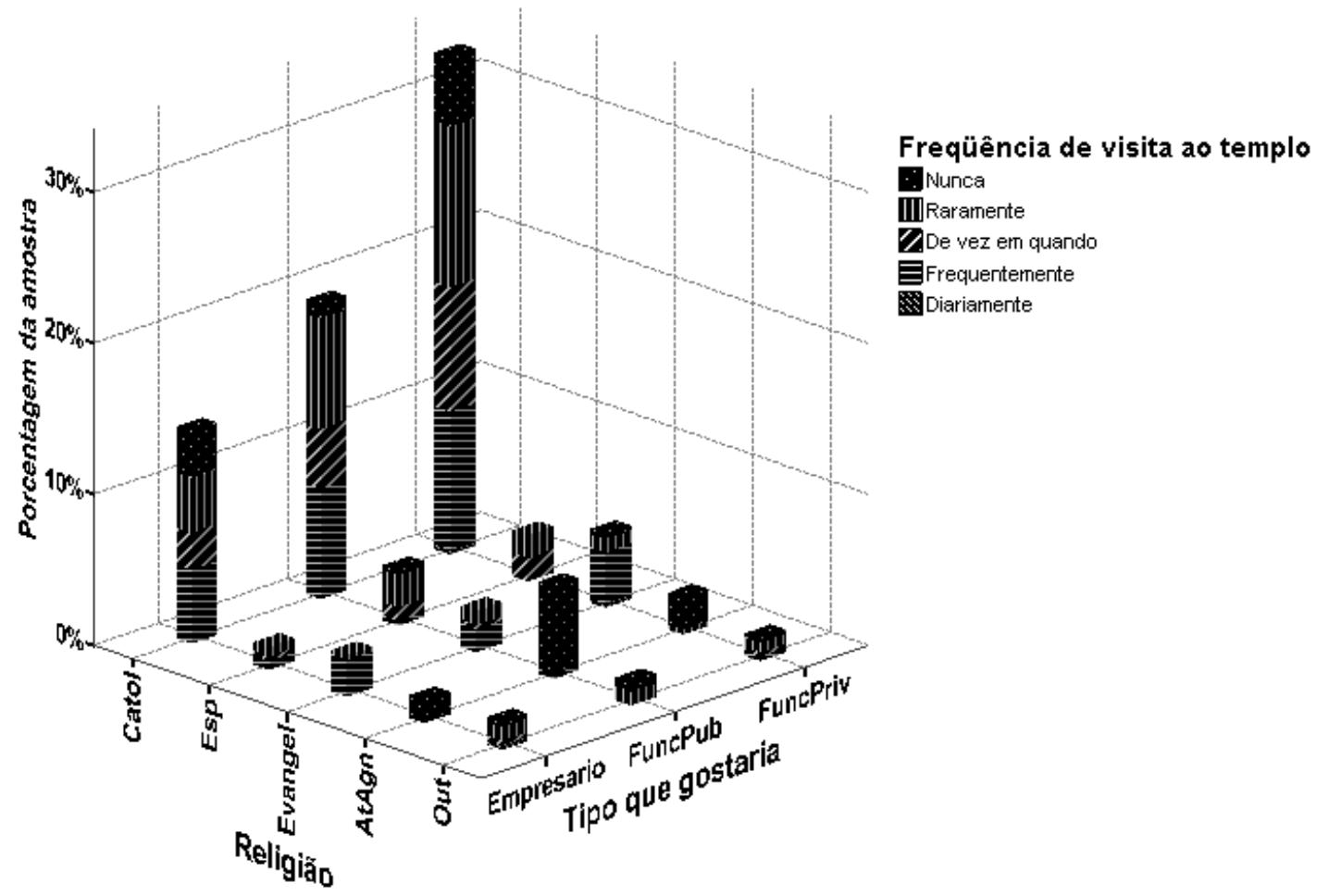

Figura 21 - Porcentagem dos questionários válidos por opção ocupacional e religião considerando-se a freqüência de visita ao templo da religião

Fonte: Resultados da pesquisa.

Analisando-se o grupo de alunos que acreditam que serão empresários verifica-se que os católicos continuam a ter maior crença de que serão empresários. Há pequenas variações dos percentuais com respeito ao gosto por ser empresário. Do grupo que acredita que será empresário, cerca de 69,0\% se declaram católicos. Comparando aos percentuais de gosto por atividades empresariais houve um aumento de 4,2 pontos percentuais. Dos estudantes que se declaram católicos, em torno de 42,7\% acreditam que atuarão como funcionários da iniciativa privada, 34,9\% que estarão no setor público e 22,5\% acreditam que serão empresários.

A variável idade é citada na literatura como importante na escolha ocupacional e foi investigada. Na Tabela 5 é apresentada a estatística descritiva desta variável para os questionários válidos. Cabe salientar que em três questionários os estudantes não declararam sua idade. 
Tabela 5 - Estatística descritiva para a variável idade

\begin{tabular}{lc}
\hline \multicolumn{1}{c}{ Estatísticas } & Idade \\
\hline Número de observações & 325 \\
Média & 19,43 \\
Mediana & 18 \\
Desvio Padrão & 2,966 \\
Assimetria & 2,174 \\
Curtose & 5,389 \\
Mínimo & 17 \\
Máximo & 35
\end{tabular}

Fonte: Resultados da pesquisa.

Os resultados da estatística descritiva indicam que há presença de outliers, dado o valor da média diferir da mediana. O valor de assimetria da variável idade sugere que a distribuição desta variável é assimétrica positiva. A inspeção do histograma com ajustamento de uma curva de distribuição normal é apresentada na Figura 22.

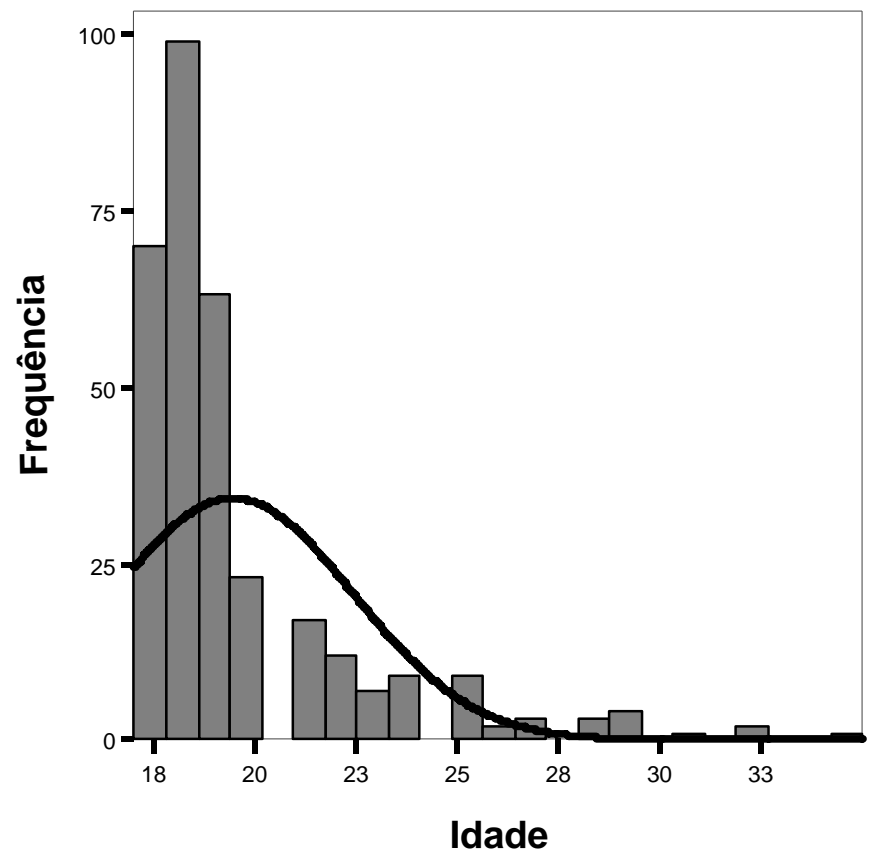

Figura 22 - Histograma com curva de ajustamento normal da variável idade 
Para a inspeção da presença de outliers foi plotado um gráfico boxplots. Este gráfico foi elaborado considerando-se as categorias de escolha ocupacional, conforme pode ser verificado na Figura 23.

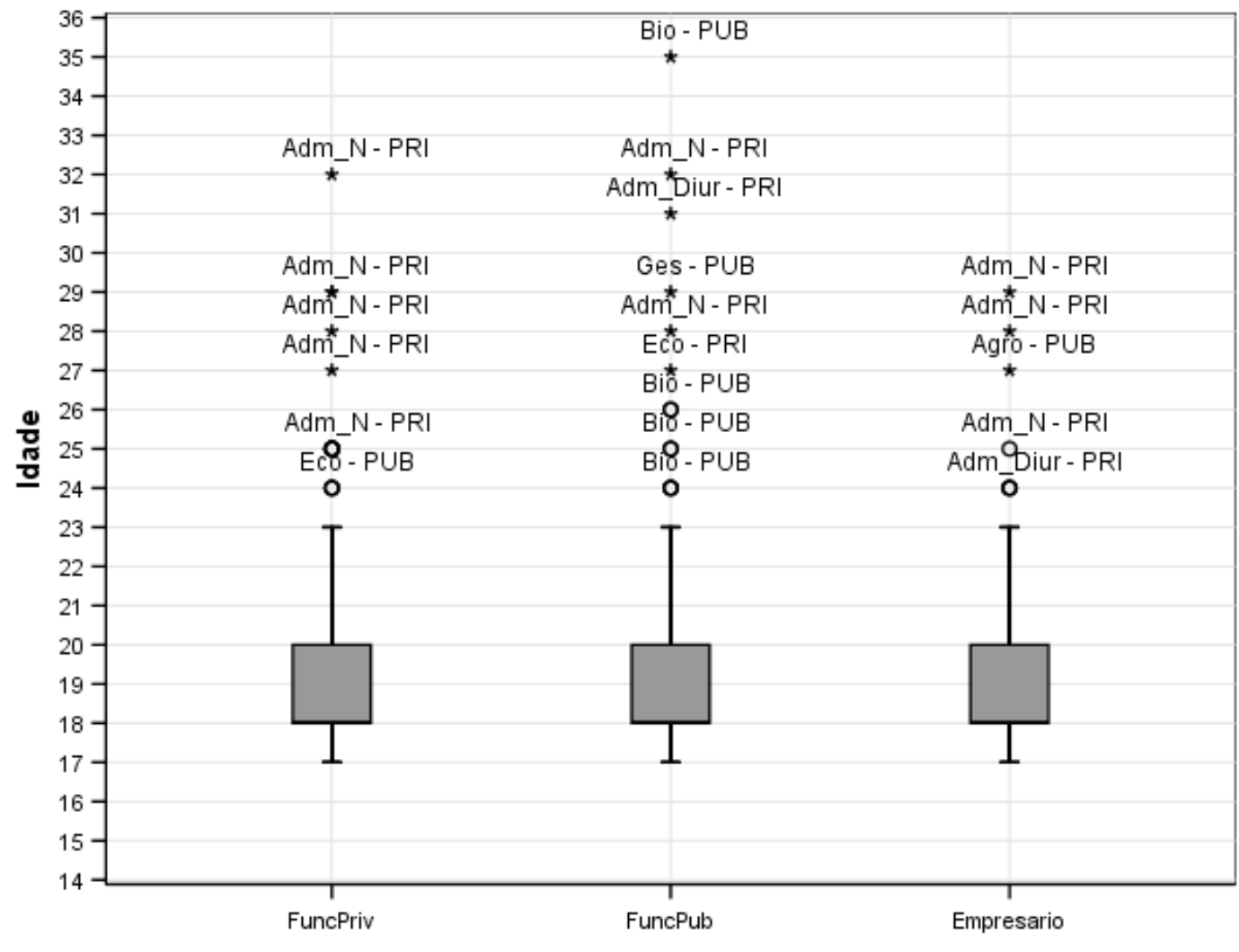

Tipo que gostaria

Figura 23 - Boxplots para avaliação da presença de outliers e valores extremos Fonte: Resultados da pesquisa.

Na Figura 23, os valores indicados por círculos referem-se à posição de outliers no banco de dados, enquanto por estrela indicam a localização de valores extremos. Os rótulos ao lado dos símbolos de outliers e valores extremos indicam o curso desta observação. Para todas as opções ocupacionais, idades superiores a 23 anos foram considerados como outliers. Pode-se inferir, a partir desta figura, que a mediana entre os grupos é igual, 19 anos; considerando-se a existência de outliers, a média não é uma medida apropriada.

Buscando a identificação do relacionamento entre estado civil e escolha ocupacional foi realizada a análise do perfil da amostra. No entanto, verifica-se predominância no grupo de 
solteiros, cerca de 97,0\% da amostra. Possivelmente tal resultado é decorrente do perfil de idade da amostra, que é composta predominantemente por jovens.

A variável renda familiar mensal também representa um fator socioeconômico relevante no processo de escolha ocupacional. A faixa de renda com maior número de declaração foi a de 5 a 10 salários mínimos, que representou 37,8\% da amostra. Em seqüência, tem-se a faixa entre 01 a 04 salários, com participação de 21,3\% e entre 11 a 15 salários mínimos, cerca de 21,0\% da amostra. É oportuno salientar que o questionamento sobre a renda pode apresentar distorções, já que as pessoas podem subestimar ou superestimar a declaração sobre os rendimentos. Na Figura 24 é apresentado um histograma da distribuição da amostra por nível de renda.

\section{Ajustamento da curva normal}
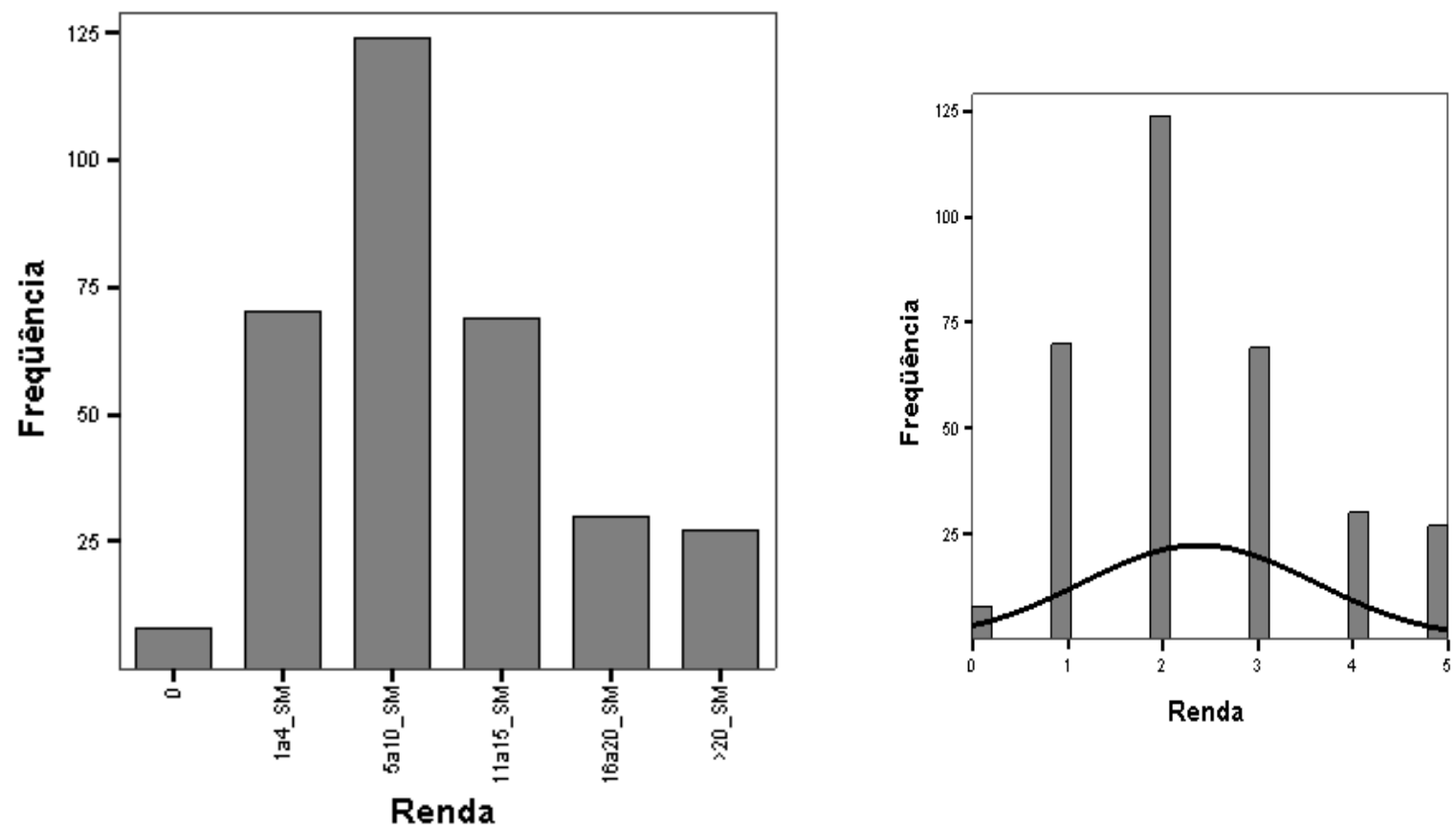

Figura 24 - Histograma com curva de ajustamento normal da variável renda Fonte: Resultado da pesquisa.

Na Figura 24 observa-se que em 8 observações constam renda igual a zero, estas são referentes a pessoas que não responderam a esta questão. A distribuição da variável renda aproxima-se de uma distribuição normal, há uma assimetria positiva. A participação das faixas de 
renda por preferência ocupacional controlada por curso é apresentada na Figura 25. Verifica-se que na faixa de renda familiar entre 16 a 20 salários mínimos, composta por 30 observações, há o maior percentual de gosto por atividade empresarial; em torno de 36,6\% destes estudantes gostariam de serem empresários. Na faixa de mais de 20 salários mínimos há empate entre o gosto por atividades empresariais e trabalhar na iniciativa privada como funcionário, 40,7\%. O gosto por atividades no setor público, dentre os com maior renda, é o menor quando comparado com as demais faixas de renda. No grupo de estudantes com renda familiar acima de 20 salários mínimos, em torno de 18,5\% apontaram que gostariam de ocupar cargos públicos, enquanto nas demais faixas o percentual foi de cerca de $35 \%$.

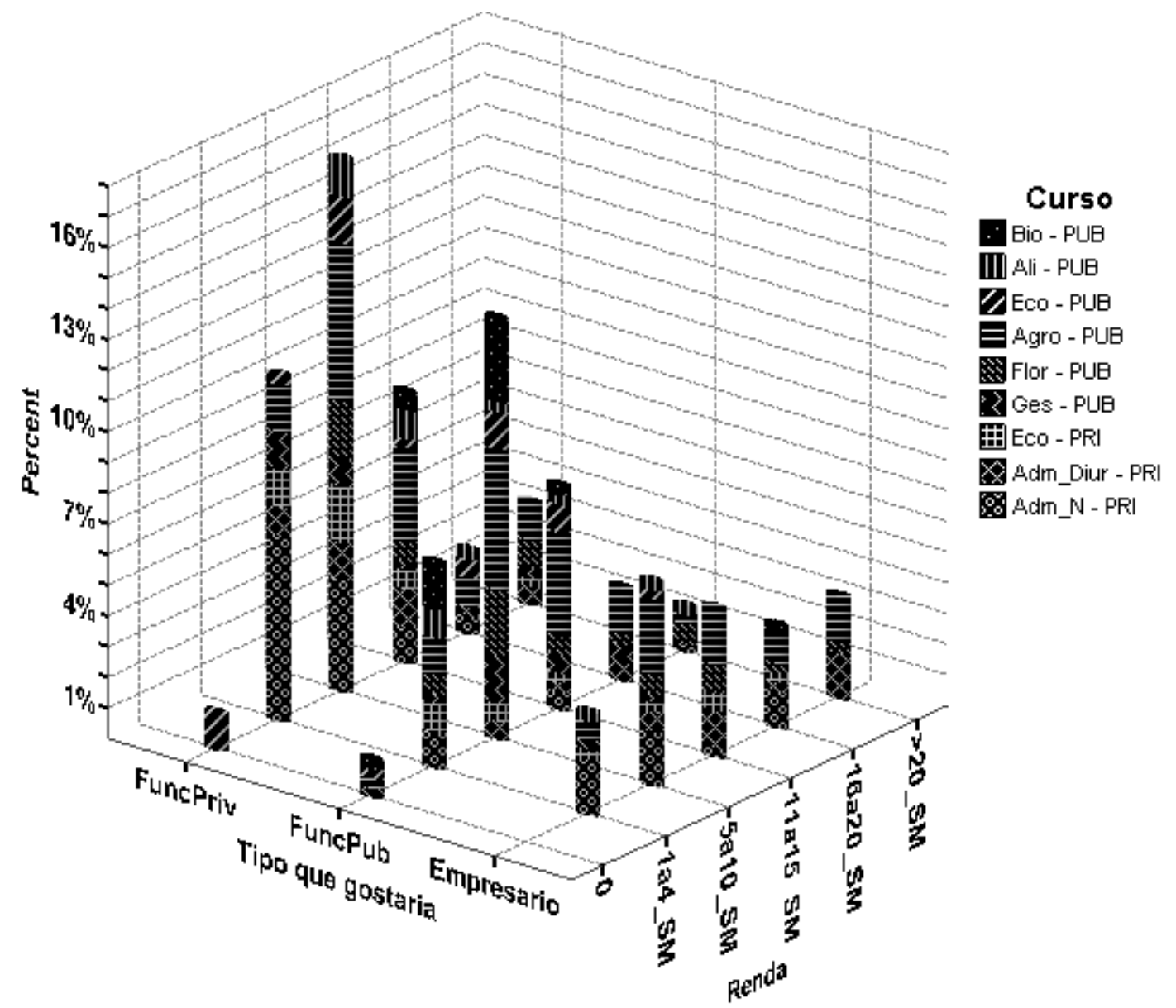

Figura 25 - Preferência ocupacional por faixa de renda familiar mensal, considerando-se o curso Fonte: Resultados da pesquisa. 
A faixa salarial de 5 a 10 salários mínimos, que representa a inserção de 37,8\% dos estudantes, é aquela com maior participação no grupo de empresários, cerca de 31,0\%. No entanto, 46,0\% das pessoas que declaram participar desta faixa salarial gostariam de ocupar posições em empresas nacionais ou multinacionais, como empregados. Estes resultados indicam que os estudantes de maior renda têm maior interesse em atividades empresariais, o que é assinalado na literatura.

Avaliando o relacionamento crença de atuar em uma ocupação e renda familiar mensal houve variações dentro de cada grupo de renda pelas preferências empresariais. O grupo de 16 a 20 salários mínimos e o grupo com mais de 20 salários mínimos reduziram o número de estudantes que acreditam que serão empresários. Os percentuais nestes dois grupos passaram a ser, respectivamente, $30,0 \%$ e $37,0 \%$. No grupo dos estudantes com renda familiar mensal maior de 20 salários mínimos foi significativo o aumento daqueles que acreditam que serão funcionários públicos. Os percentuais se aproximaram ao das demais faixas, em torno de 33,3\% dos alunos ingressantes deste grupo de renda declararam que acreditam que serão funcionários públicos. No grupo de faixa de renda de 1 a 4 salários mínimos houve comportamento semelhante de redução da participação em atividades empresariais. Os estudantes desta faixa de renda que acreditam que serão empresários são em torno de 12,9\%, o que implica em uma redução de 2,8 pontos percentuais, quando comparado aos percentuais de gosto por atividade empresarial declarados pelos ingressantes desta faixa de renda. Nas faixas de renda de 5 a 10 e 11 a 15 salários mínimos houve um aumento do número de estudantes que acreditam que serão empresários.

Com vistas a conhecer o perfil de risco dos estudantes e se há relacionamento entre a opção ocupacional e a atitude em relação ao risco foi acrescentada ao questionário uma questão que buscava avaliar o perfil de risco dos alunos. A questão indagava o valor que os estudantes pagariam por um bilhete de loteria que o estudante sortearia de uma urna com 100 bolas. As bolas são de duas cores, as brancas, cuja probabilidade de pegá-las é de 0,1\% e o prêmio seria de R\$ 25.000,00, e as bolas vermelhas, cuja probabilidade de pegá-las é 0,9\% e não há prêmio. Na amostra houve oito estudantes que não declararam o valor que pagariam. Na aplicação dos questionários aos estudantes foram identificados diversos problemas com respeito a esta questão. Os estudantes, ao responderem esta questão, esbarravam em questões morais, religiosas, alguns queriam elaborar cálculos mirabolantes, outros queriam buscar auxílio com colegas para 
responder, entre outros problemas. Com vistas a tentar melhorar este instrumento de avaliação de risco, foram incorporados aos questionários aplicados aos ingressantes dois itens que não existiam no questionário dos formandos. O primeiro é "não pago nada, pois por princípio eu não gosto de jogo”, e o segundo item é "não pago nada, pois tenho medo de arriscar”.

A análise das freqüências dos valores assinalados indicou que 28,0\% dos ingressantes declararam que não pagariam nada pelo bilhete, pois, por princípio, não gostam de jogo. $\mathrm{Na}$ Tabela 6 é apresentada a estatística descritiva destes estudantes que declararam que pagariam para participar da loteria, proposta no questionário.

Tabela 6 - Estatística descritiva da disposição a pagar por um bilhete de loteria

\begin{tabular}{lc}
\hline \multicolumn{1}{c}{ Estatísticas } & Idade \\
\hline Número de observações & 207 \\
Média & 95,94 \\
Mediana & 5,00 \\
Moda & 1,00 \\
Desvio Padrão & 735,76 \\
Assimetria & 12,30 \\
Curtose & 162,18 \\
Mínimo & 0,50 \\
Máximo & $10.000,00$ \\
\hline
\end{tabular}

Fonte: Resultados da pesquisa.

Os resultados da estatística descritiva indicam que há uma grande amplitude dos dados. A média não é uma boa medida da variável. O valor mais freqüente de resposta foi o de $\mathrm{R} \$ 1,00$, cerca de 14,0\% dos estudantes responderam que pagariam este valor; em seqüência, tem-se o valor de $\mathrm{R} \$ 10,00$, com o percentual de $12,5 \%$ e $\mathrm{R} \$ 5,00$, com 9,1\%. O valor de $\mathrm{R} \$ 1,00$ deve-se ao fato de os estudantes associaram a loteria proposta no questionário com as loterias oficiais, onde o bilhete custava este valor. Na Figura 26 são apresentados os valores respondidos pelos ingressantes; observa-se que o valor 0,01 e 0,02 referem-se, respectivamente, aos itens "não pago, pois por princípio não gosto de jogo" e "não pago, pois tenho medo de arriscar”. 


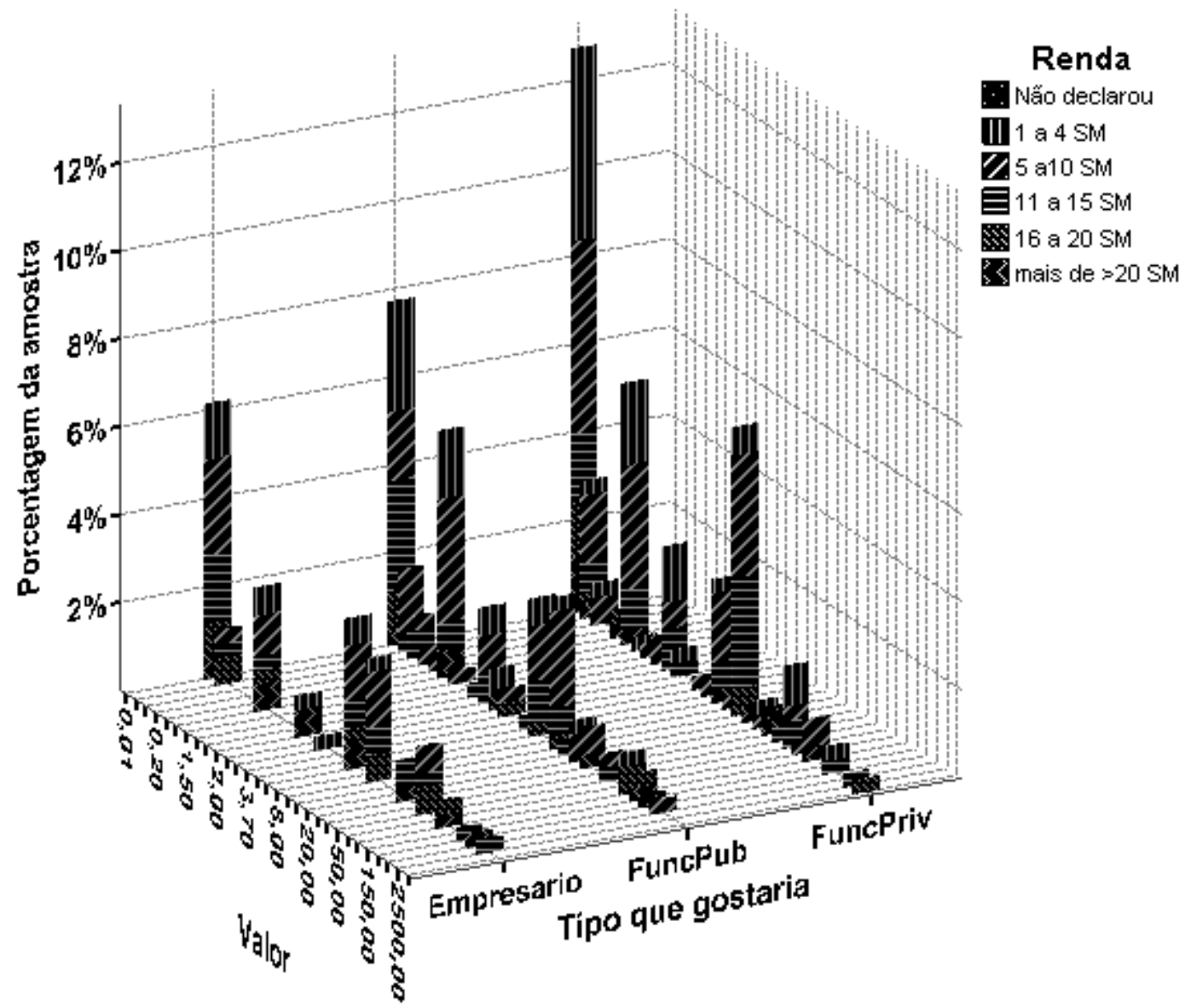

Figura 26 - Disposição dos alunos ingressantes a pagar por um bilhete de loteria levando em conta o gosto por uma preferência ocupacional, considerando-se a renda familiar mensal

Fonte: Resultado da pesquisa

Pode-se observar que dentre aqueles que gostariam de ocupar posições empresariais a maior parte não pagaria pelo bilhete em razão de seus princípios. Do grupo formado por aqueles que gostariam de ser empresários, em torno de 34,3\% não pagariam pelos bilhetes; destes, 28,6\% em razão de seus princípios.

O confronto entre a disposição a pagar pelo bilhete e a renda familiar permite a avaliação do comportamento de risco considerando-se a situação financeira familiar. Na Figura 27 é apresentada a distribuição da disposição a pagar declarada pelos formandos, por faixa de renda. 

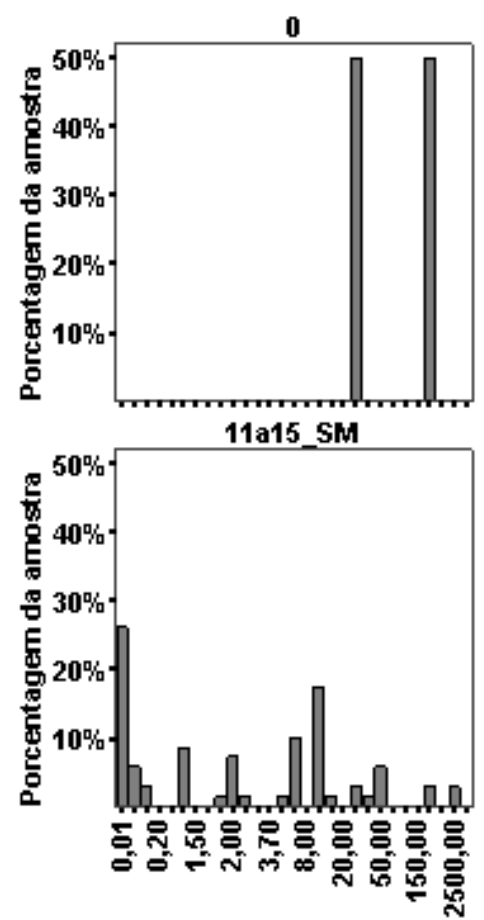

Valor

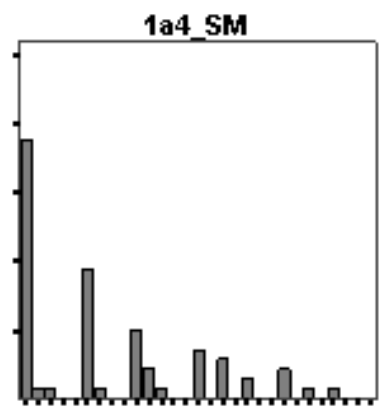

16a20_SM

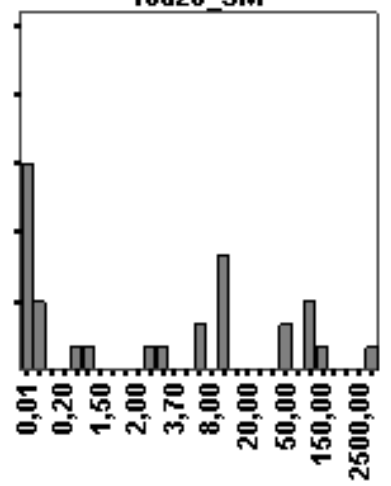

Valor

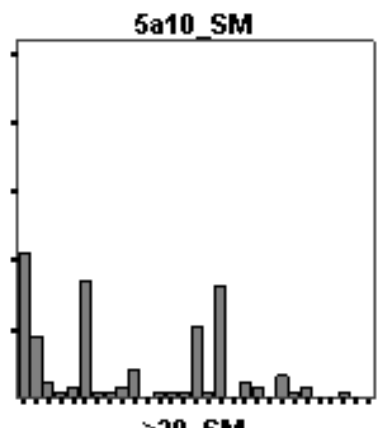

$>20 \_$SM

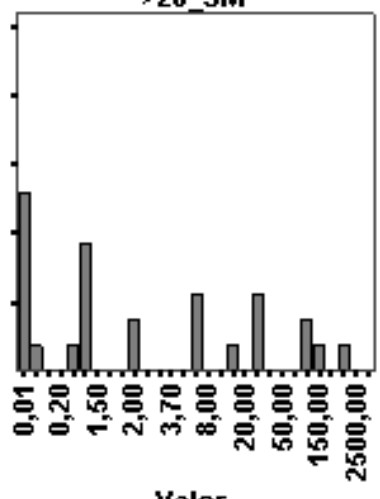

Valor

Figura 27 - Valores pagos pelos formandos por um bilhete de loteria considerando-se a renda familiar mensal

Fonte: Resultado da pesquisa.

Na literatura é discutida a relação entre renda e risco, explicando que indivíduos com maior renda estariam mais propensos a aceitar maiores riscos. A verificação deste comportamento não foi encontrada na amostra. Percebe-se que na faixa de rendimentos mais elevados não há propensão a pagar mais pelos bilhetes.

O questionário aplicado é composto também por perguntas que visavam identificar quais fatores influenciavam na escolha ocupacional. Para estas perguntas foram realizados testes não paramétricos. Os testes aplicados foram: teste de normalidade de Kolmogorov - Smirnov, teste de Friedman, teste de Wilconxon e teste de Krustal-Wallis.

A condução destes testes tem como objetivo identificar quais dos fatores considerados na literatura são de relevância na escolha ocupacional da amostra do estudo, e para cada perfil ocupacional considerado qual fator é importante. 
Os primeiros fatores discutidos são referentes à questão 12, a qual inquiria os estudantes com respeito aos fatores que influenciavam na escolha pela atividade desejada. A fim de verificar se as variáveis seguem uma distribuição normal foi aplicado o teste de normalidade de Kolmogorov - Smirnov. Os resultados deste teste indicarão se a aplicação de teste não paramétrico é indicada. Na Tabela 7 estão os resultados deste teste.

Tabela 7 - Teste de Normalidade de Kolmogorov - Smirnov para os fatores que impedem com que as preferências ocupacionais dos ingressantes não correspondam às posições que gostariam de ocupar

\begin{tabular}{|c|c|c|c|c|}
\hline \multirow{2}{*}{ Fatores } & \multicolumn{2}{|c|}{ Parâmetros normais } & \multirow{2}{*}{$\begin{array}{l}\text { Teste de } \\
\text { Kolmogorov- } \\
\text { Smirnov Z }\end{array}$} & \multirow{2}{*}{$\begin{array}{l}\text { P-valor do teste de } \\
\text { Kolmogorov- } \\
\text { Smirnov Z }\end{array}$} \\
\hline & Média & $\begin{array}{l}\text { Desvio } \\
\text { Padrão }\end{array}$ & & \\
\hline Acesso a financiamento & 4,64 & 2,860 & 2,767 & 0,000 \\
\hline Orientação familiar & 3,05 & 3,304 & 3,813 & 0,000 \\
\hline Treinamento formal deficiente & 3,91 & 3,416 & 2,844 & 0,000 \\
\hline Política econômica do país & 6,02 & 2,826 & 2,349 & 0,000 \\
\hline Questões institucionais do país & 5,59 & 2,771 & 2,329 & 0,000 \\
\hline $\begin{array}{l}\text { Acredita que não tem chances de } \\
\text { sucesso fazendo o que gostaria }\end{array}$ & 2,12 & 2,930 & 4,790 & 0,000 \\
\hline
\end{tabular}

Fonte: Resultados da pesquisa.

Os valores calculados de média e desvio padrão devem ser utilizados com cautela, dado que o teste de normalidade de Kolmogorov - Smirnov, com nível de significância de 1\%, indicou um ajustamento à curva normal estatisticamente não significativo. Dado este resultado, procedeu-se à aplicação de teste não paramétrico para analisar estes fatores.

Primeiramente, aplicou-se o teste de Friedman a fim de se verificar se alguns dos fatores listados na Tabela 7 apresentam médias ranqueadas diferentes, o que implica que os fatores não influenciam na escolha ocupacional de forma semelhante. O resultado deste teste para os fatores que impedem que a crença seja diferente do que os ingressantes gostariam de desempenhar indica que esses fatores não afetam de maneira análoga. $O$ valor do teste de $\chi^{2}{ }_{c}=309,79$, indica, ao 
nível de significância de 1\%, que ao menos um dos fatores considerados impede de maneira diferente que o gosto por desempenhar um perfil profissional corresponda à crença de que ocuparão o perfil ocupacional desejado.

O resultado apresentado pelo teste de Friedman não possibilita a identificação de quais fatores diferem uns dos outros para influenciar a preferência ocupacional dos alunos. Desta forma, não é possível identificar quais fatores estão relacionados ao gosto e quais estão relacionados à crença. Desta forma, a aplicação do teste de Wilcoxon permitirá identificar comparando-se 2 a 2 fatores quais conjuntos apresentam diferença de média.

Os resultados obtidos pelo teste de Wilcoxom são apresentados na Tabela 8. Verifica-se que a maior parte dos pares analisados apresentou diferença da média estatisticamente significativa.

Tabela 8 - Matriz de resultados do teste de Wilcoxon para a diferença entre os fatores que impedem que a crença não corresponda à preferência ocupacional que os ingressantes gostariam de atuar

\begin{tabular}{|c|c|c|c|c|c|c|c|}
\hline & $\begin{array}{l}\text { Recursos } \\
\text { financeiros } \\
\text { próprios }\end{array}$ & $\begin{array}{c}\text { Acesso a } \\
\text { financia- } \\
\text { mento }\end{array}$ & $\begin{array}{c}\text { Orienta-ção } \\
\text { familiar }\end{array}$ & $\begin{array}{l}\text { Treina- } \\
\text { mento } \\
\text { formal } \\
\text { deficiente }\end{array}$ & $\begin{array}{l}\text { Política } \\
\text { econômica } \\
\text { do país }\end{array}$ & $\begin{array}{c}\text { Questões } \\
\text { institucionais } \\
\text { do país }\end{array}$ & $\begin{array}{l}\text { Possibili- } \\
\text { dade de } \\
\text { insucesso na } \\
\text { atividade }\end{array}$ \\
\hline $\begin{array}{l}\text { Recursos } \\
\text { Financeiros } \\
\text { Próprios }\end{array}$ & & $-5,966^{\mathrm{a}}$ & $-10,452^{a}$ & $-7,251^{\mathrm{a}}$ & $-0,978^{\mathrm{ns}}$ & $-1,250^{\mathrm{ns}}$ & $-11,938^{\mathrm{a}}$ \\
\hline $\begin{array}{l}\text { Acesso a } \\
\text { Financiamento }\end{array}$ & & & $-6,704^{\mathrm{a}}$ & $-3,089^{\mathrm{a}}$ & $-6,129^{a}$ & $-4,332^{a}$ & $-9,991^{\mathrm{a}}$ \\
\hline $\begin{array}{l}\text { Orientação } \\
\text { Familiar }\end{array}$ & & & & $-3,790^{\mathrm{a}}$ & $-10,560^{a}$ & $-9,507^{a}$ & $-3,910^{\mathrm{a}}$ \\
\hline $\begin{array}{l}\text { Treinamento } \\
\text { formal } \\
\text { deficiente }\end{array}$ & & & & & $-8,363^{\mathrm{a}}$ & $-7,034^{a}$ & $-6,882^{\mathrm{a}}$ \\
\hline $\begin{array}{l}\text { Política } \\
\text { econômica do } \\
\text { país }\end{array}$ & & & & & & $-3,367^{a}$ & $-12,225^{a}$ \\
\hline $\begin{array}{l}\text { Questões } \\
\text { Institucionais } \\
\text { do país } \\
\text { Possibilidade } \\
\text { de insucesso } \\
\text { na atividade }\end{array}$ & & & & & & & $-11,446^{\mathrm{a}}$ \\
\hline $\begin{array}{l}\text { a - significati } \\
\text { ns - não sign }\end{array}$ & $\begin{array}{l}\text { o a } 1 \% \\
\text { icativo }\end{array}$ & & & & & & \\
\hline
\end{tabular}


Contata-se que os dois pares de variáveis apresentaram média igual de influência, o primeiro é política econômica do país e recursos financeiros próprios; o segundo é questões institucionais e recursos financeiros próprios. Possivelmente tal resultado seja devido ao fato de os ingressantes considerarem que essas variáveis, política econômica do país e questões institucionais do país, quando relacionadas a recursos financeiros próprios, estejam correlacionadas.

A fim de se verificar se há diferenças entre os perfis ocupacionais quanto aos fatores que dificultam com que os ingressantes atuem no que desejam como opção ocupacional foi utilizado o teste de Kruskal-Wallis. Os resultados são apresentados na Tabela 9.

Tabela 9 - Teste de Kruskal - Wallis para identificar a influência dos fatores que impedem com que crenças coincidam com a opção que gostaria por perfil ocupacional

\begin{tabular}{|c|c|}
\hline Fatores & Valor do teste \\
\hline Recursos financeiros próprios & $2,393^{\text {ns }}$ \\
\hline Acesso a financiamento & $0,608^{\mathrm{ns}}$ \\
\hline Orientação familiar & $7,527^{b}$ \\
\hline Treinamento formal deficiente & $3,341^{\mathrm{ns}}$ \\
\hline Política econômica do país & $4,288^{\mathrm{ns}}$ \\
\hline Questões institucionais do país & $2,832^{\mathrm{ns}}$ \\
\hline Acredita que não tem chances de sucesso fazendo o que gostaria & $5,582^{c}$ \\
\hline
\end{tabular}

b - significativo a $5 \%$

c - significativo a $10 \%$

ns - não significativo

Fonte: Resultados da pesquisa.

Os resultados do teste indicam que entre os perfis considerados há diferença estatisticamente significativa entre as médias para as variáveis orientação familiar e autoconfiança no sucesso. Desta forma, pode-se inferir que tanto para funcionários da iniciativa privada quanto para funcionários públicos ou para empresários a percepção da influência destes fatores, que impedem que o gosto e a intenção sejam divergentes, difere considerando-se o perfil ocupacional que gostariam de desempenhar. Entretanto, não há como afirmar em qual destes grupos a média é maior para estas variáveis, é necessário verificar em qual perfil há maior impacto destes fatores. 
A próxima questão a ser avaliada relacionava-se aos fatores que influenciam na preferência ocupacional dos indivíduos. Nesta questão, várias hipóteses discutidas na literatura são testadas a fim de se verificar se aqueles com perfil de funcionário diferem ou não daqueles com perfil de empresário.

O teste de normalidade de Kolmogorov - Smirnov é apresentado para os fatores considerados na Tabela 10. Este teste visa analisar a adequação da aplicação dos testes não paramétricos para a análise dos fatores que influenciam na escolha da posição que os ingressantes gostariam de atuar.

Tabela 10 - Teste de Normalidade de Kolmogorov - Smirnov para os fatores que influenciam nas preferências ocupacionais dos ingressantes

\begin{tabular}{|c|c|c|c|c|}
\hline \multirow[b]{2}{*}{ Fatores } & \multicolumn{2}{|c|}{$\begin{array}{l}\text { Parâmetros } \\
\text { normais (a) }\end{array}$} & \multirow{2}{*}{$\begin{array}{l}\text { Teste de } \\
\text { Kolmogorov- } \\
\text { Smirnov Z }\end{array}$} & \multirow{2}{*}{$\begin{array}{c}\text { P-valor do } \\
\text { teste de } \\
\text { Kolmogorov- } \\
\text { Smirnov Z }\end{array}$} \\
\hline & Média & $\begin{array}{l}\text { Desvio } \\
\text { padrão }\end{array}$ & & \\
\hline Maior remuneração da atividade & 7,13 & 2,677 & 2,794 & 0,000 \\
\hline Menos horas trabalhadas & 4,38 & 3,146 & 1,890 & 0,002 \\
\hline Maior estabilidade da atividade & 7,20 & 2,794 & 3,771 & 0,000 \\
\hline Maior status social & 4,45 & 3,312 & 2,109 & 0,000 \\
\hline $\begin{array}{l}\text { Mais prazer proporcionado pelo } \\
\text { cotidiano da atividade }\end{array}$ & 8,68 & 1,980 & 4,711 & 0,000 \\
\hline Pelo incentivo da família & 5,17 & 3,409 & 2,115 & 0,000 \\
\hline Pela orientação do curso universitário & 6,46 & 2,960 & 2,756 & 0,000 \\
\hline
\end{tabular}

a - Distribuição testada é normal.

Fonte: Resultados da pesquisa.

A análise do teste de normalidade indica que os aspectos considerados como influenciadores da escolha por determinados tipo de ocupação não seguem uma distribuição normal. Como conseqüência, os testes não paramétricos são apropriados para a análise deste fator. Assim, é aplicado o teste de Friedman para a análise deste aspecto. O resultado deste teste, $\chi_{c}^{2}=550,840$, indica que existe diferença entre as médias dos fatores com nível de significância de $1 \%$. 
A partir do resultado do teste de Friedman, do qual se conclui que os fatores considerados como importantes na decisão de escolha ocupacional não têm impacto igual na escolha, aplicouse o teste de Wilcoxon. Apesar de não se concluir qual dos dois fatores avaliados tem maior média, o conhecimento de que as médias em pares são diferentes já é útil. Na Tabela 11 são apresentados os resultados deste teste.

Tabela 11 - Matriz de resultados do teste de Wilcoxon para a diferença entre os fatores que influenciam na decisão de escolha ocupacional

\begin{tabular}{|c|c|c|c|c|c|c|c|}
\hline & $\begin{array}{c}\text { Maior } \\
\text { remuneração } \\
\text { da atividade }\end{array}$ & $\begin{array}{c}\text { Menos } \\
\text { horas } \\
\text { trabalhadas }\end{array}$ & $\begin{array}{c}\text { Maior } \\
\text { estabilidade } \\
\text { da atividade }\end{array}$ & $\begin{array}{l}\text { Maior } \\
\text { status } \\
\text { social }\end{array}$ & $\begin{array}{l}\text { Prazer } \\
\text { em atuar }\end{array}$ & $\begin{array}{l}\text { Incentivo } \\
\text { da família }\end{array}$ & $\begin{array}{c}\text { Orientação do } \\
\text { curso } \\
\text { universitário }\end{array}$ \\
\hline $\begin{array}{l}\text { Maior } \\
\text { remuneração } \\
\text { da atividade }\end{array}$ & & $-12,408^{\mathrm{a}}$ & $-1,178^{\mathrm{ns}}$ & $-11,212^{\mathrm{a}}$ & $-7,808^{a}$ & $-8,208^{a}$ & $-3,317^{\mathrm{a}}$ \\
\hline $\begin{array}{l}\text { Menos horas } \\
\text { trabalhadas }\end{array}$ & & & $-11,938^{a}$ & $-0,793^{\text {ns }}$ & $-13,462^{a}$ & $-3,388^{a}$ & $-8,542^{a}$ \\
\hline $\begin{array}{l}\text { Maior } \\
\text { estabilidade da } \\
\text { atividade }\end{array}$ & & & & $-11,055^{\mathrm{a}}$ & $-7,654^{\mathrm{a}}$ & $-8,874^{a}$ & $-4,255^{a}$ \\
\hline $\begin{array}{l}\text { Maior } \\
\text { status social }\end{array}$ & & & & & $-13,087^{\mathrm{a}}$ & $-3,033^{a}$ & $-8,402^{\mathrm{a}}$ \\
\hline $\begin{array}{l}\text { Prazer em } \\
\text { atuar }\end{array}$ & & & & & & $-12,429^{a}$ & $-10,329^{a}$ \\
\hline $\begin{array}{l}\text { Incentivo da } \\
\text { família } \\
\text { Orientação do } \\
\text { curso } \\
\text { universitário }\end{array}$ & & & & & & & $-7,176^{\mathrm{a}}$ \\
\hline
\end{tabular}

A análise do teste de Wilcoxon permite concluir que a maior parte dos relacionamentos entre duas variáveis analisadas é estatisticamente significativa a 1\%. Como pares de variáveis que não apresentaram médias diferentes têm-se maior estabilidade versus maior remuneração, maior status social versus menos horas trabalhadas. A não significância constatada pode ser resultado do tamanho da amostra, ou então, de questões culturais.

Com o objetivo de verificar se há diferenças entre as médias dos fatores considerando-se os diferentes perfis ocupacionais aplicou-se o teste de Kruskal - Wallis. O teste é aplicado tanto para o gosto por uma ocupação quanto para a intenção de atuar em uma atividade. Os resultados 
do teste para as variáveis que influenciam a preferência pelas atividades que gostariam de ocupar são apresentados na Tabela 12.

Tabela 12 - Teste de Kruskal - Wallis para identificar a influência dos fatores na decisão de escolha ocupacional

\begin{tabular}{lcc}
\hline \multirow{2}{*}{ Fatores } & \multicolumn{2}{c}{ Valor do teste } \\
\cline { 2 - 3 } & Gosto & Acredita \\
\hline Maior remuneração da atividade & $33,732^{\mathrm{a}}$ & $27,719^{\mathrm{a}}$ \\
Menos horas trabalhadas & $10,228^{\mathrm{a}}$ & $7,433^{\mathrm{b}}$ \\
Maior estabilidade da atividade & $13,362^{\mathrm{a}}$ & $10,984^{\mathrm{a}}$ \\
Maior status social & $27,698^{\mathrm{a}}$ & $20,070^{\mathrm{a}}$ \\
Mais prazer proporcionado pelo cotidiano da atividade & $17,719^{\mathrm{a}}$ & $14,445^{\mathrm{a}}$ \\
Pelo incentivo da família & $12,686^{\mathrm{a}}$ & $17,722^{\mathrm{a}}$ \\
Pela orientação do curso Universitário & $5,434^{\mathrm{c}}$ & $9,852^{\mathrm{a}}$ \\
\hline
\end{tabular}

a - significativo a $1 \%$

b - significativo a $5 \%$

c - significativo a $10 \%$

ns - não significativo

Fonte: Resultado da pesquisa.

Os resultados do teste indicam que para todas as variáveis analisadas há diferença estatisticamente significativa para a média atribuída pelos ingressantes considerando-se o tipo ocupacional, tanto pelo gosto quanto pela crença por um perfil ocupacional. As diferenças são estatisticamente significativas a 1\%, com exceção da variável menos horas trabalhadas, referindose à análise do perfil ocupacional que os estudantes acreditam que desempenharão.

O teste de normalidade de Kolmogorov - Smirnov para as variáveis da questão que buscava identificar a influência das pessoas do círculo de convivência dos estudantes no seu gosto e na sua intenção de atuar em uma atividade é apresentado na Tabela 13. Os resultados indicam que as variáveis não seguem distribuição normal. 
Tabela 13 - Teste de Normalidade de Kolmogorov - Smirnov para testar a distribuição do grau de influência das pessoas do círculo dos ingressantes na decisão de escolha ocupacional

\begin{tabular}{|c|c|c|c|c|}
\hline \multirow[b]{2}{*}{ Fatores } & \multicolumn{2}{|c|}{ Parâmetros normais(a) } & \multirow{2}{*}{$\begin{array}{c}\text { Teste de } \\
\text { Kolmogorov- } \\
\text { Smirnov Z }\end{array}$} & \multirow{2}{*}{$\begin{array}{l}\text { P-valor do teste } \\
\text { de Kolmogorov- } \\
\text { Smirnov Z }\end{array}$} \\
\hline & Média & $\begin{array}{l}\text { Desvio } \\
\text { padrão }\end{array}$ & & \\
\hline Pai & 4,43 & 3,606 & 2,699 & 0,000 \\
\hline Mãe & 4,92 & 3,504 & 1,922 & 0,001 \\
\hline Irmãos & 2,83 & 3,227 & 4,477 & 0,000 \\
\hline Tios & 2,39 & 3,008 & 4,531 & 0,000 \\
\hline Avós & 1,97 & 2,855 & 5,475 & 0,000 \\
\hline Amigos ou colegas & 3,37 & 3,052 & 3,086 & 0,000 \\
\hline Professores & 4,59 & 3,448 & 2,668 & 0,000 \\
\hline
\end{tabular}

Fonte: Resultado da pesquisa.

A aplicação dos testes não paramétricos é apropriada, em razão de se aceitar que todas as variáveis analisadas nesta questão não seguem distribuição normal, com nível de significância de 1\%. Desta forma, devido aos resultados do teste de normalidade de Kolmogorov - Smirnov aplicou-se o teste de Friedman. O valor deste teste, $\chi^{2}{ }_{c}=348,568568$ indica, no nível de significância de 1\%, que ao menos um dos membros do círculo dos formandos afeta de maneira diferente na sua decisão de escolha ocupacional.

A existência de diferença entre as médias atribuídas pelos formandos ao grau de influência das pessoas de seu círculo social justifica a averiguação da existência de diferença entre as médias por pares de variáveis deste fator. O teste de Wilcoxon é apresentado na Tabela 14. 
Tabela 14 - Matriz de resultados do teste de Wilcoxon entre o grau de influência das pessoas do círculo dos ingressantes na decisão de escolha ocupacional

\begin{tabular}{|c|c|c|c|c|c|c|c|}
\hline & Pai & Mãe & Irmãos & Tios & Avós & $\begin{array}{l}\text { Amigos ou } \\
\text { colegas }\end{array}$ & Professores \\
\hline Pai & & $-2,414^{\mathrm{ns}}$ & $-6,752^{a}$ & $-8,603^{a}$ & $-9,987^{\mathrm{a}}$ & $-4,514^{\mathrm{a}}$ & $-0,635^{\mathrm{ns}}$ \\
\hline Mãe & & & $-8,742^{a}$ & $-9,853^{a}$ & $-11,515^{\mathrm{a}}$ & $-6,386^{a}$ & $-1,291^{\mathrm{ns}}$ \\
\hline Irmãos & & & & $-2,422^{a}$ & $-4,519^{a}$ & $-2,503^{a}$ & $-7,422^{\mathrm{a}}$ \\
\hline Tios & & & & & $-3,211^{a}$ & $-5,242^{a}$ & $-9,177^{\mathrm{a}}$ \\
\hline Avós & & & & & & $-6,797^{\mathrm{a}}$ & $-10,263^{a}$ \\
\hline Amigos ou colegas & & & & & & & $-6,280^{\mathrm{a}}$ \\
\hline Professores & & & & & & & \\
\hline
\end{tabular}

a - significativo a $1 \%$

ns - não significativo

Fonte: Resultado da pesquisa.

Observa-se que os pares de variáveis: pai e mãe, professores e pai, professores e mãe não apresentam diferença de média. Assim, não se pode concluir, por exemplo, que a mãe tenha uma influência diferente do pai no processo de escolha ocupacional. Os demais relacionamentos analisados revelaram diferenças estatisticamente significativas ao nível de $1 \%$.

A investigação da existência de diferença entre o efeito médio das pessoas do círculo dos ingressantes na opção ocupacional, considerando-se o gosto e a crença em desempenhar cargo de funcionário ou empresário, é apresentada na Tabela 15. 
Tabela 15 - Teste de Kruskal - Wallis para identificar a influência dos fatores que influenciam na decisão de escolha ocupacional

\begin{tabular}{lcc}
\hline \multirow{2}{*}{ Fatores } & \multicolumn{2}{c}{ Valor do teste } \\
\cline { 2 - 3 } & Gosto & Acredita \\
\hline Pai & $7,750^{\mathrm{b}}$ & $13,642^{\mathrm{a}}$ \\
Mãe & $7,744^{\mathrm{b}}$ & $3,996^{\mathrm{ns}}$ \\
Irmãos & $0,938^{\mathrm{ns}}$ & $0,029^{\mathrm{ns}}$ \\
Tios & $2,390^{\mathrm{ns}}$ & $3,090^{\mathrm{ns}}$ \\
Avós & $9,399^{\mathrm{a}}$ & $11,901^{\mathrm{a}}$ \\
Amigos ou colegas & $0,491^{\mathrm{ns}}$ & $0,220^{\mathrm{ns}}$ \\
Professores & $2,469^{\mathrm{ns}}$ & $0,793^{\mathrm{ns}}$ \\
\hline
\end{tabular}

a - significativo a $1 \%$

b - significativo a $5 \%$

ns - não significativo

Fonte: Resultado da pesquisa.

Observa-se pelo resultado do teste de Kruskal - Wallis que algumas das pessoas consideradas como possíveis formadoras de opinião e, conseqüentemente, influenciadoras na decisão de escolha da atividade profissional, têm maior participação média no gosto e na crença de escolha ocupacional. Com relação ao gosto, pai, mãe e avós têm, em média, maior influência. Com relação à crença do que estarão fazendo no futuro, pai e avós têm maiores influência. Em nenhum dos aspectos, o gosto e a intenção, os professores tiveram influência na decisão de escolha dos estudantes.

O último fator a ser analisado será o que visa identificar aspectos que os ingressantes esperam com relação às escolas PUB - ESALQ e PRI, para que seja possível atuar no que gostariam. Na Tabela 16 estão as variáveis escolhidas, bem como suas estatísticas descritivas e resultado do teste de Kolmogorov - Smirnov. 
Tabela 16 - Teste de Normalidade de Kolmogorov - Smirnov para fatores que os ingressantes consideram importantes no curso universitário para auxiliá-los no desempenho profissional

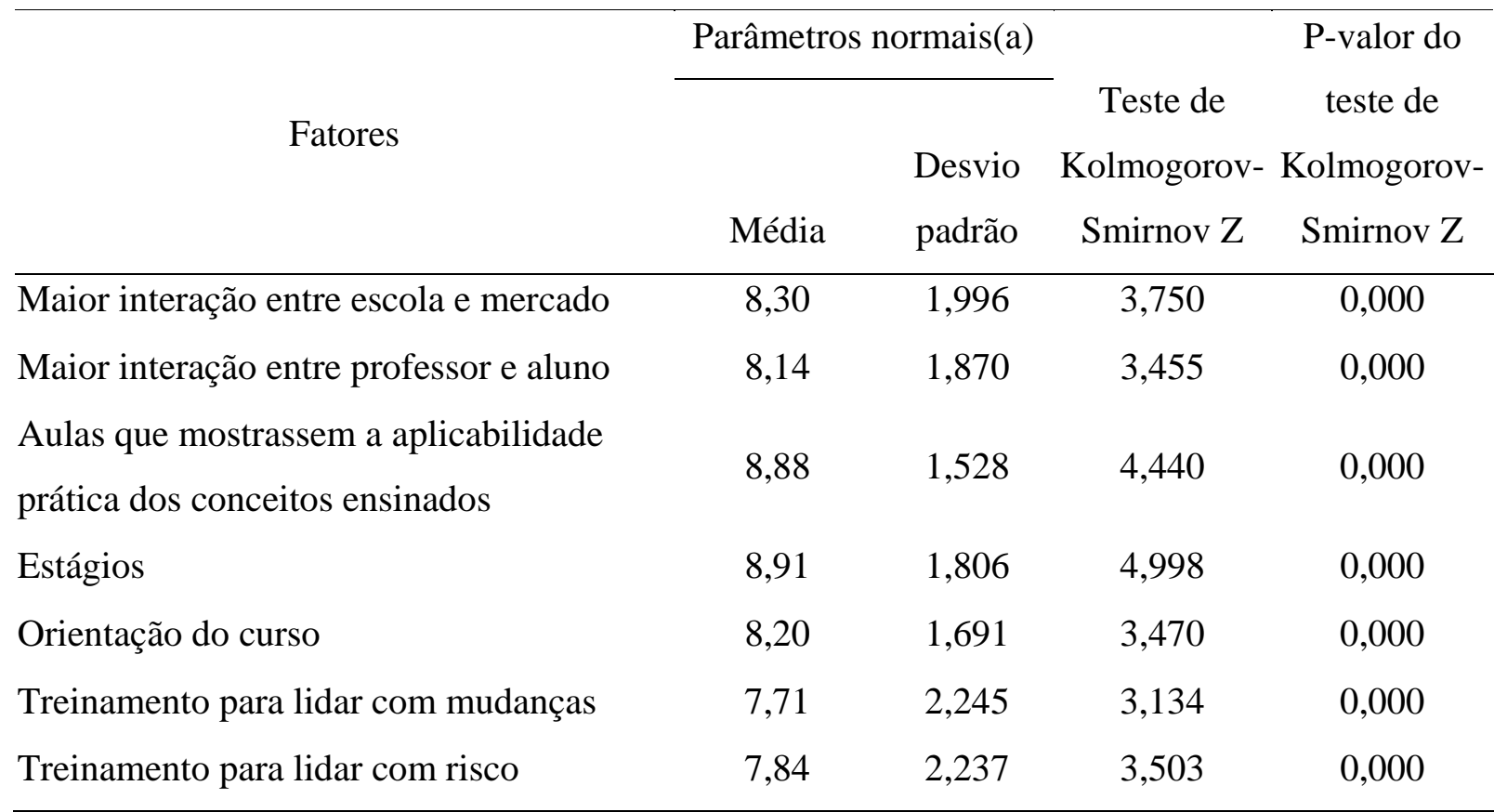

Fonte: Resultado da pesquisa.

As variáveis testadas não apresentaram ajustamento adequado para análises paramétricas. Assim, foi aplicado o teste de Friedman para averiguar se, em média, algumas das variáveis diferem em seu grau de ausência. O valor do teste de $\chi^{2}{ }_{\mathrm{c}}=225,300$ indica, com nível de significância de 1\%, que ao menos uma das causas consideradas faltou de maneira diferente, afetando negativamente e em maior intensidade o exercício da atividade ocupacional que o formandos gostariam de ocupar.

A existência de diferenças entre as médias das variáveis consideradas como aspectos que poderiam auxiliar na escolha da ocupação que gostariam de ter permite que se investigue, duas a duas variáveis se há diferença de médias. Na Tabela 17 é mostrado o resultado do teste de Wilcoxon. 
Tabela 17 - Matriz de resultados do teste de Wilcoxon para fatores que os ingressantes consideram importantes no curso universitário para auxiliá-los no desempenho profissional

\begin{tabular}{|c|c|c|c|c|c|c|c|}
\hline & $\begin{array}{l}\text { Maior } \\
\text { interação } \\
\text { entre } \\
\text { escola e } \\
\text { mercado }\end{array}$ & $\begin{array}{l}\text { Maior } \\
\text { interação } \\
\text { entre } \\
\text { professor } \\
\text { e aluno }\end{array}$ & $\begin{array}{c}\text { Aulas } \\
\text { práticas } \\
\text { sobre os } \\
\text { conceitos } \\
\text { ensinados }\end{array}$ & Estágios & $\begin{array}{c}\text { Orientação } \\
\text { do curso }\end{array}$ & $\begin{array}{c}\text { Treinamento } \\
\text { para lidar } \\
\text { com mudan } \\
\text { ças }\end{array}$ & $\begin{array}{c}\text { Treinamento } \\
\text { para lidar } \\
\text { com } \\
\text { risco }\end{array}$ \\
\hline $\begin{array}{l}\text { Maior interação } \\
\text { entre escola e } \\
\text { mercado }\end{array}$ & & $-2,220^{b}$ & $-5,037^{\mathrm{a}}$ & $-5,900^{a}$ & $-0,892^{\text {ns }}$ & $-4,433^{a}$ & $-3,454^{a}$ \\
\hline $\begin{array}{l}\text { Maior interação } \\
\text { entre professor e } \\
\text { aluno }\end{array}$ & & & $-6,924^{\mathrm{a}}$ & $-6,947^{\mathrm{a}}$ & $-0,372^{\mathrm{ns}}$ & $-3,073^{a}$ & $-2,259^{a}$ \\
\hline $\begin{array}{l}\text { Aulas práticas } \\
\text { dos conceitos } \\
\text { ensinados }\end{array}$ & & & & $-1,004^{\mathrm{ns}}$ & $-6,670^{\mathrm{a}}$ & $-8,895^{a}$ & $-8,247^{\mathrm{a}}$ \\
\hline Estágios & & & & & $-7,501^{a}$ & $-8,444^{\mathrm{a}}$ & $-7,767^{\mathrm{a}}$ \\
\hline $\begin{array}{l}\text { Orientação do } \\
\text { curso } \\
\text { Treinamento para }\end{array}$ & & & & & & $-4,280^{a}$ & $-2,664^{\mathrm{a}}$ \\
\hline $\begin{array}{l}\text { lidar com } \\
\text { mudanças } \\
\text { Treinamento para } \\
\text { lidar com risco }\end{array}$ & & & & & & & $-1,410^{\mathrm{ns}}$ \\
\hline $\begin{array}{l}\text { a - significativo } \\
\text { b - significativo } \\
\text { ns - não signific } \\
\text { Fonte: Resultado d }\end{array}$ & $\begin{array}{l}\text { a } 1 \% \\
\text { a } 5 \% \\
\text { ativo } \\
\text { pesquisa. }\end{array}$ & & & & & & \\
\hline
\end{tabular}

O número de relacionamentos cuja diferença entre as médias não é estatisticamente significante foi igual 4. Os relacionamentos considerados em que não há diferença de magnitude média e que auxiliam no desempenho da atividade que gostariam são orientação do curso e interação escola e mercado, orientação do curso e interação professor e aluno, estágio e aulas práticas e treinamento para lidar com risco e treinamento para lidar com mudanças.

A fim de se verificar se entre os grupos os fatores considerados impactaram, em média, diferentemente entre os tipos de perfil ocupacional, aplicou-se o teste de Kruskal - Wallis. Nesta questão a análise foi feita somente para o gosto, uma vez que buscou-se conhecer se havia divergência na magnitude do impacto entre a preferência pelos perfis. Os resultados deste teste são apresentados na Tabela 18. 
Tabela 18 - Teste de Kruskal - Wallis para fatores que os ingressantes consideram importantes no curso universitário para auxiliá-los no desempenho profissional

\begin{tabular}{lc}
\hline \multicolumn{1}{c}{ Fatores } & Valor do teste \\
\hline Maior interação entre escola e mercado & $18,928^{\mathrm{a}}$ \\
Maior interação entre professor e aluno & $4,321^{\mathrm{ns}}$ \\
Aulas práticas dos conceitos ensinados & $6,119^{\mathrm{b}}$ \\
Estágios & $16,252^{\mathrm{a}}$ \\
Orientação do curso & $19,175^{\mathrm{a}}$ \\
Treinamento para lidar com mudanças & $9,466^{\mathrm{a}}$ \\
Treinamento para lidar com risco & $9,655^{\mathrm{a}}$ \\
\hline
\end{tabular}

- significativo a $1 \%$

b - significativo a $5 \%$

c - significativo a $10 \%$

ns - não significativo

Fonte: Resultado da pesquisa.

O aspecto maior interação entre professor e aluno foi o único que não apresentou média estatisticamente diferente entre os perfis considerados. No entanto, o teste não permite que se afirme quais dos grupos considerados apresentam maior média para os demais aspectos que os estudantes acreditam que os auxiliará na escolha da atividade que desejam desempenhar.

\subsubsection{Análise Estatística da amostra de estudantes formandos}

A análise dos dados dos formandos reflete dados mais realísticos, pois estes estão diante de uma decisão, diferentemente dos ingressantes, que ainda terão quatro ou cinco anos para terminar de formar seu gosto e sua intenção. A maioria dos formandos ingressou nas escolas nos anos de 2002 e 2003, respectivamente, 43,6\% e 47,9\%. A primeira variável a ser analisada é a variável gênero, em que se verifica que as mulheres não são a maioria dentre os formandos, entretanto, a diferença entre homens e mulheres não é discrepante. A participação das mulheres no total de formandos é de 45,1\%. Verifica-se que em cursos como Ciências dos Alimentos, Ciências Biológicas e Gestão Ambiental há predominância de mulheres, respectivamente 77,8\%, 75,0\% e 
71,4\%. Na Figura 28 apresenta-se a distribuição, por curso, do gosto por uma ocupação profissional, considerando-se o gênero.

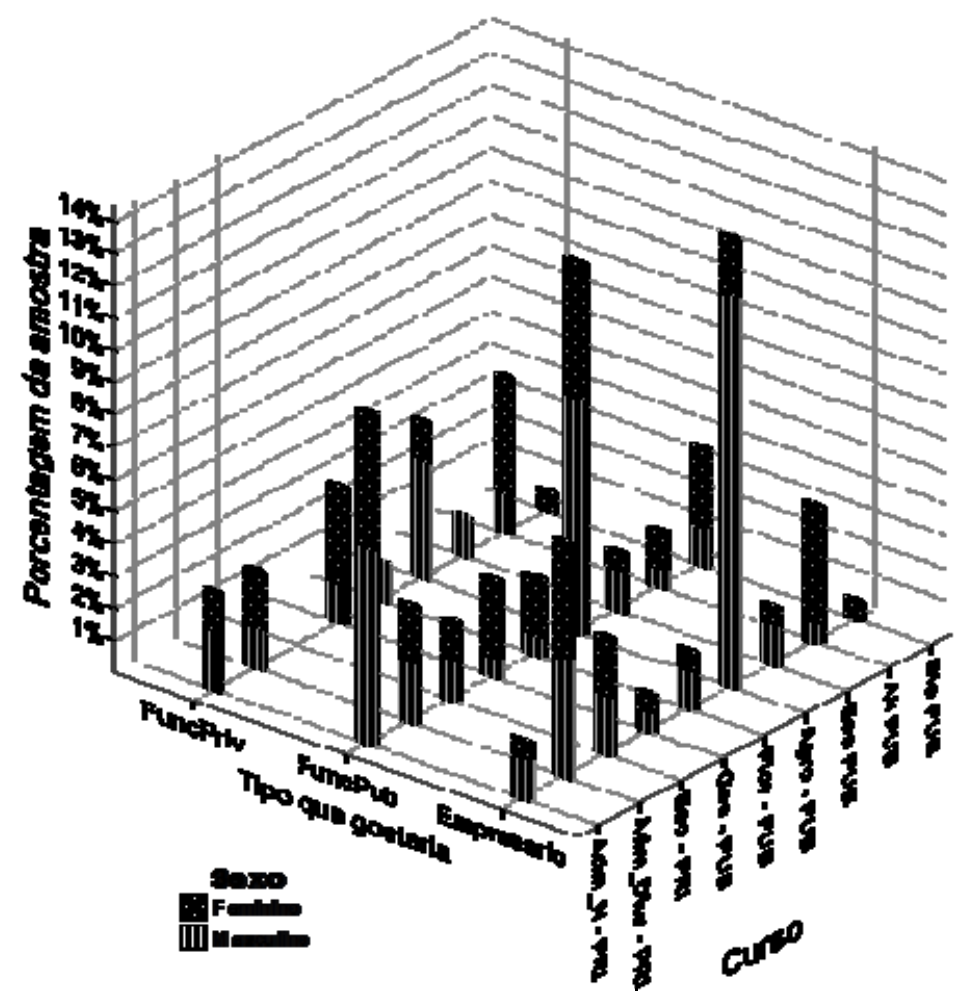

Figura 28 - Porcentagem de alunos formandos que determinaram a escolha por uma opção considerando-se o gênero

Fonte: Resultados da pesquisa.

A amostra de formandos confirma o comportamento já notado pela literatura e da amostra de ingressantes. As mulheres têm menor preferência por ocupações empresariais quando comparadas aos homens. Considerando-se o gênero feminino, as mulheres têm preferência por ocupar cargos na iniciativa pública, seguido por atividades empresariais e funcionalismo da iniciativa privada, respectivamente, $44,0 \%, 30,7 \%$ e 25,3\%. Dentre os 60 estudantes que revelaram o desejo de ser empresários, as mulheres representam 38,3\%. As freqüências entre as respostas acerca do gosto entre as alunas ingressantes e formandas são diferentes, dado o nível de significância do teste de qui-quadrado de 0,000. Assim, rejeita-se a hipótese de não haver 
diferença entre as freqüências. Comparando-se com os 26,8\% das alunas ingressantes, houve um significativo aumento entre o grupo de gênero feminino no gosto por desempenhar atividades empresariais. O gênero masculino apresenta comportamento diferente das mulheres com respeito ao gosto. A ocupação mais preferida entre os homens é a empresarial, seguida por funcionalismo público e funcionário da iniciativa privada, respectivamente, 41,1\%, 37,8\% e 21,1\%. Com relação ao gosto dos estudantes ingressantes e formandos de sexo masculino, quanto ao perfil ocupacional, há diferença nas freqüências das respostas. O valor do teste de qui-quadrado foi de 8,232. As relações entre ingressantes e formandos são estatisticamente significativas, o valor do teste de qui-quadrado é significante ao nível de 0,016. O desejo dos formandos do gênero masculino é diferente dos ingressantes de mesmo gênero, recordando que para estes últimos, os homens seguem o ordenamento de preferência igual ao das mulheres ingressantes. Observa-se um significativo crescimento nos homens formandos quando comparados aos ingressantes com relação ao gosto por atividades empresariais, dado que os formandos com esse desejo são 41,1\%, enquanto os ingressantes com o desejo por atividades empresariais representam 28,9\%.

Analisando-se a crença em se tornar empresário no futuro, por gênero, verifica-se que há uma variação nos percentuais. A afirmação baseia-se nos resultados do teste de qui-quadrado para as freqüências relacionadas à crença de ocupar as posições profissionais consideradas. O valor do teste de qui-quadrado foi de 10,284, valor que é significante ao nível de 0,006. No gênero feminino houve aumento da participação no grupo com respeito à crença de ser empresárias. Das mulheres formandas, em torno de 33,3\% delas acreditam que exercerão atividades empresariais, enquanto o percentual com gosto é igual a 30,7\%. Este comportamento é similar ao verificado ao das ingressantes, pois houve aumento também do percentual de mulheres que acreditam que serão empresárias quando comparado ao percentual das que desejam ser empresárias. Considerando-se o grupo dos que acreditam que serão empresários, isto é, homens e mulheres com a crença de desempenhar atividades empresariais, a participação das mulheres no grupo das que acreditam que serão empresárias também aumentou, este grupo é composto por $44,6 \%$ de mulheres. A maioria das mulheres acreditam que atuarão na iniciativa privada como funcionárias, 42,7\%, seguido por atividades empresariais, 33,3\% e serviços públicos, 24,0\%. Estes percentuais são diferentes dos verificados entres as ingressantes, cujo ordenamento é funcionária da iniciativa privada, serviço público e atividades empresariais. O gênero masculino também apresentou mudança de comportamento quando se compara o gosto com a crença. $\mathrm{O}$ 
ordenamento da crença é: empregado na iniciativa privada, atividades empresariais e funcionalismo público. A comparação entre a intenção e o gosto revela que o grupo referente à trabalhar na iniciativa privada como funcionário apresentou significativo aumento de 21,1 pontos percentuais. Tal resultado se deu em razão da redução dos percentuais dos grupos funcionalismo público e atividades empresariais; entretanto, a redução foi menor no grupo de atividades empresariais. Os homens que gostariam de ser empresários são 41,1\% da amostra masculina e os que acreditam são 34,3\%, uma redução de 6,7 pontos percentuais. As relações entre a crença dos homens ingressantes e formandos não são estatisticamente significativas, o valor do teste de quiquadrado foi de 4,518 e o nível de significância foi de 0,104.

A questão que visava identificar onde os estudantes nasceram apresentou um grande número de cidades, exatamente 66 cidades. Mas, com relação aos estados não se verifica esta heterogeneidade; os estudantes nasceram em 10 estados diferentes, mais o Distrito Federal. A representatividade dos estados, exceto São Paulo, é pequena. A cidade com maior participação na amostra é Piracicaba, seguida de São Paulo e Campinas. A participação destas cidades na origem dos estudantes é respectivamente de 29,1\%, 15,2\% e 5,8\%. Com relação ao estado de origem, São Paulo tem a maior participação, com 91,5\% dos estudantes. O estado com segundo maior percentual é Minas Gerais, com 2,4\%, seguido por Piauí, com 1,2\%. Para os demais estados havia um estudante de cada um deles. Do percentual de alunos da cidade de Piracicaba, a maioria está se formando pela PRI, em torno de $75 \%$.

O questionário aplicado buscou avaliar a relação religiosidade com gosto e crença profissional. O grupo religioso com maior participação é o de seguidores do catolicismo, representando 67,9\% da amostra, seguido por agnósticos e ateus, 12,1\% e espíritas, 8,5\%. Comparando-se com a amostra de ingressantes verifica-se que o percentual de católicos é similar, entretanto, o número de evangélicos se reduziu em 2,5 pontos percentuais. Na Figura 29 é apresentada a contagem das declarações dos formandos associanda com a freqüência com que visitam o templo da religião que declararam seguir. 


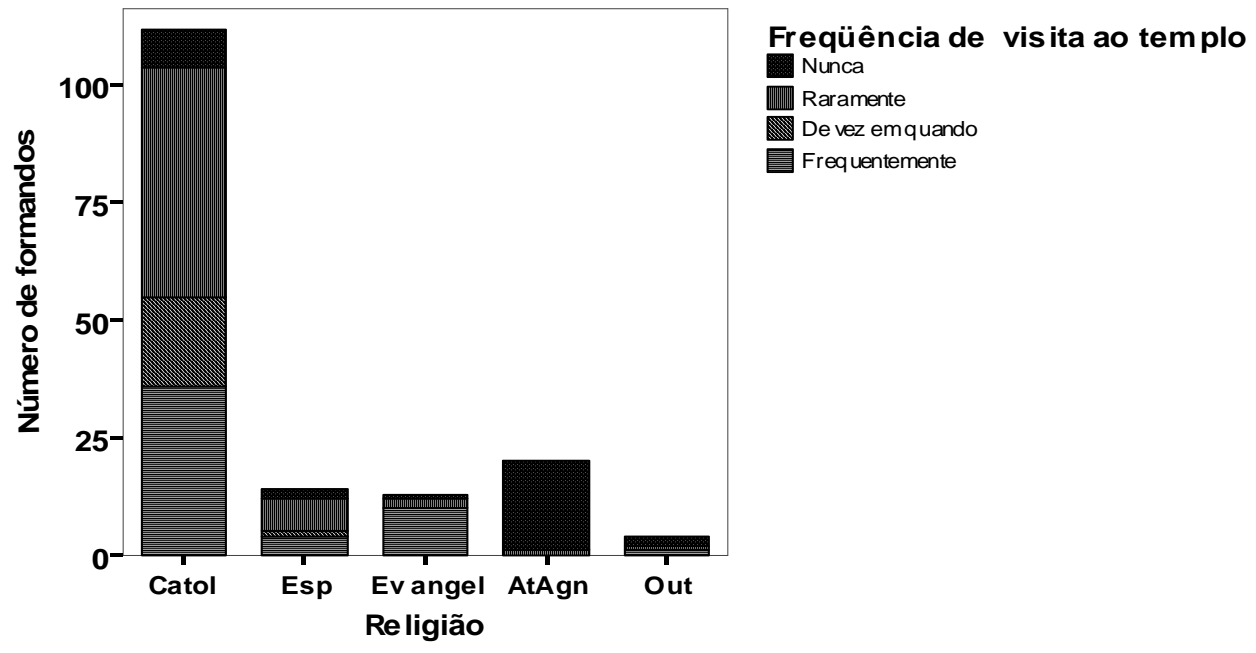

Figura 29- Número de formandos por religião e freqüência ao templo religioso Fonte: Resultados da pesquisa

Dentre os estudantes formandos católicos 50,9\% declararam que nunca freqüentam, ou então raramente vão ao templo da religião. Entre os evangélicos, em torno de $76,9 \%$ vão freqüentemente ao templo de sua denominação. Visando identificar se existe influência da religião e a freqüência de visita ao templo religioso na preferência ocupacional são apresentados na Figura 30 os percentuais dos questionários válidos associados ao relacionamento entre tais variáveis. Do grupo dos 60 estudantes formandos que gostariam de ser empresários, 75,0\% declararam-se católicos. No grupo dos 112 que se declararam católicos a preferência é por desempenhar atividades empresariais, em torno de 40,2\%. O grupo que se declara espírita é o com menor interesse em desempenhar atividades empresariais, em torno de $21,4 \%$ dos pertencentes a este grupo gostariam de ser empresários. 


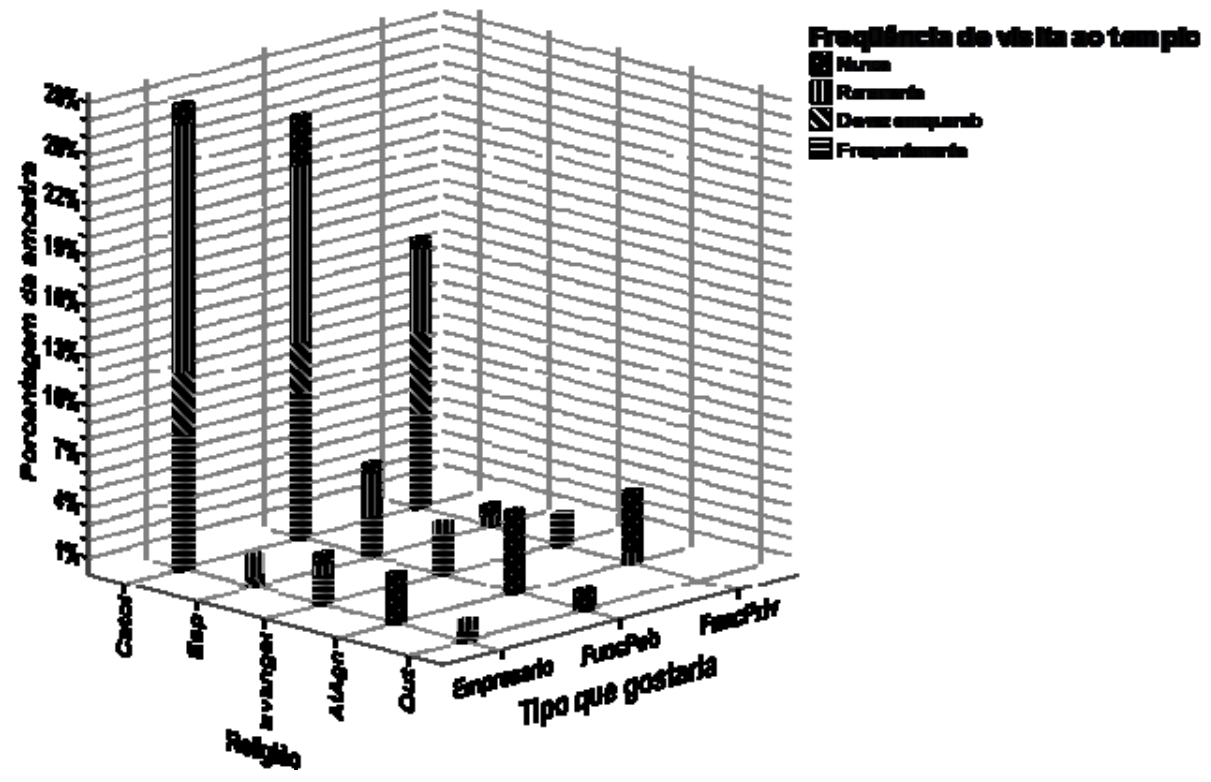

Figura 30- Porcentagem dos questionários válidos por opção ocupacional e religião considerando-se a freqüência de visita ao templo da religião

Fonte: Resultados da pesquisa

Analisando-se os grupos de alunos que acreditam que serão empresários verifica-se que os católicos continuam a ter maior crença de que serão empresários. Do grupo que acredita que será empresário, em torno de 80,4\% se declaram católicos. Contrastando com o percentual do grupo empresarial pelo gosto, verifica-se que há um aumento com relação à intenção de se empresário de 5,4 pontos percentuais. Mesmo comportamento foi verificado entre os ingressantes, aumentando o número de católicos dentro do grupo com intenção de atuar como empresários. Os estudantes que se declaram católicos, em torno de 40,27\% acreditam que atuarão como empresários, 37,5\% como funcionários da iniciativa privada e 22,3\% no setor público. Os percentuais referentes ao gosto ser funcionário da iniciativa priva e ser funcionário do setor público apresentaram uma inversão em relação aos percentuais de gosto. Comparando-se com os resultados da intenção dos ingressantes verifica-se um significativo aumento na intenção de ser empresário, no grupo dos ingressantes o ordenamento é funcionários da iniciativa privada, com 34,9\% que estarão no setor público, e 22,5\% que acreditam que serão empresários. 
No questionário foi incluída a variável idade a fim de se verificar o relacionamento com a escolha ocupacional, já que na literatura é tida como importante na escolha ocupacional. $\mathrm{Na}$ Tabela 19 é apresentada a estatística descritiva desta variável para os questionários válidos.

Tabela 19 - Estatística descritiva para a variável idade

\begin{tabular}{|c|c|}
\hline Estatísticas & Idade \\
\hline Número de observações & 165 \\
\hline Média & 23,97 \\
\hline Mediana & 23 \\
\hline Desvio Padrão & 3,889 \\
\hline Assimetria & 3,936 \\
\hline Curtose & 19,197 \\
\hline Mínimo & 20 \\
\hline Máximo & 49 \\
\hline
\end{tabular}

Fonte: Resultados da pesquisa

Conclui-se pelos resultados da estatística descritiva que há outliers; um dos indicativos é que o valor da média difere da mediana. O valor de assimetria da variável idade sugere que a distribuição desta variável é assimétrica positiva. A inspeção do histograma com ajustamento de uma curva de distribuição normal é apresentada na Figura 31. 


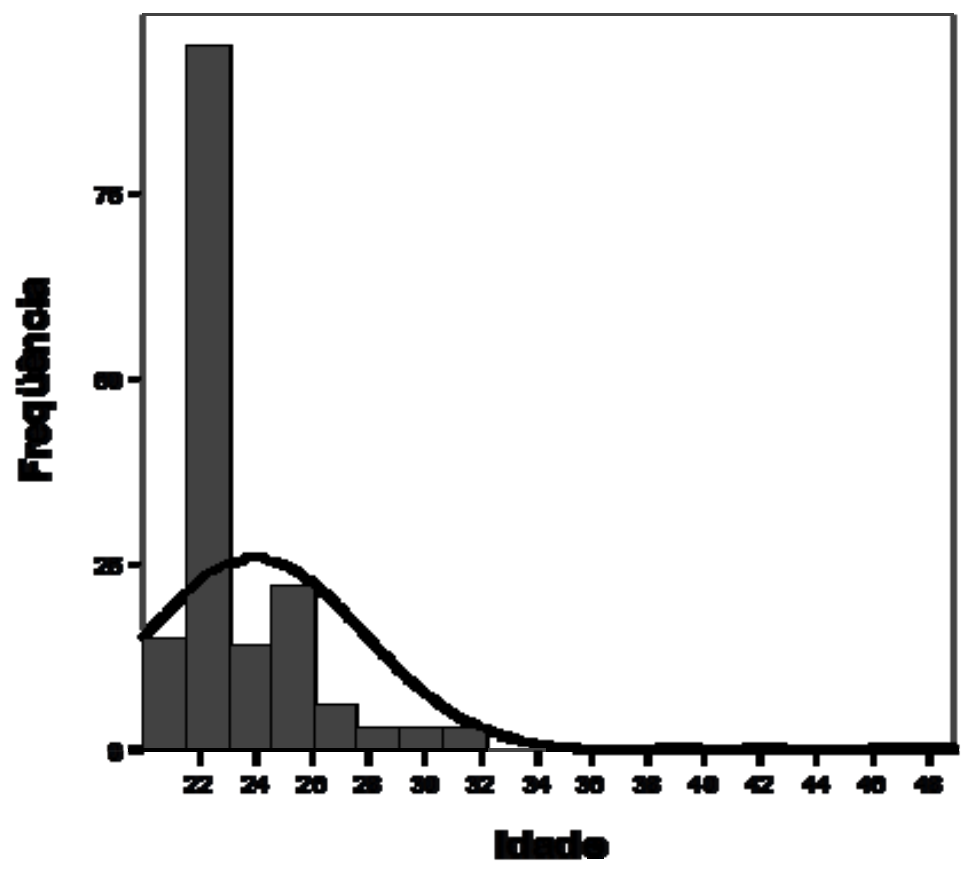

Figura 31 - Histograma com curva de ajustamento normal da variável idade Fonte: Resultado da pesquisa.

A elaboração de um gráfico boxplots permitiu a inspeção da presença de outliers e valores extremos. Este gráfico foi elaborado considerando-se as categorias de escolha ocupacional, conforme pode ser verificado na Figura 32. 


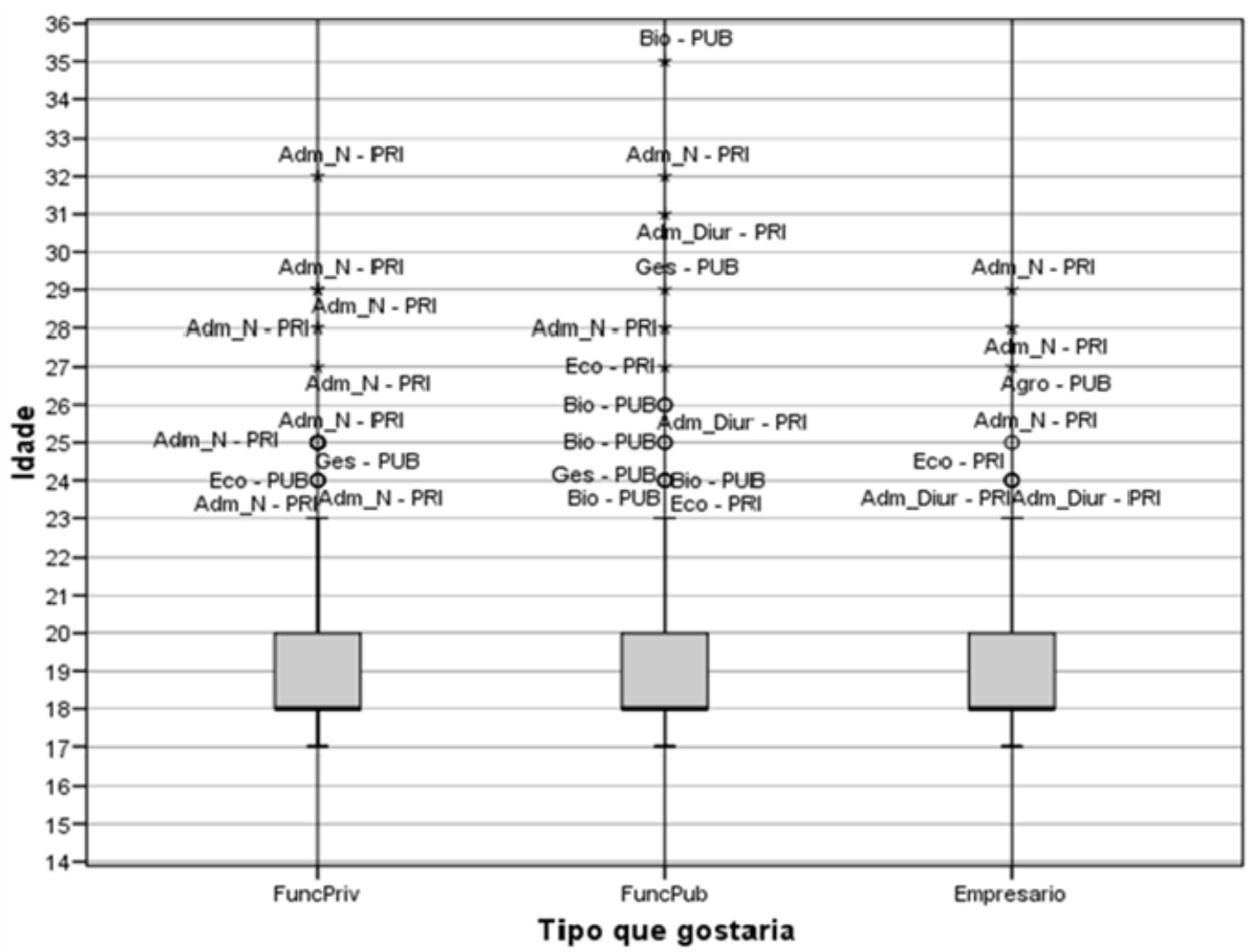

Figura 32 - Boxplots para avaliação da presença de outliers e valores extremos Fonte: Resultados da pesquisa.

Na Figura 32 os valores indicados por círculos referem-se à posição de outliers no banco de dados, enquanto por estrela indicam a localização de valores extremos. Os rótulos ao lado dos símbolos de outliers e valores extremos indicam o curso desta observação. Para todas as opções ocupacionais, idades superiores a 23 anos foram considerados como outliers. Pode-se inferir, a partir desta figura, que a mediana entre os grupos é igual, 19 anos, e considerando-se a existência de outliers, a média não é uma medida apropriada.

No questionário foi incorporada uma questão sobre estado civil com a finalidade de conhecer o relacionamento entre estado civil e escolha ocupacional. No entanto, verifica-se predominância no grupo de solteiros, em torno de 95,8\% da amostra. Este percentual é semelhante ao da amostra de ingressantes e possivelmente é em decorrência do perfil de idade da amostra, que é composta predominantemente por jovens.

A variável renda familiar mensal também pode ser um aspecto importante no processo de escolha ocupacional. Os estudantes com renda entre 5 a 10 salários mínimos representam o maior 
percentual, aproximadamente 30,3\%. A faixa com segunda maior participação foi a de renda mensal entre 11 a 15 salários mínimos, com 23,0\% e como terceiro maior grupo estão os estudantes com renda familiar maior que 20 salários mínimos, em torno de 21,2\%. A distribuição de renda entre os formandos difere da dos ingressantes; o grupo mais representativo entre os ingressantes é também o de 5 a 10 salários mínimos, mas com participação maior, igual a 37,8\% daquela amostra. Em seqüência, no grupo dos estudantes ingressantes tem-se a faixa entre 01 a 04, com 21,3\%, e entre 11 a 15 salários mínimos, com 21,0\%. É oportuno salientar novamente que o questionamento sobre a renda pode apresentar distorções, já que as pessoas podem subestimar ou superestimar a declaração sobre os rendimentos. Na Figura 33 é apresentado um histograma da distribuição da amostra por nível de renda.

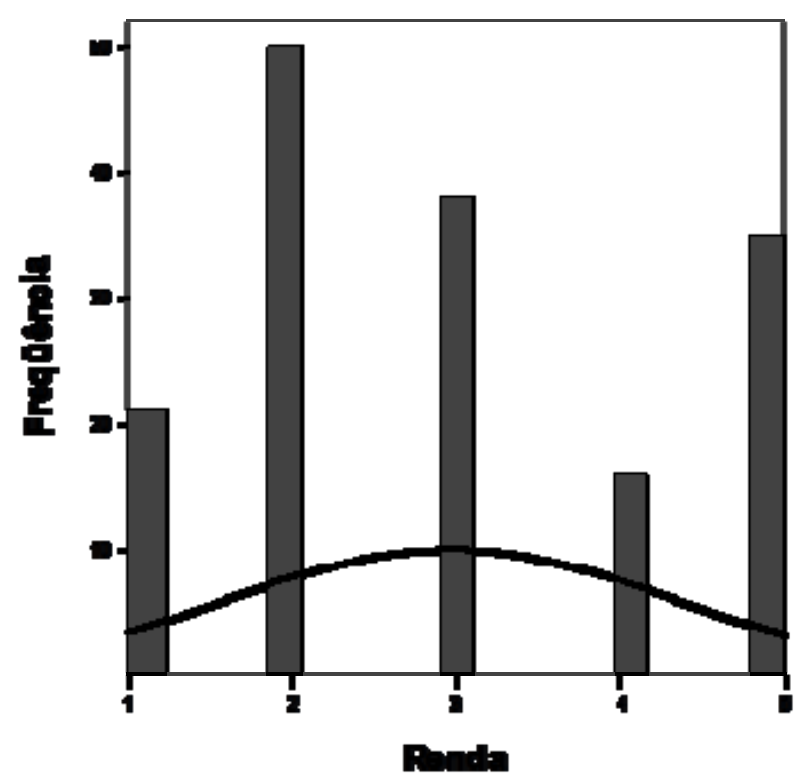

Figura 33 - Histograma com curva de ajustamento normal da variável renda Fonte: Resultado da pesquisa.

Na Figura 34 observa-se que houve observações que constam renda igual a zero, estas são referentes a pessoas que não responderam a esta questão. A distribuição da variável renda aproxima-se de uma distribuição normal, há uma assimetria positiva. O relacionamento da faixa de renda familiar e preferência ocupacional controlada por curso é apresentada na Figura 25 A faixa de renda familiar entre 05 a 10 salários mínimos é a com o maior percentual de gosto por 
atividades empresariais, cerca de 39,0\% destes estudantes gostariam de serem empresários. Também nesta faixa de renda, considerando-se os 50 elementos deste grupo, a preferência é por atividades empresariais, cerca de 46,0\%. A faixa de mais de 20 salários mínimos é a segunda maior em participação dentre aqueles que têm gosto por atividades empresariais. Dos indivíduos de famílias com esta renda, em torno de 48,6\% gostariam de ser empresários. Aqueles cuja renda familiar é de 16 a 20 salários mínimos há também maior preferência por atividades empresariais, 43,8\%. O gosto por atividades no setor público é maior na faixa de 01 a 04 salários mínimos. Dos que declaram este nível de renda, 21 estudantes, 61,9\% gostariam de ser funcionário público. A atividade no setor público dentre aqueles com renda superior a 20 salários mínimos tem comportamento diferente do grupo de ingressantes. No grupo de estudantes ingressantes com renda familiar acima de 20 salários mínimos, em torno de 18,5\% apontaram que gostariam de ocupar cargos públicos, enquanto no grupo de formandos este percentual aumenta para 34,3\%.

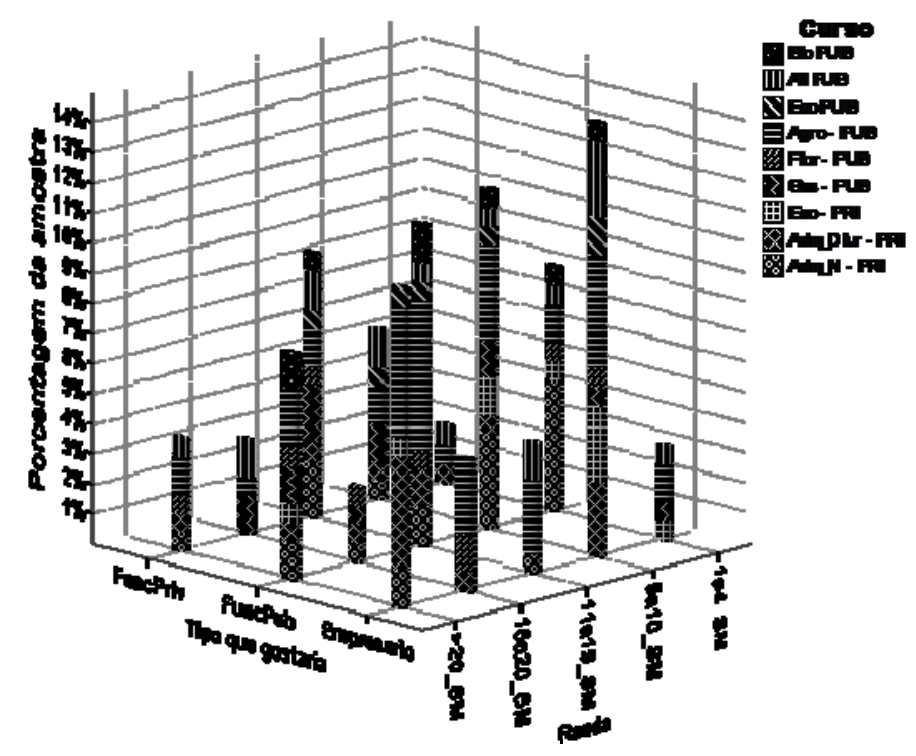

Figura 34 - Preferência ocupacional por faixa de renda familiar mensal, considerando-se o curso Fonte: Resultados da pesquisa.

Contrastando o grupo de formandos com o grupo de ingressantes verifica-se que o grupo que declarou pertencer à faixa salarial de 5 a 10 salários mínimos tem maior participação em ambas as amostras. No entanto, houve diferença nas atividades em que os estudantes gostariam 
de atuar. A maior parcela dos ingressantes que pertencem a esta faixa gostariam de ser funcionários da iniciativa privada, em torno de $46 \%$, seguidos de funcionalismo público, 36,3\% e empresários, 17,7\%. Observa-se com relação aos formandos uma inversão dos percentuais de empregados da iniciativa privada e empresários. O ordenamento na amostra dos formandos foi, em primeiro lugar, empresários, 46\%, seguido por funcionalismo público, 36\%, e empregado da iniciativa privada, $18 \%$.

A ligação entre a crença de desempenhar uma ocupação e renda familiar mensal mostrou que houve variações dentro de cada grupo de renda pelas preferências empresariais. No grupo de 01 a 04 salários mínimos houve um significativo aumento do perfil empresarial de 23,8 pontos percentuais dentro do grupo com esta renda familiar mensal. Nas demais faixas de renda familiar mensal o confronto do perfil empresarial dentro da classe de renda indica que houve uma redução do percentual de estudantes que acreditam que serão empresários. O grupo que apresentou maior redução foi o de 05 a 10 salários mínimos, em que a redução da participação do perfil empresarial dentro deste grupo foi igual a 16 pontos percentuais. O grupo de 01 a 04 salários mínimos apresentou também redução dos que acreditam que serão funcionários públicos quando contrastado com os que gostariam de trabalhar no setor público. O percentual de gosto por ser funcionário público era de 61,9\%, enquanto a parcela de estudantes que acreditam que serão funcionários públicos é de 14,3\%.

A questão 16 do questionário tinha a pretensão de avaliar o perfil de risco dos estudantes e o relacionamento entre a opção ocupacional e atitude em relação ao risco. Para tal finalidade foi criado um cenário com uma loteria em que o estudante tinha que declarar a sua disposição a pagar pelo bilhete. Nesta fase da pesquisa, esta questão não continha dois itens que foram incorporados ao questionário dos ingressantes, a fim de entender a freqüência do valor zero. $\mathrm{Na}$ amostra houve sete estudantes que não declararam o valor que pagariam.

A análise das freqüências dos valores assinalados indicou que dois valores são modas, o valor zero e o valor dez. O total de respondentes destes valores foi de 27,8\% e estes valores foram os que tiveram maior participação dentre os informados pelos estudantes. Na Tabela 20 é apresentada a estatística descritiva desta questão para os estudantes que declararam que pagariam para participar da loteria proposta no questionário. 
Tabela 20 - Estatística descritiva da disposição a pagar por um bilhete de loteria

\begin{tabular}{|c|c|}
\hline Estatísticas & Idade \\
\hline Número de observações & 158 \\
\hline Média & 232,71 \\
\hline Mediana & 10,00 \\
\hline Desvio Padrão & 968,44 \\
\hline Assimetria & 0,286 \\
\hline Curtose & $-1,138$ \\
\hline Mínimo & 0 \\
\hline Máximo & $10.000,00$ \\
\hline
\end{tabular}

Fonte: Resultados da pesquisa

Os resultados da estatística descritiva indicam que há uma grande amplitude dos dados. A média não é uma boa medida da variável. O valor R\$1,00 foi respondido por 12,7\% da amostra e o valor R\$ 5,00 por 10,3\% dos estudantes. Comportamento semelhante ao dos ingressantes, que responderam estes valores com maior freqüência. E conforme já salientado, há uma associação entre o valor $\mathrm{R} \$ 1,00$ e o valor vigente da loteria oficial no período da aplicação dos questionários. Na Figura 35 é apresentada a distribuição da disposição declarada a pagar associada à faixa de renda. 


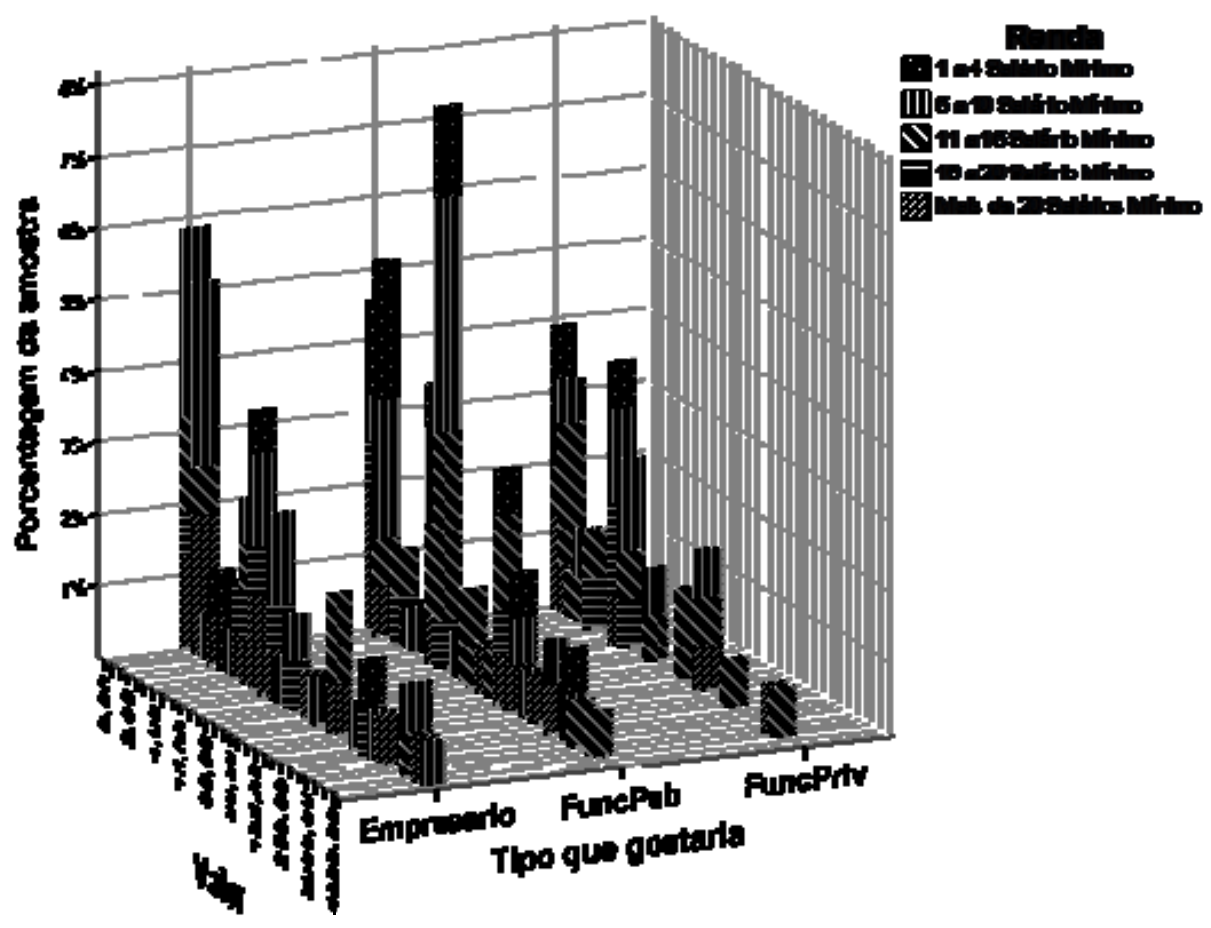

Figura 35 - Disposição dos alunos formandos a pagar por um bilhete de loteria dado o gosto por uma preferência ocupacional, considerando-se a renda familiar mensal

Fonte: Resultado da pesquisa

Pode-se observar que dentre aqueles que não pagariam para participar da loteria, a maior parte, 39,1\% declararam que gostariam de ser empresários. No grupo de ingressantes verifica-se que dentre os que gostariam de ocupar posições empresariais a maior parte não pagaria pelo bilhete, em razão de seus princípios. Entre os formandos observa-se um comportamento semelhante ao do grupo de formandos com gosto empresarial, o maior percentual é daqueles que não pagariam para participar da loteria. O grupo dos formandos com gosto empresarial e que não pagariam para participar do sorteio é igual a 15,5\% da amostra. Verifica-se que cerca de 31,0\% dos formandos com gosto de ser empresários pagariam um dos valores de $\mathrm{R} \$ 1,00$, $\mathrm{R} \$ 5,00$, ou $\mathrm{R} \$ 10,00$. 
O confronto entre disposição a pagar pelo bilhete e a renda familiar permite a avaliação do comportamento de risco de acordo com a situação financeira familiar. Na Figura 36 é apresentada a distribuição da disposição a pagar declarada pelos formandos, por faixa de renda.
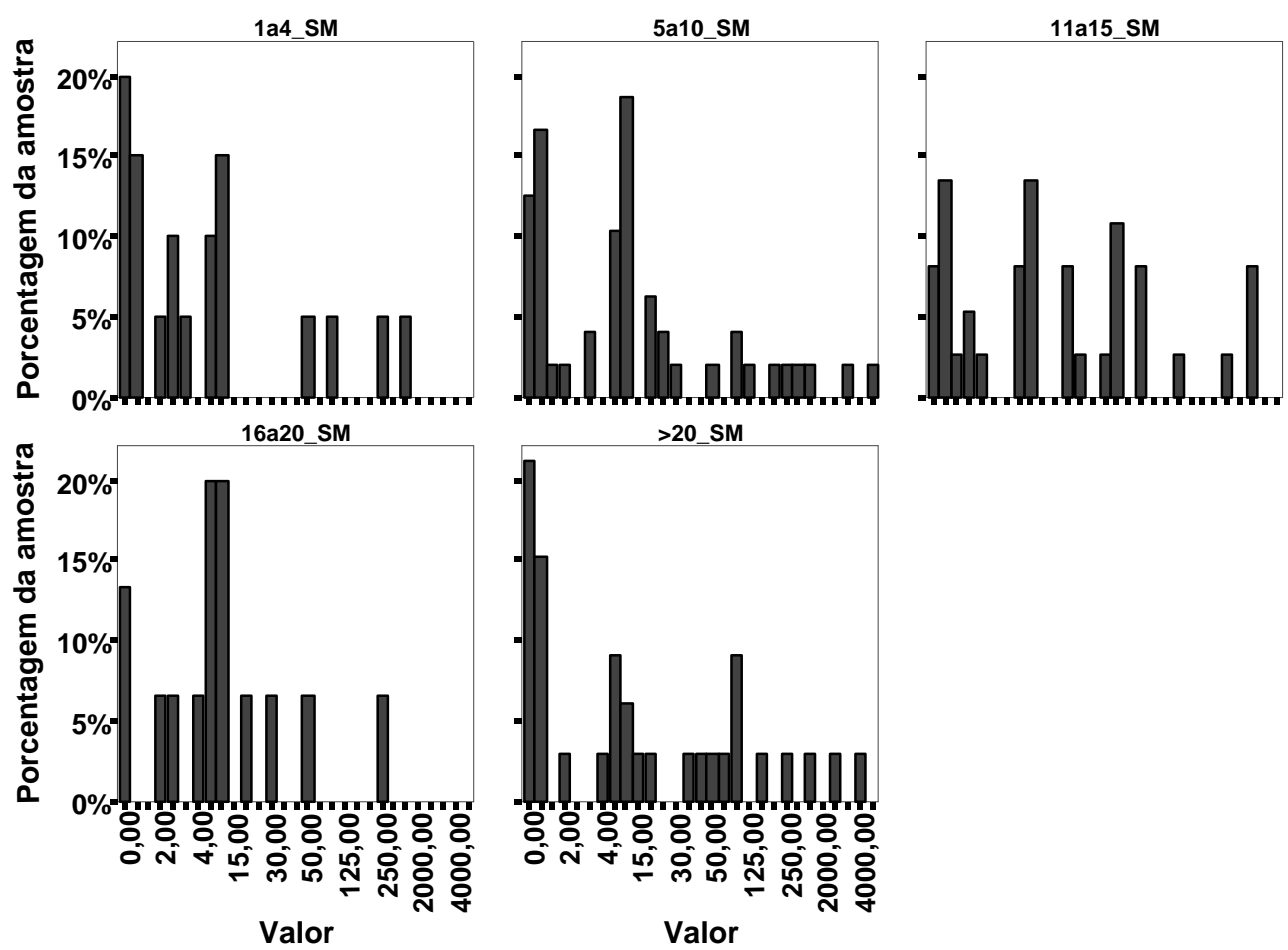

Figura 36 - Disposição dos formandos a pagar por um bilhete de loteria, de acordo com a renda familiar mensal

Fonte: Resultado da pesquisa

Na literatura é discutida a relação renda e risco, com indicações de que indivíduos com maior renda são mais propensos a aceitar maiores riscos. A verificação deste comportamento na amostragem não foi encontrada, percebe-se que na faixa de rendimentos mais elevados não há propensão a pagar mais pelos bilhetes. Observa-se um comportamento contrário em que a amostra de mais de 20 salários mínimos tem comportamento similar ao de 1 a 4 salários mínimos.

A análise das questões cuja medida é em escala foi realizada através de testes não paramétricos. Tais questões visavam identificar quais fatores influenciavam na escolha ocupacional. Os testes aplicados serão: teste de normalidade de Kolmogorov - Smirnov, teste de Friedman, teste de Wilconxon e teste de Krustal-Wallis. A aplicação destes testes tem como 
objetivo identificar quais dos fatores são importantes na escolha ocupacional da amostra do estudo e se há diferença entre os perfis ocupacionais considerados.

A primeira questão a ser analisada é a 12, que questionava o estudante acerca do grau de influência de fatores selecionados que influenciavam na não intenção de atuar na atividade que gostaria. A fim de verificar se as variáveis seguiam uma distribuição normal, foi aplicado o teste de normalidade de Kolmogorov - Smirnov. Na Tabela 21 são apresentados os resultados deste teste.

Tabela 21 - Teste de Normalidade de Kolmogorov - Smirnov para os fatores que impedem com que as preferências ocupacionais dos formandos não correspondam às posições que gostariam de ocupar

\begin{tabular}{|c|c|c|c|c|}
\hline \multirow{3}{*}{ Fatores } & \multicolumn{2}{|c|}{ Parâmetros normais } & \multirow{3}{*}{$\begin{array}{c}\text { Teste de } \\
\text { Kolmogorov- } \\
\text { Smirnov Z }\end{array}$} & \multirow{3}{*}{$\begin{array}{c}\text { P-valor do teste } \\
\text { de Kolmogorov- } \\
\text { Smirnov Z }\end{array}$} \\
\hline & & Desvio & & \\
\hline & Média & Padrão & & \\
\hline Acesso a financiamento & 6,49 & 3,451 & 2,092 & 0,000 \\
\hline Orientação familiar & 4,69 & 3,192 & 1,231 & 0,096 \\
\hline $\begin{array}{l}\text { Treinamento formal } \\
\text { deficiente }\end{array}$ & 2,63 & 3,244 & 2,707 & 0,000 \\
\hline Política econômica do país & 3,62 & 2,839 & 1,717 & 0,006 \\
\hline $\begin{array}{l}\text { Questões institucionais do } \\
\text { país }\end{array}$ & 6,02 & 2,971 & 1,711 & 0,006 \\
\hline $\begin{array}{l}\text { Acredita que não tem chances } \\
\text { de sucesso fazendo o que }\end{array}$ & 5,74 & 2,702 & 1,617 & 0,011 \\
\hline gostaria & & & & \\
\hline
\end{tabular}

Fonte: Resultados da pesquisa

A análise dos resultados do teste recomenda cuidado ao se utilizar os valores calculados de média e desvio padrão. O ajustamento da curva de distribuição normal para as variáveis treinamento formal, política econômica e questões institucionais, com nível de significância de 1\% não é estatisticamente diferente de zero. As variáveis acredita que não tem chances de sucesso e orientação familiar podem também ser consideradas como não se distribuindo 
normalmente nos níveis de significância de 5\% e 10\%, respectivamente. Desta forma, foram aplicados os testes não paramétricos para a discussão acerca destes fatores.

O primeiro teste aplicado é o de Friedman, cujo intuito é avaliar se alguns dos fatores listados na Tabela 21 têm médias ranqueadas diferentes. Em caso positivo, isto é, as médias ranqueadas são diferentes, tem-se que os fatores considerados como influenciadores na escolha ocupacional não impactam em mesma magnitude média. O resultado deste teste indica que os fatores não afetam de maneira análoga na escolha das áreas que os formandos acreditam que estarão desempenhando. O valor do teste de $\chi^{2} \mathrm{c}=240,069$ indica, no nível de significância de $1 \%$, que ao menos um dos fatores considerados impede de maneira diferente que a crença corresponda ao gosto.

O resultado do teste de Friedman revelou que os fatores considerados diferem uns dos outros ao não corresponderem ao cargo que os formandos gostariam de ocupar. No entanto, não é possível identificar detalhes acerca da diferença da influência. Desta maneira, foi aplicado o teste de Wilcoxon para identificar, comparando-se 2 a 2, os fatores que apresentam diferença de média.

Na Tabela 22 são apresentados os resultados obtidos pelo teste de Wilcoxom. Verifica-se que a maior parte dos pares analisados apresentou diferença da média estatisticamente significativa, considerando-se até 10\% de nível de significância. 
Tabela 22 - Matriz de resultados do teste de Wilcoxon para a diferença entre os fatores que impedem que a crença não corresponda ao gosto ocupacional dos formandos

\begin{tabular}{|c|c|c|c|c|c|c|c|}
\hline & $\begin{array}{l}\text { Recursos } \\
\text { financeiros } \\
\text { próprios }\end{array}$ & $\begin{array}{l}\text { Acesso } \\
\text { a } \\
\text { financia } \\
\text {-mento }\end{array}$ & $\begin{array}{l}\text { Orientação } \\
\text { familiar }\end{array}$ & $\begin{array}{l}\text { Treinamento } \\
\text { formal } \\
\text { deficiente }\end{array}$ & $\begin{array}{l}\text { Política } \\
\text { econômica } \\
\text { do país }\end{array}$ & $\begin{array}{l}\text { Questões } \\
\text { institucionais } \\
\text { do país }\end{array}$ & $\begin{array}{l}\text { Possibilidade } \\
\text { de insucesso na } \\
\text { atividade }\end{array}$ \\
\hline $\begin{array}{l}\text { Recursos } \\
\text { Financeiros } \\
\text { próprios }\end{array}$ & & $-6,416^{\mathrm{a}}$ & $-8,343^{a}$ & $-6,804^{\mathrm{a}}$ & $-1,422^{\mathrm{ns}}$ & $-2,285^{b}$ & $-8,439^{a}$ \\
\hline $\begin{array}{l}\text { Acesso a } \\
\text { Financiamento }\end{array}$ & & & $-5,262^{a}$ & $-3,043^{\mathrm{a}}$ & $-4,128^{a}$ & $-3,366^{a}$ & $-6,470^{a}$ \\
\hline $\begin{array}{l}\text { Orientação } \\
\text { familiar }\end{array}$ & & & & $-3,211^{a}$ & $-7,618^{\mathrm{a}}$ & $-7,518^{a}$ & $-1,986^{b}$ \\
\hline $\begin{array}{l}\text { Treinamento } \\
\text { formal } \\
\text { deficiente }\end{array}$ & & & & & $-6,604^{a}$ & $-6,472^{a}$ & $-5,140^{a}$ \\
\hline $\begin{array}{l}\text { Política } \\
\text { econômica do } \\
\text { país }\end{array}$ & & & & & & $-1,727^{\mathrm{c}}$ & $-8,482^{\mathrm{a}}$ \\
\hline $\begin{array}{l}\text { Questões } \\
\text { Institucionais } \\
\text { do país } \\
\text { Possibilidade } \\
\text { de insucesso } \\
\text { na atividade }\end{array}$ & & & & & & & $-8,586^{a}$ \\
\hline
\end{tabular}

a - significativo a $1 \%$

b - significativo a $5 \%$

c - significativo a $10 \%$

ns - não significativo

Fonte: Resultados da pesquisa

As variáveis política econômica do país e recursos financeiros próprios apresentaram média igual, uma vez que o teste foi não significativo para elas. Este par de variáveis na amostra de ingressantes apresenta o mesmo comportamento. Desta forma, reforça-se a sugestão de que os estudantes consideram que as variáveis política econômica do país e recursos financeiros próprios, estejam correlacionadas. Na amostra dos ingressantes, outra relação de duas variáveis, questões institucionais do país e recursos financeiros próprios, apresenta média igual, entretanto, no caso dos formandos, estas variáveis apresentam média diferente.

Com o objetivo de se analisar a existência de diferenças entre os perfis ocupacionais foi aplicado o teste de Kruskal-Wallis. Desta forma, é possível identificar se para algum dos perfis há diferença em relação aos fatores que dificultam escolha dos formandos como opção ocupacional. Os resultados são apresentados na Tabela 23. 
Tabela 23 - Teste de Kruskal - Wallis para identificar a influência dos fatores que impedem com que crenças coincidam com a opção do aluno por um perfil ocupacional

\begin{tabular}{lc}
\hline Fatores & Valor do teste \\
\hline Recursos financeiros próprios & $0,583^{\mathrm{ns}}$ \\
Acesso a financiamento & $0,292^{\mathrm{ns}}$ \\
Orientação familiar & $2,365^{\mathrm{ns}}$ \\
Treinamento formal deficiente & $0,051^{\mathrm{ns}}$ \\
Política econômica do país & $0,415^{\mathrm{ns}}$ \\
Questões institucionais do país & $2,323^{\mathrm{ns}}$ \\
Acredita que não tem chances de sucesso fazendo o que gostaria & $0,333^{\mathrm{ns}}$ \\
\hline
\end{tabular}

b - significativo a 5\%

c - significativo a $10 \%$

ns - não significativo

Fonte: Resultados da pesquisa

A conclusão é de que não há diferença estatisticamente significativa entre as médias das variáveis considerando-se o perfil ocupacional. Tal resultado difere do resultado da amostra de ingressantes, em que há diferença entre os perfis considerados para as médias das variáveis orientação familiar e auto-confiança no sucesso. Assim, se no caso dos ingressantes pode-se inferir que tanto para funcionários da iniciativa privada quanto para funcionários públicos ou para empresários a percepção destes fatores que impedem que o gosto e a intenção difiram, para os formandos não se pode afirmar o mesmo.

As questões subseqüentes buscam identificar os fatores que influenciam na formação de uma preferência ocupacional. Várias hipóteses discutidas na literatura são verificadas a fim de identificar se aqueles com perfil de funcionário diferem ou não dos com perfil de empresário.

O teste de normalidade de Kolmogorov - Smirnov é apresentado na Tabela 24 para os fatores avaliados na questão 13. Por meio da aplicação de testes paramétricos para a análise visase avaliar se é possível obter resultados confiáveis dos fatores que influenciam na escolha de uma área em que os formandos gostariam de atuar. 
Tabela 24 - Teste de Normalidade de Kolmogorov - Smirnov para os fatores que influenciam nas preferências ocupacionais dos formandos

\begin{tabular}{|c|c|c|c|c|}
\hline \multirow{2}{*}{ Fatores } & \multicolumn{2}{|c|}{ Parâmetros normais (a) } & Teste de & $\begin{array}{c}\text { P-valor do } \\
\text { teste de } \\
\text { Kolmogorov- }\end{array}$ \\
\hline & Média & $\begin{array}{l}\text { Desvio } \\
\text { padrão }\end{array}$ & $\begin{array}{l}\text { Kolmogorov } \\
\text {-Smirnov Z }\end{array}$ & $\begin{array}{c}\text { Kolmogorov- } \\
\text { Smirnov Z }\end{array}$ \\
\hline Maior remuneração da atividade & 7,54 & 2,522 & 2,172 & 0,000 \\
\hline Menos horas trabalhadas & 4,55 & 3,156 & 1,496 & 0,023 \\
\hline Maior estabilidade da atividade & 7,44 & 2,449 & 2,006 & 0,001 \\
\hline Maior status social & 4,54 & 3,053 & 1,937 & 0,001 \\
\hline $\begin{array}{l}\text { Mais prazer proporcionado pelo } \\
\text { cotidiano da atividade }\end{array}$ & 8,60 & 1,983 & 3,367 & 0,000 \\
\hline Pelo incentivo da família & 5,05 & 3,187 & 1,807 & 0,003 \\
\hline Pela orientação do curso universitário & 5,47 & 3,076 & 1,561 & 0,015 \\
\hline Ter participado da empresa junior & 1,97 & 2,883 & 4,049 & 0,000 \\
\hline
\end{tabular}

a - Distribuição testada é normal.

Fonte: Resultados da pesquisa

O resultado do teste de normalidade revela que as variáveis consideradas como influenciadoras da escolha por determinados tipo de ocupação não seguem uma distribuição normal. Desta forma, os testes paramétricos não são apropriados para a análise deste fator. Assim, é apresentado o teste de Friedman a fim de se analisar se há diferença entre as médias das variáveis consideradas. O resultado deste teste, em que $\chi_{c}^{2}=473,925$, indica que existe diferença entre as médias dos fatores com nível de significância de 1\%.

As variáveis consideradas como importantes na decisão de escolha ocupacional não têm impacto igual na escolha. Tal afirmação é feita baseada no resultado do teste de Friedman, assim, aplicou-se o teste de Wilcoxon, pois mesmo não sendo possível concluir qual dos dois fatores avaliados tem maior média, o conhecimento de que as médias em pares são diferentes já é de valia. Na Tabela 25 estão apresentados os resultados deste teste. 
Tabela 25 - Matriz de resultados do teste de Wilcoxon para a diferença entre os fatores que influenciam na decisão de escolha ocupacional

\begin{tabular}{|c|c|c|c|c|c|c|c|c|}
\hline & $\begin{array}{l}\text { Maior } \\
\text { remune- } \\
\text { ração da } \\
\text { atividade }\end{array}$ & $\begin{array}{l}\text { Menos } \\
\text { horas } \\
\text { trabalha- } \\
\text { das } \\
\end{array}$ & $\begin{array}{l}\text { Maior } \\
\text { estabili- } \\
\text { dade da } \\
\text { atividade }\end{array}$ & $\begin{array}{l}\text { Maior } \\
\text { status } \\
\text { social }\end{array}$ & $\begin{array}{l}\text { Prazer } \\
\text { em } \\
\text { atuar }\end{array}$ & $\begin{array}{l}\text { Incen- } \\
\text { tivo da } \\
\text { família }\end{array}$ & $\begin{array}{l}\text { Orientação } \\
\text { do curso } \\
\text { superior } \\
\end{array}$ & $\begin{array}{l}\text { Participar } \\
\text { na empresa } \\
\text { junior }\end{array}$ \\
\hline $\begin{array}{l}\text { Maior } \\
\text { remunera- } \\
\text { ção da ativi } \\
\text { dade }\end{array}$ & & $-8,718^{a}$ & $-0,108^{\mathrm{ns}}$ & $-9,119^{a}$ & $-4,409^{\mathrm{a}}$ & $-7,334^{\mathrm{a}}$ & $-6,200^{\mathrm{a}}$ & $-10,421^{a}$ \\
\hline $\begin{array}{l}\text { Menos } \\
\text { horas } \\
\text { trabalhadas }\end{array}$ & & & $-8,311^{a}$ & $-0,461^{\mathrm{ns}}$ & $-9,301^{a}$ & $-1,634^{\mathrm{ns}}$ & $-2,814^{\mathrm{a}}$ & $-7,141^{\mathrm{a}}$ \\
\hline $\begin{array}{l}\text { Maior } \\
\text { estabili- } \\
\text { dade } \\
\text { da ativi- } \\
\text { dade }\end{array}$ & & & & $-8,196^{a}$ & $-4,915^{\mathrm{a}}$ & $-6,791^{a}$ & $-5,858^{\mathrm{a}}$ & $-10,079^{a}$ \\
\hline $\begin{array}{l}\text { Maior } \\
\text { status } \\
\text { social }\end{array}$ & & & & & $-9,782^{a}$ & $-2,022^{b}$ & $-2,761^{a}$ & $-7,776^{\mathrm{a}}$ \\
\hline $\begin{array}{l}\text { Prazer em } \\
\text { atuar }\end{array}$ & & & & & & $-9,529^{a}$ & $-8,966^{\mathrm{a}}$ & $-10,775^{a}$ \\
\hline $\begin{array}{l}\text { Incentivo } \\
\text { da família }\end{array}$ & & & & & & & $-1,268^{\mathrm{ns}}$ & $-7,631^{\mathrm{a}}$ \\
\hline $\begin{array}{l}\text { Orientaçã } \\
\text { o do curso } \\
\text { superior } \\
\text { Participar } \\
\text { na } \\
\text { empresa } \\
\text { junior }\end{array}$ & & & & & & & & $-8,557^{a}$ \\
\hline $\begin{array}{l}\text { a - signific } \\
\text { b - signific } \\
\text { ns - não si }\end{array}$ & $\begin{array}{l}\text { ativo a } 1 \% \\
\text { ativo a } 5 \% \\
\text { nificativo }\end{array}$ & & & & & & & \\
\hline
\end{tabular}

A análise do teste de Wilcoxon permite concluir que a maior parte dos relacionamentos entre duas variáveis analisadas é estatisticamente significativa a 1\%. Como pares de variáveis que não apresentaram médias diferentes têm-se maior estabilidade versus maior remuneração, maior status social versus menos horas trabalhadas, incentivo familiar versus menos horas trabalhadas e orientação do curso versus incentivo familiar. Este resultado coincide com o relacionamento não significativo entre 2 grupos de variáveis da amostra dos ingressantes. No caso da amostra dos ingressantes não foi estatisticamente significativa a diferença de médias entre estabilidade versus maior remuneração, maior status social versus menos horas trabalhadas. 
A averiguação de diferenças entre as médias dos fatores considerando-se os diferentes perfis ocupacionais é analisada na Tabela 26. Nesta tabela são apresentados os resultados do teste de Kruskal - Wallis. O teste é aplicado tanto para se analisar o gosto por uma ocupação quanto a intenção de atuar em uma atividade.

Tabela 26 - Teste de Kruskal - Wallis para identificar a influência dos fatores na decisão de escolha ocupacional

\begin{tabular}{lcc}
\hline \multirow{2}{*}{ Fatores } & \multicolumn{2}{c}{ Valor do teste } \\
\cline { 2 - 3 } & Gosto & Acredita \\
\hline Maior remuneração da atividade & $2,420^{\mathrm{ns}}$ & $4,314^{\mathrm{ns}}$ \\
Menos horas trabalhadas & $0,183^{\mathrm{ns}}$ & $4,221^{\mathrm{ns}}$ \\
Maior estabilidade da atividade & $1,669^{\mathrm{ns}}$ & $0,042^{\mathrm{ns}}$ \\
Maior status social & $0,881^{\mathrm{ns}}$ & $0,322^{\mathrm{ns}}$ \\
Mais prazer proporcionado pelo cotidiano da atividade & $0,657^{\mathrm{ns}}$ & $4,245^{\mathrm{ns}}$ \\
Pelo incentivo da família & $7,372^{\mathrm{a}}$ & $1,478^{\mathrm{ns}}$ \\
Pela orientação do curso Universitário & $2,739^{\mathrm{ns}}$ & $0,213^{\mathrm{ns}}$ \\
Participado na empresa junior & $0,119^{\mathrm{ns}}$ & $0,964^{\mathrm{ns}}$ \\
\hline
\end{tabular}

a - significativo a $1 \%$

b - significativo a $5 \%$

c - significativo a $10 \%$

ns - não significativo

Fonte: Resultado da pesquisa

Observa-se que todas as variáveis analisadas, com exceção da variável incentivo da família, em relação ao gosto, não apresentam diferença de influência para os perfis analisados. O impacto da variável incentivo da família entre os perfis apresenta uma média estatisticamente significativa com nível de 1\%. Tal resultado é diferente da amostra dos ingressantes, na qual para todas as variáveis consideradas há diferença estatisticamente significativa para a média atribuída, considerando-se o tipo ocupacional, tanto em relação ao gosto quanto à crença por um perfil ocupacional.

A questão 14 visava identificar a influência das pessoas do círculo de convivência dos formandos na preferência por um perfil profissional. A análise destas variáveis segue os moldes 
da demais; primeiro foi aplicado o teste de normalidade de Kolmogorov - Smirnov para verificar se as variáveis seguem uma distribuição normal. Na Tabela 27 estão os resultados que indicam se as variáveis seguem uma distribuição normal.

Tabela 27 - Teste de Normalidade de Kolmogorov - Smirnov para testar a distribuição do grau de influência das pessoas do círculo dos formandos na sua escolha ocupacional

\begin{tabular}{|c|c|c|c|c|}
\hline \multirow[b]{2}{*}{ Fatores } & \multicolumn{2}{|c|}{ Parâmetros normais(a) } & \multirow{2}{*}{$\begin{array}{c}\text { Teste de } \\
\text { Kolmogorov- } \\
\text { Smirnov Z }\end{array}$} & \multirow{2}{*}{$\begin{array}{c}\text { P-valor do teste } \\
\text { de Kolmogorov- } \\
\text { Smirnov Z }\end{array}$} \\
\hline & Média & $\begin{array}{l}\text { Desvio } \\
\text { padrão }\end{array}$ & & \\
\hline Pai & 4,99 & 3,561 & 1,781 & 0,004 \\
\hline Mãe & 4,88 & 3,531 & 1,620 & 0,011 \\
\hline Irmãos & 3,37 & 3,356 & 2,613 & 0,000 \\
\hline Tios & 2,32 & 2,972 & 3,302 & 0,000 \\
\hline Avós & 2,09 & 2,922 & 3,937 & 0,000 \\
\hline Amigos ou colegas & 4,35 & 3,260 & 1,824 & 0,003 \\
\hline Professores & 5,13 & 3,554 & 1,938 & 0,001 \\
\hline
\end{tabular}

Fonte: Resultado da pesquisa

Os resultados do teste de Kolmogorov - Smirnov indicam que a utilização de testes não paramétricos é correta, já que todas as variáveis analisadas nesta questão não seguem distribuição normal, com nível de significância de 1\%. Assim, aplicou-se o teste de Friedman cujo valor do teste, $\chi^{2}{ }_{c}=220,499$ indica, no nível de significância de 1\%, que algum dos elementos do círculo de convivência dos formando afetam de maneira diferente na sua escolha ocupacional.

Pelo resultado do teste de Friedman buscou-se identificar, duas a duas, quais variáveis apresentam diferença de média. Para tal fim, aplicou-se o teste de Wilcoxon, cujos resultados são apresentados na Tabela 28. 
Tabela 28 - Matriz de resultados do teste de Wilcoxon entre o grau de influência das pessoas do círculo dos formandos na sua escolha ocupacional

\begin{tabular}{|c|c|c|c|c|c|c|c|}
\hline & & & & & & Amigos & \\
\hline & Pai & Mãe & Irmãos & Tios & Avós & ou colegas & Professores \\
\hline Pai & & $-0,544^{\mathrm{ns}}$ & $-6,025^{a}$ & $-7,400^{\mathrm{a}}$ & $-8,017^{\mathrm{a}}$ & $-2,022^{a}$ & $-0,314^{\mathrm{ns}}$ \\
\hline Mãe & & & $-5,465^{\mathrm{a}}$ & $-7,243^{\mathrm{a}}$ & $-8,537^{\mathrm{a}}$ & $-2,094^{\mathrm{b}}$ & $-0,789^{\mathrm{ns}}$ \\
\hline Irmãos & & & & $-3,887^{\mathrm{a}}$ & $-4,673^{a}$ & $-3,099^{a}$ & $-4,876^{a}$ \\
\hline Tios & & & & & $-1,113^{\mathrm{ns}}$ & $-6,404^{\mathrm{a}}$ & $-7,498^{\mathrm{a}}$ \\
\hline Avós & & & & & & $-6,982^{a}$ & $-7,506^{\mathrm{a}}$ \\
\hline Amigos ou colegas & & & & & & & $-2,635^{\mathrm{a}}$ \\
\hline Professores & & & & & & & \\
\hline
\end{tabular}

a - significativo a $1 \%$

ns - não significativo

Fonte: Resultado da pesquisa

Os pares de variáveis pai e mãe, professores e pai, professores e mãe, avós e tios, não apresentam diferença de média. Os pares pai e mãe, professores e pai, e professores e mãe também não apresentaram diferença quando analisados para os ingressantes. Assim, tanto para ingressantes quanto para formandos não se pode afirmar que o pai tenha uma influência maior que a mãe, e quando se comparam os pais dos estudantes com professores tem-se o mesmo resultado.

A análise de diferença entre o efeito médio das pessoas do círculo dos formandos na opção ocupacional considerando-se a preferência e a crença em desempenhar atividade de funcionário ou empresarial está apresentada na Tabela 29. 
Tabela 29 - Teste de Kruskal - Wallis para identificar a influência dos fatores que influenciam na decisão de escolha ocupacional

\begin{tabular}{lcc}
\hline \multirow{2}{*}{ Fatores } & \multicolumn{2}{c}{ Valor do teste } \\
\cline { 2 - 3 } & Gosto & Acredita \\
\hline Pai & $4,459^{\mathrm{ns}}$ & $3,522^{\mathrm{ns}}$ \\
Mãe & $1,334^{\mathrm{ns}}$ & $4,133^{\mathrm{ns}}$ \\
Irmãos & $3,041^{\mathrm{ns}}$ & $3,116^{\mathrm{ns}}$ \\
Tios & $2,538^{\mathrm{ns}}$ & $3,040^{\mathrm{ns}}$ \\
Avós & $3,188^{\mathrm{ns}}$ & $3,193^{\mathrm{ns}}$ \\
Amigos ou colegas & $3,940^{\mathrm{ns}}$ & $0,402^{\mathrm{ns}}$ \\
Professores & $1,877^{\mathrm{ns}}$ & $3,593^{\mathrm{ns}}$ \\
\hline
\end{tabular}

a - significativo a $1 \%$

b - significativo a $5 \%$

ns - não significativo

Fonte: Resultado da pesquisa.

O resultado do teste, tanto em relação à preferência quanto à crença, mostrou que nenhuma das pessoas consideradas como possíveis influenciadoras no processo de escolha profissional tem maior participação média com respeito ao tipo de perfil profissional. Este resultado difere do apresentado na amostra dos estudantes ingressantes, em que com relação à preferência, pai, mãe e avós têm maior participação média e também na crença de escolha ocupacional. Ainda na amostra dos ingressantes, pai e avós têm maior influência na crença da escolha da ocupação.

Nas tabelas subseqüentes estão analisados os grupos de variáveis que os estudantes acreditam ser fundamentais ao papel do curso superior como facilitador, para que sua preferência se traduza em intenção. Na Tabela 30 verifica-se através do teste de Kolmogorov - Smirnov se as observações seguem uma distribuição normal. 
Tabela 30 - Teste de Normalidade de Kolmogorov - Smirnov para fatores que os formandos consideram importantes no curso universitário para auxiliá-los na escolha do cargo que desejam desempenhar profissionalmente

\begin{tabular}{|c|c|c|c|c|}
\hline \multirow[b]{3}{*}{ Fatores } & \multicolumn{2}{|c|}{ Parâmetros normais(a) } & \multirow{3}{*}{$\begin{array}{c}\text { Teste de } \\
\text { Kolmogorov- } \\
\text { Smirnov Z }\end{array}$} & \multirow{2}{*}{$\begin{array}{l}\text { P-valor do teste } \\
\text { de Kolmogorov- }\end{array}$} \\
\hline & & Desvio & & \\
\hline & Média & padrão & & Smirnov Z \\
\hline Disciplinas & 5,66 & 2,999 & 1,708 & 0,006 \\
\hline Maior interação entre escola e mercado & 6,50 & 3,215 & 2,332 & 0,000 \\
\hline Maior interação entre professor e aluno & 5,24 & 2,871 & 1,560 & 0,015 \\
\hline $\begin{array}{l}\text { Aulas que mostrassem a aplicabilidade } \\
\text { prática dos conceitos ensinados }\end{array}$ & 6,56 & 3,051 & 2,193 & 0,000 \\
\hline Estágios & 5,93 & 3,276 & 1,643 & 0,009 \\
\hline Orientação do curso & 5,67 & 2,925 & 1,749 & 0,004 \\
\hline Treinamento para lidar com mudanças & 5,53 & 3,219 & 1,793 & 0,003 \\
\hline Treinamento para lidar com risco & 5,86 & 3,306 & 1,974 & 0,001 \\
\hline
\end{tabular}

Fonte: Resultado da pesquisa.

Os resultados do teste de Kolmogorov - Smirnov indicam que as variáveis consideradas não seguem uma distribuição normal. Desta forma, o primeiro teste aplicado é o teste de Friedman, para verificar se, em média, algumas das variáveis diferem em seu grau de ausência. O valor do teste de $\chi^{2}{ }_{\mathrm{c}}=43,835$ indica, no nível de significância de $1 \%$, que ao menos uma das variáveis consideradas faltaram de maneira diferente, tendo um impacto negativo e em maior magnitude no exercício da atividade ocupacional que o formandos gostariam de ocupar.

A partir dos resultados do teste de Friedman, do qual se infere que os fatores avaliados têm impacto diferente, aplica-se o teste de Wilcoxon. Assim, é possível analisar duas a duas variáveis quais grupos apresentam diferença de média ou não. Na Tabela 31 é mostrado o resultado do teste de Wilcoxon. 
Tabela 31 - Matriz de resultados do teste de Wilcoxon para fatores que os formandos consideram importantes no curso universitário para auxiliá-los no desempenho profissional

\begin{tabular}{|c|c|c|c|c|c|c|c|c|}
\hline & $\begin{array}{l}\text { Discipli- } \\
\text { nas }\end{array}$ & $\begin{array}{l}\text { Maior } \\
\text { interação } \\
\text { entre } \\
\text { escola e } \\
\text { mercado }\end{array}$ & $\begin{array}{l}\text { Maior } \\
\text { interação } \\
\text { entre } \\
\text { professor } \\
\text { e aluno }\end{array}$ & $\begin{array}{l}\text { Aulas } \\
\text { práticas } \\
\text { sobre os } \\
\text { conceitos } \\
\text { ensinados }\end{array}$ & Estágios & $\begin{array}{l}\text { Orientação } \\
\text { do } \\
\text { curso }\end{array}$ & $\begin{array}{l}\text { Treina- } \\
\text { mento } \\
\text { para lidar } \\
\text { com } \\
\text { mudan- } \\
\text { ças }\end{array}$ & $\begin{array}{l}\text { Treina- } \\
\text { mento } \\
\text { para lidar } \\
\text { com } \\
\text { risco }\end{array}$ \\
\hline $\begin{array}{l}\text { Disciplinas } \\
\text { Maior } \\
\text { Interação } \\
\text { entre escola e } \\
\text { mercado }\end{array}$ & & $-3,553^{a}$ & $\begin{array}{l}-1,183^{\mathrm{ns}} \\
-4,720^{\mathrm{ns}}\end{array}$ & $\begin{array}{l}-3,253^{\mathrm{a}} \\
-0,198^{\mathrm{ns}}\end{array}$ & $\begin{array}{l}-0,973^{\mathrm{ns}} \\
-2,126^{\mathrm{b}}\end{array}$ & $\begin{array}{l}-0,300^{\text {ns }} \\
-3,077^{\mathrm{a}}\end{array}$ & $\begin{array}{l}-0,664^{\mathrm{ns}} \\
-3,154^{\mathrm{a}}\end{array}$ & $\begin{array}{l}-0,375^{\mathrm{ns}} \\
-2,178^{\mathrm{b}}\end{array}$ \\
\hline $\begin{array}{l}\text { Maior } \\
\text { interação entre } \\
\text { professor e aluno }\end{array}$ & & & & $-5,062^{a}$ & $-2,374^{b}$ & $-1,533^{\mathrm{ns}}$ & $-0,635^{\mathrm{ns}}$ & $-2,063^{b}$ \\
\hline $\begin{array}{l}\text { Aulas } \\
\text { práticas sobre os } \\
\text { conceitos ensinados }\end{array}$ & & & & & $-2,444^{\mathrm{b}}$ & $-3,593^{a}$ & $-3,929^{a}$ & $-2,478^{b}$ \\
\hline Estágios & & & & & & $-1,385^{\mathrm{ns}}$ & $-1,014^{\mathrm{ns}}$ & $-0,005^{\text {ns }}$ \\
\hline $\begin{array}{l}\text { Orientação do curso } \\
\text { Treinamento para } \\
\text { lidar com mudanças } \\
\text { Treinamento para } \\
\text { lidar com risco }\end{array}$ & & & & & & & $-0,256^{\mathrm{ns}}$ & $\begin{array}{l}-0,916^{\mathrm{ns}} \\
-2,572^{\mathrm{a}}\end{array}$ \\
\hline $\begin{array}{l}\text { a - significativo a } \\
\text { b - significativo a } \\
\text { ns - não significat } \\
\text { Fonte: Resultado da }\end{array}$ & $\begin{array}{l}1 \% \\
5 \% \\
\text { ivo } \\
\end{array}$ & & & & & & & \\
\hline
\end{tabular}

O número de relacionamentos cuja diferença entre as médias não é estatisticamente significante foi igual 14. Assim, diversos relacionamentos avaliados não foram considerados relevantes pelos estudantes e não faltaram em magnitude média diferente.

O teste de Kruskal - Wallis identificará se para os perfis considerados os fatores influenciaram, em média, diferentemente. Cabe salientar que nesta questão a análise foi feita somente para a preferência, uma vez que buscou-se conhecer se há divergência na magnitude do impacto entre a preferência pelos perfis. Os resultados deste teste são apresentados na Tabela 32. 
Tabela 32 - Teste de Kruskal - Wallis para fatores que os formandos consideram importantes no curso universitário para auxiliá-los na escolha do cargo que desejam desempenhar profissionalmente

\begin{tabular}{lc}
\hline \multicolumn{1}{c}{ Fatores } & Valor do teste \\
\hline Maior interação entre escola e mercado & $1,988^{\mathrm{ns}}$ \\
Maior interação entre professor e aluno & $1,049^{\mathrm{ns}}$ \\
Aulas práticas dos conceitos ensinados & $1,356^{\mathrm{ns}}$ \\
Estágios & $2,465^{\mathrm{ns}}$ \\
Orientação do curso & $4,110^{\mathrm{ns}}$ \\
Treinamento para lidar com mudanças & $0,169^{\mathrm{ns}}$ \\
Treinamento para lidar com risco & $1,632^{\mathrm{ns}}$ \\
\hline
\end{tabular}

a - significativo a $1 \%$

b - significativo a $5 \%$

c - significativo a $10 \%$

ns - não significativo

Fonte: Resultado da pesquisa

Os resultados apresentados pelo teste indicam que entre os perfis não há influência, em média, estatisticamente diferente entre os perfis considerados. Desta forma, tanto os que gostam de ser funcionários da iniciativa privada, como os que gostam de ser funcionário público, quanto os que desejam ser empresário consideram que estes fatores não foram relevantes em mesma magnitude.

\subsection{Análise fatorial aplicada aos ingressantes}

A análise fatorial tem como um dos objetivos a redução da dimensionalidade dos dados por meio da identificação de um pequeno número de fatores que explicam significativa parcela da variância observada. Assim, a utilização da análise fatorial possibilitará a verificação de quais variáveis estão relacionadas entre si na formação de um fator que explica a preferência por um perfil ocupacional. O método de analise fatorial permite que se organize a forma como os estudantes interpretam a importância dos fatores para a formação de sua preferência. Em 
consonância com este objetivo utilizou-se de análise fatorial para tentar agrupar em fatores as catorze variáveis que contam nas questões 13 e 14, que inquiriam sobre a influência de diversas variáveis e de pessoas do círculo social do estudante na sua preferência por uma atividade ocupacional. A incorporação de tais variáveis se deu em virtude de na literatura serem assinaladas como importantes no processo de escolha ocupacional, além da escolha por determinado tipo de ocupação ser passível de sofrer influência destas variáveis.

A extração das cargas fatoriais foi realizada pelo método de componentes principais, em razão de este método não ter como pressuposição que as variáveis estejam normalmente distribuídas. A verificação de ajustamento à distribuição normal das variáveis foi discutida quando se testou a adequação da aplicação de métodos não paramétricos. A rotação ortogonal foi realizada pelo método de rotação ortogonal Varimax, que minimiza o número de variáveis em cada fator.

Na literatura é indicada a inspeção da matriz de anti-imagem e das comunalidades após a extração de fatores, a fim de se optar por eliminar variáveis. A averiguação da matriz de antiimagem não sugeriu a retirada de nenhuma variável, dado o alto valor das medidas de adequação da amostra. No entanto, a análise das comunalidades de duas variáveis, irmão e maior status social, têm uma relação mediana com os fatores extraídos. A variância total da variável irmão explicada pelos fatores é de 0,434, enquanto da variável maior status social é de 0,467. Tais resultados levaram à retirada das variáveis: irmãos e maior status social. Portanto, no modelo fatorial a ser discutido foram incorporadas doze variáveis.

Com vistas de avaliar a aderência do ajustamento das informações ao modelo fatorial obtido, apresenta-se o coeficiente de KMO. O coeficiente de KMO é igual a 0,73, o que é considerado pela literatura estatística como indicativo médio de adequação dos dados ao tratamento da análise fatorial. Outro teste apresentado é o de esfericidade de Bartlett, o resultado deste teste indica que, no nível de significância de $1 \%$, pode-se concluir que a aplicação de análise fatorial para as variáveis é útil. Em síntese, os resultados dos testes realizados permitiram concluir que a amostra de dados é passível de ser analisada pela técnica de análise fatorial.

A solução do modelo fatorial é apresentada na Tabela 33, em que se observa que quatro fatores apresentaram raíz característica superior à unidade. Estes fatores explicam em torno de 64,64\% da variância dos dados. Observa-se que após a rotação dos fatores ocorreu uma redistribuição de magnitude significativa entre os fatores. 
Tabela 33 - Variância explicada pelos fatores na solução inicial e na solução rotacionada

\begin{tabular}{|c|c|c|c|c|c|c|}
\hline \multirow[b]{3}{*}{ Fatores } & \multicolumn{3}{|c|}{ Solução inicial } & \multicolumn{3}{|c|}{ Solução após rotação } \\
\hline & Raiz & $\%$ da & $\%$ & Raiz & $\%$ da & $\%$ \\
\hline & característica & Variância & Acumulada & característica & Variância & Acumulada \\
\hline 1 & 3,516 & 29,301 & 29,301 & 2,333 & 19,442 & 19,442 \\
\hline 2 & 1,800 & 15,004 & 44,305 & 2,204 & 18,367 & 37,809 \\
\hline 3 & 1,253 & 10,440 & 54,745 & 1,992 & 16,600 & 54,409 \\
\hline 4 & 1,187 & 9,893 & 64,638 & 1,227 & 10,228 & 64,638 \\
\hline 5 & 0,957 & 7,972 & 72,610 & & & \\
\hline 6 & 0,732 & 6,101 & 78,711 & & & \\
\hline 7 & 0,591 & 4,929 & 83,640 & & & \\
\hline 8 & 0,526 & 4,380 & 88,020 & & & \\
\hline 9 & 0,413 & 3,444 & 91,464 & & & \\
\hline 10 & 0,379 & 3,161 & 94,626 & & & \\
\hline 11 & 0,348 & 2,899 & 97,524 & & & \\
\hline 12 & 0,297 & 2,476 & 100,000 & & & \\
\hline
\end{tabular}

Fonte: Resultado da pesquisa

A rotação dos fatores visa identificar em qual fator a variável estará contida, assim, na Tabela 34 são apresentadas as variáveis e as cargas fatoriais correspondentes, após a rotação dos fatores pelo método Varimax. 
Tabela 34 - Determinação das variáveis componentes em cada fator após a rotação pelo método Varimax

\begin{tabular}{lcccc}
\hline \multicolumn{1}{c}{ Variável } & \multicolumn{4}{c}{ Fator } \\
\cline { 2 - 5 } & 1 & 2 & 3 & 4 \\
\hline Tios & $\mathbf{0 , 7 2 3}$ & 0,202 & 0,062 & $-0,036$ \\
Avos & $\mathbf{0 , 6 5 8}$ & 0,298 & 0,072 & $-0,082$ \\
Amigos ou colegas & $\mathbf{0 , 7 4 5}$ & 0,018 & 0,091 & 0,121 \\
Professores & $\mathbf{0 , 7 5 8}$ & 0,014 & $-0,006$ & 0,071 \\
Pelo incentivo da família & 0,016 & $\mathbf{0 , 8 0 3}$ & 0,170 & 0,204 \\
Pela orientação do curso universitário & 0,038 & $\mathbf{0 , 6 1 3}$ & 0,239 & 0,424 \\
Pai & 0,320 & $\mathbf{0 , 6 9 6}$ & 0,041 & $-0,324$ \\
Mãe & 0,344 & $\mathbf{0 , 7 1 2}$ & 0,084 & $-0,293$ \\
Maior remuneração da atividade & 0,093 & 0,134 & $\mathbf{0 , 8 3 2}$ & $-0,116$ \\
Menos horas trabalhadas & 0,084 & 0,032 & $\mathbf{0 , 7 8 1}$ & $-0,099$ \\
Maior estabilidade da atividade & 0,005 & 0,206 & $\mathbf{0 , 7 5 7}$ & 0,263 \\
Mais prazer proporcionado pelo cotidiano da atividade & 0,099 & $-0,028$ & $-0,058$ & $\mathbf{0 , 8 3 4}$ \\
\hline
\end{tabular}

Fonte: Resultado da pesquisa

A consideração na elaboração do questionário de que existiam dois blocos de variáveis como possíveis fatores explicativos da escolha ocupacional não foi verificada. Estes dois grupos podem ser classificados como fatores de ambiente e fatores de influência de pessoas do círculo social dos estudantes.

O modelo fatorial sugeriu o agrupamento em quatro fatores que explicam a formação da preferência por uma atividade profissional. No primeiro fator, 19,4\% da variância é explicada, e como variáveis estão os componentes: tios, avós, amigos e colegas e professores. Dadas as variáveis que integram este fator, este foi denominado globalmente como influências sociais.

O segundo fator é composto pelas variáveis: pai, mãe, incentivo familiar e orientação do curso, sendo um indicador da influência do incentivo ao desempenho de uma atividade profissional. Neste fator, em torno de 18,4\% da variância dos dados é explicada. Observa-se que há diferenciação na aglomeração dos fatores que visam refletir a influência das pessoas do círculo social dos ingressantes. O segundo fator agrupa pessoas com relacionamento direto com os 
ingressantes. Enquanto o primeiro fator é composto pelas pessoas com relacionamento indireto aos estudantes; o segundo é nomeado como incentivo.

As variáveis associadas à remuneração, estabilidade e horas trabalhadas na atividade formam um fator. Este pode ser denominado como fator retorno econômico e capta 16,6\% da variância dos dados. Tal denominação é fundamentada na consideração de que todas as variáveis estão relacionadas a questões econômicas, observando-se a análise da relação risco-retorno financeiro da ocupação. Por último, tem-se o fator prazer constituído de uma variável, o maior prazer proporcionado pelo cotidiano da atividade; em torno de 10,2\% da variância dos dados é explicada por este fator. Observa-se que a afirmação de King (1974) de que a influência na escolha ocupacional os fatores família e forças de mercado são independentes é verificada neste estudo.

As variáveis utilizadas nesta análise fatorial são variáveis em escala, assim, conforme sugerido na literatura, é necessária a aplicação do teste de consistência interna dos fatores. A necessidade de se avaliar a consistência interna dos fatores se dá porque a divergência das respostas pode ocorrer em razão de confusões e interpretações errôneas e não de visões diferentes. O teste aplicado foi o alfa de Crobach, o mais utilizado para se avaliar a consistência interna. Esta medida varia de zero a um, sendo quão próximo de um melhor indicador de consistência interna.

O valor do teste de alfa de Crobach para os fatores influência social, incentivo familiar e retorno econômico indicaram que a consistência interna dos fatores é aceitável. Estes valores foram iguais a $0,73,0,74$ e 0,73 , respectivamente. Cabe salientar que ao fator prazer não foi aplicado ao teste, dado que é formado por uma variável. As correlações entre as variáveis que constituem os fatores são moderadas, e atribuindo-se o grau de importância pela média do fator tem-se que o fator mais importante é o retorno econômico, seguido por incentivo e influência social.

Os valores do teste de alfa de Crobach indicaram que os fatores apresentam uma consistência interna aceitável. Desta forma, a construção de índices para realizar outras análises quantitativas, como modelos econométricos, não é aconselhável, pois os valores do teste foram inferiores a 0,8. Assim, a análise de regressão não foi realizada. 


\subsection{Análise fatorial aplicado aos formandos}

A finalidade da utilização do método de análise fatorial é agrupar as variáveis consideradas como explicativas na determinação da preferência ocupacional, assim, podendo-se proceder a análises a partir de um número reduzido de fatores que explicam uma significativa parcela da variância observada. Um aspecto relevante associado à análise fatorial é a possibilidade de organizar as impressões dos estudantes acerca da importância dos fatores considerados. Desta forma, as quinze variáveis sobre os fatores que influenciam na formação da preferência ocupacional que contam no questionário serão agrupadas no menor número de fatores possíveis.

Os procedimentos adotados na análise fatorial da amostra de ingressantes foram também adotados para a análise fatorial da amostra de formando. Desta forma, dispensam-se mais explicações como a de que a extração das cargas fatoriais foi realizada pelo método de componentes principais.

A decisão de excluir alguma variável da análise fatorial se dá pela inspeção da matriz de anti-imagem e das comunalidades. A análise tanto da matriz de anti-imagem quanto das comunalidades não sugere que seja excluída nenhuma variável do modelo. Desta forma, no modelo fatorial a ser discutido foram incorporadas quinze variáveis.

A aderência do ajustamento das informações ao modelo fatorial obtido é avaliada pelo coeficiente de KMO. O coeficiente de KMO é igual a 0,74, assim, tem-se uma adequação mediana dos dados ao tratamento da análise fatorial. É recomendada também a inspeção do teste de esfericidade de Bartlett, cujo resultado indica que no nível de significância de 1\%, pode-se inferir que na aplicação de análise fatorial as variáveis são úteis. Resumindo, os resultados dos testes realizados permitiram concluir que a amostra de dados é passível de ser analisada pela técnica de análise fatorial.

A solução do modelo fatorial está apresentada na Tabela 35, em que se observa que cinco fatores apresentaram raíz característica superior à unidade. Estes fatores explicam em torno de 64,82\% da variância dos dados. Comparando com os resultados da análise fatorial aplicada à amostra dos ingressantes tem-se o aumento do número de fatores e um pequeno aumento de explicação da variância dos dados, em torno de 0,18 pontos percentuais. Observa-se que após a rotação dos fatores ocorreu uma redistribuição de magnitude significativa entre os fatores. 
Tabela 35 - Variância explicada pelos fatores na solução inicial e na solução rotacionada

\begin{tabular}{|c|c|c|c|c|c|c|}
\hline \multirow[b]{3}{*}{ Fatores } & \multicolumn{3}{|c|}{ Solução inicial } & \multicolumn{3}{|c|}{ Solução após rotação } \\
\hline & Raiz & $\%$ da & $\%$ & Raiz & $\%$ da & $\%$ \\
\hline & característica & Variância & Acumulada & característica & Variância & Acumulada \\
\hline 1 & 4,040 & 26,933 & 26,933 & 3,278 & 21,853 & 21,853 \\
\hline 2 & 2,024 & 13,492 & 40,426 & 1,760 & 11,732 & 33,586 \\
\hline 3 & 1,378 & 9,185 & 49,611 & 1,725 & 11,498 & 45,084 \\
\hline 4 & 1,265 & 8,436 & 58,047 & 1,623 & 10,819 & 55,903 \\
\hline 5 & 1,016 & 6,775 & 64,822 & 1,338 & 8,919 & 64,822 \\
\hline 6 & 0,973 & 6,484 & 71,306 & & & \\
\hline 7 & 0,734 & 4,891 & 76,197 & & & \\
\hline 8 & 0,671 & 4,471 & 80,668 & & & \\
\hline 9 & 0,592 & 3,947 & 84,614 & & & \\
\hline 10 & 0,519 & 3,457 & 88,071 & & & \\
\hline 11 & 0,458 & 3,053 & 91,125 & & & \\
\hline 12 & 0,438 & 2,919 & 94,044 & & & \\
\hline 13 & 0,368 & 2,452 & 96,496 & & & \\
\hline 14 & 0,283 & 1,886 & 98,382 & & & \\
\hline 15 & 0,243 & 1,618 & 100,000 & & & \\
\hline
\end{tabular}

Fonte: Resultado da pesquisa.

A rotação dos fatores visa identificar que variáveis fazem parte dos fatores da solução. Na Tabela 36 são apresentadas as variáveis e as cargas fatoriais correspondentes após a rotação dos fatores pelo método Varimax, que foram obtidas com 7 iterações. 
Tabela 36 - Determinação das variáveis componentes em cada fator após a rotação pelo método Varimax

\begin{tabular}{lccccc}
\hline Variável & \multicolumn{5}{c}{ Fator } \\
\cline { 2 - 6 } & 1 & 2 & 3 & 4 & 5 \\
\hline Pai & $\mathbf{0 , 7 5 2}$ & 0,170 & 0,029 & 0,229 & $-0,236$ \\
Mãe & $\mathbf{0 , 7 8 3}$ & 0,247 & 0,022 & 0,172 & $-0,146$ \\
Irmãos & $\mathbf{0 , 7 5 3}$ & 0,023 & 0,128 & 0,142 & 0,004 \\
Tios & $\mathbf{0 , 6 8 6}$ & 0,079 & 0,000 & $-0,050$ & 0,453 \\
Avos & $\mathbf{0 , 7 3 8}$ & 0,017 & 0,040 & $-0,078$ & 0,418 \\
Amigos ou colegas & $\mathbf{0 , 5 5 2}$ & 0,311 & $-0,065$ & $-0,327$ & $-0,033$ \\
Pelo incentivo da família & 0,341 & $\mathbf{0 , 5 1 1}$ & 0,111 & 0,375 & $-0,014$ \\
Pela orientação do curso universitário & 0,012 & $\mathbf{0 , 8 0 4}$ & 0,033 & 0,137 & 0,153 \\
Professores do curso superior & 0,268 & $\mathbf{0 , 7 2 7}$ & 0,055 & $-0,144$ & 0,004 \\
Maior remuneração da atividade & 0,056 & 0,033 & $\mathbf{0 , 7 5 5}$ & 0,324 & 0,151 \\
Maior estabilidade da atividade & 0,028 & $-0,055$ & $\mathbf{0 , 7 5 9}$ & 0,285 & $-0,144$ \\
Mais prazer proporcionado pelo cotidiano & & & & & \\
da atividade & 0,054 & 0,230 & $\mathbf{0 , 6 8 7}$ & $-0,365$ & $-0,027$ \\
Menos horas trabalhadas & 0,111 & 0,002 & 0,131 & $\mathbf{0 , 7 4 4}$ & 0,030 \\
Maior status social & 0,069 & 0,262 & 0,216 & $\mathbf{0 , 5 7 9}$ & 0,410 \\
Ter participado na empresa junior & $-0,035$ & 0,076 & $-0,051$ & 0,130 & $\mathbf{0 , 8 0 2}$ \\
\hline
\end{tabular}

Fonte: Resultado da pesquisa

Verifica-se que assim como na amostra dos ingressantes, a consideração na elaboração do questionário de que existiam dois blocos de variáveis como possíveis fatores explicativos da escolha ocupacional não é observada na solução da análise fatorial. Os grupos podem ser classificados como fatores de ambiente e fatores de influência de pessoas do círculo social dos estudantes.

O modelo fatorial sugeriu o agrupamento em cinco fatores que explicam a preferência por uma atividade profissional. O primeiro fator explica em torno de 21,8\% da variância e é composto pelas variáveis: pai, mãe, irmãos, tios, avós e colegas. Comparando com o resultado da 
análise fatorial da amostra de ingressantes observa-se que para os formandos, pai e mãe passam a fazer parte deste fator e professores são excluídos. Em razão das variáveis que integram este fator, mesmo divergindo do verificado na análise dos ingressantes continua-se a denominá-lo de influências sociais.

O segundo fator é composto pelas variáveis: incentivo familiar, orientação do curso e professor. Observa-se que em comparação à amostra de ingressantes, há uma troca entre estes fatores e o fator influências sociais. As variáveis pai e mãe faziam parte deste fator no caso dos ingressantes, e para os formandos, estas variáveis fazem parte do fator influências sociais. Outra modificação é a variável professores, que compunha o fator influências sociais no caso dos ingressantes; para os formandos, esta variável compõe o segundo fator. O segundo fator, assim como no caso dos ingressantes, é denominado de incentivo, por ser um indicador da influência de uma orientação para a formação de um perfil ocupacional. A variância explicada pelo fator incentivo é em torno de 11,7\%, inferior ao caso dos ingressantes, em que explica 18,4\%. Observa-se que para os ingressantes há um indicativo de diferenciação na aglomeração dos fatores que refletem a influência das pessoas do círculo social. A diferenciação poderia ser entendida como agrupar pessoas do relacionamento direto e indireto dos estudantes. No entanto, com respeito aos formandos, não se pode defender o mesmo argumento, já que pai e mãe passam a integrar o fator influência social. Uma possível explicação é a faixa etária dos estudantes, quando entram na universidade estão no final da adolescência, fase em que os pais ainda têm maior influência. Os estudantes que estão terminando o curso superior são jovens adultos, cuja influência dos pais é menor na formação de sua preferência. Outro aspecto também é o deslocamento dos professores, que passam a explicar a formação da preferência juntamente com a orientação do curso.

As observações associadas à remuneração, estabilidade e ao prazer proporcionados pelo cotidiano da atividade explicam juntos em torno de 11,5\% a variância dos dados. O fator que estas formam é denominado de retorno econômico, mas em comparação ao dos ingressantes, nota-se que no caso dos formandos há incorporação neste fator do prazer proporcionado pelo cotidiano da atividade e exclusão da variável menos horas trabalhadas. Defende-se que o fator reflete uma análise de risco retorno em que o agente considera também o prazer como um retorno associado ao exercício da ocupação profissional. 
O quarto fator agrupa as variáveis menos horas trabalhadas e maior status social, sendo a variância dos dados explicada por este fator igual a 10,8\%. Comparando com a análise fatorial para a amostra de ingressantes, nota-se que a variável maior status social foi excluída da análise em razão da inspeção das comunalidades. Assim, a variável maior status social não foi incorporada na solução fatorial da amostra dos ingressantes. Este fator é denominado de características e a sua interpretação é que os formandos, ao escolherem um perfil empresarial, são influenciados por uma análise custo beneficio. O último fator é composto por uma única variável, a participação na empresa júnior e explica 8,9\% da variância dos dados. Este fator é denominado de experiência. Assim, como na amostra dos ingressantes, observa-se que a afirmação de King (1974) acerca da independência dos aspectos referentes a mercado e variáveis familiares foi verificada.

As variáveis utilizadas nesta análise fatorial foram mensuradas em escala, e segundo a literatura, é prudente proceder ao teste de consistência interna dos fatores. A avaliação da consistência interna dos fatores é feita porque a variância das observações pode ocorrer em razão de confusões e interpretações errôneas e não de visões diferentes. O teste aplicado foi o alfa de Crobach, o mais utilizado para se avaliar a consistência interna. Esta medida varia de zero a um, sendo que quão próximo de um seria melhor indicador de consistência interna.

O valor do teste de alfa de Crobach para os fatores, com exceção do fator círculo social não indicou boa consistência interna. O fator círculo social apresenta um coeficiente de alfa de Crobach igual a 0,83. Os demais fatores, incentivo, retorno econômico e característica, apresentaram coeficiente de 0,60, 0,69 e 0,49, respectivamente. Estes valores são inferiores aos apresentados pelos fatores extraídos da amostra de ingressantes, não podendo nem ser considerados como razoáveis. Cabe salientar que ao fator experiência não foi aplicado o teste, já que é formado por uma variável. As correlações entre as variáveis que constituem os fatores são moderadas e, atribuindo-se o grau de importância pela média do fator, tem-se que o fator mais importante é o retorno econômico, seguido por incentivo, característica e influência social. Este resultado é similar ao da amostra dos ingressantes, com exceção do fator característica. Desta forma, assim como na amostra dos ingressantes, não é apropriada a construção de índices e a execução de outras análises quantitativas com os índices construídos a partir dos fatores. 


\subsection{Empecilhos Contextuais e Expectativas e Facilitadores no curso superior para desempenhar funções empresariais}

O questionário aplicado continha duas questões que visavam identificar variáveis que impedem ou facilitam a preferência por uma carreira. Os testes estatísticos indicaram para algumas variáveis que havia diferença de impacto, em média, para cada perfil ocupacional. No entanto, por tais testes não é possível afirmar para qual grupo a magnitude do impacto é maior. Com o objetivo de analisar a resposta do grupo com preferência por atividades empresariais, neste item é apresentada a freqüência dos valores respondidos pelos estudantes ingressantes e formandos, com respeito a estas duas questões.

A primeira questão avaliada trata de fatores que podem ser empecilhos para que a preferência seja igual à crença dos estudantes quanto ao perfil ocupacional desejado. Esta questão contém algumas variáveis e o estudante assinalava qual o grau em que a variável representa um limitante. A escala utilizada é de 0 a 10, em que o valor zero correspondente à variável não limita em nenhum aspecto que a preferência seja igual à crença, e o valor 10 refere-se à visão de que o fator é totalmente limitante para que a preferência possa ser uma intenção. Na Tabela 37 é apresentada a freqüência das respostas dos estudantes ingressantes.

Tabela 37 - Freqüência dos valores dos fatores assinalados pelos estudantes ingressantes como limitadores da preferência por uma carreira

\begin{tabular}{lrrrrrrrrrrrr}
\hline & \multicolumn{1}{c}{ Valores } \\
\cline { 2 - 10 } & 0 & 1 & 2 & 3 & 4 & 5 & 6 & 7 & 8 & 9 & 10 \\
\hline Recursos financeiros próprios & 3 & 1 & 3 & 5 & 3 & 19 & 0 & 11 & 6 & 7 & 11 \\
Acesso a financiamento & 2 & 6 & 6 & 4 & 4 & 19 & 4 & 9 & 8 & 4 & 2 \\
Orientação familiar & 24 & 15 & 2 & 1 & 3 & 10 & 4 & 1 & 5 & 2 & 1 \\
Treinamento formal deficiente & 17 & 7 & 5 & 4 & 7 & 5 & 8 & 4 & 4 & 4 & 3 \\
Política econômica do país & 4 & 5 & 4 & 7 & 4 & 9 & 4 & 10 & 9 & 9 & 4 \\
Questões institucionais do país & 5 & 5 & 5 & 8 & 6 & 12 & 4 & 10 & 13 & 1 & 0 \\
Acredita que não tem chances de sucesso fazendo & 28 & 10 & 4 & 6 & 5 & 8 & 3 & 1 & 0 & 2 & 2 \\
o que gostaria & & & & & & & & & & & \\
\hline
\end{tabular}

Fonte: Resultado da pesquisa 
A análise da freqüência das respostas dos alunos ingressantes indica que os fatores que foram considerados mais freqüentemente como muito limitantes são: recursos financeiros próprios, acesso a financiamento, política econômica do país e questões institucionais do país. Com relação às variáveis orientação familiar, treinamento formal deficiente e acredita que não tem chances de sucesso fazendo o que gostaria, a freqüência dos valores atribuídos é, em geral, os valores menores da escala. A maior parcela dos estudantes tem autoconfiança de que terão chances de sucesso. Observa-se um percentual que assina medianamente com freqüência as questões.

A questão que indagava os fatores que impediam com que a preferência e a crença fossem iguais foi respondida pelos formandos também. A freqüência dos valores das respostas dos estudantes formandos está apresentada na Tabela 38.

Tabela 38 - Freqüência dos valores dos fatores assinalados pelos estudantes ingressantes como limitadores da preferência por uma carreira

\begin{tabular}{|c|c|c|c|c|c|c|c|c|c|c|c|}
\hline \multirow[b]{2}{*}{ Fator } & \multicolumn{11}{|c|}{ Valores } \\
\hline & 0 & 1 & 2 & 3 & 4 & 5 & 6 & 7 & 8 & 9 & 10 \\
\hline Recursos financeiros próprios & 6 & 4 & 2 & 1 & 0 & 3 & 1 & 4 & 2 & 6 & 23 \\
\hline Acesso a financiamento & 6 & 4 & 4 & 2 & 4 & 8 & 1 & 7 & 5 & 7 & 4 \\
\hline Orientação familiar & 21 & 8 & 5 & 3 & 4 & 3 & 2 & 0 & 2 & 1 & 3 \\
\hline Treinamento formal deficiente & 14 & 6 & 14 & 6 & 4 & 11 & 0 & 5 & 2 & 1 & 0 \\
\hline Política econômica do país & 3 & 1 & 1 & 3 & 1 & 13 & 6 & 4 & 10 & 5 & 5 \\
\hline Questões institucionais do país & 3 & 3 & 2 & 2 & 5 & 15 & 2 & 6 & 8 & 4 & 2 \\
\hline $\begin{array}{l}\text { Acredita que não tem chances de sucesso fazendo o } \\
\text { que gostaria }\end{array}$ & 29 & 3 & 7 & 2 & 3 & 3 & 1 & 0 & 1 & 1 & 2 \\
\hline
\end{tabular}

Fonte: Resultado da pesquisa

Os valores tidos como muito limitantes foram assinalados para as variáveis recursos financeiros próprios e acesso a financiamento. Com relação à formação formal deficiente os ingressantes não consideram que seria um fator com alto grau de limitação. Observa-se que os valores indicados para a variável orientação familiar têm também comportamento semelhante à formação formal deficiente. Observa-se que os estudantes têm alto grau de autoconfiança em relação a suas possibilidades de fazer sucesso. Comparando-se as tabelas de freqüência dos 
ingressantes e formandos observa-se que não há mudança de visão quanto ao grau em que os fatores limitam. Os fatores que podem ter um poder de limitação baixo pelos ingressantes também foram considerados pelos formandos, evidentemente, pode haver divergência na freqüência da nota atribuída.

A segunda questão a ser analisada neste item está relacionada com as expectativas dos ingressantes quanto a fatores que acreditam possam auxiliá-los no desenvolvimento da atividade que lhes agrada. No questionário que foi aplicado aos formandos esta questão foi modificada para fatores que no curso universitário poderiam auxiliá-los no desempenho da atividade que lhes agradava. As questões são avaliadas por meio de uma escala de 0 a 10, em que o valor zero indica que o fator não auxiliou e o valor dez que auxilia totalmente. Cabe salientar que como o foco da pesquisa é entender os determinantes na preferência por uma carreira, aqui só é apresentada a visão dos estudantes com perfil empresarial. Na Tabela 39 é apresentada a freqüência dos valores assinalados pelos estudantes ingressantes.

Tabela 39 - Freqüência dos valores assinalados pelos estudantes ingressantes de perfil empresarial dos fatores que esperam que facilitem com que o gosto se torne em intenção

\begin{tabular}{|c|c|c|c|c|c|c|c|c|c|c|c|}
\hline \multirow[b]{2}{*}{ Fator } & \multicolumn{11}{|c|}{ Valores } \\
\hline & 0 & 1 & 2 & 3 & 4 & 5 & 6 & 7 & 8 & 9 & 10 \\
\hline Interação entre escola e mercado & 2 & 0 & 1 & 1 & 0 & 7 & 8 & 8 & 13 & 13 & 17 \\
\hline Interação entre professor e aluno & 1 & 0 & 0 & 1 & 1 & 7 & 8 & 9 & 11 & 19 & 13 \\
\hline $\begin{array}{l}\text { Aulas que mostrem a aplicabilidade prática dos } \\
\text { conceitos ensinados }\end{array}$ & 1 & 1 & 1 & 1 & 0 & 3 & 3 & 5 & 12 & 18 & 25 \\
\hline Estágios & 1 & 0 & 0 & 1 & 1 & 7 & 6 & 18 & 16 & 13 & 25 \\
\hline Orientação do curso & 0 & 0 & 0 & 1 & 1 & 7 & 6 & 18 & 16 & 13 & 8 \\
\hline Treinamento para lidar com mudanças & 1 & 1 & 1 & 1 & 6 & 5 & 5 & 9 & 15 & 11 & 15 \\
\hline Treinamento para lidar com risco & 2 & 0 & 0 & 2 & 6 & 5 & 0 & 6 & 17 & 16 & 16 \\
\hline
\end{tabular}

Fonte: Resultado da pesquisa

Os resultados com relação à amostra de ingressantes indicam que os aspectos assinalados, em geral, foram considerados como relevantes para que, no futuro, tenham a intenção de atuar 
como empresários. Com relação aos empecilhos observa-se que uma significativa parcela tendeu a responder os valores medianos, mas para os fatores que facilitariam não se verifica este comportamento. Os escores acima de 8 receberam uma grande freqüência de respostas, assim, os estudantes ingressantes têm expectativa de que no curso superior receberão um treinamento com estes itens.

Os resultados referentes à amostra dos estudantes formandos estão apresentados na Tabela 40. No questionário aplicado aos formandos foi acrescentado um item que não consta no questionário aplicado aos ingressantes. O item é disciplinas e a decisão de não incorporar ao questionário dos ingressantes se deu por não poderem expressar impressões sobre este item, já que não começaram a freqüentar as disciplinas.

Tabela 40 - Freqüência dos valores assinalados pelos estudantes formandos com perfil empresarial dos fatores que poderiam ter auxiliado em desempenhar a atividade empresarial

\begin{tabular}{|c|c|c|c|c|c|c|c|c|c|c|c|}
\hline \multirow[b]{2}{*}{ Fator } & \multicolumn{11}{|c|}{ Valores } \\
\hline & 0 & 1 & 2 & 3 & 4 & 5 & 6 & 7 & 8 & 9 & 10 \\
\hline Disciplina & 4 & 2 & 4 & 4 & 2 & 15 & 5 & 5 & 10 & 4 & 4 \\
\hline Interação entre escola e mercado & 4 & 2 & 3 & 2 & 0 & 6 & 6 & 8 & 9 & 6 & 12 \\
\hline Interação entre professor e aluno & 7 & 1 & 6 & 6 & 2 & 12 & 6 & 6 & 5 & 4 & 3 \\
\hline $\begin{array}{l}\text { Aulas que mostrem a aplicabilidade prática dos } \\
\text { conceitos ensinados }\end{array}$ & 4 & 2 & 2 & 4 & 1 & 9 & 5 & 5 & 7 & 9 & 10 \\
\hline Estágios & 7 & 2 & 3 & 3 & 2 & 4 & 5 & 4 & 5 & 5 & 18 \\
\hline Orientação do curso & 6 & 2 & 2 & 7 & 0 & 14 & 2 & 6 & 6 & 5 & 9 \\
\hline Treinamento para lidar com mudanças & 7 & 1 & 2 & 3 & 1 & 10 & 10 & 3 & 11 & 2 & 9 \\
\hline Treinamento para lidar com risco & 4 & 1 & 2 & 1 & 2 & 13 & 5 & 5 & 9 & 7 & 10 \\
\hline
\end{tabular}

Fonte: Resultados da pesquisa

A freqüência dos valores citados pelos formandos tem uma distribuição diferente da amostra dos ingressantes. A concentração nos valores que indicam que o fator auxiliou totalmente não apresenta uma freqüência alta de valores, entretanto, os valores associados à presença do fator também não foram assinalados com grande freqüência. A tendência a responder que os fatores faltaram em grau mediano é verificada. Observa-se uma melhor distribuição das 
respostas, mas, se somados os valores associados com a ausência dos fatores, nota-se que têm maior freqüência. 


\section{CONSIDERAÇÕES FINAIS}

O empresário no início do estabelecimento das Ciências Econômicas era considerado nas análises. Neste período, tinha-se a Economia Política em que as discussões eram de caráter normativo. Com a busca de que as análises econômicas fossem positivas, tem-se no desenvolvimento do pensamento econômico uma tendência de as Ciências Econômicas tornaremse Engenharia Econômica e diversos aspectos relevantes foram excluídos das análises. Um aspecto importante que foi banido é o empresário. No período recente, com os diversos questionamentos acerca das análises do mainstream, tem-se um início da discussão do papel do empresário. Este é um vasto campo de pesquisa, que é multidisciplinar e tem muito a ser aperfeiçoado. Os aperfeiçoamentos são realizados à medida que a Economia Comportamental se desenvolve.

Neste trabalho buscou-se identificar os determinantes da preferência e da intenção de estudantes que ingressaram e terminaram seus cursos universitários em tornarem-se empresários. A partir de duas amostras de estudantes, ingressantes e formandos, foi possível identificar se há mudança na preferência e na intenção de ser empresário. Ainda, foi possível verificar quais os empecilhos para que essa preferência não esteja relacionada com a intenção. A visão dos estudantes de como o ensino superior pode ajudá-los a se tornarem empresários também é um dos resultados que foi possível analisar.

A análise dos dados revela que durante o período em que ficam no curso superior há uma mudança no gosto e na crença dos estudantes. Comparando o percentual de estudantes que ingressam no curso superior com vontade de ser empresário e o percentual de formandos que tem preferência por atividades empresariais observa-se que houve um significativo crescimento. Verifica-se que a maior parcela dos que ingressam no curso superior tem preferência por ser funcionário privado, mas durante o curso esta preferência muda. A maior parte dos formandos aprecia atividades no setor público, entretanto, há indicativos de que eles sabem das limitações do Estado em contratá-los. O grupo que aspira a ser empresário da amostra de ingressantes tem autoconfiança de que o desejo pode se tornar intenção, mas no grupo de formandos não se verifica este comportamento. Apesar do aumento entre os ingressantes e formandos do percentual com gosto por atividades empresariais, entre os formandos o confronto entre a preferência e a intenção revela que o percentual deste grupo se reduz. 
As escolas PUB - ESALQ e PRI selecionam perfis distintos de estudantes e os formandos destas escolas também são distintos. Na escola PUB - ESALQ observa-se o ingresso do perfil que gostaria de ser funcionário público em maioria, 43,6\%, enquanto o perfil empresário é o menor em participação percentual. Os formandos da escola PUB - ESALQ ainda são maioria com preferência por atividades no setor público, mas há redução destes e aumento daqueles com gosto por atividades empresariais. Desta forma, a escola PUB - ESALQ consegue, considerando-se os pressupostos do trabalho, aumentar significantemente o estoque de capital empresarial em relação à preferência, em torno de 21 pontos percentuais. Porém, quando se avalia a intenção dos estudantes formandos verifica-se que no grupo de empresários há uma redução de 11,3 pontos percentuais. Na escola PUB - ESALQ nota-se que a maioria dos estudantes acreditam que serão funcionários da iniciativa privada, mesmo que o percentual de preferência seja o menor dentre os perfis considerados. Uma hipótese sugerida para este resultado seria que a formação dada pela ESALQ é reconhecida pela iniciativa privada como sendo de excelência. Este reconhecimento facilita a inserção dos alunos no mercado como funcionários da iniciativa privada. Com respeito à escola PRI, nota-se um comportamento diferente, a atração de alunos com perfil funcionário da iniciativa privada é significativo. A atração de estudantes com perfil empresarial é superior aos atraídos pela escola PUB - ESALQ e os com perfil de funcionário público participam com menor percentual. Dentre os formandos da escola PRI, com relação ao gosto, observa-se uma redução significativa daqueles com gosto por atuar como funcionário da iniciativa privada e aumento também significativo dos com perfil de funcionário público. $\mathrm{O}$ aumento dos alunos com gosto pelo perfil empresarial aumentou em 7,2 pontos percentuais, magnitude inferior ao aumento da escola PUB - ESALQ. No entanto, na ótica de intenção observa-se que os formandos da escola PRI, apesar de desejarem ser funcionários públicos, reconhecem que o Estado não tem como empregá-los. O percentual dos que acreditam que serão empresários aumenta significativamente, em torno de 13,8 pontos percentuais. Este comportamento tem magnitude semelhante ao comportamento dos formandos da escola PUB - ESALQ, mas em sentido contrário. Se na escola PUB - ESALQ observa-se que o grupo de formandos que tem preferência por atividades empresariais aumenta durante o curso superior, com respeito à intenção deste grupo observa-se que há redução. Já na escola PRI há aumento no grupo com gosto empresarial e aumento mais que proporcional de alunos com intenção de ser empresários. Na escola PRI, o grupo com maior participação em intenção é o grupo de atividades empresariais. Desta forma, observa-se que as 
escolas aumentam o grupo com preferência por atividades empresariais, mas a escola PRI consegue que o grupo com intenção empresarial seja ainda maior. Observa-se que confrontada a preferência com a intenção dos estudantes formandos, na escola PUB - ESALQ há perda de empresários em 11,3 pontos percentuais, enquanto na escola PRI há aumento de empresários em 13,8 pontos percentuais.

As análises com relação aos fatores que influenciam na formação preferência, considerando-se o perfil, mostram-se diferentes entre os grupos. $\mathrm{Na}$ amostra de ingressante verifica-se que alguns dos fatores afetam de maneira diferente os perfis ocupacionais, enquanto para os formandos somente um fator influencia diferentemente entre os perfis. Os estudantes formandos, no caso das pessoas dos círculos de convivência, os tios, os amigos e os professores não afetam diferentemente na formação do gosto, enquanto na ótica de crença das pessoas consideradas, o pai e os avós afetam diferentemente entre os perfis. Para os alunos formandos só há diferença de influência na formação da preferência entre os perfis do aspecto orientação familiar. Cabe salientar que os professores, em nenhuma das amostras, têm papel importante na formação da preferência dos alunos. Desta forma, observam-se muitas diferenças entre formandos e ingressantes.

Com relação aos empecilhos para que a preferência não corresponda à crença entre os formandos não há diferenças entre as percepções dos perfis ocupacionais. Já para os ingressantes há diferença entre os perfis para a variável incentivo familiar. Em relação aos formandos, a análise da questão sobre o que faltou no curso superior para que facilitasse a atuação na atividade profissional desejada não indicou haver diferença entre os perfis. No entanto, a questão para os ingressantes sobre a expectativa em relação aos aspectos que os possibilitariam exercer a atividade desejada foi diferente entre os perfis. Assim, conclui-se que é necessário que o ensino tenha como preocupação atender às expectativas dos alunos, considerando-se os perfis. Isto pode ser um indicativo do porquê existir entre o grupo de formandos com gosto empresarial um percentual com descrença de que seja possível exercer a atividade desejada. A questão de autoconfiança é muito importante para o desempenho de atividades empresariais.

A análise fatorial indicou que o processo de formação da preferência entre os formandos é mais complexo. Os formandos consideram o fator maior status na formação da preferência. Ainda outra diferença é o papel das empresas juniores na formação dessa preferência. Os fatores de cunho econômico são os que apresentam maior média de importância para essa escolha. Assim, 
fica evidenciada a importância de se incorporar variáveis econômicas nos modelos que visam entender o processo de escolha por uma atividade. Outro aspecto do confronto da análise fatorial está relacionado com os professores. No grupo de ingressantes, foram agrupados no fator com menor importância média, entretanto, para os formandos, os professores passaram a participar do fator com segunda maior importância média. Assim, apesar de os professores não influenciarem os formandos de forma diferentemente entre os perfis, verifica-se que eles têm influência na preferência dos alunos por uma atividade. Desta forma, uma estratégia para aumentar o percentual dessa influência positiva na escolha e na preferência dos alunos é que os professores atuem no sentido de estimular os estudantes nesse caminho.

As limitações do estudo são principalmente relacionadas com a amostragem e os questionários. Pode-se questionar a realização de um estudo de caso em que se comparam dois grupos de pessoas distintas. O correto seria acompanhar o mesmo grupo de estudantes, mas para isso, seria necessário tempo hábil, o que não existia. Desta forma, parte-se da suposição de que a admissão via vestibular garante que o material humano seja semelhante, mas reconhece-se que se trata de uma forte suposição. O ideal é acompanhar o mesmo estudante ao longo do tempo e para validar a proposta metodológica deste estudo é ainda preciso acompanhar o estudante na sua vida para avaliar os relacionamentos entre preferência, intenção, comportamento e resultado. Em caso de um resultado falho, ainda verificar como o processo se iniciou. Quanto ao questionário, nova medidas podem e devem ser incorporadas; a parcimônia deve ser um guia, mas para uma maior consistência dos resultados é necessário aumentar o questionário. Este é um campo que está retornando às discussões econômicas; assim, a cada dia novos insights indicam a forma de aperfeiçoamento das análises. 


\section{REFERÊNCIAS}

ALBUQUERQUE, M.C.C. de. O Perfil do administrador rural: uma proposta curricular. Revista de Administração de Empresas, Rio de Janeiro, v. 25, n. 4, p. 41-48, out./dez. 1985.

ARZENI, A.; ESPOSTI, R.; SOTTE, F. Agriculture in transition countries and the european model of agriculture: entrepreneurship and multifunctionality. Ancona: Polytechnic University of Marche, 2001. 13 p. (Discussion paper on The World Bank, Šibenik-Knin and Zadar Counties: Framework for a Regional Development Vision). Disponível em:

$<$ http://www.reapbalk.unian.it/research/activities/esposti_sotte_arzeni_1.pdf > . Acesso em: 20 nov 2005

AUDRETSCH, D.B.; HEBLICH,S.; MONSEN, E.. Entrepreneurial capital. Jena, MPI. 2007. 30 p. Mimeografado.

AUDRETSCH, D.B.; KEILBACH, M. Entrepreneurship capital and economic performance. Jena: MPI, 2004 a. 24 p. (Discussion papers on Entrepreneurship, Growth and PUB - ESALQlic Policy, PUB - ESALQlicação 0104). Disponível em: < ftp://papers.mpiewjena.mpg.de/egp/discussionpapers/2004-01.pdf > . Acesso em: 20 ago 2005.

Does entrepreneurship capital matter? Entrepreneurship Theory and Practice, San Antonio, v. 28, n. 5, p. 419-429, Sept. 2004b.

AUDRETSCH, D.B.; MONSEN, E. Entrepreneurship capital: a regional, organizational, team, and individual phenomenon. Jena: MPI, 2007. 39 p. (Discussion Papers on Entrepreneurship, Growth and PUB - ESALQlic Policy, PUB - ESALQlicação 0607). Disponível em:

<ftp://papers.econ.mpg.de/egp/discussionpapers/2007-06.pdf). Acesso em: 20 maio 2007.

BAGOZZI, R.P. The poverty of economic explanations of consumption and an action theory alternative. Managerial and Decision Economics, Chichester, v. 21, p. 95-109, 2000.

BAUMOL, W.J. The entrepreneurship in economic theory. American Economic Review, Nashville, v. 58, n. 2, p. 64-71, May 1968.

BERGEVOET, R.H.M. Entrepreneurship of dutch dairy farmers. 2005. 192 p. PhD Thesis (Doutorate in Economics) - Wageningen University, Wageningen, 2005. 
BEUGELSDIJK, S.; NOORDERHAVEN, N. Personality characteristics of self-employed: an empirical study. Small Business Economics, Amsterdam, v. 24, n. 2, p. 159-167, 2005.

BIANCHI, A.M.; MURAMATSU, R. A volta de Ulisses: anotações sobre a lógica de planos e compromissos. Revista de Economia Politica, São Paulo, v. 25, n. 2, p. 23-44, 2005.

BLANCHFLOWER, D.G.; OSWALD, A. “What makes an entrepreneur?” Journal of Labor Economics, Chicago, v. 16, n. 1, p. 26-60, Jan. 1998.

BLAU, P.M.; GUSTAD, J.W.; JESSOR, R.; PARNES, H.S.; WILCOCK, R.C. Occupational choice: a conceptual framework. Industrial and Labor Relations Review, Ithaca, v. 9, n. 4, p. 531-543, July 1956.

BOETTKE, P.J.; COYNE, C.J. What role for entrepreneurship in economic development? evidence from the first, second and third world. Washington: George Mason University, 2003. (Working Paper 9). Disponível em: <http://economics.gmu.edu/pboettke/PUB ESALQs.html\#WorkPapers>. Acesso em: 20 maio 2006.

BRANDSTÄTTER, H. Becoming an entrepreneur: a question of personality structure? Journal of Economic Psychology, Amsterdam, v. 18, n.2, p. 157-177, Apr. 1997.

BRESSER-PEREIRA, L.C. O modelo Harrod-Domar e a substitutibilidade de fatores. Estudos Econômicos, São Paulo, v. 5, n. 3, p. 7-36, set. 1975. Disponível em:<www.bresserpereira.org.br/ver_file.asp?id=180>. Acesso em: 21 jun. 2007.

BROUWER, M.T. Weber, Schumpeter and Knight on entrepreneurship and economic development, Journal of Evolutionary Economics, Heidelberg, v. 12, n. 1/ 2, p. 83-105, Mar. 2002.

BYGRAVE, W.D; HOFER, C.W. Theorizing about entrepreneurship. Entrepreneurship Theory and Practice, San Antonio, v. 16, n. 4, p. 13-22, 1991.

CAMPBELL, C.A. A decision theory model for entrepreneurial acts. Entrepreneurship Theory and Practice, San Antonio, v. 17, n.1, p. 21-27, 1992.

CAMPOS, H. Estatística experimental não-paramétrica. 2.ed. Piracicaba: ESALQ, 1976. $310 \mathrm{p}$. 
CASSON, M. Entrepreneurship and the theory of the firm. Journal of Economic Behavior \& Organization, Amsterdam, v. 58, n. 2, p. 327-348, Oct. 2005.

CHAGAS, A.T.R. O questionário na pesquisa científica. Administração On Line, São Paulo, v.1, n.1, 2000. Disponível em:< http://www.fecap.br/adm_online/art11/anival.htm>. Acesso em: 28 jun. 2006.

CLEMENS, C. Social status and risk-taking in a model of occupational choice. Hannover: Universität Hannover, 2002. (Diskussionspapiere der Wirtschaftswissenschaftlichen Fakultät der Universität Hannover dp-254). Disponível em: < http://www.wiwi.uni-

hannover.de/Forschung/Diskussionspapiere/dp-254.pdf>. Acesso em: 20 maio 2005.

CORREAA, D.P.; BÊRNI, D.A. O conceito de empresário empreendedor schumpeteriano e sua atualização. Análise, Porto Alegre, v. 11, n. 2, p. 21-47, 2000.

CUEVAS, J.G; CARRASCO, F.R.C. Un modelo explicativo de la emergência de empresários.

Economia Industrial, n. 340, p. 149-162, 2001. Disponível em:

$<$ http://www.mityc.es/NR/rdonlyres/8C64804C-0AF9-4325-9675-

8A2035175B27/0/14JoaquinGuzman.pdf>. Acesso em: 30 maio 2005.

DACORSO, A.L.R. Tomada de decisão e risco: a administração da inovação em pequenas indústrias químicas. 1999. 236 p. Dissertação (Mestrado em Administração) - Faculdade De Economia, Administração e Contabilidade, Universidade de São Paulo, São Paulo, 2000.

Disponível em: <http://www.saber.usp.br>. Acesso em: 16 nov. 2005.

DAVIDSSON, P.; WIKLUND, J. Cultural values and regional variations in new firm formation. 1995. Disponível em: <http://www.babson.edu/entrep/fer/papers95/per.htm>. Acesso em: 15 set. 2006.

DJANKOV, S.; MIGUEL, E.; OIAN, Y.; ROLAND, G.; ZHURAVSKAYA, E.

Entrepreneurship: first results from Russia. Washington: World Bank, 2004. 21 p. Disponível em: <http://www1.worldbank.org/finance/assets/images/EntrepreneurshipRussia.pdf>. Acesso em: 25 ago. 2005.

DOLLINGER, M.J.; SHAW, K.N.; HARTENIAN, L.S. The older entrepreneur: an exploratory study. 2005. Disponível em: <http://www.sbaer.uca.edu/research/sbida/1988/PDF/03.pdf>. Acesso em: 02 out 2006.

DOUGLAS, E.J.; SHEPHERD, D.A. Self-employment as a career choice: attitudes, entrepreneurial intentions, and utility maximization. Entrepreneurial Theory and Practice, San Antonio, v. 26, n. 3, p. 81-90, 2002. 
DUARTE, A. Crescimento e flutuações: lição 1 - breve história da moderna teoria do crescimento econômico. Coimbra: Universidade de Coimbra. 2002. 7p. (Notas de aula). Disponível em: < http://www4.fe.uc.pt/mapsd/11_cf_0203.pdf>. Acesso em: 25 jun 2007.

EISENHAUER, J.G. The entrepreneurial decision: economic theory and empirical evidence. Entrepreneurship Theory and Practice, San Antonio, v. 19, n.4, p. 67-79, 1995.

EHRLICH, I. The mystery of human capital as engine of growth or, why the US became the economic superpower in the $\mathbf{2 0}^{\text {th }}$ century. Cambrigde: National Bureau of economic research, 2007. 40 p. (Working Paper, 12868). Disponível em: <http://www.nber.org/papers/w12868>. Acesso em: 20 fev. 2007.

ERIKSON, T. Entrepreneurial capital: the emerging venture's most important asset and competitive advantage. Journal of Business Venturing, Amsterdam, v. 17, p. 275-290, 2002.

EVANS, D.S.; JOVANOVIC, B. An estimated model of entrepreneurial choice under liquidity constraints. The Journal of Political Economy, Chicago, v. 97, n. 4, p. 808-827, Aug. 1989

EVANS, D.S.; LEIGHTON, L.S. Some empirical aspects of entrepreneurship. The American Economic Review, Nashville, v. 79, n. 3, p. 519-535, June 1989.

FERRARO, M.R. A gênese da agricultura e da silvicultura moderna no estado de São Paulo. 2005. Dissertação (Mestrado em Recursos Florestais, com opção em Conservação de Ecossistemas Florestais) - Escola Superior de Agricultura "Luiz de Queiroz", Universidade de São Paulo, Piracicaba, 2005. Disponível em: <http://www.saber.usp.br>. Acesso em: 16 maio 2002.

FILLER, R.K. The role of personality and taste in determining occupational structure. Industrial and Labor Relations Review, Ithaca, v. 39, n. 3, p. 412-424, Apr. 1986.

FIRKIN, P. Entrepreneurial capital: a resource-based conceptualisation of the entrepreneurial process. Auckland: Labour Market Dynamics Research Programme, 2001. 27 p. (Working Paper, 7). Disponível em: <http://lmd.massey.ac.nz/PUB -

ESALQlications/working\%20paper\%20no.\%207.pdf>. Acesso em: 20 mar. 2007.

FUCHS-SHÜNDELN, N. On preferences for being self-employed. 2005. Disponível em: http://www.people.fas.harvard.edu/ nfuchs/fuchs_schuendeln_preferences.pdf. Acesso em: 15 jul 2006. 
GARCÍA, F.P.; MARTÍNEZ, L.S.; SANTALUCÍA, V.M.; RADOSELOVICS, J.F.G. Measurement of social capital and growth: an economic methodology. Bilbao: Fundación BBVA, 2006. 64 p.

GREEN, R.J.; DAVID, M.D.; TYSHKOVSKY, A. The russian entrepreneur: a study of psychological characteristics, Enterprise and Innovation Management Studies, London, v. 1, n. 2, p. 187-205, 1996.

HAZELL, P.; HADDAD, L.J. Agricultural research and poverty reduction. Washington: International Food Policy Research Institute, 2001. 41 p. (Food, Agriculture and the Environment. Discussion Paper, 34). Disponível em:

$<$ http://ageconsearch.umn.edu/bitstream/123456789/19790/1/dp010034.pdf>. Acesso em: 20 fev. 2006.

IBRAHIM, G.; VYAKARNAM, S. Defining the role of the entrepreneur in economic thought: limitations of mainstream economics. Nottingham Business School. Working Paper. 2003. Disponível em: <http://www.transitions.co.uk/downloads/>. Acesso em: 20 fev. 2006.

JOHNSON, R.A.; WICHERN, D.W. Applied multivariate statistical analysis. $4^{\text {th }} \mathrm{ed}$. New Jersey: Prentice Hall. 1998. 816 p.

KING, A.G. Occupational choice, risk aversion, and wealth. Industrial \& Labor Relations Review, Ithaca, v. 27, n. 4, p. 586-596. July 1974.

KLEIN, P.G.; COOK, M.L.T.W. Schultz and the human-capital approach to entrepreneurship. Review of Agricultural Economics, Milwaukee, v. 28, n. 3, p. 344-350, 2006.

KNIGHT, F.H. Risk, uncertainty and profit. Chicago: Ed. Stigler, 1971. 447 p.

KNUDSEN, E.I.; HECKMAN, J.J.; CAMERON, J.L.; SHONKOFF, J.P. Economic, neurobiological and behavioral perspectives on building America's future workforce. Cambrigde: National Bureau of Economic Research, 2006. 26 p. (NBER Working Papers, 12298). Disponível em: <http://www.nber.org/papers/w13195>. Acesso em: 20 dez. 2006.

KRUEGER, N.F. JR The impact of prior entrepreneurial exposure on perceptions of new venture feasibility and desirability. Entrepreneurship Theory and Practice, San Antonio, v. 17, p. 5-21, 2004. 
KRUEGER, N.F. JR., REILLY, M.D., CARSRUD, A.L. Competing models of entrepreneurial intentions. Journal of Business Venturing, New York, v. 15, p. 411-432, 2000.

KON, H.C. Testing hypotheses of entrepreneurial characteristics: a study of Hong Kong MBA students. Journal of Managerial Psychology, Bradford, v. 11, n. 3, p. 12-25, 1996.

LAUWERE, C.K; ENTINGB, I.; VERMEULENC, P.; VERHAARD, K. Modern agricultural entrepreneurship. In: INTERNATIONAL CONGRESS OF FARM MANAGEMENT, 13., 2002, Arnhem. Arnhem: International Farm Management Association, 2002. Disponível em: $<$ http://www.ifmaonline.org/pdf/congress/Lauwere.pdf >. Acesso em: 21 jan. 2006.

LAZEAR, E.P. "Entrepreneurship." Journal of Labor Economics, Chicago, v. 23, n. 4, p. 649680, Oct. 2005.

LENT, R.W.; BROWN, S.D.; HACKETT, G. Toward a unifying social cognitive theory of career and academic interest, choice, and performance. Journal of Vocational Behavior, New York, v. 45, p. 79-122, 1994.

LENTZ, B.F; LABAND, D.N. Entrepreneurial success and occupational inheritance among proprietors. The Canadian Journal of Economics, Toronto, v. 23, n. 3, p. 563-579, Aug. 1990.

LITTUNEN, H. Entrepreneurship and the characteristics of the entrepreneurial personality. International Journal of Entrepreneurial Behaviour and Research, Bradford, v. 6, n. 6, p. 295-310, June 2000.

LUCAS, R.E. JR On the mechanics of economic development. The Journal of Monetary Economics, Amsterdam, v. 22, n. 1, p. 3-42, 1988.

LUMPKIN, G.T.; ERDOGAN, B. If not entrepreneurship, can psychological characteristics predict entrepreneurial orientations? a pilot study. San Diego: USASBE, 1999. 18 p.

MACHABA, R.P; LAZENBY, J.A.A. Are entrepreneurs made or born? A descriptive analysis of South African entrepreneurs. 2005. Disponível em:

<http://www.handels.gu.se/ifsam/Streams/Poster/78\%20POSTER\%20final.pdf > . Acesso em: 20 ago. 2006. 
MANKIW, N.G.; ROMER, D.; WEIL, D.N. A contribution to the empiricism of economic growth. Quarterly Journal of Economics, Cambridge, v. 107, n. 2, p. 407-437, 1992.

MARSHALL, A. Princípios de economia. Tradução de R. Almeida e O. Strauch. Rio de Janeiro: Epasa, 1946. 785 p.

MAZZAROL, T.; VOLERY, T.; DOSS, N.; THEIN V. Factors influencing small business startups: A comparison with previous research. International Journal of Entrepreneurial

Behaviour and Research, Bradford, v. 5, n. 2, p. 48-63, 1999.

MEAD, M. Growing up in New Guinea: a comparative study of primitive education. London: George Routledge, 2001. 45 p.

MEHRA, K. Entrepreneurial spirit of the Indian farmer. AI \& Society, New York, v. 16, n. 1/2, p. 112 - 118, May 2002.

NDOEN, M.L.; GORTER, C.; NIJKAMP, P.; RIETVELD, P. Ethnic entrepreneurship and migration: a survey from developing countries. 2005. (Discussion Paper, 98081). Disponível em: <http://www.tinbergen.nl/discussionpapers/98081.pdf>. Acesso em: 01 out. 2005.

OCDE: grau universitário protege contra desemprego. Deutsche Welle, São Paulo, 19 set. 2007. Disponível em: <http://www.dw-world.de/dw/article/0,,2789143,00.html>. Acesso em: 19 set. 2007.

PAULA, J.A; GAMA CERQUEIRA, H.E.A.; ALBUQUERQUE, E. M. e. Teoria econômica, empresários e metamorfoses na empresa industrial. Belo Horizonte: UFMG, Cedeplar, 2000. 23 p. (Textos para Discussão, 133).

PELAEZ, V.; SBICCA, A. Do individualismo metodológico à "racionalidade coletiva". Curitiba: UFPR, CMDE, 2000. 26 p. (Textos para Discussão, 14). Disponível em:

$<$ ww.economia.ufpr.br/PUB -

ESALQlica/textos/2000/txt1400\%20pelaez\%20e\%20sbicca\%20individualismo.doc>. Acesso em: 20 jul. 2006.

PHELPS, E. Nobel vê economia à beira da aceleração. [Entrevista a Elder Ogliari]. O Estado de S. Paulo, São Paulo, 25 abr. 2007. Disponível em: <http://clipping.planejamento.gov.br/Noticias.asp?NOTCod=350582>. Acesso em: 25 abr. 2007. 
PERES, F.C. Centro de formação de empreendedores rurais. [s.l.: s.n.]. 2005b. 10 p.

PERES, F.C.; CANZIANI, J. R. O programa de empreendorismo agroindustrial. [s.l.: s.n.]. 2005a. 15 p.

PESTANA, M.H.; GAGEIRO, J.N. Análise de dados para ciências sociais: complementaridade do SPSS. 2.ed. Lisboa: Edições Sílabo, 2000. 569 p.

POSTIGO, S.; TAMBORINI, M.F. Educación y entrepreneurship en Argentina: el caso de la universidad de San Andrés. 2005. Disponível em:

<http://www.radio10.com.ar/adjuntos/analisis/02/0000259.pdf>. Acesso em: 15 set. 2005.

PETRIN, T. Entrepreneurship as an economic force in rural development. Rome: FAO, 2005. Disponível em:

<http://www.fao.org/documents/show_cdr.asp?url_file=/DOCREP/W6882e/w6882e02.htm>. Acesso em: 25 abr. 2006.

ROBINSON, J. The production function and the theory of capital. The Review of Economic Studies, London, v. 21, n. 2, p. 81-106, 1953.

ROMER, P.M. Increasing returns and long-run growth. The Journal of Political Economy, Chicago, v. 94, n. 5, p. 1002-1037, Oct. 1986.

SANTOS, C.S. Conceito de cognição. 2007. Disponível em:

<http://drauziovarella.ig.com.br/entrevistas/claudio_memoria_2.asp>. Acesso em: 15 jul. 2007.

SCHULTZ, T.W. The value of the ability to deal with disequilibria. Journal of Economic Literatura, Nashville, v. 13, n. 3, p. 827-846, Sept. 1975.

SCHUMPETER, J.A. The theory of economic development : an inquiry into profits, capital, credit, interest, and the business cycle. Tradução de R. Opie. Cambridge: Harvard University Press, 1961. 255 p.

SIEGEL, S. Nonparametric statistics for the behavioral sciences. New York: McGraw-Hill, 1956. $312 \mathrm{p}$. 
SILVA, T. Teorias da carreira emergentes: a teoria sócio-cognitiva da carreira de Lent, Brown \& Hackett. Coimbra: Universidade de Coimbra, 2005. 14 diapositivos: color.

SKURA, D.; STATHOPOULOU S. Rural entrepreneurship and regional development. In: EUROPEAN CONGRESS EUROPEAN MONETARY UNION AND REGIONAL POLICY, 40., 2000, Barcelona. Barcelona: European Regional Science Association, 2000. Disponível em: $<$ http://www.ersa.org/ersaconfs/ersa00/pdf-ersa/pdf/166.pdf>. Acesso em: 21 jan. 2006.

SOLOW, R.M. A contribution to the theory of economic growth. Quarterly Journal of Economics, Cambridge, n. 70, p. 65-94, Feb. 1956.

Perspectives on growth theory. The Journal of Economic Perspectives, Pittsburgh, v. 8, n. 1, p. 45-54, 1994.

SONKKILA, S. Farmers' decision-making on adjustment into the EU. 2002. Academic Dissertation (Production Economics and Farm Management) - Department of Economics and Management, University of Helsinki, Helsinki, 2002. Disponível em:

<http://ethesis.helsinki.fi/julkaisut/maa/talou/vk/sonkkila/ >. Acesso em: 16 maio 2006.

TUTTLE, C.A. The entrepreneur function in economic literature. The Journal of Political Economy, Chicago, v. 35, n. 4, p.501-521, Aug. 1927

VAN DER SLUIS, J; VAN PRAAG, C.M. Economic returns to education for entrepreneurs: The development of a neglected child in the family of economics of education? Swedish Economic Policy Review, Stockholm, v. 11, p. 1-46, 2004.

VAN PRAAG, C.M. Some classic views on entrepreneurship. The Economist, Amsterdam, v. 147, n. 3, p. 311-335, Sept. 1999.

VAN PRAAG, C.M.; VAN OPHEM, H. Determinants of willingness and opportunity to start as an entrepreneur. Kyklos, Zurich, v. 48, n. 4, p. 513-540, 1995.

VOLPI, J. H. Particularidades sobre o temperamento, a personalidade e o caráter, do ponto da psicologia corporal. Curitiba: Centro Reichiano, 2004. 8 p.

WARBURTON, C. Economic terminology: factors of production and distributive shares. American Economic Review, Nashville, v. 18, n.1, p. 65-74, Mar. 1928. 
VIGNA S, D.I. Psychology and economics: evidence from the field. Cambrigde: National Bureau of Economic Research, 2007. 67 p. (Working Paper, 13420). Disponível em:

<http://www.nber.org/papers/w13420>. Acesso em: 20 Sept. 2007.

WORLD DEVELOPMENT INDICATORS. World dates. Rio de Janeiro, 2005. 1 CD-ROM. 
ANEXOS 


\section{ANEXO A - - Questionário aplicado aos estudantes ingressantes}

UNIVERSIDADE DE SÃO PAULO ESCOLA SUPERIOR DE AGRICULTURA

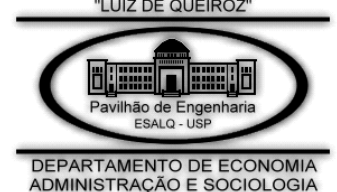

ADMINISTRACĀO E SOCIOLOGIA
A presente pesquisa acadêmica tem como objetivo aprofundar conhecimentos a respeito das expectativas de empregabilidade dos alunos da escola XXX. Este trabalho está sendo desenvolvido pela estudante de doutorado Sheila Cristina Ferreira Leite do Programa de Pós-graduação em Economia Aplicada da "Escola Superior de Agricultura Luiz de Queiroz” e tem como objetivo gerar um documento sumarizando as expectativas dos alunos da escola XXX com relação a sua ocupação profissional no futuro, em termos agregados, sem que suas opiniões individuais sejam desvendadas.

Questão 1) Sexo:
( ) Masculino
( ) Feminino

Questão 2) Em que cidade e estado você nasceu?

Questão 3) Qual é a sua idade?

Questão 4) Qual curso de graduação você freqüenta?

( ) Ciências Biológicas

( ) Ciências dos Alimentos

( ) Ciências Econômicas

( ) Engenharia Agronômica

( ) Engenharia Florestal

( ) Gestão Ambiental

Questão 5) Em que ano você iniciou este curso de graduação?

Questão 6) Qual é a sua religião?
( ) Católica
( ) Espírita
( ) Evangélica. Qual:
( ) Ateu ou agnóstica
( ) Outra. Qual:

Questão 7) Com que freqüência você vai ao templo de sua religião?
( ) Nunca
( ) Raramente
( ) De vez em quando (pelo menos 1 vez a cada mês)
( ) Frequentemente
( ) Diariamente

Questão 8) Qual é o seu estado civil?
( ) Solteiro
( ) Casado
( ) Viúvo
( ) Outro:

Questão 9) Qual é (era) a formação educacional e profissão de seus pais?

\section{Pai: Formação educacional:}

10 Grau: ( ) Completo ( ) Incompleto 2. Grau: ( ) Completo ( ) Incompleto 3ㅁau: ( ) Completo ( ) Incompleto ( ) Pós Graduação

\section{Profissão:}

Mãe: Formação educacional:

$1^{\circ}$ Grau: ( ) Completo ( ) Incompleto 2. Grau: ( ) Completo ( ) Incompleto 3o Grau: ( ) Completo ( ) Incompleto ( ) Pós Graduação

Profissão: 
Questão 10) Onde seus pais moram?

( ) Cidade de grande porte

( ) Cidade de pequeno porte

( ) Sítio ou fazenda.

( ) Outro: 
Instruções para responder a Questão 11: coloque em ordem de preferências as ocupações listadas na tabela, classificando-as de 1 até 8, "SEM REPETIR OS NÚMEROS". O número 1 representa a de maior preferência e o 8 a de menor preferência. Caso você não aceite, em hipótese alguma, qualquer uma das ocupações marque-a(s) com um $\mathbf{X}$. Observe que acredita significa o que você pensa que estará fazendo e gostaria quer dizer o que você desejaria estar fazendo considerando que pudesse optar por sua ocupação preferida.

Questão 11) Daqui a 12 anos o que você acredita que estará fazendo e o que você gostaria de estar fazendo?

\begin{tabular}{l|l|l}
\hline \multicolumn{1}{c|}{ Ocupação } & $\begin{array}{l}\text { ACREDITA que } \\
\text { estará fazendo }\end{array}$ & $\begin{array}{l}\text { GOSTARIA de } \\
\text { estar fazendo }\end{array}$ \\
\hline Trabalhando numa empresa nacional ou multinacional & & \\
\hline Trabalhando num instituto de pesquisa & & \\
\hline Trabalhando numa universidade ou escola técnica & & \\
\hline Trabalhando com assistência técnica e extensão rural & & \\
\hline Trabalhando em outra atividade do setor público & & \\
\hline Gerindo um negócio seu que não tenha sócios & & \\
\hline Gerindo negócio(s) de sua família & & \\
\hline Sócio de um negócio & & \\
\hline Outra atividade. Qual: & & \\
\hline
\end{tabular}

Instruções para responder as Questão 12, Questão 13, Questão 14 e Questão 15: dê uma nota de 0 a 10 que represente sua opinião com relação as afirmativas destas questões. A nota 0 indica que para você o fator não têm nenhum grau de importância, enquanto o valor 10 referese a um aspecto de muita importância. O campo outros deve ser utilizado caso queira colocar algum aspecto importante, mas que não conste na lista.

Questão 12) Caso o que você acredita que estará fazendo daqui a 12 anos não seja o que você gostaria de estar fazendo, quais fatores te impediriam de fazer o que gostaria?

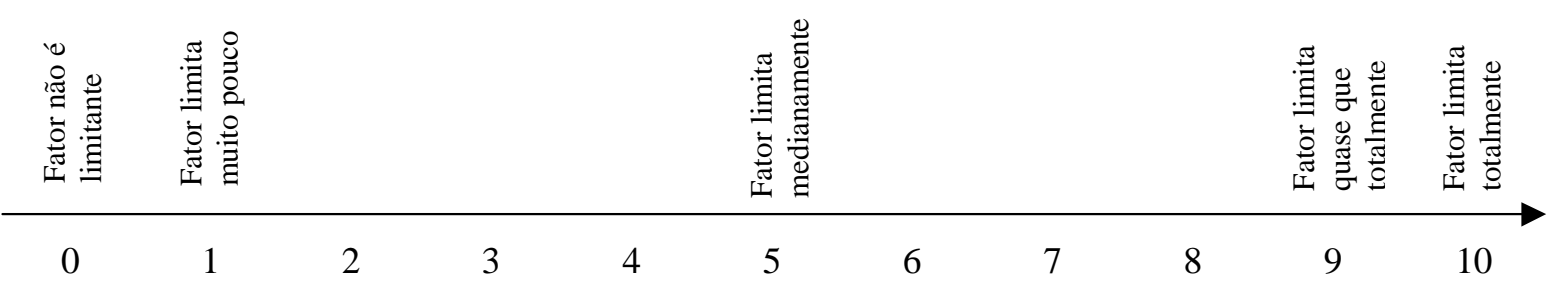

Recursos financeiros próṕprios $\begin{array}{lllllllllll}0 & 1 & 2 & 3 & 4 & 5 & 6 & 7 & 8 & 9 & 10\end{array}$

Acesso a financiamento $\quad \begin{array}{lllllllllll}0 & 1 & 2 & 3 & 4 & 5 & 6 & 7 & 8 & 9 & 10\end{array}$

\begin{tabular}{llllllllllll}
\hline Orientação familiar & 0 & 1 & 2 & 3 & 4 & 5 & 6 & 7 & 8 & 9 & 10
\end{tabular}

\begin{tabular}{llllllllllll}
\hline Treinamento formal deficiente & 0 & 1 & 2 & 3 & 4 & 5 & 6 & 7 & 8 & 9 & 10
\end{tabular}

\begin{tabular}{llllllllllll}
\hline Política econômica do país & 0 & 1 & 2 & 3 & 4 & 5 & 6 & 7 & 8 & 9 & 10
\end{tabular}

\begin{tabular}{llllllllllll}
\hline Questões institucionais do país & 0 & 1 & 2 & 3 & 4 & 5 & 6 & 7 & 8 & 9 & 10
\end{tabular}

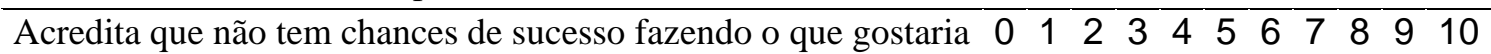

Outros: $\quad \begin{array}{lllllllllll}0 & 1 & 2 & 3 & 4 & 5 & 6 & 7 & 8 & 9 & 10\end{array}$


Questão 13) Que fatores influenciam na escolha do que você gostaria de fazer daqui a 12 anos?

\begin{tabular}{|c|c|c|c|c|c|c|c|c|c|c|c|c|c|c|c|c|c|}
\hline 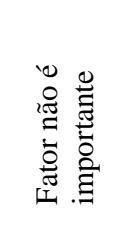 & 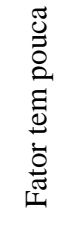 & & & & 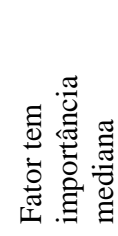 & & & & & & & & & & & 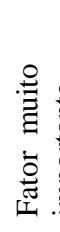 & \\
\hline 0 & 1 & 2 & 3 & 4 & 5 & 6 & & 7 & 7 & & 8 & & & 9 & & 10 & \\
\hline \multicolumn{6}{|c|}{ Maior remuneração da atividade } & & 0 & 1 & 2 & 3 & 4 & 5 & 6 & 7 & 8 & 9 & 10 \\
\hline \multicolumn{6}{|c|}{ Menos horas trabalhadas } & & 0 & 1 & 2 & 3 & 4 & 5 & 6 & 7 & 8 & 9 & 10 \\
\hline \multicolumn{6}{|c|}{ Maior estabilidade da atividade } & & 0 & 1 & 2 & 3 & 4 & 5 & 6 & 7 & 8 & 9 & 10 \\
\hline \multicolumn{6}{|c|}{ Maior status social } & & 0 & 1 & 2 & 3 & 4 & 5 & 6 & 7 & 8 & 9 & 10 \\
\hline \multicolumn{7}{|c|}{ Mais prazer proporcionado pelo cotidiano da atividade } & 0 & 1 & 2 & 3 & 4 & 5 & 6 & 7 & 8 & 9 & 10 \\
\hline \multicolumn{7}{|c|}{ Pelo incentivo da família } & 0 & 1 & 2 & 3 & 4 & 5 & 6 & 7 & 8 & 9 & 10 \\
\hline \multicolumn{7}{|c|}{ Pela orientação do curso universitário } & 0 & 1 & 2 & 3 & 4 & 5 & 6 & 7 & 8 & 9 & 10 \\
\hline \multicolumn{6}{|c|}{ Outros: } & & 0 & 1 & 2 & 3 & 4 & 5 & 6 & 7 & 8 & 9 & 10 \\
\hline
\end{tabular}

Questão 14) Em que grau as pessoas do seu círculo influenciaram na escolha do que gostaria de fazer?

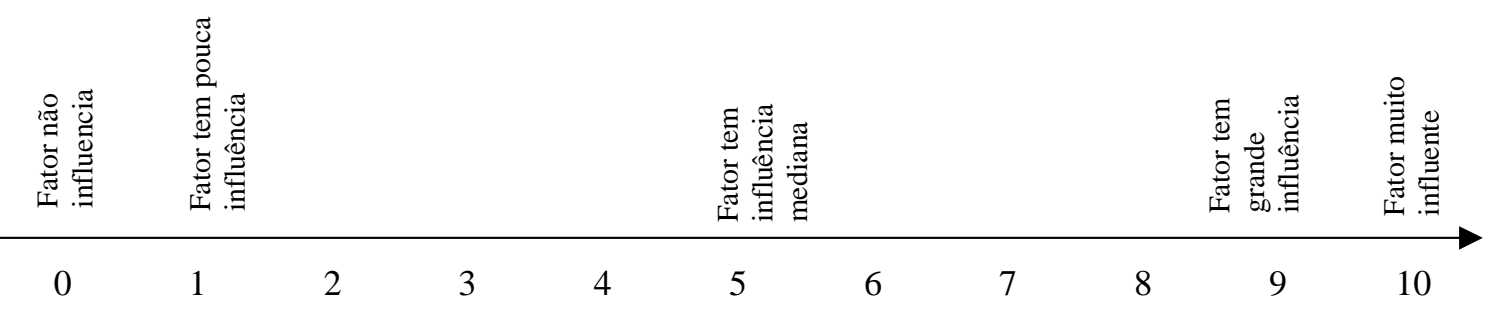

\begin{tabular}{llllllllllll} 
Pai & 0 & 1 & 2 & 3 & 4 & 5 & 6 & 7 & 8 & 9 & 10 \\
\hline Mãe & 0 & 1 & 2 & 3 & 4 & 5 & 6 & 7 & 8 & 9 & 10 \\
\hline Irmãos & 0 & 1 & 2 & 3 & 4 & 5 & 6 & 7 & 8 & 9 & 10 \\
\hline Tios & 0 & 1 & 2 & 3 & 4 & 5 & 6 & 7 & 8 & 9 & 10 \\
\hline Avós & 0 & 1 & 2 & 3 & 4 & 5 & 6 & 7 & 8 & 9 & 10 \\
\hline Amigos ou colegas & 0 & 1 & 2 & 3 & 4 & 5 & 6 & 7 & 8 & 9 & 10 \\
\hline Professores & 0 & 1 & 2 & 3 & 4 & 5 & 6 & 7 & 8 & 9 & 10 \\
\hline Outros: & 0 & 1 & 2 & 3 & 4 & 5 & 6 & 7 & 8 & 9 & 10 \\
\hline
\end{tabular}


Questão 15) O que você considera importante no seu curso universitário para auxiliá-lo na atuação do que você gostaria de estar fazendo daqui a 12 anos?

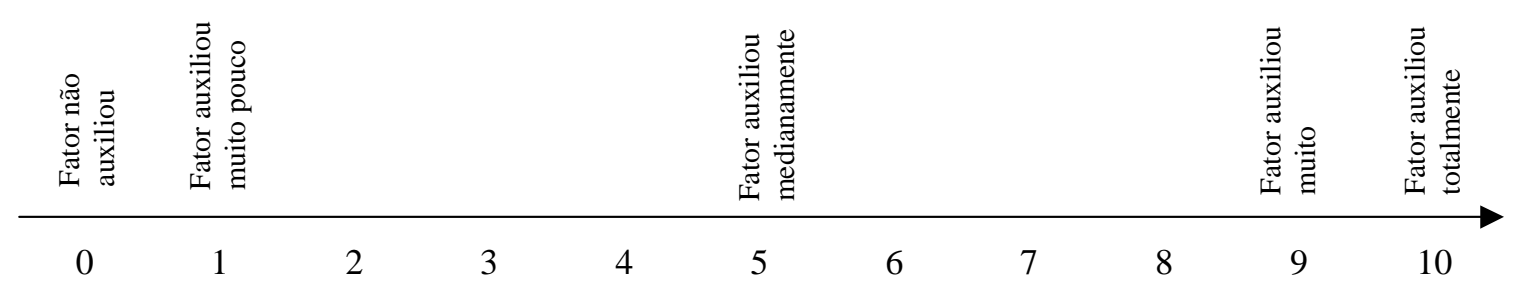

\begin{tabular}{llllllllllll}
\hline Interação entre escola e mercado & 0 & 1 & 2 & 3 & 4 & 5 & 6 & 7 & 8 & 9 & 10 \\
\hline Interação entre professor e aluno & 0 & 1 & 2 & 3 & 4 & 5 & 6 & 7 & 8 & 9 & 10 \\
\hline Aulas que mostrem a aplicabilidade prática dos & & & & & & & & & & & \\
conceitos ensinados & 0 & 1 & 2 & 3 & 4 & 5 & 6 & 7 & 8 & 9 & 10 \\
\hline Estágios & 0 & 1 & 2 & 3 & 4 & 5 & 6 & 7 & 8 & 9 & 10 \\
\hline Orientação do curso & 0 & 1 & 2 & 3 & 4 & 5 & 6 & 7 & 8 & 9 & 10 \\
\hline Treinamento para lidar com mudanças & 0 & 1 & 2 & 3 & 4 & 5 & 6 & 7 & 8 & 9 & 10 \\
\hline Treinamento para lidar com risco & 0 & 1 & 2 & 3 & 4 & 5 & 6 & 7 & 8 & 9 & 10 \\
\hline Outros: & 0 & 1 & 2 & 3 & 4 & 5 & 6 & 7 & 8 & 9 & 10 \\
\hline
\end{tabular}

Questão 16) Considere uma urna lacrada contendo 100 bolas de 2 cores:

\begin{tabular}{lcc}
\hline Bola & Probabilidade & Prêmio em R\$ \\
\hline Brancas (10 em 100) & 0,1 & $25.000,00$ (ganha) \\
Vermelhas (90 em 100) & 0,9 & 0,00 \\
\hline
\end{tabular}

Quanto você pagaria por um bilhete que te desse o direito de retirar 1 bola da caixa?

$\mathrm{R} \$$

( ) Nada, pois por princípio, não gosto de jogo.

( ) Nada, pois tenho medo de arriscar

Instrução para responder a Questão 17: considere como fonte de renda as pessoas diretamente responsáveis pelo seu sustento. Por exemplo, caso trabalhe e não receba nenhuma ajuda de sua família, a sua renda familiar corresponderá ao seu rendimento.

Questão 17) Qual a renda mensal da sua família?
( ) 01 a 04 Salários Mínimos ( De R\$350,00 até R\$1.400,00)
( ) 05 a 10 Salários Mínimos( De R\$1.401,00 até R\$3.500,00)
( ) 11 a 15 Salários Mínimos (De R\$3.501,00 até R\$ 5.250,00)
( ) 16 a 20 Salários Mínimos ( De R\$5.251,00 até R\$ 7.000,00)
( ) Mais que 20 Salários Mínimos ( mais que R\$ 7.001,00) 


\section{ANEXO B - Questionário aplicado aos estudantes formandos}

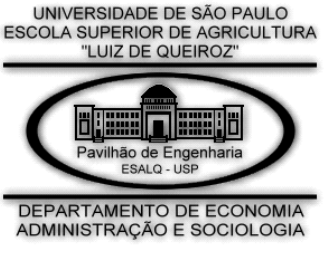

A presente pesquisa acadêmica tem como objetivo aprofundar conhecimentos a respeito das expectativas de empregabilidade dos formandos pela ESALQ. Este trabalho está sendo desenvolvido pela estudante de doutorado Sheila Cristina Ferreira Leite do Programa de Pós-graduação em Economia Aplicada da "Escola Superior de Agricultura Luiz de Queiroz" e tem como objetivo gerar um documento sumarizando as expectativas dos formandos pela ESALQ com relação a sua ocupação profissional no futuro, em termos agregados, sem que suas opiniões individuais sejam desvendadas.

Questão 18) Sexo:

( ) Masculino

( ) Feminino.

Questão 19) Em que cidade e estado você nasceu?

Questão 20) Qual é a sua idade?

Questão 21) Qual curso de graduação você freqüenta?

( ) Ciências Biológicas

( ) Ciências dos Alimentos

( ) Ciências Econômicas

( ) Engenharia Agronômica

( ) Engenharia Florestal

( ) Gestão Ambiental

Questão 22) Em que ano você iniciou este curso de graduação?

Questão 23) Qual é a sua religião?
( ) Católica
( ) Espírita
( ) Evangélica. Qual:
( ) Ateu ou agnóstica
( ) Outra. Qual:

Questão 24) Com que freqüência você vai ao templo de sua religião?
( ) Nunca
( ) Raramente
( ) De vez em quando (pelo menos 1 vez a cada mês)
( ) Frequentemente
( ) Diariamente

Questão 25) Qual é o seu estado civil?
( ) Solteiro
( ) Casado
( ) Viúvo.
( ) Outro:

Questão 26) Qual é (era) a profissão de seus pais?

Pai:

Mãe:

Questão 27) Onde seus pais moram?

( ) Cidade de grande porte 
( ) Cidade de pequeno porte

( ) Sítio ou fazenda.

( ) Outro: 
Instruções para responder a Questão 11: coloque em ordem de preferências as ocupações listadas na tabela, classificando-as de 1 até 8, SEM REPETIR OS NÚMEROS. O número 1 representa a de maior preferência e o 8 a de menor preferência. Caso você não aceite, em hipótese alguma, qualquer uma das ocupações, marque-a(s) com um $\mathbf{X}$. Observe que acredita significa o que você pensa que estará fazendo e gostaria quer dizer o que você desejaria estar fazendo considerando que pudesse optar por sua ocupação preferida.

Questão 28) Daqui a 07 anos o que você acredita que estará fazendo e o que você gostaria de estar fazendo?

\begin{tabular}{l|l|l}
\hline \multicolumn{1}{c|}{ Ocupação } & $\begin{array}{l}\text { ACREDITA que } \\
\text { estará fazendo }\end{array}$ & $\frac{\text { GOSTARIA de }}{\text { estar fazendo }}$ \\
\hline Trabalhando numa empresa nacional ou multinacional & & \\
\hline Trabalhando num instituto de pesquisa & & \\
\hline Trabalhando numa universidade ou escola técnica & & \\
\hline Trabalhando com assistência técnica e extensão rural & & \\
\hline Trabalhando em outra atividade do setor público & & \\
\hline Gerindo um negócio seu que não tenha sócios & & \\
\hline Gerindo negócio(s) de sua família & & \\
\hline Sócio de um negócio & & \\
\hline Outra atividade. Qual: & & \\
\hline
\end{tabular}

Instruções para responder as Questão 12, Questão 13, Questão 14 e Questão 15: dê uma nota de 0 a 10 que represente sua opinião com relação às afirmativas destas questões. A nota 0 indica que para você o fator não têm nenhum grau de importância, enquanto o valor 10 refere-se a um aspecto de muita importância. O campo outros deve ser utilizado caso queira colocar algum aspecto importante, mas que não conste na lista.

Questão 29) Caso o que você acredita que estará fazendo daqui a 07 anos não seja o que você gostaria de estar fazendo, quais fatores te impediriam de fazer o que gostaria?

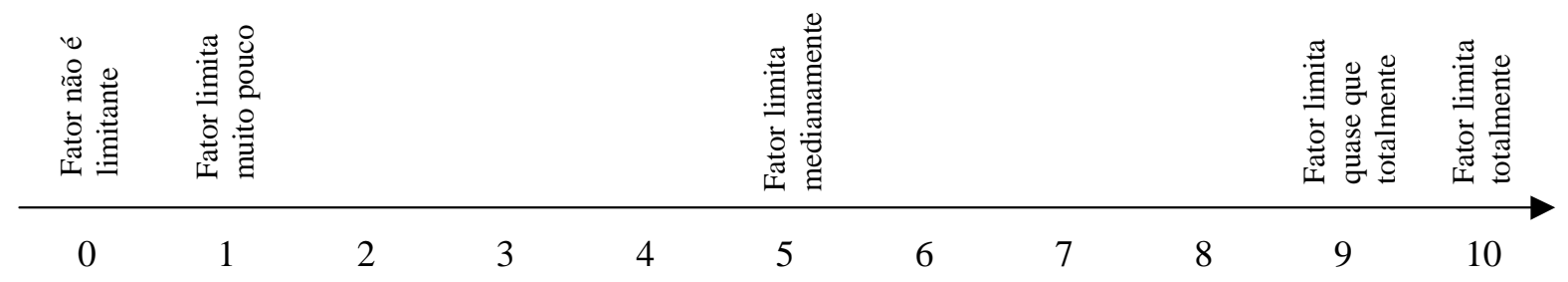

Recursos financeiros próprios $\begin{array}{lllllllllll}0 & 1 & 2 & 3 & 4 & 5 & 6 & 7 & 8 & 9 & 10\end{array}$

\begin{tabular}{llllllllllll}
\hline Acesso a financiamento & 0 & 1 & 2 & 3 & 4 & 5 & 6 & 7 & 8 & 9 & 10 \\
\hline Orientação familiar & 0 & 1 & 2 & 3 & 4 & 5 & 6 & 7 & 8 & 9 & 10 \\
\hline Treinamento formal deficiente & 0 & 1 & 2 & 3 & 4 & 5 & 6 & 7 & 8 & 9 & 10 \\
\hline Política econômica do país & 0 & 1 & 2 & 3 & 4 & 5 & 6 & 7 & 8 & 9 & 10 \\
\hline Questões institucionais do país & 0 & 1 & 2 & 3 & 4 & 5 & 6 & 7 & 8 & 9 & 10 \\
\hline Acredita que não tem chances de sucesso fazendo o que gostaria & 0 & 1 & 2 & 3 & 4 & 5 & 6 & 7 & 8 & 9 & 10 \\
\hline Outros: & 0 & 1 & 2 & 3 & 4 & 5 & 6 & 7 & 8 & 9 & 10 \\
\hline
\end{tabular}


Questão 30) Que fatores influenciam na escolha do que você gostaria de fazer daqui a 07 anos?

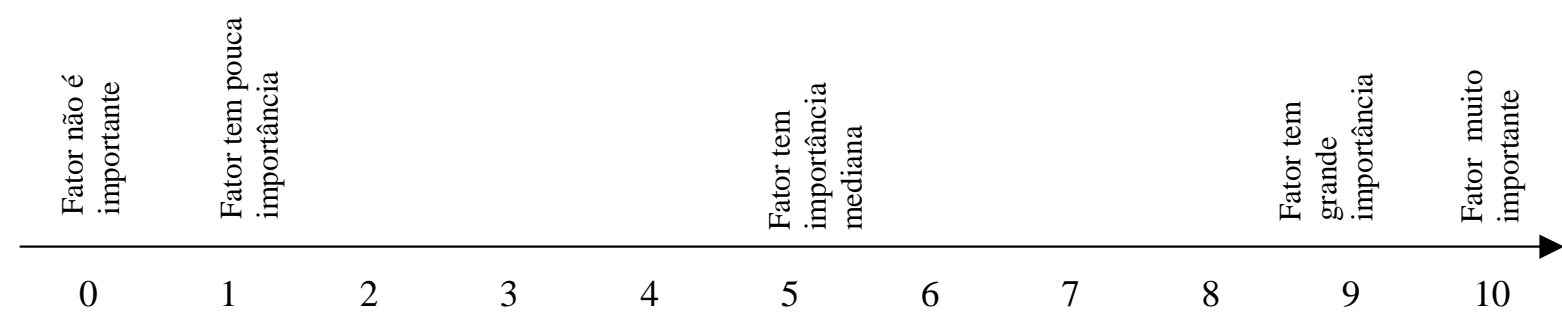

Maior remuneração da atividade $\begin{array}{lllllllllll}0 & 1 & 2 & 3 & 4 & 5 & 6 & 7 & 8 & 9 & 10\end{array}$ Menos horas trabalhadas \begin{tabular}{lllllllllll}
0 & 1 & 2 & 3 & 4 & 5 & 6 & 7 & 8 & 9 & 10 \\
\hline
\end{tabular} Maior estabilidade da atividade $\begin{array}{lllllllllll}0 & 1 & 2 & 3 & 4 & 5 & 6 & 7 & 8 & 9 & 10\end{array}$ Maior status social

Mais prazer proporcionado pelo cotidiano da atividade $\begin{array}{llllllllllll}0 & 1 & 2 & 3 & 4 & 5 & 6 & 7 & 8 & 9 & 10\end{array}$ Pelo incentivo da família $\begin{array}{lllllllllll}0 & 1 & 2 & 3 & 4 & 5 & 6 & 7 & 8 & 9 & 10\end{array}$

Pela orientação do curso universitário $\begin{array}{llllllllllll}0 & 1 & 2 & 3 & 4 & 5 & 6 & 7 & 8 & 9 & 10\end{array}$

Ter participado na empresa júnior $\begin{array}{llllllllllll}0 & 1 & 2 & 3 & 4 & 5 & 6 & 7 & 8 & 9 & 10\end{array}$

Outros: \begin{tabular}{lllllllllll}
0 & 1 & 2 & 3 & 4 & 5 & 6 & 7 & 8 & 9 & 10 \\
\hline & 1 & 2 & 3 & 4 & 5 & 6 & 7 & 8 & 9 & 10
\end{tabular}

Questão 31) Em que grau as pessoas do seu círculo influenciaram na escolha do que gostaria de fazer?

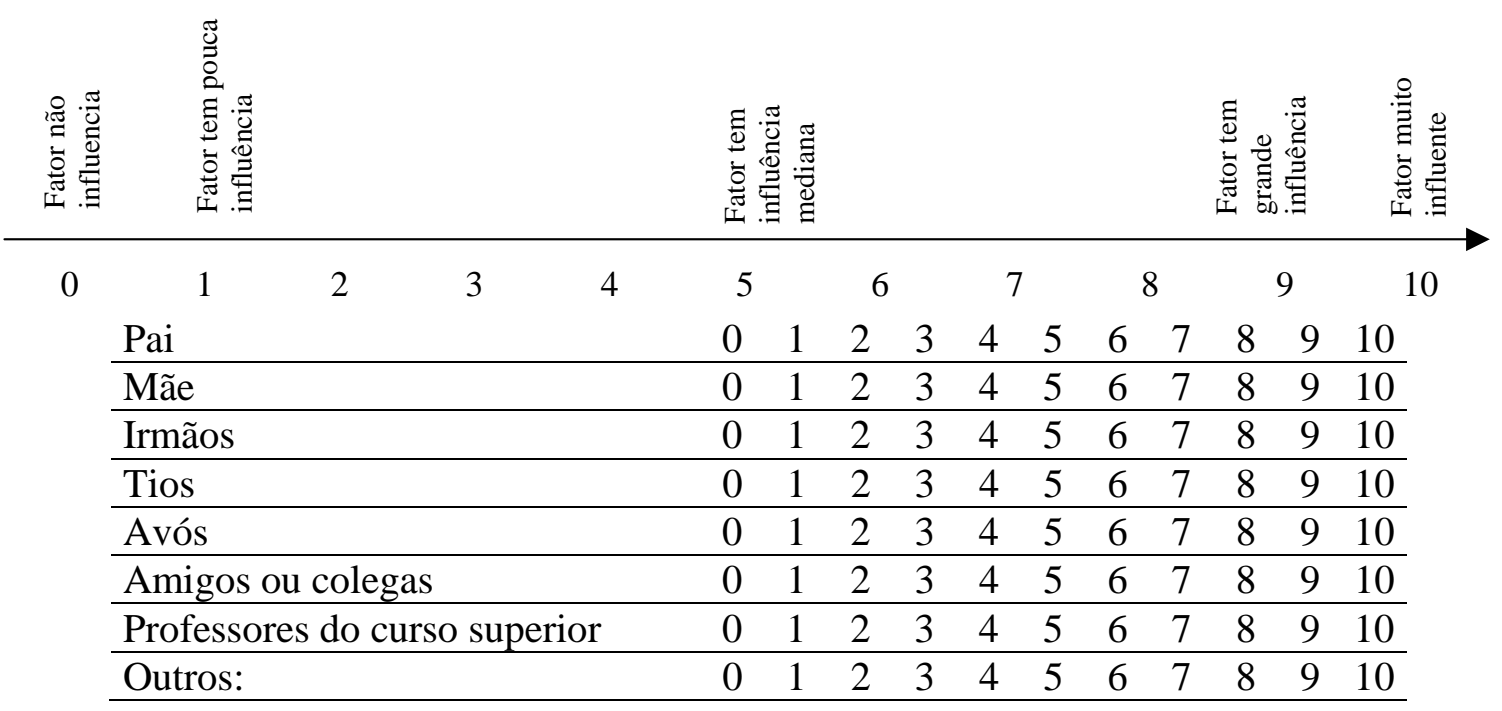


Questão 32) O que você considera que faltou no seu curso universitário que o auxiliaria para atuar no que você gostaria de estar fazendo daqui a 07 anos?

\begin{tabular}{|c|c|c|c|c|c|c|c|c|c|c|c|c|c|c|c|}
\hline 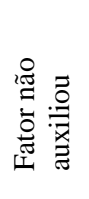 & 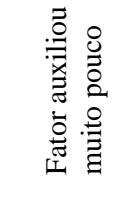 & & & & & & & & & & & & & & 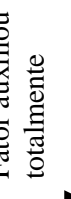 \\
\hline \multirow[t]{10}{*}{0} & 1 & 2 & 3 & 4 & 5 & 6 & & 7 & & 8 & & & 9 & & 10 \\
\hline & Discipl & & & & & & & 1 & 23 & 4 & & & 78 & & 10 \\
\hline & Maior i & çãc & es & $\mathrm{m}$ & & & 0 & 1 & 23 & 4 & 5 & & 78 & 9 & 10 \\
\hline & Maior i & ç̧̃̃o & $\mathrm{pr}$ & $\mathrm{re}$ & & & 0 & 1 & 23 & 4 & 5 & & 78 & 9 & 10 \\
\hline & $\begin{array}{l}\text { Aulas q } \\
\text { conceit }\end{array}$ & $\begin{array}{l}\text { nost } \\
\text { nsin }\end{array}$ & $\mathrm{na}$ & abil & 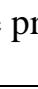 & & & 1 & 23 & 4 & 5 & 5 & 78 & 9 & 10 \\
\hline & Estágio & & & & & & & 1 & 23 & 4 & 5 & 5 & 78 & 9 & 10 \\
\hline & Orienta & do $c$ & & & & & & 1 & 23 & 4 & 5 & 3 & 78 & 9 & 10 \\
\hline & Treinan & $\mathrm{opa}$ & $\operatorname{arc}$ & nud & & & & 1 & 23 & 4 & 5 & 5 & 78 & 9 & 10 \\
\hline & Treinan & $\mathrm{opa}$ & $\operatorname{arc}$ & $\mathrm{SCO}$ & & & 0 & 1 & 23 & 4 & 5 & 5 & 78 & 9 & 10 \\
\hline & Outros: & & & & & & & 1 & 23 & 4 & 5 & 5 & 78 & 9 & 10 \\
\hline
\end{tabular}

Questão 33) Considere uma urna lacrada contendo 100 bolas de 2 cores:

\begin{tabular}{lcc}
\hline \multicolumn{1}{c}{ Bola } & Probabilidade & Prêmio em R\$ \\
\hline Brancas (10 em 100) & 0,1 & $25.000,00$ (ganha) \\
Vermelhas (90 em 100) & 0,9 & 0,00 \\
\hline
\end{tabular}

Quanto você pagaria por um bilhete que te desse o direito de retirar 1 bola da caixa?

Instrução para responder a Questão 17: considere como fonte de renda as pessoas diretamente responsáveis pelo seu sustento. Por exemplo, caso trabalhe e não receba nenhuma ajuda de sua família, a sua renda corresponderá ao seu rendimento.

Questão 34) Qual a renda mensal da sua família?

( ) 01 a 04 Salários Minímos ( De R\$350,00 até R\$1.400,00)

( ) 05 a 10 Salários Minímos ( De R\$1.401,00 até R\$ 3.500,00)

( ) 11 a 15 Salários Minímos ( De R\$3.501,00 até R\$ 5.250,00)

( ) 16 a 20 Salários Minímos ( De R\$5.251,00 até R\$ 7.000,00)

( ) Mais que 20 Salários Mínimos ( mais que R\$ 7.001,00) 